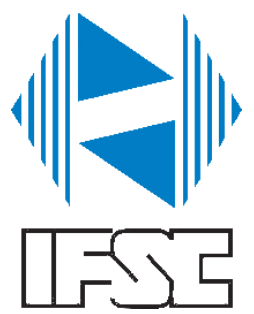

UNIVERSIDADE DE SÃO PAULO INSTITUTO DE FÍSICA DE SÃO CARLOS

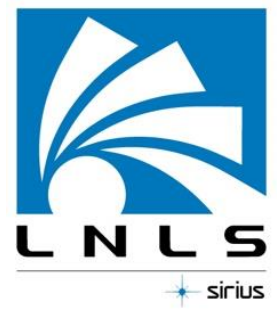

MARIA FERNANDA CERINI

Simulações ambientais e caracterização espectroscópica in situ de potenciais bioassinaturas moleculares para aplicação em missões espaciais

São Carlos

2018 



\section{Simulações ambientais e caracterização espectroscópica in situ de potenciais bioassinaturas moleculares para aplicação em missões espaciais}

Dissertação apresentada ao Programa de PósGraduação em Física do Instituto de Física de São Carlos da Universidade de São Paulo para a obtenção do título de Mestra em Ciências.

Área de Concentração: Física Aplicada Opção: Física Biomolecular

Orientador: Dr. Douglas Galante

\section{Versão Corrigida}

(versão original disponível na Unidade que aloja o Programa)

São Carlos 


\section{AUTORIZO A REPRODUÇÃO E DIVULGAÇÃO TOTAL OU PARCIAL DESTE TRABALHO, POR QUALQUER MEIO CONVENCIONAL OU ELETRÔNICO PARA FINS DE ESTUDO E PESQUISA, DESDE QUE CITADA A FONTE.}

Cerini, Maria Fernanda

Simulações ambientais e caracterização espectroscópica in situ de potenciais bioassinaturas moleculares para aplicação em missões espaciais / Maria Fernanda Cerini; orientador Douglas Galante - versão corrigida -- São Carlos, 2018.

$142 \mathrm{p}$.

Dissertação (Mestrado - Programa de Pós-Graduação em Física Aplicada Biomolecular) -- Instituto de Física de São Carlos, Universidade de São Paulo, 2018.

1. Bioassinaturas moleculares. 2. Simulações ambientais. 3. Missões espaciais. I. Galante, Douglas, orient. II. Título. 
À mulher mais linda, incrível e forte que conheço, pela qual tive a sorte de ter sido criada. Por todo o apoio e companheirismo durante os momentos bons e ruins dessa etapa da minha vida. Não estaria nem perto de onde estou se não fosse por você, mãezinha. 



\section{AGRADECIMENTOS}

Primeiramente agradeço à minha família, que sempre me ajudou muito durante todo esse começo da minha carreira acadêmica. Minha mãe, Rosaida, que sempre priorizou minha educação, me dando todo o suporte financeiro e emocional necessário; e meus irmãos, Carô e João, que, cada um de seu jeito, aguentaram meus momentos de estresse sempre me apoiando e me dando forças para continuar.

Agradeço muito ao meu orientador Douglas que, mesmo me deixando louca muitas vezes com suas milhares de ideias, foi peça essencial para minha formação, pois sempre demonstrou confiança na minha capacidade, me proporcionou muitas oportunidades e impulsionou meu desenvolvimento como pesquisadora, além da parceria e besteiras nos momentos de descontração. E ao meu co-orientador informal Fabio, que me ajudou muito tanto nas dificuldades com o projeto, sendo a melhor referência de um químico que eu tive, quanto com as "sessões terapia" nas horas de desespero, com as melhores ideias e piores piadas.

Aos colegas do LNLS, pela amizade e ajuda durante os dois anos de mestrado: em especial à Liana por alegrar meu dia-a-dia no laboratório, sempre me ajudando de todas as formas possíveis, e me apoiando nos momentos mais difíceis, tanto pessoais quanto acadêmicos. Ao Thiago pela amizade, interessantíssimas conversas, e muita ajuda nas longas noites de medidas na TGM. E ao Rodrigo, pela animação com as perguntas mais inusitadas e engraçadas que eu já respondi, e pela grande ajuda com as dificuldades em laboratório, incluindo o projeto e produção de porta-amostras para irradiação, os quais eu não conseguiria fazer sozinha.

À minha melhor amiga desde a infância, Jéssica, que sempre me acompanhou durante todo esse caminho, me dando forças para superar todos os desafios da vida com a nossa incrível amizade que, apesar da distância, nunca mudou e nunca mudará.

E ao meu amor, Felipe, pelo companheirismo, parceria, e muito amor e carinho nesses últimos meses (cruciais na elaboração desta dissertação), tornando esta etapa da minha carreira muito mais leve, e minha vida muito mais feliz.

Agradeço ao Instituto de Física de São Carlos, pela oportunidade de realização do curso de mestrado em Física Biomolecular.

À Coordenação de Aperfeiçoamento de Pessoal de Nível Superior (CAPES) e à Fundação de Amparo à Pesquisa do Estado de São Paulo (FAPESP), sob processo n ${ }^{0}$ 2016/15054-7, pelo apoio financeiro para a realização desta pesquisa com a concessão das bolsas de mestrado. 
Ao Laboratório Nacional de Luz Síncrotron (LNLS) e aos outros laboratórios do Centro Nacional de Pesquisa em Energia e Materiais (CNPEM), por colocar à disposição as instalações necessárias para a realização dos trabalhos experimentais, bem como a todos os funcionários e técnicos que fizeram os experimentos acontecerem.

Ao Laboratório Quimiosfera do Instituto de Química da Universidade de São Paulo (IQUSP/SP), sempre com grande ajuda do Evandro, Gabriel Araújo e Gabriel Gonçalves, durante os experimentos na Câmara de Simulações Espaciais e Planetárias (AstroCam).

Ao Laboratório de Espectroscopia Molecular do Instituto de Química da USP (LEM - IQ/USP), pela disponibilidade de equipamentos espectroscópicos.

E, por fim, agradeço imensamente ao Núcleo de Pesquisa em Astrobiologia (NAP/Astrobio), pela oportunidade de conhecer e se envolver com esta incrível área de pesquisa. 
"Em algum lugar, algo INCRÍVEL está esperando para ser descoberto."

Carl Sagan

"A mente que se abre a uma nova ideia jamais volta ao seu tamanho original."

Albert Einstein 



\section{RESUMO}

CERINI, M. F. Simulações ambientais e caracterização espectroscópica in situ de potenciais bioassinaturas moleculares para aplicação em missões espaciais. 2018. 142 p. Dissertação (Mestrado em Ciências) - Instituto de Física de São Carlos, Universidade de São Paulo, São Carlos, 2018.

A Astrobiologia é uma área de pesquisa crescente no Brasil, na qual se estuda o fenômeno da vida no Universo. Um de seus subtemas estuda as bioassinaturas: substâncias que evidenciam da presença de vida, passada ou presente. Foram investigadas em laboratório a detectabilidade de biomoléculas, que são potenciais bioassinaturas moleculares, e a fotoestabilidade de suas assinaturas espectroscópicas em ambientes extraterrestres simulados. Os experimentos foram baseados em irradiações no ultravioleta, que é a principal faixa da radiação solar responsável pela evolução e degradação de moléculas orgânicas em ambientes espaciais. Um maior foco foi dado aos pigmentos biológicos $\beta$-caroteno e clorofila a, os quais foram irradiados puros e/ou misturados a diferentes substratos inorgânicos, mimetizando superfícies de planetas rochosos, satélites e asteroides. Foram utilizadas as instalações do Laboratório Nacional de Luz Síncrotron (LNLS), em especial a linha de luz TGM, na faixa do UV, VUV e EUV, e também lâmpadas de baixa pressão que emitem na faixa do UVC. Na Câmara de Simulação Espacial e Planetária (AstroCam), do Núcleo de Pesquisa em Astrobiologia da USP (NAP/Astrobio), diversos parâmetros ambientais foram controlados para simular as condições da superfície de Marte. E balões de alta-altitude foram utilizados para testar a resposta de biomoléculas na estratosfera, cujas condições são similares às da superfície marciana, além de validar experimentos que podem ser enviados em missões espaciais. As mudanças nas respostas espectroscópicas das biomoléculas foram medidas por absorbância no UV-Vis e no IR e por espalhamento Raman, algumas in situ e em tempo real e outras ex situ. As técnicas provaram ser adequadas para esses estudos pois forneceram informações sobre as fotoestabilidades das respostas espectroscópicas das biomoléculas, permitindo testar seus potenciais como bioassinaturas em diferentes superfícies do Sistema Solar. Os resultados também podem contribuir para missões espaciais, dando suporte ao desenvolvimento e otimização de técnicas e procedimentos para estudar os efeitos da exposição de biomoléculas a ambientes espaciais reais - em missões de pequeno porte e baixo custo, como CubeSats -, e até mesmo para a detecção de bioassinaturas em superfícies planetárias extraterrestres.

Palavras-chave: Bioassinaturas moleculares. Simulações ambientais. Missões espaciais. 



\begin{abstract}
CERINI. M. F. Environmental simulations and spectroscopic in situ characterization of potential molecular biosignatures for application in space missions. 2018. 142 p. Dissertação (Mestrado em Ciências) - Instituto de Física de São Carlos, Universidade de São Paulo, São Carlos, 2018.
\end{abstract}

Astrobiology is a growing research area Brazil, which studies the phenomenon of life in the Universe. One of its sub-themes studies biosignatures: substances which evidence the presence of life, past or present. The detectability of biomolecules, which are potential molecular biosignatures, and the photostability of their spectroscopic signatures in simulated extraterrestrial environments were investigated in laboratory. The experiments were based on irradiations in the ultraviolet, which is the main range of solar radiation responsible for the evolution and degradation of organic molecules in space environments. The research was focused in the biological pigments $\beta$-carotene and chlorophyll a, which were irradiated in both pure form and/or mixed with different inorganic substrates, mimicking the surfaces of rocky planets, satellites and asteroids. The facilities of the Brazilian Synchrotron Light Laboratory (LNLS) were used, especially the TGM beamline in the UV, VUV and EUV range, as well as low pressure lamps emitting in the UVC range. In the Space and Planetary Simulation Chamber (AstroCam) of the Astrobiology Research Unit of USP, several environmental parameters were controlled to simulate the surface conditions of Mars. And high-altitude balloons were used to test the response of biomolecules in the stratosphere, where the conditions are similar to those of the Martian surface, in addition to validate experiments which can be sent in space missions. Changes in the biomolecules' spectroscopic responses were measured by UV-Vis and IR absorbance and by Raman scattering, either in situ and in real time or ex situ. The techniques proved to be adequate for these studies, since they provided information on the photostability of the biomolecules' spectroscopic responses, allowing the testing of their potential as biosignatures on different surfaces of the Solar System. The results can also contribute to space missions, supporting the development and optimization of techniques and procedures, both for the exposure of biomolecules to real space environments - in small and low-cost missions, such as CubeSats -, as well as for the actual detection of biosignatures on extraterrestrial planetary surfaces.

Keywords: Molecular biosignatures. Environmental simulations. Space missions. 



\section{LISTA DE FIGURAS}

Figura 1 - Estruturas químicas dos pigmentos clorofila a (esquerda) e $\beta$-caroteno (direita) 26

Figura 2 - Espectro no infravermelho do pigmento $\beta$-caroteno em pó, em disco de $\mathrm{KBr}$.

Figura 3 - Espectro no infravermelho (FTIR) do pigmento clorofila a, extraída da planta absinto (Artemisia absinthium).

Figura 4 - Espectro Raman do pigmento $\beta$-caroteno (laser $785 \mathrm{~nm}$ ). 28

Figura 5 - Espectros de absorção no UV-Vis do pigmento $\beta$-caroteno, em três formas isoméricas diferentes (trans, 9-cis e 15-cis).

Figura 6 - Espectros de absorção no UV-Vis do pigmento $\beta$-caroteno (trans), em dois solventes diferentes (hexano e etanol).

Figura 7 - Espectros de absorção no UV-Vis dos pigmentos clorofila a e b em éter (esquerda) e complexadas em proteínas do fotossistema II (PSII RC) e de captação de luz (LHC) (direita).

Figura 8 - Substratos inorgânicos utilizados nos experimentos. Cima para baixo: as argilas montmorilonita $\left(\mathrm{SY}_{\mathrm{n}-1}\right)$ e caulinita $\left(\mathrm{KG}_{\mathrm{a}-2}\right)$, e os simulantes dos regolitos de Marte (JSC Mars-1A) e da Lua (JSC-1A).

Figura 9 - Espectro eletromagnético e as principais faixas de interação da radiação com a matéria. Onde UV = ultravioleta, VIS = visível, IV = infravermelho, VUV = ultravioleta de vácuo, $\mathrm{EUV}=$ ultravioleta extremo e $\mathrm{THz}=$ terahertz.

Figura 10 - Esquema geral de um acelerador fonte de luz síncrotron. 36

Figura 11 - Vista superior do anel de armazenamento de elétrons, fonte de luz síncrotron, do LNLS (UVX) e de suas estações experimentais. 36

Figura 12 - Fluxo da radiação síncrotron no LNLS em função da energia dos fótons 38

Figura 13 - Diagrama de energia mostrando a transição vibracional pela absorção de luz policromática no infravermelho. 46

Figura 14 - Esquema de funcionamento de um equipamento FTIR. 48

Figura 15 - Esquerda: Interferograma típico obtido em equipamento FTIR. Direita: espectro IR obtido após transformada de Fourier.

Figura 16 - Diagrama de energia mostrando a transição vibracional envolvida na espectroscopia Raman.

Figura 17 - Diagramas de energia dos estados envolvidos nos espalhamentos elástico (Rayleigh) e inelásticos (Stokes e anti-Stokes).

Figura 18 - Espectro Raman do cromato de chumbo (PbCrO4) obtido com laser de 514,5 nm. Comparação entre as linhas Stokes e Anti-Stokes, com intensidades diferentes e o mesmo 
valor de deslocamento Raman em módulo. Três escalas adicionais acima para elucidar a relação entre número de onda absoluto e relativo, frequências e comprimento de onda. .52

Figura 19 - Diagrama de energia mostrando a transição vibrônica pela absorção de luz policromática no UV-vis.

Figura 20 - Reflexões especular (esquerda) e difusa (direita) 54

Figura 21 - Esquerda: foto do pastilhador de $13 \mathrm{~mm}$ (cima) e almofariz + pistilo de porcelana (baixo). Direita: foto da prensa manual utilizada para produzir as pastilhas. 60

Figura 22 - Esquerda: esquema de produção dos filmes. Direita: aerógrafo em detalhe. 61

Figura 23 - Equipamentos de bancada no modo de transmissão utilizados na caracterização dos filmes finos irradiados. Esquerda: FTIR. Direita: UV-Vis.

Figura 24 - Filmes das amostras dentro da caixa de irradiação contendo duas lâmpadas germicidas (UVC), apagadas (esquerda) e acesas (direita).

Figura 25 - Foto da Câmara de Simulação de Ambientes Espaciais e Planetários (AstroCam) em funcionamento (esquerda) e do Simulador Solar desacoplado dela (direita).

Figura 26 - Foto da parte de dentro da câmara da AstroCam mostrando o setup montado para as medidas de reflectância in situ utilizando uma sonda de reflectância.

Figura 27 - Esquerda: porta-amostras de alumínio com pastilhas das amostras de $\beta$-caroteno. Centro: porta-amostras de alumínio com pastilhas das amostras de Clorofila a. Direita: feixe de luz síncrotron irradiando uma das amostras dentro da câmara experimental da TGM.

Figura 28 - Esquema da análise in situ por reflectância no UV-vis da degradação por irradiação com radiação síncrotron, feita na estação experimental da linha de luz TGM.

Figura 29 - Esquerda: espectrômetro micro-Raman disponível no LNLS. Direita: detalhe do interior do equipamento.

Figura 30 - a- Preparo do balão estratosférico para voo carregando a sonda Garatéa I (São Carlos$\mathrm{SP})$. b- Sonda Garatéa, a $32 \mathrm{~km}$ de altitude, expondo as amostras às condições estratosféricas.

Figura 31 - Porta amostras utilizado na Garatéa-I aberto com as amostras depositadas em alumínio (quadrados mais claros), e silício (quadrados mais escuros).

Figura 32 - Sonda da missão Garatéa-II em sua máxima altitude, expondo as amostras às condições estratosféricas.

Figura 33 - Porta amostras utilizado na Garatéa-II aberto com as amostras em pó (esquerda), fechado e vedado (meio), e detalhe das peças separadas (direita).

Figura 34 - Espectros FTIR (modo ATR) obtidos das amostras de $\beta$-caroteno puro e natural (da cenoura) em pó.

Figura 35 - Espectros FTIR (modo ATR) obtidos da amostra de clorofila a natural (Spirulina) e seu extrato em etanol. 
Figura 36 - Estruturas químicas dos derivados do $\beta$-caroteno, retinal (esquerda) e retinol (direita)... 78

Figura 37 - Espectro Raman obtidos das amostras de $\beta$-caroteno puro e natural (da cenoura) em pó, com laser de $785 \mathrm{~nm}$.

Figura 38 - Espectros de absorção no UV-Vis obtidos das amostras de $\beta$-caroteno puro e natural (da cenoura), por transmitância e por reflectância. Eixos y normalizados (unidades arbitrárias).

Figura 39 - Espectros de absorção no UV-Vis obtidos por transmitância das amostras de clorofila a natural (Spirulina) e seu extrato em etanol.

Figura 40 - Fotos dos filmes de pigmentos biológicos (laranja: $\beta$-caroteno e verde: Clorofila a) obtidas em cada intervalo de tempo durante as irradiações com luz UVC.

Figura 41 - Espectros de absorbância no IR obtidos durante as irradiações com luz UVC de filmes de clorofila a

Figura 42 - Espectros de absorbância no IR obtidos durante as irradiações com luz UVC de um filme de $\beta$-caroteno.

Figura 43 - Espectros de absorbância no UV-vis obtidos durante as irradiações com luz UVC de um filme de Clorofila a

Figura 44 - Espectros de absorbância no UV-vis obtidos durante as irradiações com luz UVC de filmes de $\beta$-caroteno.

Figura 45 - Esquema de cálculo da intensidade das bandas, utilizando como exemplo uma das bandas da clorofila a (centrada em $\sim 660 \mathrm{~nm}$ )

Figura 46 - Intensidade da banda em $420 \mathrm{~nm}$ das 3 replicatas (1c, 2c e 3c) da clorofila a em relação à intensidade máxima em função do tempo de irradiação com luz UVC, e ajustes polinomiais das curvas. 90

Figura 47 - Intensidade da banda em $660 \mathrm{~nm}$ das 3 replicatas (1c, 2c e 3c) da clorofila a em relação à intensidade máxima em função do tempo de irradiação com luz UVC, e ajustes polinomiais das curvas.

Figura 48 - Intensidade da banda em 462 nm em 3 replicatas (1b, 2b e 3b) do $\beta$-caroteno em relação à intensidade máxima, em função do tempo de irradiação com luz UVC, e ajustes exponenciais das curvas.

Figura 49 - Espectros obtidos no UV-vis do $\beta$-caroteno irradiado na AstroCam em simulação da superfície marciana.

Figura 50 - Intensidade das bandas do $\beta$-caroteno, em 462 e 494 nm, em relação à intensidade máxima, em função do tempo de irradiação na AstroCam, e ajustes exponenciais das curvas.

Figura 51 - Irradiância da radiação solar que chega na superfície terrestre, em função do comprimento de onda, de acordo com o modelo SOLAR2000.

Figura 52- Gráficos da refletividade de um espelho de Pt em função da energia do fóton incidente. . 96 
Figura 53 - Medidas de corrente do feixe síncrotron pelo fotodiodo utilizado.

Figura 54 - Eficiência quântica (ou responsividade) do fotodiodo em função da energia do fóton..... 98

Figura 55 - Esquerda: porta-amostras com pastilhas das amostras de $\beta$-caroteno após a irradiação total. Direita: porta-amostras com pastilhas das amostras de Clorofila a após a irradiação total.

Figura 56 - Espectros de reflectância no UV-vis obtidos durante as irradiações com luz síncrotron de filmes de clorofila a. 100

Figura 57 - Espectros de reflectância no UV-vis obtidos durante as irradiações com luz síncrotron de filmes de $\beta$-caroteno. 101

Figura 58 - Intensidade das bandas em $\sim 435 \mathrm{e} \sim 667 \mathrm{~nm}$ da clorofila a em relação à intensidade máxima, em função da fluência de radiação síncrotron.

Figura 59 - Intensidade das bandas em $\sim 483 \mathrm{~nm}$ do $\beta$-caroteno em relação à intensidade máxima, em função da fluência de radiação síncrotron.

Figura 60 - Intensidade das bandas em $\sim 435 \mathrm{e} \sim 667 \mathrm{~nm}$ da clorofila a e em $\sim 483 \mathrm{~nm}$ do $\beta$-caroteno em relação à intensidade máxima, em função da fluência de radiação síncrotron, com cada substrato.

Figura 61 - Ajuste exponencial da curva de decaimento completa da amostra de $\beta$-caroteno com o solo lunar.

Figura 62 - Ajustes exponenciais das curvas de decaimento de 3 fases de degradação da amostra de $\beta$ caroteno com o solo lunar. 107

Figura 63 - Comparação entre os tempos necessários para extinguir as bandas em $\sim 430$ e $\sim 667 \mathrm{~nm}$ da clorofila a e em $\sim 485 \mathrm{~nm}$ do $\beta$-caroteno, puras e com cada um dos substratos, expostas na superfície de Marte. 108

Figura 64 - Espectros Raman obtidos antes e após a irradiação de 1 hora da amostra de $\beta$-caroteno com o solo lunar.

Figura 65 - Intensidades dos picos do $\beta$-caroteno em função da fluência de radiação síncrotron...... 110

Figura 66 - Espectro Raman de $\beta$-caroteno nas 3 condições experimentais: exposta à radiação, não exposta à radiação e controle em Terra. As curvas não estão normalizadas.

Figura 67 - Espectro Raman dos pigmentos extraídos da D. radiodurans nas 3 condições experimentais: exposta à radiação, não exposta à radiação e controle em Terra. As curvas não estão normalizadas.

Figura 68 - Espectros Raman da DL-cisteína nas 3 condições experimentais: exposta à radiação, não exposta à radiação e controle em Terra.

Figura 69 - Espectros Raman do $\beta$-caroteno e da bactéria Deinoccocus radiodurans nas 3 condições experimentais: exposta à radiação $(\mathrm{E})$, não exposta à radiação $(\mathrm{N})$ e controle em Terra $(\mathrm{C})$. 
Figura 70 - Área por intensidade dos picos da ponte dissulfeto em diferentes amostras.

Figura 71 - Área por intensidade dos picos do $\beta$-caroteno.

Figura 72 - Área por intensidade dos picos do carotenoide presente na bactéria Deinoccocus Radiodurans

Figura 73 - Esquerda: Design proposto para a Garatéa-L. Direita: Possível esquema para análise das amostras no CubeSat, baseado em reflectância difusa.

Figura 74 - Monitoramento do comportamento da lâmpada do simulador solar da AstroCam.

Figura 75 - Irradiação do branco sulfato de bário $\left(\mathrm{BaSO}_{4}\right)$ com o simulador solar da AstroCam..... 133

Figura 76 - Espectros de reflectância no UV-Vis obtidos durante as irradiações com luz síncrotron de filmes de $\beta$-caroteno.

Figura 77 - Espectros Raman da guanina nas 3 condições experimentais: exposta à radiação, não exposta à radiação e controle em Terra.

Figura 78 - Espectros Raman da fulereno $\mathrm{C}_{60}$ nas 3 condições experimentais: exposta à radiação, não exposta à radiação e controle em Terra.

Figura 79 - Espectros Raman da hemina nas 3 condições experimentais: exposta à radiação, não exposta à radiação e controle em Terra.

Figura 80 - Espectros Raman do ATP nas 3 condições experimentais: exposta à radiação, não exposta à radiação e controle em Terra.

Figura 81 - Espectros Raman do ácido fumárico nas 3 condições experimentais: exposta à radiação, não exposta à radiação e controle em Terra.

Figura 82 - Espectros Raman da L-cistina nas 3 condições experimentais: exposta à radiação, não exposta à radiação e controle em Terra

Figura 83 - Espectros Raman da DL-cisteína misturada com o solo simulante do regolito de Marte nas 3 condições experimentais: exposta à radiação, não exposta à radiação e controle em Terra.

Figura 84 - Espectros Raman da DL-cisteína misturada com a argila montmorilonita nas 3 condições experimentais: exposta à radiação, não exposta à radiação e controle em Terra.

Figura 85 - Espectros Raman da DL-cisteína misturada com a argila caulinita nas 3 condições experimentais: exposta à radiação, não exposta à radiação e controle em Terra.....

Figura 86 - Espectros Raman da DL-cisteína misturada com o hidroxi-oxido de ferro goetita nas 3 condições experimentais: exposta à radiação, não exposta à radiação e controle em Terra.

Figura 87 - Espectros Raman da DL-cisteína misturada com nas 3 condições experimentais: exposta à radiação, não exposta à radiação e controle em Terra. 



\section{LISTA DE TABELAS}

Tabela 1 - Composição dos regolitos simulados do solo lunar e marciano, e composição real do solo lunar.

Tabela 2 - Missões espaciais sobre a evolução da matéria orgânica e resumo dos resultados... 40

Tabela 3 - Amostras utilizadas em todos experimentos, suas classes e fornecimento.

Tabela 4 - Comparação entre as condições ambientais da superfície de Marte e das atingidas em simulação na AstroCam.

Tabela 5 - Concentrações utilizadas no preparo das pastilhas para irradiação na linha TGM. .. 67

Tabela 6 - Comparação entre as condições ambientais da estratosfera terrestre, entre 12 e 25 $\mathrm{km}$ acima do nível do mar, e da superfície de Marte.

Tabela 7 - Misturas de amostras utilizadas no experimento de simulação em ambiente estratosférico.

Tabela 8 - Identificação dos picos do espectro de infravermelho do $\beta$-caroteno.

Tabela 9 - Identificação dos picos do espectro de infravermelho da clorofila a.

Tabela 10 - Identificação dos picos do espectro Raman do $\beta$-caroteno.

Tabela 11 - Posições dos picos dos espectros de absorbância no UV-Vis das amostras de $\beta$ caroteno.

Tabela 12 - Posições dos picos dos espectros de absorbância no UV-Vis das amostras de Spirulina pura e seu extrato em etanol.

Tabela 13 - Espessuras dos filmes de $\beta$-caroteno e clorofila a (Spirulina) 84 



\section{SUMÁRIO}

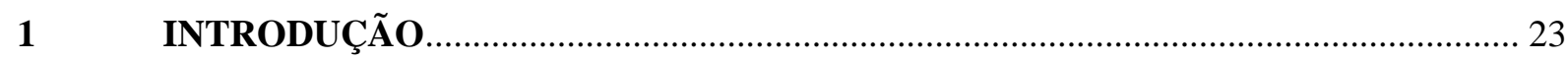

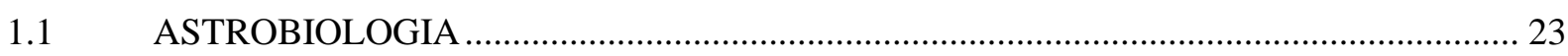

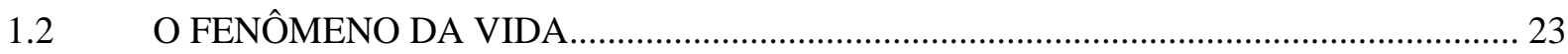

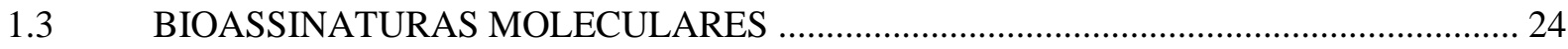

1.3.1 Potenciais bioassinaturas moleculares e sua detecção ................................................. 25

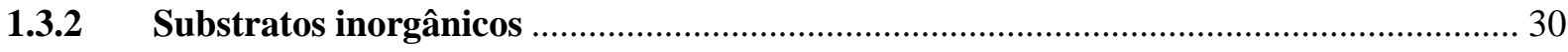

1.4 INTERAÇÃO DA RADIAÇÃO COM A MATÉRIA: radiação ultravioleta ......................... 32

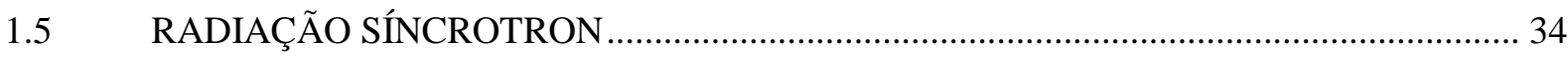

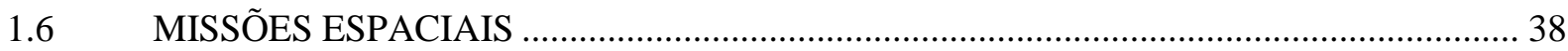

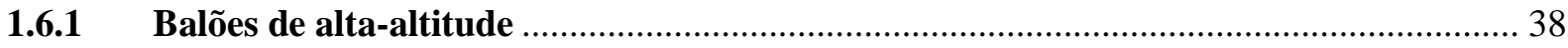

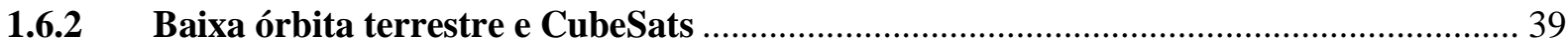

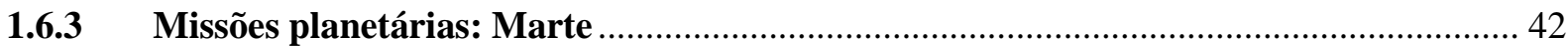

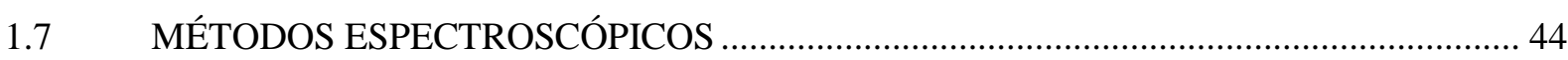

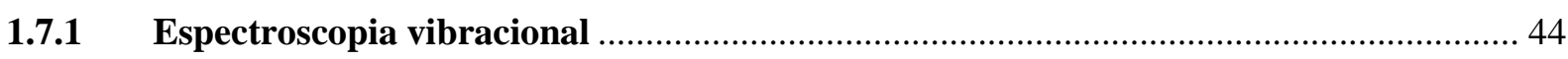

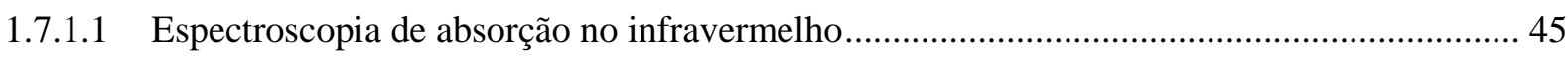

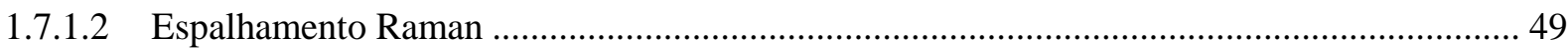

1.7.2 Espectroscopia Eletrônica no ultravioleta-visível ........................................................ 53

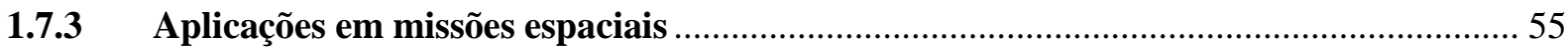

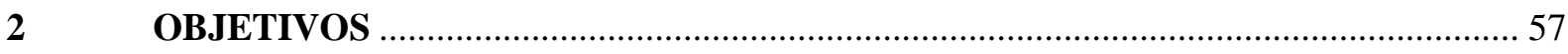

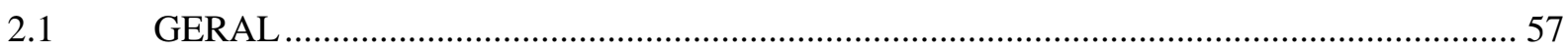

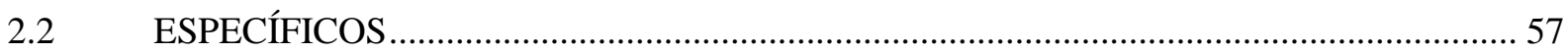

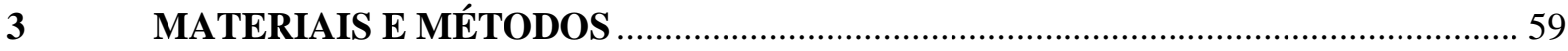

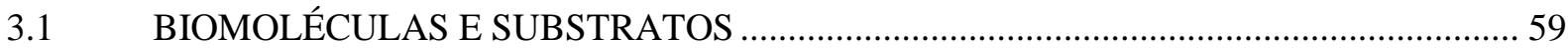

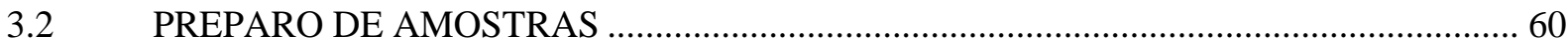

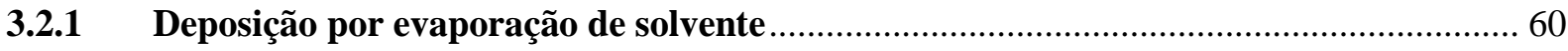

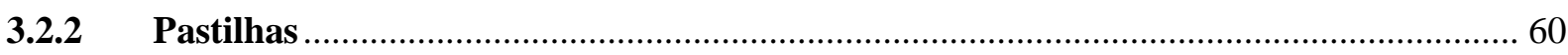

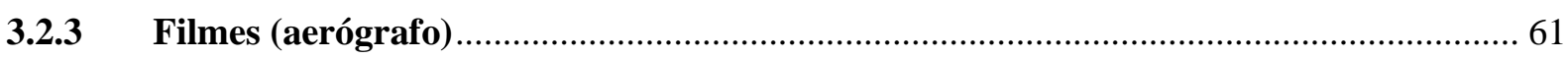

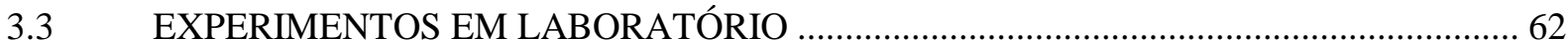

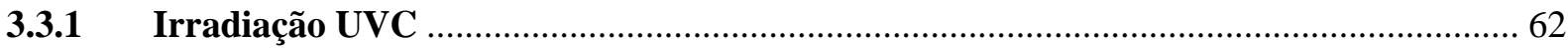

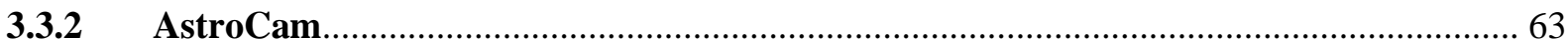

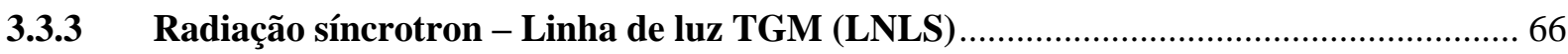

3.4 EXPERIMENTOS NA ESTRATOSFERA: BALÕES DE ALTA-ALTITUDE ................... 69

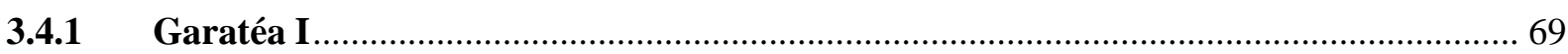

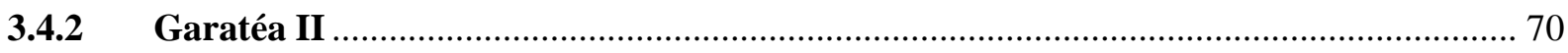

$4 \quad$ RESULTADOS E DISCUSSÃO 
4.1 DETECTABILIDADE ESPECTROSCÓPICA DAS AMOSTRAS DE INTERESSE ......... 75

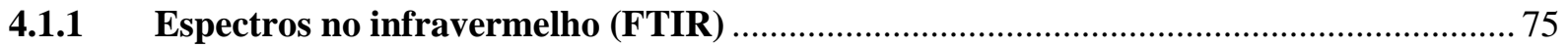

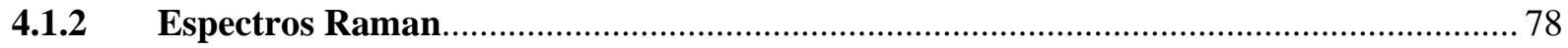

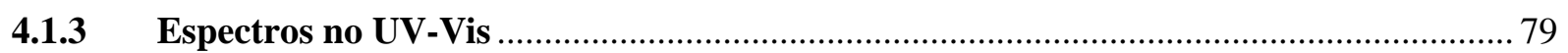

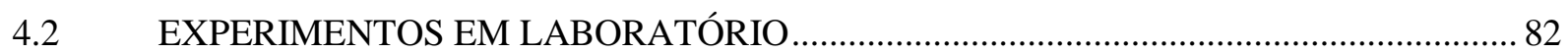

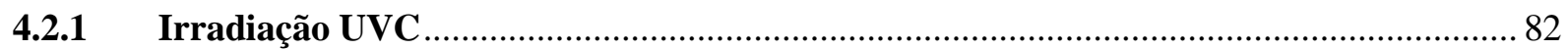

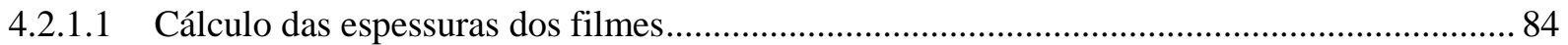

4.2.1.2 Medida dos efeitos da irradiação por absorção no IR ........................................................... 84

4.2.1.3 Medida dos efeitos da irradiação por absorção no UV-Vis ................................................... 86

4.2.1.4 Análise dos limites de detecção - espectros de absorbância no UV-Vis ................................. 88

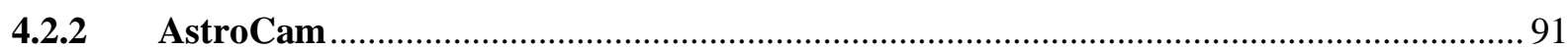

4.2.2.1 Medida dos efeitos da irradiação por reflectância no UV-Vis .............................................. 91

4.2.2.2 Análise dos limites de detecção - espectros de reflectância no UV-Vis................................. 92

4.2.2.3 Comparando com a radiação em ambientes reais ................................................................. 94

4.2.3 Radiação síncrotron - Linha de luz TGM (LNLS) ……........................................... 95

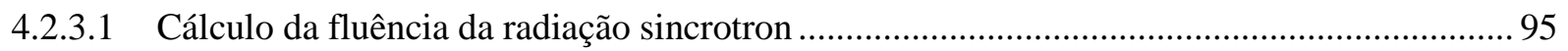

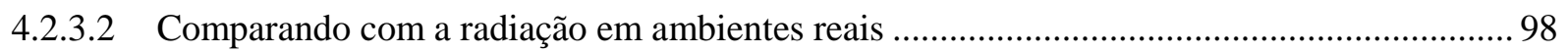

4.2.3.3 Medida dos efeitos da irradiação por reflectância no UV-Vis ...............................................99

4.2.3.4 Análise dos limites de detecção - espectros de reflectância no UV-Vis............................... 102

4.2.3.5 Medida dos efeitos da irradiação por espalhamento Raman ................................................. 108

4.2.3.6 Análise dos limites de detecção - espectros Raman .............................................................. 109

4.3 EXPERIMENTOS NA ESTRATOSFERA: balões de alta-altitude .................................... 110

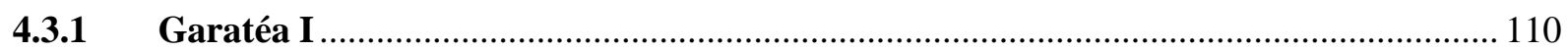

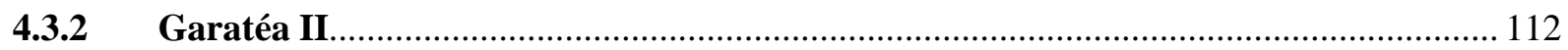

4.3.2.1 Medida dos efeitos da irradiação por espalhamento Raman ................................................ 112

4.3.2.2 Análise dos limites de detecção das amostras pelos espectros Raman ................................ 115

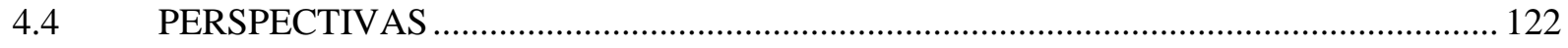

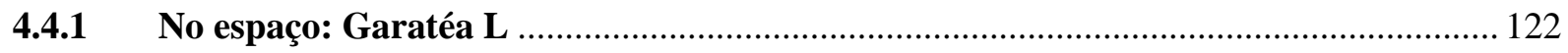

4.4.2 Experimentos na estratosfera: Garatéa III …............................................................... 124

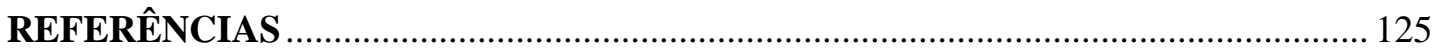

APÊNDICE A - Espectros complementares dos experimentos na AstroCam .................... 133

APÊNDICE B - Espectros complementares dos experimentos na linha TGM ................... 135

APÊNDICE C - Espectros complementares dos experimentos da Garatéa II .................... 137 


\section{INTRODUÇÃO}

\subsection{ASTROBIOLOGIA}

A astrobiologia surgiu da conexão entre diferentes áreas da ciência moderna em busca de uma melhor compreensão sobre o fenômeno da vida na Terra e, possivelmente, em outros lugares do Universo. Suas diversas subáreas estudam a origem, distribuição, evolução e futuro da vida, sempre a considerando como um fenômeno natural conectado e co-evoluindo com o planeta e o ambiente astrofísico. É um campo de pesquisa relativamente recente, de conteúdo multidisciplinar, cujo bom funcionamento se apoia em um esforço interdisciplinar com uma forte integração dos conhecimentos em astronomia, física, química, biologia, ciências planetárias, geologia, e áreas correlatas.

Esse campo de pesquisa está em grande expansão na comunidade científica internacional, como por exemplo nos Estados Unidos com o NASA Astrobiology Institute (NAI), e na Europa com a European Astrobiology Network Association (EANA). O Brasil tem dado importantes passos desde o início em 2006 das colaborações virtuais do Grupo Brasileiro de Astrobiologia (AstroBio-Brazil, registrado no CNPq). Em 2010 foi aprovada, pela Universidade de São Paulo, a criação do Núcleo de Apoio à Pesquisa em Astrobiologia (NAP/Astrobio, PRP-USP), o qual foi aceito em 2011 como parceiro internacional da NAI e da EANA. A atividade de grupos trabalhando com temas relacionados a astrobiologia no Brasil tem aumentado progressivamente nos últimos anos, impulsionada pelo interesse da comunidade no tema, pelo crescente acesso a dados astronômicos provenientes de cada vez mais potentes telescópios espaciais e terrestres e de sondas planetárias, pelo interesse das agências de fomento em financiar projetos interdisciplinares de grande escopo e pelo interesse do público. (1)

\subsection{O FENÔMENO DA VIDA}

A vida como a conhecemos na Terra - e única forma até então conhecida - é baseada em compostos orgânicos complexos interagindo em água líquida. É muito pouco provável que estruturas tão elaboradas como as de proteínas, DNA, carboidratos e lipídeos possam surgir por si próprias e ao mesmo tempo na superfície de um planeta. Elas resultam de uma evolução química complexa longe de ser totalmente compreendida, que tem seu início nos núcleos de gigantes vermelhas onde a nucleossíntese dos átomos de carbono ocorre, e passa por diferentes ambientes astrofísicos como o meio interestelar, nuvens moleculares, discos de acreção, e 
eventualmente na atmosfera ou na superfície de um planeta ou de um corpo pequeno (cometa ou asteroide).

Nesse processo, os elementos se organizam em compostos orgânicos cada vez mais complexos e, em algum estágio ainda não definido de complexidade e organização da matéria, um importante passo foi dado e a química se transformou em biologia.

Portanto, se vida já surgiu e evoluiu e ainda existe em algum outro lugar do Universo, ela é muito provavelmente constituída de uma química orgânica - macromoléculas baseadas em carbono que podem participar de reações químicas e com diferentes capacidades, como carregar informações para a propagação da vida com alto grau de especificidade, capturar e armazenar energia para transformá-la em química, oferecer compartimentalização e proteção celular, entre outras - considerando a ubiquidade desse tipo de química no universo. (2)

\subsection{BIOASSINATURAS MOLECULARES}

Encontrar vida fora da Terra traria, de imediato, a resposta para uma das mais importantes questões da humanidade - "Estamos sozinhos no Universo?" -, além de trazer pistas sobre os possíveis ambientes e processos químicos que promoveram a biogênese.

Com este objetivo, buscas têm sido realizadas fora da Terra pelas chamadas bioassinaturas, que são quaisquer objetos, substâncias ou padrões que evidenciem a presença de vida, passada ou presente, em algum ambiente. Sua origem requer um agente biológico (organismo vivo), ou seja, são sintetizadas apenas por processos biológicos, não havendo rotas abióticas para sua síntese. As bioassinaturas podem ser de diversas naturezas, como elementos químicos, isótopos, moléculas, estruturas morfológicas ou até fenômenos. O presente trabalho é focado em moléculas, as chamadas bioassinaturas moleculares.

Com base no que já é conhecido sobre a origem da vida, a busca por bioassinaturas moleculares deve ter como base as biomoléculas orgânicas da vida terrestre. Portanto, é muito importante a construção de um banco de dados de biomoléculas já conhecidas, para facilitar a detecção de bioassinaturas que podem estar preservadas em qualquer outro ambiente no Universo, e eliminar falsos-positivos (tanto de contaminação terrestre, quanto de moléculas orgânicas que não possuem origem biológica).

Porém, as biomoléculas mais comuns da vida terrestre são facilmente modificadas e degradadas, térmica ou quimicamente, sob condições ambientais severas (como no espaço ou em corpos terrestres sem atmosfera e magnetosfera). Assim, as macromoléculas da vida como a conhecemos tendem a ser pouco preservadas, se transformando em compostos derivados e, 
eventualmente, carbono. No entanto, a decomposição química de algumas biomoléculas produz compostos reconhecíveis que são preservados a longo prazo, cuja detecção indicaria inequivocamente a presença de vida extinta ou ainda existente. Esses produtos de degradação são apelidados de "fósseis moleculares", e tem sido alvos nas buscas por vida fora da Terra. (3)

Portanto, a busca por bioassinaturas tem sido um trabalho desafiador no campo da astrobiologia em termos da seleção de alvos potenciais e das técnicas a serem utilizadas na sua detecção, considerando seu nível de resiliência nas condições extremas dos ambientes extraterrestres.

\subsubsection{Potenciais bioassinaturas moleculares e sua detecção}

Edwards (4) e Fox e Strasdeit (5) citam exemplos de fósseis moleculares que são potenciais bioassinaturas: compostos derivados de carotenoides, datados de $1.64 \mathrm{Ga}$ (6), e produtos de degradação de clorofilas e grupos heme, as porfirinas, reportadas em xistos de óleo de 500 Ma. (7)

Carotenoides e clorofilas estão na classe de pigmentos biológicos, amplamente utilizados por organismos terrestres no desempenho de variadas funções. Ambos compostos podem ser considerados como bioassinaturas inequívocas por terem sido isolados de cianobactérias, as quais representam os microrganismos mais abundantes e, provavelmente, uma das primeiras formas de vida que surgiram na Terra (do período Arqueano, por volta de $3.8 \mathrm{Ga}$ ). (4)

Os carotenoides, representados pelos carotenos e as xantinas, são pigmentos acessórios utilizados na fotossíntese e também tem funções antioxidantes e de proteção contra radiação. Eles estão presentes em muitos organismos extremófilos, que são chamados assim por conseguirem sobreviver ou até necessitarem fisicamente de condições geoquímicas extremas, prejudiciais à maioria das outras formas de vida na Terra. A Deinoccocus Radiodurans, por exemplo, é uma bactéria não-fotossintética poliextremófila, resistente à exposição a grandes doses de radiação UV e ionizante, e condições de dessecação. Sua resistência a tais estresses está fortemente relacionada ao seu pigmento mais abundante, o carotenoide deinoxantina, que dá sua coloração vermelho-alaranjada. (8-10)

As clorofilas estão presentes nos cloroplastos das plantas, algas e cianobactérias, sendo responsável pela coloração verde destes organismos. São moléculas essenciais para a fotossíntese, desempenhando as funções de captação de luz, transferência de energia luminosa, e transformação dessa energia luminosa em energia química, sob a forma de ATP, NADPH e 
carboidratos. Um exemplo é a clorofila a, que é utilizada pelos organismos que fazem fotossíntese oxigenica, onde oxigênio é produzido durante as reações da fase clara.

Além disso, eles possuem uma coloração resultante da absorção seletiva de luz na região do visível, o que pode permitir sua detecção in situ em superfícies planetárias, e até remota em superfícies de exoplanetas (planetas situados fora do nosso sistema solar).

Dada a importância em astrobiologia, foi dado um maior foco à clorofila a e ao carotenoide $\beta$-caroteno para os estudos desde projeto. Suas estruturas químicas são mostradas na Figura 1.

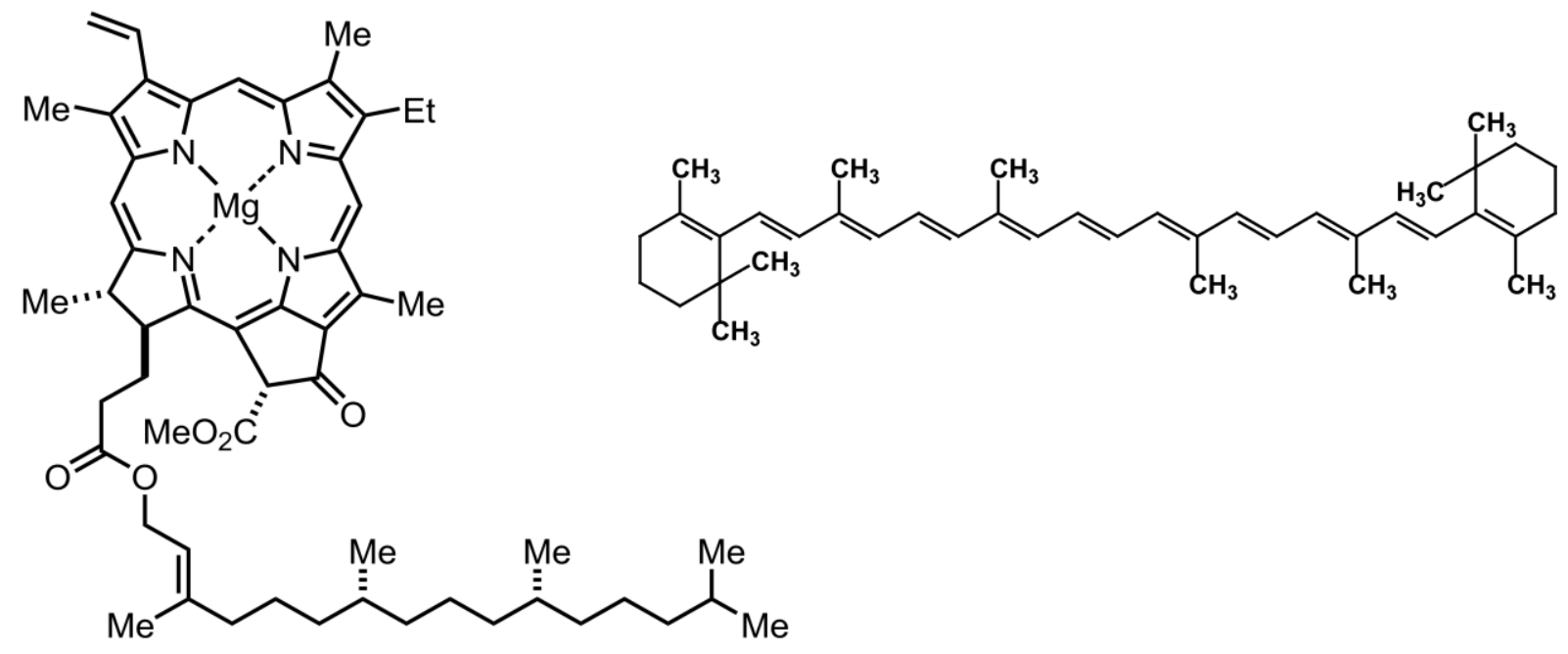

Figura 1 - Estruturas químicas dos pigmentos clorofila a (esquerda) e $\beta$-caroteno (direita). Fonte: BETA-CAROTENE (11); CHLOROPHYLL A (12)

O $\beta$-caroteno é membro dos carotenos, que são terpenoides derivados de 8 unidades de isopreno, cada um com 5 carbonos, resultando em uma longa cadeia com 40 carbonos e duplas ligações alternadas. $\mathrm{O} \beta$-caroteno $\left(\mathrm{C}_{40} \mathrm{H}_{56}\right)$ se distingue dos outros carotenos por possuir anéis $\beta$-ionona em ambas as extremidades da molécula. (13)

A clorofila a $\left(\mathrm{C}_{55} \mathrm{H}_{72} \mathrm{MgN}_{4} \mathrm{O}_{5}\right)$ possui uma estrutura derivada de um grupo porfírico, um macrociclo tetrapirrólico (formado por quatro anéis pirrólicos), ligados por ligações metínicas (-CH-), que possui no seu centro um espaço apropriado para acomodar um íon metálico, além de um quinto anel (ausente em outras porfirinas). (14) O íon metálico é o magnésio, coordenado por quatro átomos de nitrogênio presentes no centro. Além disso, há uma cadeia lateral (que difere os vários tipos de clorofilas) composta por 20 carbonos, o diterpeno fitol $\left(\mathrm{C}_{20} \mathrm{H}_{40} \mathrm{O}\right)$, ligada à uma carboxila do anel pirrólico por uma ligação éster. (15)

A detecção de bioassinaturas moleculares depende de técnicas espectroscópicas, que utiliza a interação de ondas eletromagnéticas com a matéria para obter informações sobre sua composição. Ambas as moléculas descritas acima já foram extensivamente caracterizadas por diversas técnicas espectroscópicas, como infravermelho, Raman e UV-Vis (detalhadas mais 
adiante na seção 1.7). Exemplos de tais espectros encontrados na literatura são mostrados nas Figuras 2 a 7.

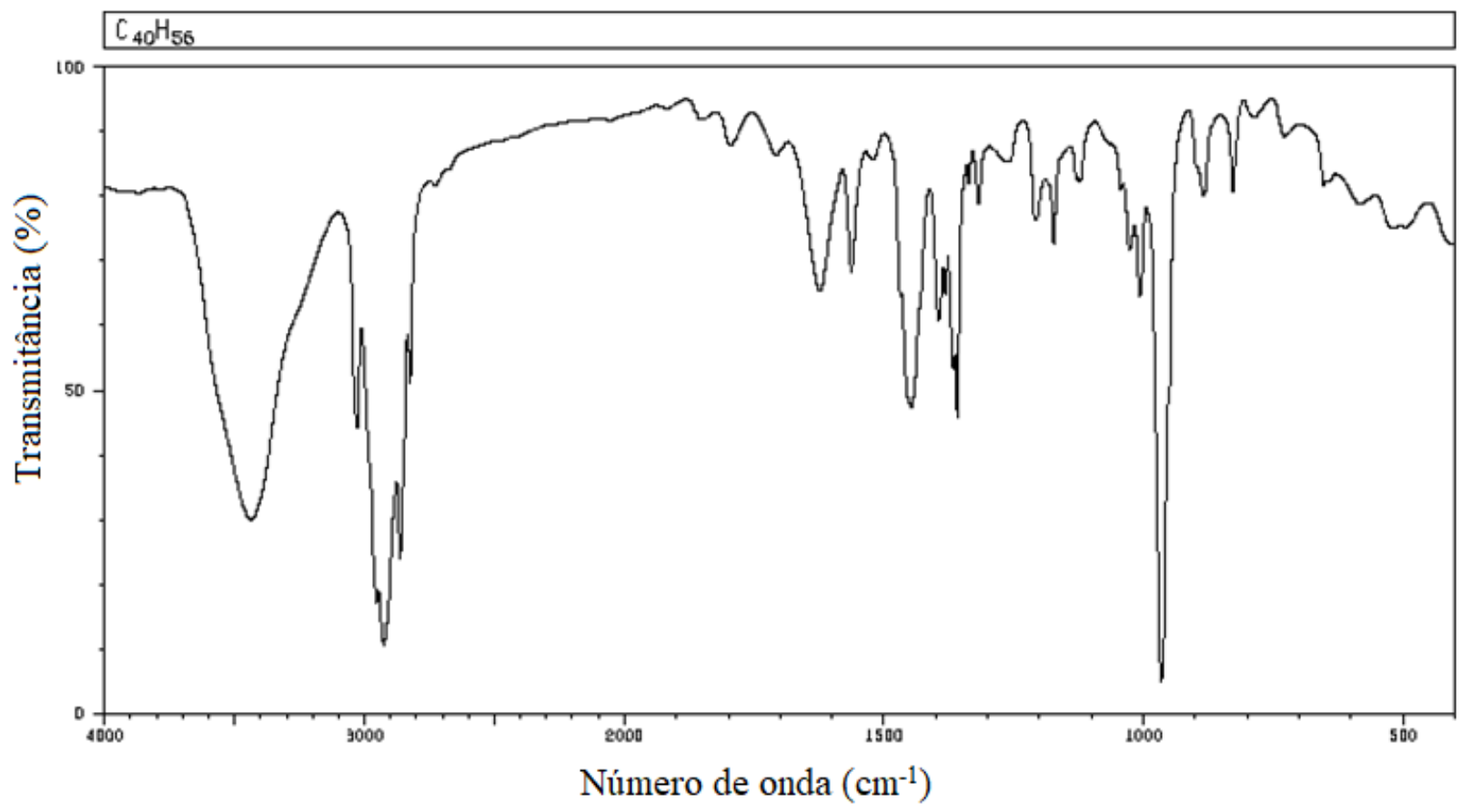

Figura 2 - Espectro no infravermelho do pigmento $\beta$-caroteno em pó, em disco de $\mathrm{KBr}$. Fonte: NATIONAL INSTITUTE OF ADVANCED INDUSTRIAL SCIENCE AND TECHNOLOGY. (16)

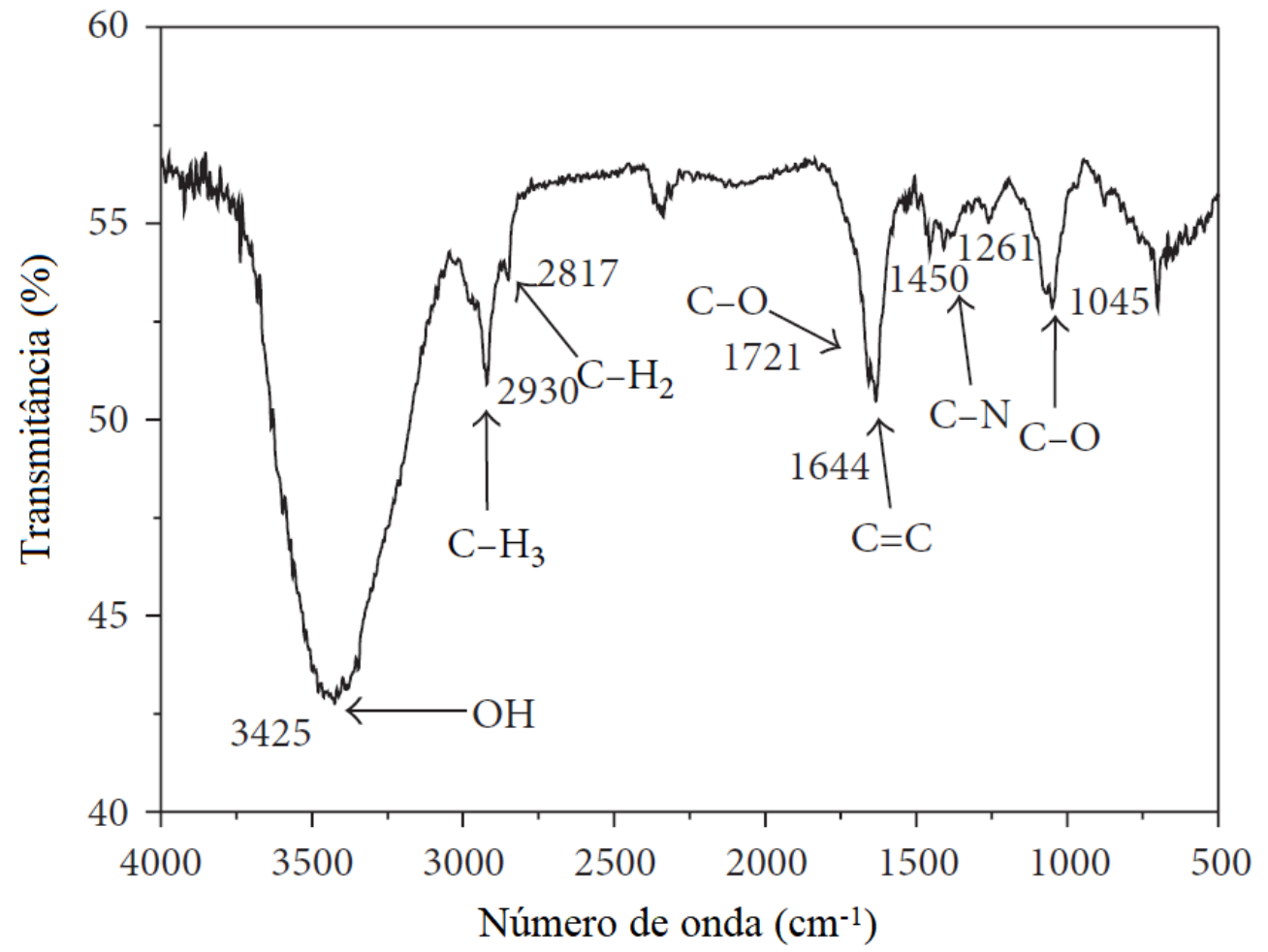

Figura 3 - Espectro no infravermelho (FTIR) do pigmento clorofila a, extraída da planta absinto (Artemisia absinthium). 


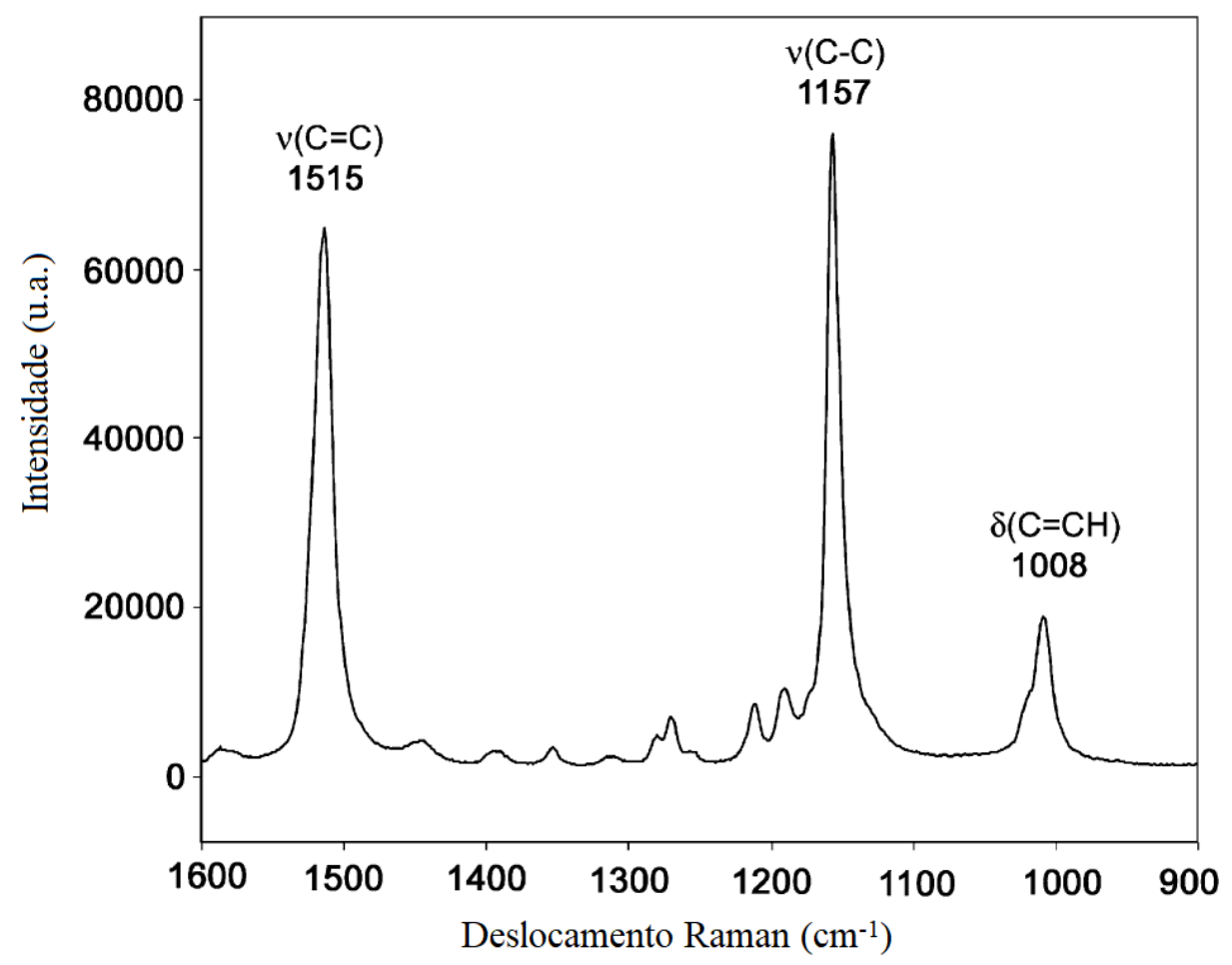

Figura 4 - Espectro Raman do pigmento $\beta$-caroteno (laser $785 \mathrm{~nm}$ ). Fonte: VÍTEK; OSTERROTHOVÁ; JEHLICKA. (18)

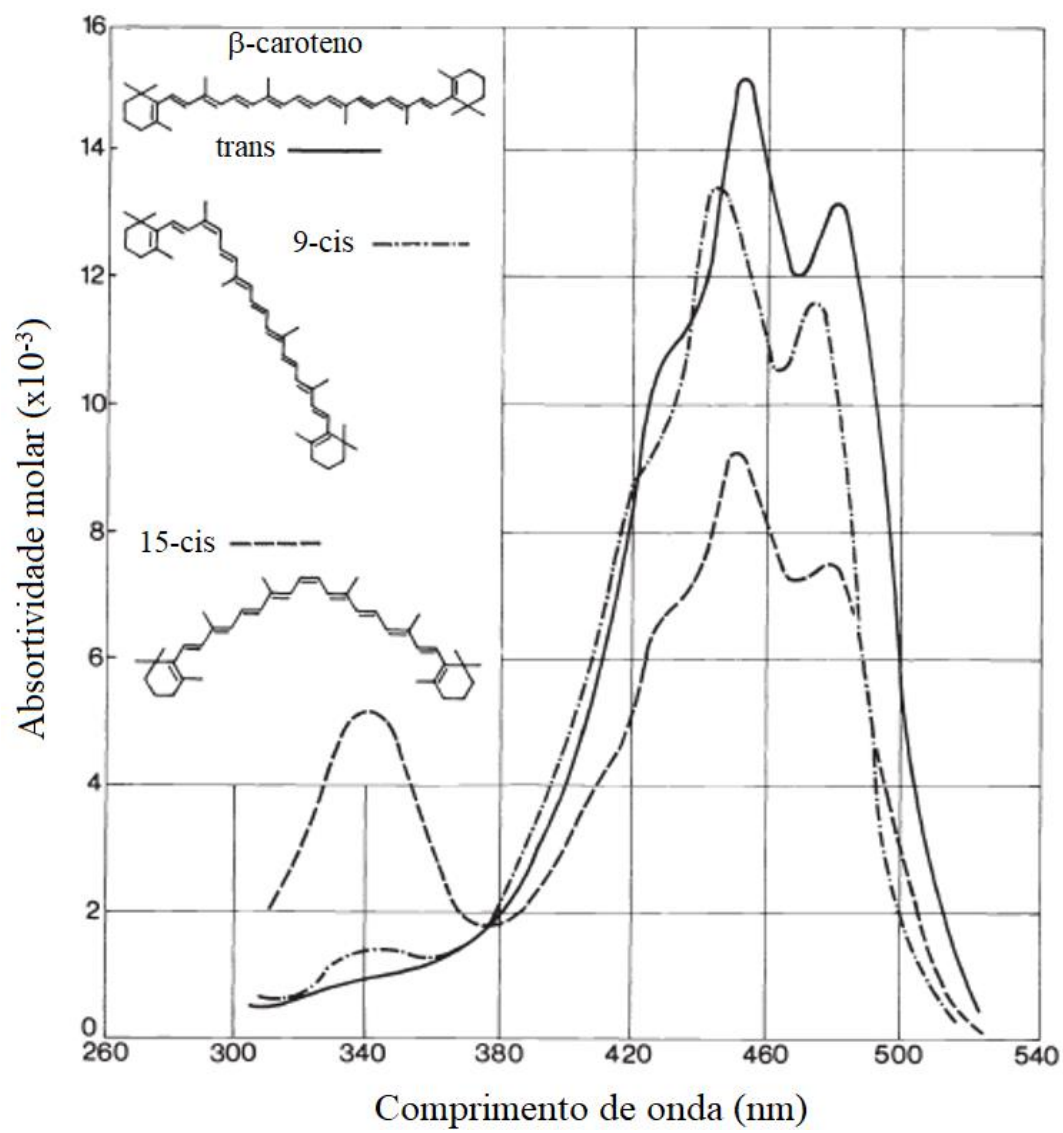

Figura 5 - Espectros de absorção no UV-Vis do pigmento $\beta$-caroteno, em três formas isoméricas diferentes (trans, 9-cis e 15-cis).

Fonte: Adaptada de ISLER; GUTMANN; SOLMS (13) 


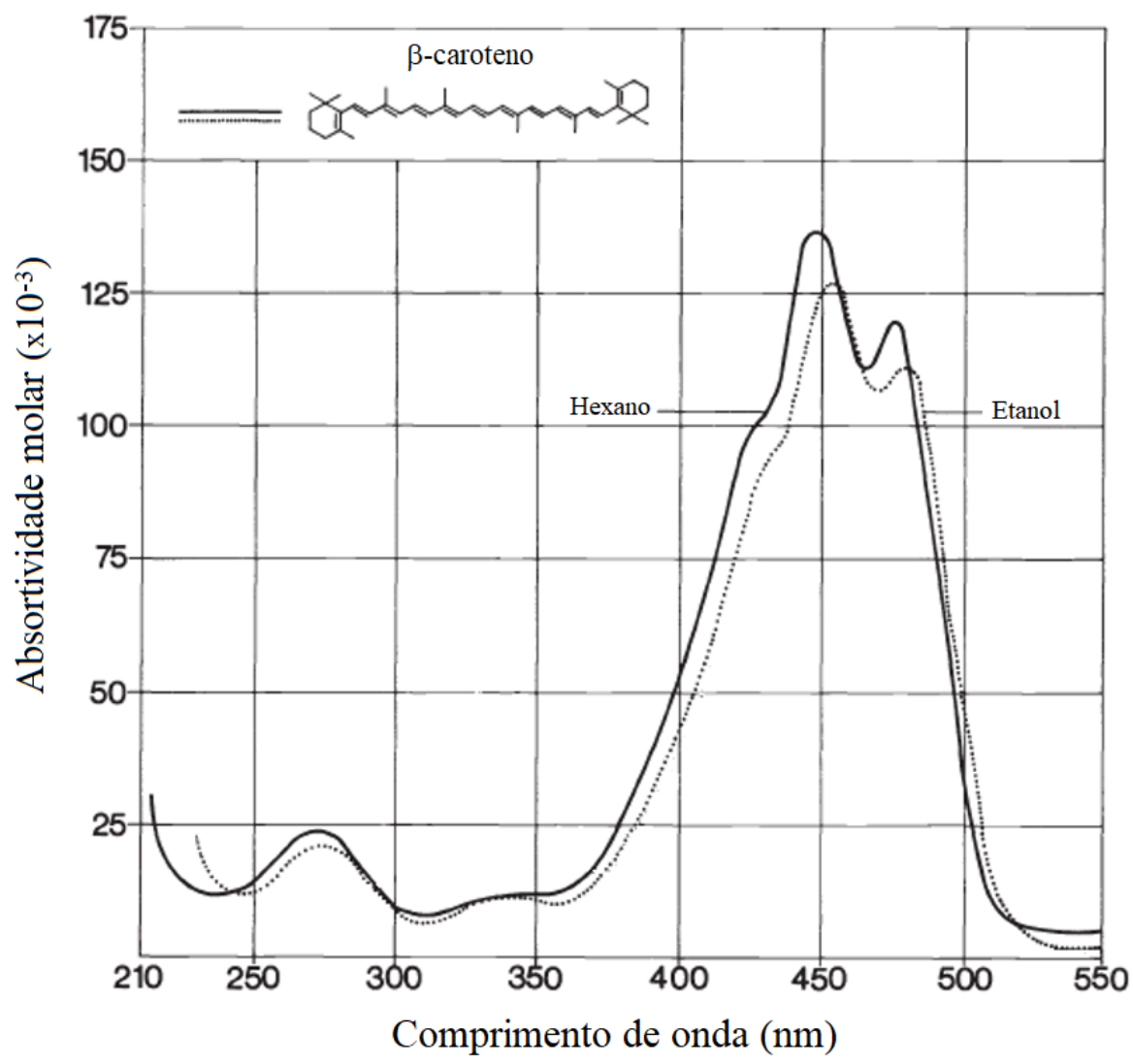

Figura 6 - Espectros de absorção no UV-Vis do pigmento $\beta$-caroteno (trans), em dois solventes diferentes (hexano e etanol).

Fonte: Adaptada de ISLER; GUTMANN; SOLMS (13)

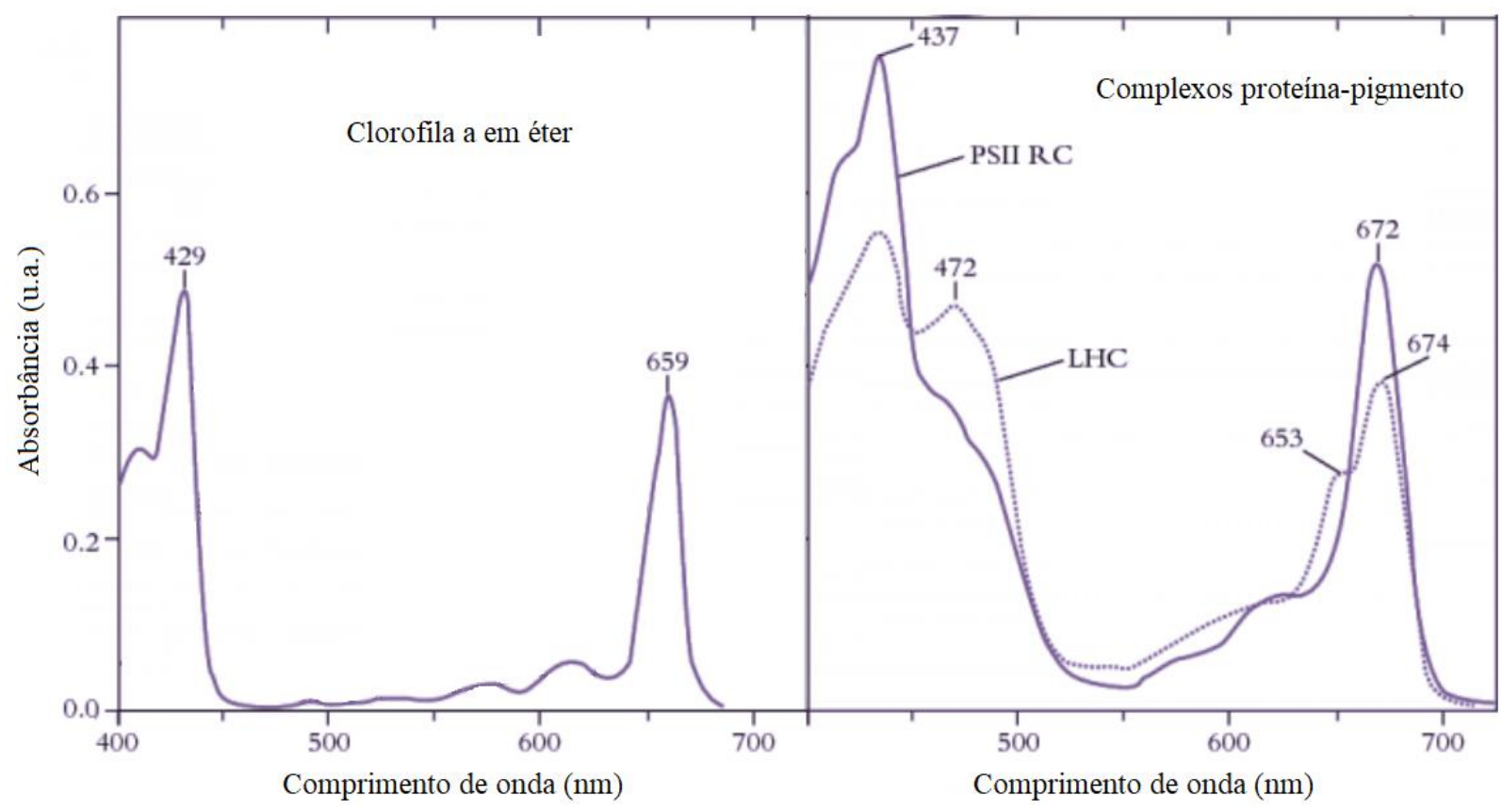

Figura 7 - Espectros de absorção no UV-Vis dos pigmentos clorofila a e b em éter (esquerda) e complexadas em proteínas do fotossistema II (PSII RC) e de captação de luz (LHC) (direita).

Fonte: Adaptada de EVANS; ANDERSON. (19) 


\subsubsection{Substratos inorgânicos}

Em ambientes reais, as bioassinaturas nunca aparecem puras ou isoladas: elas geralmente estão misturadas ou ao menos em contato com substratos inorgânicos presentes nas superfícies de planetas, cometas e asteroides. Portanto, é importante testar os efeitos dos componentes dessas superfícies, como por exemplo argilas e simulantes dos regolitos marciano e lunar (Figura 8), na evolução das potenciais bioassinaturas moleculares.

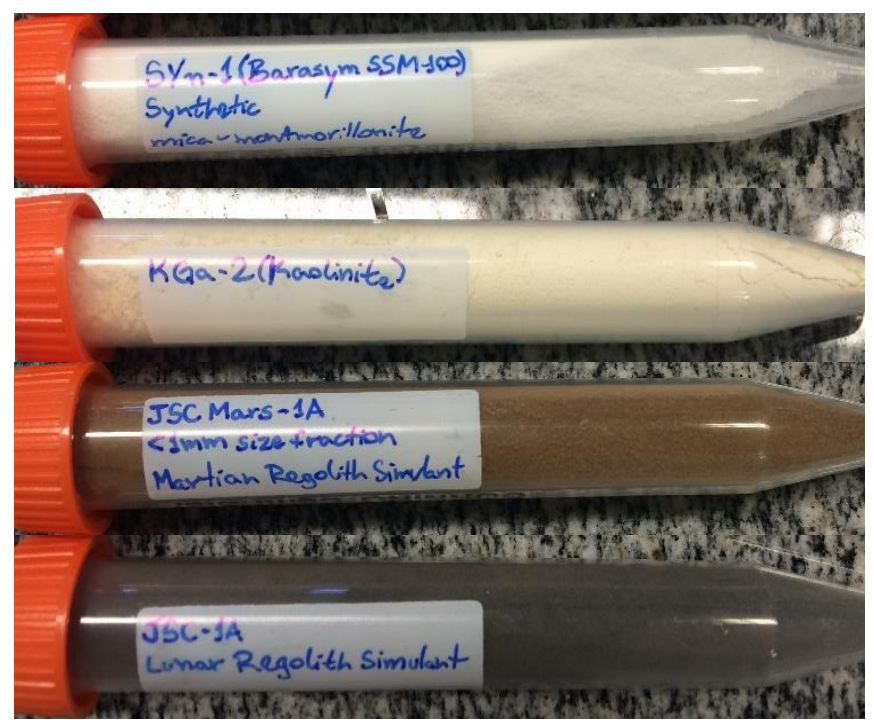

Figura 8 - Substratos inorgânicos utilizados nos experimentos. Cima para baixo: as argilas montmorilonita $\left(\mathrm{SY}_{\mathrm{n}-1}\right)$ e caulinita $\left(\mathrm{KG}_{\mathrm{a}-2}\right)$, e os simulantes dos regolitos de Marte (JSC Mars-1A) e da Lua (JSC-1A).

Fonte: Obtida pela autora.

Regolito é uma camada de material granulado solto (em sua maior parte) presente em superfícies planetárias. Essa camada também pode ter moléculas orgânicas que surgem de processos endo ou exógenos. Uma camada fina de regolito fornece proteção contra a luz solar UV, e camadas de regolito suficientemente intensas podem atenuar a radiação cósmica. Os simulantes disponíveis comercialmente do regolito Lunar (JSC-1A) e Marciano (JSC-Mars 1A) são "tefras palagoníticos", ou seja, cinzas vulcânicas alteradas a baixas temperaturas, obtidas, respectivamente, da Merriam Crater, próxima a Flagstaff, no Arizona (20), e em Pu'ú Nene, entre os vulcões Mauna Loa e Mauna Kea, no Havaí. (21) As composições de ambos os simulantes e do solo real lunar, para comparação, estão detalhados na Tabela 1. Ambos possuem composição bastante similar, com exceção da quantidade de ferro oxidado: o simulante marciano possui maior quantidade de óxido férrico $\left(\mathrm{Fe}_{2} \mathrm{O}_{3}\right)$ do que o simulante lunar. Mesmo assim, as duas misturas funcionam como bons simulantes das regiões basálticas da superfície de Marte. 
As argilas montmorilonita $\left(\mathrm{SY}_{\mathrm{n}-1}\right.$, Barasym SSM-100, tipo mica) e caulinita $\left(\mathrm{KG}_{\mathrm{a}-2}\right)$ são minerais hidratados do grupo dos filossilicatos de alumínio, com fórmulas químicas $(\mathrm{Mg}, \mathrm{Ca}) \mathrm{O} \cdot \mathrm{Al}_{2} \mathrm{O}_{3} \mathrm{Si}_{5} \mathrm{O}_{10} \cdot n \mathrm{H}_{2} \mathrm{O}$ e $\mathrm{Al}_{2} \mathrm{Si}_{2} \mathrm{O}_{5}(\mathrm{OH})_{4}$, respectivamente. Montmorilonitas são produtos de alteração de rochas ígneas efusivas, metamórficas e sedimentares em ambiente mal drenado. E caulinitas são produtos de alteração de feldspatos e outros silicatos, durante o intemperismo químico e hidrotermal. Ou seja, ambas só podem ser formadas na presença de água líquida, podendo indicar um passado quente e úmido de seu ambiente de formação. São catalisadores bem conhecidos em síntese orgânica (22), e sua relevância para a química prebiótica tem sido levantada, em hipóteses de que as reações catalisadas por minerais ajudaram na construção de materiais macromoleculares orgânicos no início do Sistema Solar. Ajudando a sustentar essa ideia, os meteoritos mais ricos em compostos orgânicos são também os mais ricos em filossilicatos. (23)

Além disso, diversos minerais hidratados já foram identificados na superfície de Marte (24). E os compostos orgânicos já identificados em Marte, em 2014 (25) e agora em 2018 (26), foram encontrados associados a lamitos, que são rochas compostas, formadas principalmente de filossilicatos. Tais descobertas confirmam o potencial de preservação de compostos orgânicos que tais substratos possuem, seja por oclusão dos compostos orgânicos em suas estruturas, ou por ligação mineral-orgânico. (23)

Tabela 1 - Composição dos regolitos lunar e marciano e de seus simulantes.

\begin{tabular}{c|c|c|c|c}
\hline Óxido & $\begin{array}{c}\text { JSC-1A } \\
\text { (\% em peso) }\end{array}$ & $\begin{array}{c}\text { Solo Lua (14163) } \\
\text { (\% em peso) }\end{array}$ & $\begin{array}{c}\text { JSC Mars-1A } \\
\text { (\% em peso) }\end{array}$ & $\begin{array}{c}\text { Solo Marte (Pathfinder) } \\
\text { (\% em peso)* }\end{array}$ \\
\hline $\mathrm{SiO}_{2}$ & 46,67 & 47,3 & $34,5-44$ & 44,0 \\
\hline $\mathrm{TiO}_{2}$ & 1,71 & 1,6 & $3,0-4,0$ & 1,1 \\
\hline $\mathrm{Al}_{2} \mathrm{O}_{3}$ & 15,79 & 17,8 & $18,5-23,5$ & 7,5 \\
\hline $\mathrm{Fe}_{2} \mathrm{O}_{3}$ & 3,41 & 0,0 & $9,0-12,0$ & 16,5 \\
\hline $\mathrm{FeO}$ & 7,57 & 10,5 & $2,5-3,5$ & $*$ \\
\hline $\mathrm{MgO}$ & 9,39 & 9,6 & $0,2-0,3$ & 5,0 \\
\hline $\mathrm{CaO}$ & 9,90 & 11,4 & $2,5-3,5$ & 2,1 \\
\hline $\mathrm{Na}_{2} \mathrm{O}$ & 2,83 & 0,7 & $5,0-6,0$ & 0,3 \\
\hline $\mathrm{K}_{2} \mathrm{O}$ & 0,78 & 0,6 & $2,0-2,5$ & n.a. \\
\hline $\mathrm{MnO}$ & 0,19 & 0,1 & $0,5-0,6$ & n.a. \\
\hline $\mathrm{P}_{2} \mathrm{O}_{5}$ & 0,71 & -- & $0,7-0,9$ &
\end{tabular}

* média de 5 solos, normalizado para $44 \%$ de $\mathrm{SiO}_{2}$

** todo ferro calculado como $\mathrm{Fe}_{2} \mathrm{O}_{3}$

n.a. = não analisado

Fonte: ALLEN. (27); RIEDER (28); GUSTAFSON. (29); JSC MARS-1A... (30) 


\subsection{INTERAÇÃO DA RADIAÇÃO COM A MATÉRIA: radiação ultravioleta}

A radiação eletromagnética das estrelas, principalmente na faixa do ultravioleta $C$, de vácuo e extremo (280 nm - $1 \mathrm{~nm}$, Figura 9), é um fator muito importante na evolução de moléculas orgânicas em ambientes espaciais: é a principal fonte de energia para a ocorrência de reações químicas e, em excesso, é um dos principais fatores responsáveis pela degradação das moléculas, e consequente destruição de bioassinaturas.

Portanto, a correta compreensão de seu papel fotoquímico nos processos de formação, transformação e destruição nos fornece importantes informações sobre a estabilidade de compostos orgânicos complexos em ambientes espaciais e/ou planetários. Levando em conta o constante intercâmbio de material orgânico entre tais meios, essas informações podem nos ajudar na compreensão da origem e evolução da vida na Terra, e possivelmente em outros lugares do Universo, facilitando a busca por bioassinaturas.

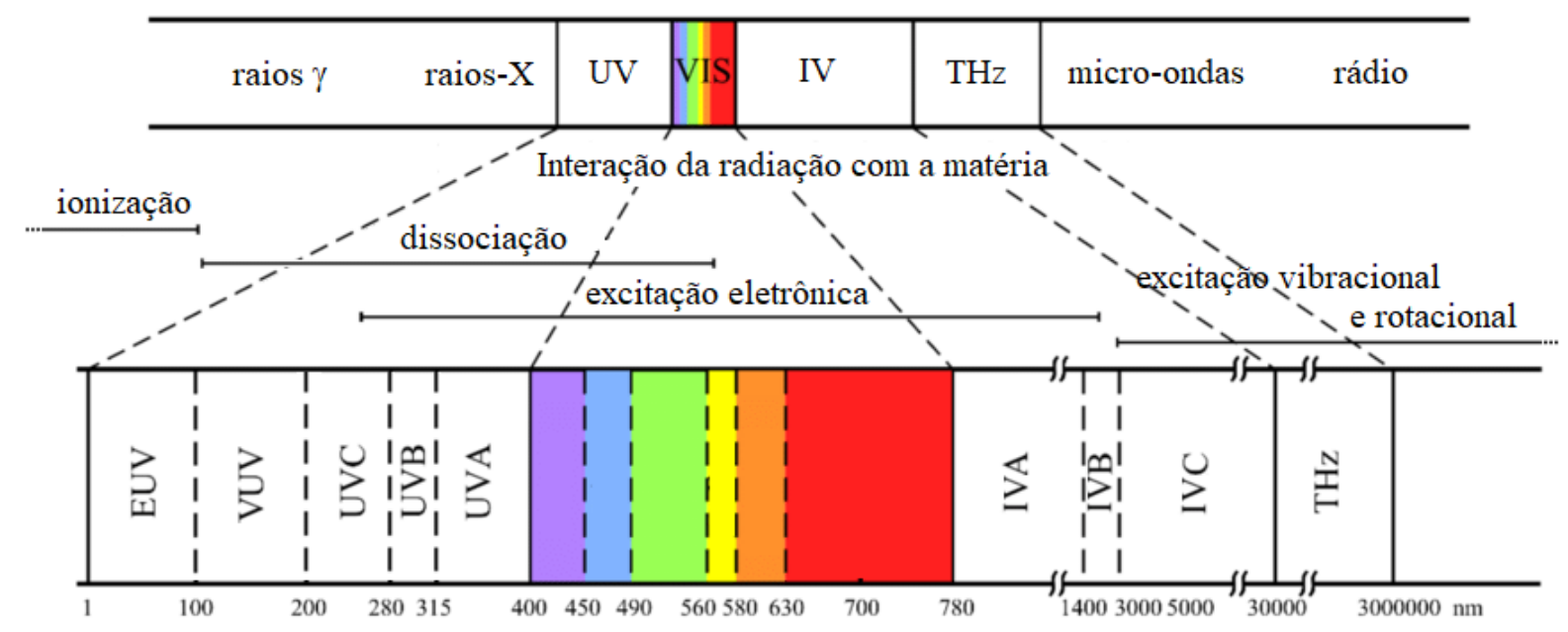

Figura 9 - Espectro eletromagnético e as principais faixas de interação da radiação com a matéria. Onde UV = ultravioleta, VIS = visível, IV = infravermelho, VUV = ultravioleta de vácuo, $\mathrm{EUV}=$ ultravioleta extremo e $\mathrm{THz}=$ terahertz.

Fonte: Adaptada de TUCHIN. (31)

O estudo das reações químicas induzidas pela radiação eletromagnética é chamado de fotoquímica. Nessas reações, a energia de ativação é fornecida pela radiação eletromagnética, dada pela energia de cada fóton:

$$
E=h v=\frac{h c}{\lambda}
$$

Onde $h$ é a constante de Planck $\left(6.625 \times 10^{-34} \mathrm{~J}^{-1}{ }^{-1}\right), v$ é a frequência da luz, $c$ é a velocidade da luz o vácuo $\left(\sim 3 \times 10^{8} \mathrm{~m} . \mathrm{s}^{-1}\right)$, e $\lambda$ é o comprimento de onda da luz. (32) 
A absorção de um fóton de luz, com energia igual à $h v$, pode conduzir uma molécula, $A B$, a um estado eletrônico excitado, $A B^{*}$, no qual ela estará mais susceptível de reagir do que no estado fundamental.

$$
A B \stackrel{h v}{\rightarrow} A B^{*}
$$

Uma vez excitada, a molécula dissipa o excesso de energia por diferentes processos físicoquímicos, entre eles:

- Luminescência: a molécula excitada emite um fóton, retornando a um estado inferior que pode ser o fundamental. $A B^{*} \rightarrow A B+h v$

- Transferência de energia intramolecular: $A B^{*} \rightarrow A B^{*}$

- Quenching: a molécula excitada perde sua energia em excesso por colisão com moléculas adjacentes de outra espécie. $A B^{*}+M \rightarrow A B+M$

- Dissociação: o excesso de energia induz a quebra de ligações, resultando em uma fotodissociação da molécula excitada. $A B^{*} \rightarrow A^{\bullet}+B^{\bullet}$

- Ionização: a molécula excitada perde um de seus elétrons. $A B^{*} \rightarrow A B^{+}+e^{-}$

Para os estudos de fotoestabilidade de bioassinaturas moleculares, um dos processos mais importantes dentre os citados é a fotodissociação das moléculas, resultando em fragmentos da mesma e/ou outros produtos decorrentes de subsequente reação.

A fotodegradação de uma molécula, $A B$, resultando nos seus fragmentos, é totalmente compreendida se a taxa de fotodegradação de $A B$ e a natureza dos fragmentos são conhecidas. Geralmente, tais estudos em laboratório se baseiam na suposição de que, se todas as moléculas da amostra são irradiadas de forma homogênea, pode-se assumir um decaimento exponencial de $1^{\mathrm{a}}$ ordem e a taxa de fotólise é descrita por:

$$
\frac{d[A]}{d t}=-J .[A] \quad \rightarrow \quad[A]=[A]_{0} e^{-J t}
$$

Onde $[A]_{0}$ e $[A]$ são, respectivamente, a densidade numérica de $A\left(\mathrm{~cm}^{-3}\right)$ no início e em certo instante $t$ da irradiação (s), e $J$ é a constante de fotólise $\left(\mathrm{s}^{-1}\right)$. Assim, encontra-se experimentalmente a constante de fotólise, $J$, da amostra, e com o valor de $J$ é possível, então, calcular a meia-vida das moléculas (o tempo em que metade da abundância inicial é destruída pela fotólise):

$$
t_{1 / 2}=\frac{\ln 2}{J}
$$

Entretanto, para que esses cálculos sejam corretos, com resultados confiáveis, as amostras irradiadas devem ser puras e opticamente finas, ou seja, 90\% dos fótons UV são transmitidos através da amostra. 
Pensando nas bioassinaturas moleculares, o interesse está nos estudos da detectabilidade espectroscópica das biomoléculas de interesse em superfícies de ambientes astrofísicos reais. Nestes ambientes, as biomoléculas nunca estarão em sua forma pura - como discutido na seção anterior - e muito menos estarão agrupadas em forma de filmes opticamente finos. Ou seja, sua detectabilidade real depende do ambiente no qual ela se encontra e, apesar de não ser possível de ser estudada por um simples decaimento de primeira ordem, é possível fazê-lo por outras formas de decaimento. Portanto, a fotoestabilidade das amostras aqui estudadas refere-se à fotoestabilidade de suas respostas espectroscópicas para cada técnica, e não das amostras em si, representando potenciais bioassinaturas nas condições mais próximas das condições reais nas quais elas podem ser um dia detectadas.

\subsection{RADIAÇÃO SÍNCROTRON}

A radiação síncrotron é a radiação eletromagnética emitida quando partículas carregadas se movendo com velocidades relativísticas são submetidas a uma aceleração radial. Tem ampla utilidade por parte da comunidade científica para estudos espectroscópicos, isto é, na finalidade de pesquisar e investigar propriedades estruturais e químicas em nível molecular a partir da interação entre a luz e a matéria. (33)

Quando uma partícula carregada é acelerada, ela irradia energia na forma de ondas eletromagnéticas. Para velocidades bem menores que a velocidade da luz, a potência total irradiada é dada pela equação de Larmor, em unidades cgs:

$$
P=\frac{2}{3} \frac{q^{2} a^{2}}{c^{3}} \quad \leftrightarrow \quad P=\frac{2}{3} \frac{q^{2}}{m^{2} c^{3}}|\dot{p}|^{2}
$$

Onde a é a aceleração $\left(\mathrm{cm} / \mathrm{s}^{2}\right)$, q é a carga (esu), p é o momento $(\mathrm{g} \mathrm{cm} / \mathrm{s})$ e $\mathrm{m}$ é a massa da partícula $(\mathrm{g})$, e c é a velocidade luz $(\mathrm{cm} / \mathrm{s})$. O que mostra que qualquer partícula carregada, quando acelerada, irradia com uma potência proporcional ao quadrado de sua aceleração. (34)

Liénard estende o resultado de Larmor para partículas relativísticas, ou seja, se movendo a velocidades próximas à da luz. Como a potência é invariante sob as transformações de Lorentz, a generalização relativística deve relacionar a potência com alguma outra quantidade também invariante. A quantidade $|\dot{p}|^{2}$ que aparece na fórmula do caso não-relativístico sugere que a fórmula do caso relativístico deve conter o escalar de Lorentz dado pelo produto interno do quadri-vetor aceleração $\left(a^{\mu}=d p^{\mu} / d \tau\right)$ por ele mesmo, onde $p^{\mu}$ é o quadri-vetor momento. Lembrando que $\tau$ é o tempo próprio da partícula, dado por $\tau=t / \gamma$, onde $\gamma=1 / \sqrt{1-\beta^{2}}$, e $\beta=v / c$. A generalização relativística correta é dada por: 


$$
P=-\frac{2}{3} \frac{q^{2}}{m^{2} c^{3}} \frac{d p_{\mu}}{d \tau} \frac{d p^{\mu}}{d \tau}
$$

O produto interno do quadri-vetor aceleração é dado pela equação 7, que se reduz a $-|\dot{p}|^{2}$ no limite $\beta \ll 1$, reproduzindo o caso não-relativístico:

$$
\frac{d p_{\mu}}{d \tau} \frac{d p^{\mu}}{d \tau}=\beta^{2}\left(\frac{d p}{d \tau}\right)^{2}-\left(\frac{d p}{d \tau}\right)^{2}
$$

Assim, a generalização relativística (equação 6) também pode ser escrita em termos de $\beta$ e sua derivada:

$$
P=\frac{2 q^{2} \gamma^{6}}{3 c}\left[(\dot{\beta})^{2}-(\beta \times \dot{\beta})^{2}\right]
$$

A dependência da potência com $\gamma^{6}$ significa que quando o fator de Lorentz é muito próximo de 1, a radiação emitida pela partícula é desprezível. Mas conforme $\beta \rightarrow 1$, ou seja, a velocidade da partícula se aproxima da velocidade da luz, a radiação cresce com $\gamma^{6}$ enquanto a partícula perde energia na forma de ondas eletromagnéticas. (35)

As vantagens de se utilizar a radiação síncrotron são:

-Ampla faixa espectral: é possível selecionar a faixa de comprimentos de onda de interesse para seu experimento, desde infravermelho até raios x duros (no LNLS, por exemplo, a faixa espectral é de $90 \mathrm{meV}$ a $30 \mathrm{keV}$ );

-Alta estabilidade: fonte com estabilidade sub-micrométrica;

-Polarização: linear e circular;

- Estrutura de tempo pulsado: comprimento do pulso de apenas dezenas de picossegundos, permitindo a resolução do processo na mesma escala de tempo;

-Alto fluxo: feixe de fótons de alta intensidade permite experimentos rápidos ou medidas de amostras com baixa interação com a radiação ou muito diluídas. O fluxo é dado pela equação 9, onde o intervalo de tempo é dado em segundos;

$$
\text { Fluxo }=\frac{n^{o} \text { de fótons }}{\text { intervalo de tempo }}
$$

- Alto brilho: feixe de fótons altamente colimado gerado por uma fonte com pequena divergência e tamanho (coerência espacial). O brilho é dado pela equação 10, onde $\mathrm{S}$ é a área da fonte e $\Omega$ é a divergência angular da fonte, e o produto entre os dois fornece a emitância da fonte.

$$
\text { Brilho }=\frac{\text { Fluxo }}{\text { S. } \Omega}
$$

O Laboratório Nacional de Luz Síncrotron (LNLS), localizado em Campinas/SP - Brasil, tem operado a única fonte de luz síncrotron da América Latina desde julho de 1997. É um dos 
laboratórios que integram o Centro Nacional de Pesquisa em Energia e Materiais (CNPEM), diretamente ligado ao Ministério da Ciência, Tecnologia, Inovações e Comunicação (MCTIC). O esquema geral de um acelerador fonte de luz síncrotron está mostrado na Figura 10.

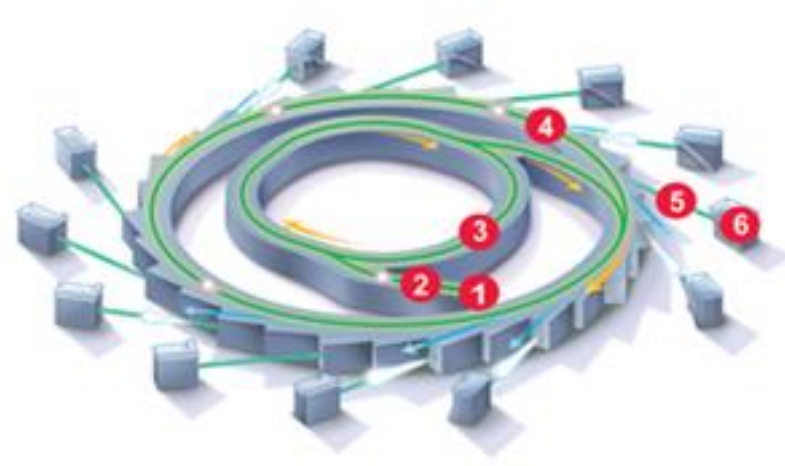

(1) Canhão de elétrons

(2) LINAC

(3) Anel booster

(4) Anel de armazenamento

(5) Linha de luz

(6) Estação experimental

Figura 10 - Esquema geral de um acelerador fonte de luz síncrotron.

Fonte: HOW... (36)

No LNLS, a produção de luz síncrotron acontece em um anel de armazenamento de 27 metros de diâmetro (Figura 11), chamado de UVX, que usa campos magnéticos e campos elétricos oscilantes de radiofrequência para acelerar elétrons a velocidades próximas à da luz.

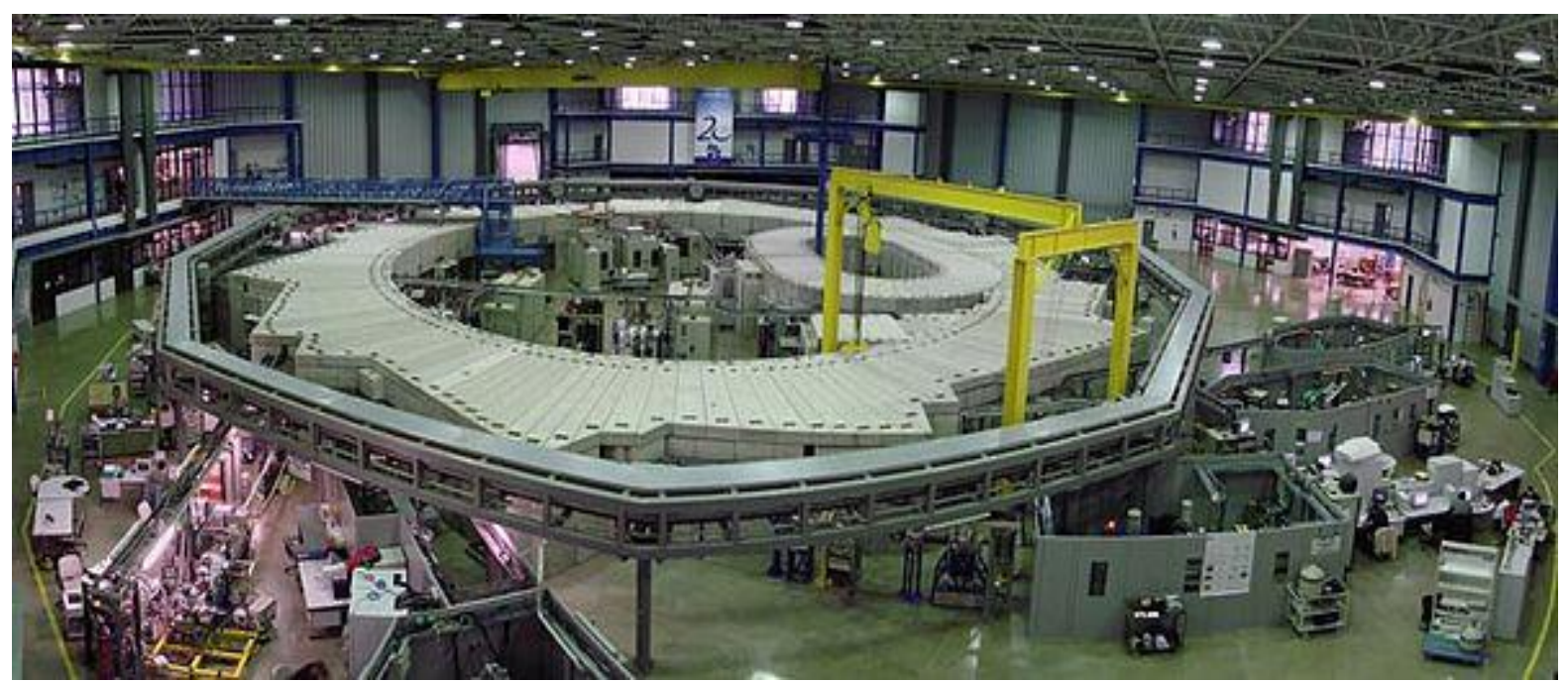

Figura 11 - Vista superior do anel de armazenamento de elétrons, fonte de luz síncrotron, do LNLS (UVX) e de suas estações experimentais.

Fonte: Obtida pela autora.

A produção dos elétrons começa num canhão de elétrons do tipo triodo (cátodo, cilindro de Wehnelt e anodo), onde cerca de 200 mil Volts são aplicados em um filamento de tungstênio (cátodo) aquecendo-o até cerca de $1000{ }^{\circ} \mathrm{C}$, quando ocorre a ejeção de elétrons em pulsos que 
são direcionados até o anodo, acelerando-os a $80 \mathrm{keV}$. Esses elétrons vão para o primeiro elemento do sistema de injeção, o LINAC (acelerador linear), que utiliza um sistema de RádioFrequência (Sistema RF) a $2.856 \mathrm{GHz}$ para acelerá-los de $80 \mathrm{keV}$ a $120 \mathrm{MeV}$. O segundo elemento do sistema de injeção é o anel booster (ou intensificador) que também utiliza um sistema RF a $476 \mathrm{MHz}$ para acelerar os elétrons de $120 \mathrm{MeV}$ a $500 \mathrm{MeV}$. São utilizados imãs dipolares com 1,63 T para manter a trajetória dos elétrons no anel, e imãs quadrupolares para manter o feixe colimado.

Os elétrons são, então, injetados no anel de armazenamento, uma vez por segundo durante cerca de 10 minutos, para alcançar uma corrente de $250 \mathrm{~mA}$. Um sistema RF a $476 \mathrm{MHz}$ acelera os elétrons de $500 \mathrm{MeV}$ a $1,37 \mathrm{GeV}$, mas eles perdem cerca de $114 \mathrm{keV}$ por volta no anel, o que resulta em um tempo de vida de cerca de 17 horas. Há seções retas no anel com eletroímãs defletores $(1,67 \mathrm{~T})$ que aceleram os elétrons e provocam uma curvatura em sua trajetória, durante a qual perdem energia em forma de luz síncrotron - altamente brilhante e focalizada -, que é depois reposta por uma cavidade de ressonância. Essa luz é então canalizada por prolongamentos do anel para linhas de luz que selecionam diferentes faixas espectrais para serem utilizadas em experimentos de variados tipos nas estações experimentais. Atualmente há 20 linhas de luz em operação no LNLS (17 delas abertas para a comunidade de usuários), cobrindo energias de poucos eV (elétron-Volts) até keV.

A Figura 12 mostra o fluxo da radiação síncrotron no LNLS em função da energia dos fótons, obtido com o dipolo de 1,67 Tesla. A emitância (S. $\Omega$ ) chega ao valor de 100 nm.rad (no ponto de máxima energia). $(33,37)$

Operando desde 1997, a linha TGM, do inglês Toroidal Grating Monochromator (Monocromador de Grade Toroidal), trabalha na faixa de energia do ultravioleta (UV), ultravioleta de vácuo (VUV) e ultravioleta extremo (EUV), de 3 a $330 \mathrm{eV}$, o que equivale a aproximadamente 400 a $4 \mathrm{~nm}$. Essa faixa de energia é capaz de promover ionização de moléculas e quebra de ligações químicas, sendo importante para estudos de compostos relacionados a ambientes astrofísicos. Essa linha pode ser utilizada, portanto, para simular as condições extremas de ambientes espaciais, com alta taxa de radiação UV e em ultra alto vácuo.

Recentemente, foi instalado um sistema para medidas óticas na estação experimental. Assim, é possível realizar medida de luminescência e reflectância difusa, in situ e em tempo real, das amostras sendo irradiadas. (38-39) 


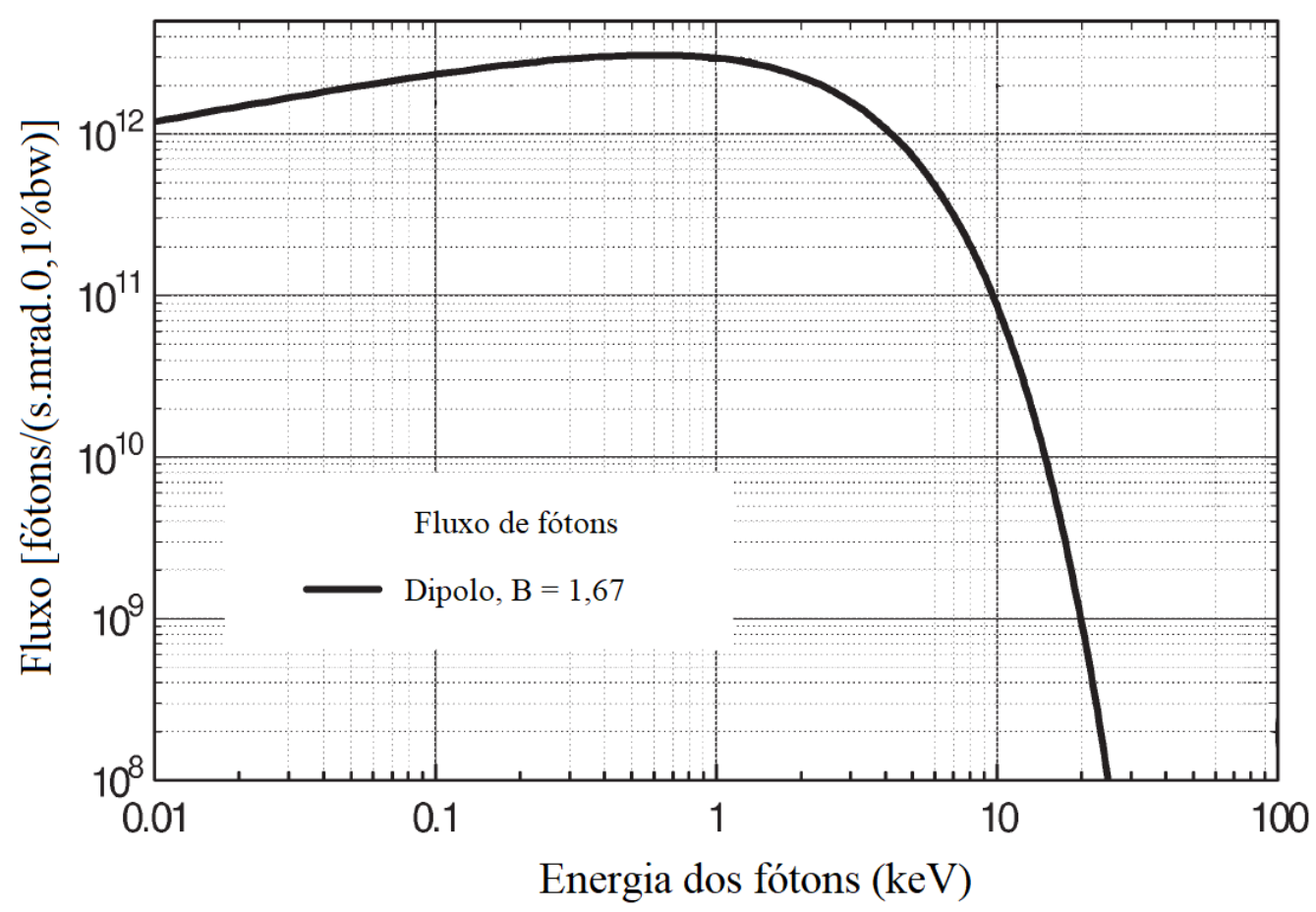

Figura 12 - Fluxo da radiação síncrotron no LNLS em função da energia dos fótons. Fonte: CRAIEVICH; RODRIGUES. (33)

\subsection{MISSÕES ESPACIAIS}

\subsubsection{Balões de alta-altitude}

Balões de alta-altitude (ou balões estratosféricos) são veículos espaciais sub-orbitais muito utilizados como ferramentas em pesquisas científicas astronômicas e da atmosfera. Atualmente também são utilizados para testes de novas tecnologias antes de serem enviadas em satélites para missões espaciais de longa duração.

São geralmente feitos de um filme plástico fino, inflado com gás hidrogênio ou hélio, capaz de levar cargas de até 3 toneladas a altitudes de até $45 \mathrm{~km}$. Simples e de baixo custo, não necessitam de motor e combustível, voam a favor dos ventos e as cargas úteis podem ser recuperadas após voos de até dezenas de horas, o que faz dos balões estratosféricos ferramentas ambientalmente responsáveis para pesquisas científicas e desenvolvimento tecnológico. (40)

Esses veículos representam uma alternativa para a condução de experimentos relevantes a astrobiologia, já que as condições na estratosfera da Terra (12 a 50 km acima do nível do mar) podem mimetizar ambientes extremos - com alta taxa de radiação e baixas pressões, temperaturas e umidades - como a superfície de Marte, um local ainda não facilmente acessível. 
Além disso, os balões têm sido utilizados para a validação de instrumentação e metodologia para missões espaciais. (41-42)

O grupo colaborador do presente projeto responsável pelo desenvolvimento de balões estratosféricos é o "Zenith-USP”, baseado na Escola de Engenharia de São Carlos (EESC) da Universidade de São Paulo (USP). É formado por estudantes de graduação e pós-graduação que realizam trabalhos extracurriculares voltados para o estudo e desenvolvimento de sistemas com aplicação na indústria aeroespacial. (43)

\subsubsection{Baixa órbita terrestre e CubeSats}

Diversos experimentos em laboratório são dedicados ao estudo de fotoquímica de moléculas em fases sólida e gasosa ou moléculas voláteis condensadas a temperaturas muito baixas. No entanto, há discrepâncias consideráveis entre os ambientes simulados em laboratório e os ambientes espaciais reais. A validação e extrapolação dos dados de laboratório para ambientes reais podem ser facilitadas se comparadas a experimentos similares realizados no espaço, com exposição ao espectro solar completo, vácuo, radiação ionizante, flutuações de temperatura e micro-gravidade, as quais são difíceis ou impossíveis de se reproduzir em laboratório (44-45)

Estudos sobre a evolução da matéria orgânica submetidas às condições espaciais têm sido realizados na Baixa Órbita Terrestre (LEO, em inglês, 400-500 km de altitude) desde a década de 1990, a bordo de várias plataformas espaciais, resumidos na Tabela 2.

Embora essas plataformas tenham fornecido resultados importantes, há limitações significativas que restringem suas capacidades e retorno científico:

i) Estudos críticos de cinética e dinâmica de reação não podem ser realizados devido à falta de análise in situ em função do tempo. Apenas duas medidas são disponíveis (uma antes da exposição e uma após o retorno da amostra), de modo que o comportamento das amostras entre os dois pontos é baseado em suposições;

ii) Os dispositivos atuais são colocados em instalações em uma órbita baixa (<500 km) em um nível onde a maioria das partículas solares e cósmicas já foram filtradas pelo campo magnético da Terra, diferente do espaço profundo;

iii) Atualmente, não é possível realizar experimentos de exposição em amostras mantidas a baixa temperatura (gelo puro ou misturas a $\sim 10-77 \mathrm{~K}$ ), enquanto esse tipo de experiência é comum no laboratório para entender melhor a química do gelo interestelar, cometário, e de luas geladas. 
Com o uso de CubeSats, foi alcançado um avanço significativo para as limitações citadas acima. São pequenos satélites cúbicos, geralmente com $10 \mathrm{~cm}$ de aresta por unidade (U), que oferecem a capacidade de medidas analíticas cada vez mais sofisticadas em "pacotes" pequenos, leves, baratos e que necessitam de pouca energia, adaptáveis a muitas missões espaciais e planetárias.

O nanosatélite da NASA O/OREOS (Organism/Organic Exposure to Orbital Stresses) foi operado na LEO $(<600 \mathrm{~km})$ de novembro de 2010 a maio de 2011, e o OREOcube da ESA deve ser instalado na ISS em 2020, ambos com medidas in situ na região do ultravioleta ao IR próximo (UV-Vis-NIR). Ambas missões também são resumidas na Tabela 2.

O experimento SEVO (Space Environment Viability of Organics) expôs 4 classes de biomoléculas em 4 microambientes simulando as condições do espaço interplanetário, corpos sem atmosfera, Marte "seco" e Marte "úmido" (primitivo). Os espectros obtidos, de qualidade comparável aos obtidos em laboratório, provaram a funcionalidade de um sistema espectroscópico a bordo de uma unidade CubeSat e o sucesso das primeiras medidas de fotoquímica in situ e em tempo real. E o experimento OREOcube (ORganics Exposure in Orbit) é uma adaptação da instrumentação do O/OREOS para a ISS. A instalação irá expor filmes finos de compostos orgânicos e minerais para acompanhar sua degradação in situ e em tempo real, com a vantagem de recuperar as amostras após 12 meses para análise posterior. O objetivo é estudar o papel das superfícies minerais na evolução fotoquímica, transporte e distribuição de moléculas orgânicas para o meio interestelar, cometas, meteoritos e outros corpos, também simulando diferentes microambientes.

Tabela 2 - Missões espaciais sobre a evolução da matéria orgânica e resumo dos resultados.

\begin{tabular}{c|c|c|l}
\hline Ano & Plataforma & Experimento & \multicolumn{1}{c}{ Interesse/Conclusão } \\
\hline 1994 & $\begin{array}{c}\text { Biopan I } \\
\text { Biopan II }\end{array}$ & $\begin{array}{c}\text { DUST } \\
(46-47)\end{array}$ & $\begin{array}{l}\text { Aminoácidos são facilmente degradados no espaço exceto } \\
\text { quando são protegidos por uma matriz mineral. }\end{array}$ \\
\hline 1999 & MIR & $\begin{array}{c}\text { Perseus- } \\
\text { Exobiologie } \\
(48)\end{array}$ & $\begin{array}{l}\text { Aminoácidos são facilmente degradados no espaço exceto } \\
\text { quando são protegidos por uma matriz mineral. }\end{array}$ \\
\hline 2005 & Biopan V & $\begin{array}{c}\text { ORGANICS } \\
(49)\end{array}$ & $\begin{array}{l}\text { Hidrocarbonetos Policíclicos Aromáticos (PAHs) são } \\
\text { moléculas muito estáveis no espaço. }\end{array}$ \\
\hline 2007 & Biopan VI & $\begin{array}{c}\text { UVolution } \\
(45),(50-51)\end{array}$ & $\begin{array}{l}\text { Misturas gasosas em celas fechadas permitiram a comparação } \\
\text { da cinética da fotólise no espaço e no laboratório para } \\
\text { amostras sólidas relacionadas a cometas e a Marte. }\end{array}$ \\
\hline 2008 & $\begin{array}{c}\text { EXPOSE-E } \\
\text { (ISS) }\end{array}$ & $\begin{array}{c}\text { PROCESS } \\
(52-54)\end{array}$ & $\begin{array}{l}\text { 40 amostras sólidas e gasosas expostas em celas abertas e } \\
\text { fechadas. Foram medidas a fotoestabilidade de aminoácidos } \\
\text { e ácidos carboxílicos, e calculados tempos de vida. }\end{array}$ \\
\hline
\end{tabular}


Tabela 2 - Missões espaciais sobre a evolução da matéria orgânica e resumo dos resultados (continuação)

\begin{tabular}{|c|c|c|c|}
\hline Ano & Plataforma & Experimento & Interesse/Conclusão \\
\hline $\begin{array}{c}2009 \\
- \\
2011\end{array}$ & $\begin{array}{l}\text { EXPOSE-R } \\
\quad \text { (ISS) }\end{array}$ & $\begin{array}{c}\text { AMINO } \\
59)\end{array}$ & $\begin{array}{l}\text { - Exposição de } \mathrm{CH}_{4} \text { mostrou que seu consumo leva à } \\
\text { formação de hidrocarbonetos saturados, sem influência } \\
\text { aparente do } \mathrm{CO}_{2} \text {. } \\
\text { - Exposição de pequenos RNAs funcionais teve um efeito } \\
\text { degradante intenso na distribuição de tamanhos de RNA, e } \\
\text { radiação solar degradou as bases nucleotídicas. } \\
\text { - Exposição de aminoácidos e dipeptídeo confirmaram que a } \\
\text { resistência à radiação UV depende da natureza química da } \\
\text { molécula e dos comprimentos de onda da fonte de UV, e que } \\
\text { revestimento com pó de meteorito tem efeito de proteção. } \\
\text { Algumas moléculas provaram ser estáveis o suficiente para } \\
\text { sobreviver a um transporte no meio interestelar, } \\
\text { principalmente se estiverem incorporadas no mineral } \\
\text { apropriado. }\end{array}$ \\
\hline $\begin{array}{l}2010 \\
2011\end{array}$ & O/OREOS & $\begin{array}{c}\text { SEVO }(60- \\
64)\end{array}$ & $\begin{array}{l}\text { - Exposição de uma porfirina, um PAH, um aminoácido e } \\
\text { uma quinona em } 4 \text { diferentes microambientes que imitavam } \\
\text { as condições do espaço interplanetário. } \\
\text { - Espectros provaram funcionalidade de espectroscopia a } \\
\text { bordo de uma unidade de CubeSat e o sucesso das primeiras } \\
\text { medidas de fotoestabilidade de moléculas in situ e em tempo } \\
\text { real. }\end{array}$ \\
\hline $\begin{array}{c}2009 \\
- \\
2011\end{array}$ & $\begin{array}{l}\text { EXPOSE-R } \\
\quad \text { (ISS) }\end{array}$ & $\begin{array}{c}\text { ORGANIC } \\
(65,66)\end{array}$ & $\begin{array}{l}\text { A alta estabilidade dos PAHs (pequenas mudanças } \\
\text { espectrais) expostos à radiação espacial depende da estrutura } \\
\text { molecular: os mais compactos são mais estáveis do que os } \\
\text { não-compactos, que por sua vez são mais estáveis que PAHs } \\
\text { contendo heteroátomos. }\end{array}$ \\
\hline $\begin{array}{l}2015 \\
2016\end{array}$ & $\begin{array}{l}\text { EXPOSE- } \\
\text { R2 (ISS) }\end{array}$ & PSS (67) & $\begin{array}{l}\text { Exposição de } 75 \text { amostras de compostos orgânicos } \\
\text { relacionados ao meio interestelar, meteoritos, cometas, } \\
\text { planetas e luas. }\end{array}$ \\
\hline $\begin{array}{l}2015 \\
2016\end{array}$ & $\begin{array}{l}\text { EXPOSE- } \\
\text { R2 (ISS) }\end{array}$ & $\begin{array}{c}\text { BIOMEX } \\
(67,68)\end{array}$ & $\begin{array}{l}\text { - Medidas da resistência e estabilidade de biomoléculas, } \\
\text { como pigmentos biológicos e componentes celulares, em } \\
\text { ambientes espaciais e sob condições marcianas. } \\
\text { - Análise da sobrevivência de extremófilos terrestres no } \\
\text { espaço e determinação de quais interações entre amostras } \\
\text { biológicas e minerais (terrestre, e análogos do solo da Lua e } \\
\text { de Marte) podem ser observadas sob condições espaciais e } \\
\text { marcianas. }\end{array}$ \\
\hline 2020 & ISS & $\begin{array}{c}\text { OREOcube } \\
\text { (69) }\end{array}$ & $\begin{array}{l}\text { - Combinará medidas in situ com medidas em laboratório } \\
\text { após retorno (12 meses), para caracterizar orgânicos e } \\
\text { minerais. } \\
\text { - Amostras escolhidas com o objetivo de estudar o papel que } \\
\text { superfícies minerais desempenham na evolução fotoquímica, } \\
\text { transporte e distribuição de moléculas orgânicas no meio } \\
\text { interestelar, cometas, meteoritos e outros, por meio da } \\
\text { simulação de diferentes microambientes em cada cela. }\end{array}$ \\
\hline
\end{tabular}


O Brasil já participa de projetos com pequenos satélites, como o NanosatC-Br1, NanosatCBr2, AESP 14, Serpens, Conasat, Itasat-1, e Tancredo I e II do UbatubaSat, com apoio do Instituto Nacional de Pesquisas Espaciais (INPE) e apoio financeiro da Agencia Espacial Brasileira (AEB). Com isso, o objetivo de capacitação de recursos humanos para projetos de aplicação espacial tem sido atendido e o campo tem crescido muito no Brasil. Porém, nenhum deles ainda levou a bordo um experimento relacionado à astrobiologia, como os citados anteriormente, enviados por times da Europa e Estados Unidos. Esses avanços na tecnologia espacial brasileira de CubeSats e grande potencial para um contínuo crescimento, abrem portas para avanços também na área de astrobiologia, já que pequenos satélites são plataformas científicas muito interessantes para experimentos dessa área.

\subsubsection{Missões planetárias: Marte}

Durante séculos persistiu a crença popular de que Marte seria o planeta mais próximo da Terra contendo oceanos, continentes, vegetação e até estruturas complexas produzidas por civilizações de vida inteligente. Após décadas de esforços científicos, finalmente foi estabelecido que Marte possui uma atmosfera fina e composta majoritariamente de $\mathrm{CO}_{2}$, e que sua superfície é extremamente árida (70), se revelando um ambiente cada vez mais inóspito.

Em 1965, Mariner 4 foi a primeira missão robótica bem-sucedida à Marte, que confirmou com imagens a inexistência de oceanos, continentes ou vegetação, e mostrou uma superfície cheia de crateras, sugerindo um longo passado violento. Mariner 9, em órbita de Marte em 1971, realizava um mapeamento sistemático de sua superfície, quando trouxe imagens revolucionárias de redes de canais e afluentes que se assemelhavam fortemente a canais de escoamento e leitos de rios secos. Marte de repente voltou à vida: se há, ou já houve, água na sua superfície, então organismos também poderiam estar presentes.

Em 1975/76, as sondas Viking 1 e 2 foram as primeiras a pousar com sucesso e prover imagens e dados diretamente da superfície de Marte, ambas equipadas com câmeras, instrumentos meteorológicos e um laboratório em miniatura destinado a experimentos biológicos. Após anos de debate sobre os confusos resultados dos experimentos, o consenso foi de que as sondas não encontraram nenhum sinal de vida marciana, embora alguns autores ainda discutam que podem existir evidências de sinais de vida nos dados coletados.

Na década de 1990, o interesse na exploração de Marte ressurgiu e uma nova frota de sondas e satélites foram enviadas ao planeta vizinho nos últimos anos. Entre elas, a sonda Phoenix em 2008 usou instrumentos a bordo para procurar ambientes adequados para a vida microbiana e 
pesquisar a história da água em Marte. Dentre seus vários resultados, a sonda Phoenix confirmou a presença de água em forma de gelo (71), e a presença de $\sim 0,5 \%$ de percloratos no solo marciano. (72)

E a detecção de argilas na superfície de Marte, em 2011, confirmaram que bilhões de anos atrás suas condições ambientais permitiam uma maior habitabilidade. Como já mencionado, as argilas são minerais hidratados que se formam pelo intemperismo de rochas na presença de água líquida, o que indica um passado mais quente e úmido de nosso planeta vizinho. (24)

Em 2012, o rover Curiosity da sonda robótica espacial Mars Science Laboratory (MSL), pousou com sucesso em solo marciano. Seus objetivos gerais incluem investigar a habitabilidade de Marte, estudar seu clima e sua geologia, e coletar dados para uma futura missão tripulada para Marte. Dados têm sido fornecidos desde seu pouso até atualmente. (73), (74)

Em 2015, traços de compostos orgânicos foram detectados na Gale Crater, uma cratera de impacto marciana. Acredita-se que havia um grande lago enchendo essa cratera, a partir do qual sedimentos de $\sim 3,5$ bilhões de anos, com altas concentrações de lamitos, foram sendo depositados, formando a grande montanha que hoje existe no meio da cratera. Apesar de serem orgânicos clorados, que não são comumente encontrados na natureza terrestre, tais descobertas motivaram ainda mais a busca por assinaturas moleculares na superfície de Marte. (25)

E recentemente, em junho de 2018, foi anunciada uma nova descoberta da sonda Curiosity na mesma cratera: foram detectados compostos orgânicos (não clorados) e em maior concentração. (26) Novamente, tais compostos estão associados aos lamitos e confirmam o potencial das argilas de preservação de compostos orgânicos.

Futuras missões incluem a ExoMars da ESA, e a Mars 2020 da NASA, ambas previstas para pousar sondas na superfície de Marte em 2020. A ExoMars carregará instrumentos científicos, chamados coletivamente de Pasteur suite, dedicados à análise da composição mineral do solo, para estudar a habitabilidade do ambiente, e à busca por possíveis bioassinaturas. (75) A Mars 2020 tem os objetivos similares de investigar os processos e histórico geológicos da superfície de Marte, incluindo a análise de sua habitabilidade no passado, e potencial para a preservação de bioassinaturas em materiais geológicos. (76)

É por esses motivos que Marte parece ser o ambiente mais promissor de se encontrar bioassinaturas moleculares, e foi escolhido como foco neste trabalho. 


\subsection{MÉTODOS ESPECTROSCÓPICOS}

\subsubsection{Espectroscopia vibracional}

A espectroscopia vibracional é utilizada para investigar transições vibracionais (ou vibracionais/rotacionais em fase gasosa) de certa molécula. O número de modos vibracionais ativos fornecem informações a respeito de sua geometria molecular, e os valores das frequências dos modos vibracionais fornecem informações sobre a natureza das ligações químicas presentes.

Vibrações moleculares podem ocorrer por dois mecanismos principais: absorção de um quantum de luz e por espalhamento inelástico dos fótons, o que dá origem, respectivamente às técnicas de espectroscopia de absorção no infravermelho (IR) e espectroscopia de espalhamento Raman, principais técnicas utilizadas em espectroscopia vibracional.

O modelo do oscilador harmônico apresenta uma aproximação quase universal para a espectroscopia vibracional. Inicialmente considera-se moléculas como um conjunto de esferas com massa conectadas por molas sem massa, representando os átomos e suas ligações intramoleculares, respectivamente.

$\mathrm{O}$ caso mais simples seria de duas massas, $m_{A}$ e $m_{B}$, correspondentes a uma molécula diatômica A-B. O deslocamento, $x$, das esferas conectadas por uma mola com uma constante de força, $k$, é dado pela lei de Hooke:

$$
F_{x}=-k x^{2}
$$

Quanto maior for a força da ligação, maior é $k$. As energias potencial, $V$, e cinética, $T$, dependem então do quadrado do deslocamento desde a posição de equilíbrio:

$$
V=\frac{1}{2} k x^{2} \quad e \quad T=\frac{1}{2} \mu(\dot{x})^{2}
$$

Onde $\mu$ é a massa reduzida, definida por:

$$
\mu=\frac{m_{A} \cdot m_{B}}{m_{A}+m_{B}}
$$

Pela conservação de energia, a soma de V e T deve ser constante, tal que a soma de suas primeiras derivadas deve ser igual a zero, o que resulta na equação de movimento de Newton:

$$
\frac{d^{2} x}{d t^{2}}+\frac{k}{\mu} x=0
$$

A equação 14 representa a equação diferencial para um movimento harmônico com solução dada por uma função seno ou cosseno, dada por: 


$$
x=A \cdot \cos (\omega t+\varphi)
$$

Onde $A, \omega$ e $\varphi$ são amplitude, frequência angular e fase, respectivamente. Combinando a equação 15 com sua segunda derivada, obtemos:

$$
\frac{d^{2} x}{d t^{2}}+\omega^{2} \Delta x=0
$$

Comparando 16 com 14, obtemos:

$$
\omega=\sqrt{\frac{k}{\mu}}
$$

A equação 17 indica o esperado: a frequência angular da vibração harmônica aumenta com o aumento da força da ligação (ou constante da mola, nessa aproximação), e diminui com o aumento da massa dos átomos. De modo a expressar a frequência angular em número de onda $\left(\mathrm{cm}^{-1}\right)$, divide-se a equação 17 por $2 \pi c$, com $c$ em $\mathrm{cm} \cdot \mathrm{s}^{-1}$, obtendo:

$$
\tilde{v}=\frac{1}{2 \pi c} \sqrt{\frac{k}{\mu}}
$$

Em um sistema de coordenadas cartesianas, cada átomo pode ser deslocado nas direções x, y e z, correspondentes aos 3 graus de liberdade. Uma molécula não linear com $\mathrm{N}$ átomos possui, então, $3 \mathrm{~N}$ graus de liberdade, sendo 3 correspondentes a translações e 3 a rotações, resultando em $3 \mathrm{~N}-6$ graus de liberdade vibracionais. E uma molécula linear, com somente 2 graus de liberdade rotacionais, possui $3 \mathrm{~N}-5$ graus de liberdade vibracionais. (77)

No entanto, nem todas essas vibrações, denominadas modos normais de vibração, darão origem a transições vibracionais em ambos os espectros de absorção no IR e de espalhamento Raman. Dependendo da molécula, modos normais de vibração podem ser ativos e avaliadas por ambas as espectroscopias IR e Raman, ou somente em uma delas, e ambas as técnicas fornecem, em muitos casos, informações complementares.

\subsubsection{Espectroscopia de absorção no infravermelho}

O primeiro caso, absorção direta dos fótons, ocorre quando as moléculas são irradiadas com luz policromática que inclui fótons com energia igual à diferença de energia entre dois níveis vibracionais, $h v_{\mathrm{k}}$, o estado vibracional inicial (i, estado fundamental) e o final (f, primeiro estado excitado) (77):

$$
h v_{k}=h v_{f}-h v_{i}
$$


Como essas diferenças de energia são da ordem de 0.5 a 0.005 eV, luz com comprimentos de onda maiores que $2.5 \mu \mathrm{m}$ (na faixa do IR) é suficiente para induzir uma transição vibracional, mostrada no diagrama de energia da Figura 13.

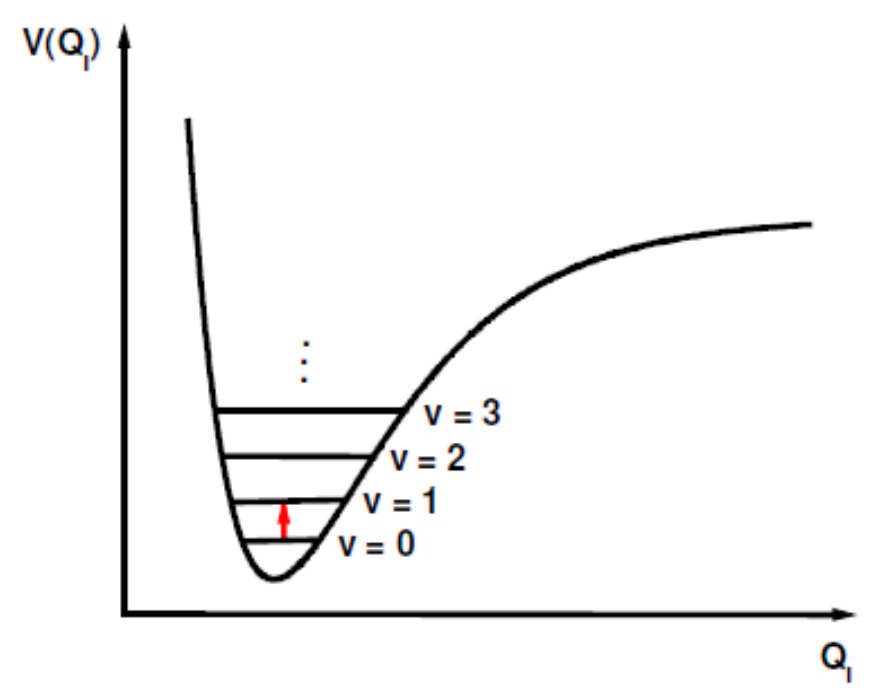

Figura 13 - Diagrama de energia mostrando a transição vibracional pela absorção de luz policromática no infravermelho.

Fonte: SIEBERT; HILDEBRANDT (77)

No entanto, nem todas essas vibrações, denominadas modos normais de vibração, darão origem a transições vibracionais no espectro IR. Isso é explicado pela regra de seleção específica que impõe que uma mudança no estado vibracional causada por absorção ou emissão de radiação só ocorre quando há uma variação no momento de dipolo elétrico da molécula após o deslocamento de seus átomos (equação 20). Se essa regra for cumprida, diz-se que a vibração é “ativa no IR". (32)

$$
\left(\frac{\partial \mu}{\partial Q_{\mathrm{i}}}\right)_{0} \neq 0
$$

Onde $\mu$ é o momento de dipolo elétrico, $Q_{i}$ é a coordenada normal associada ao i-ésimo modo normal da molécula. Nota-se que a molécula não precisa ter um momento de dipolo permanente, basta que haja uma variação no momento de dipolo (possivelmente a partir de zero), possibilitando, assim, seu acoplamento com o campo elétrico da radiação eletromagnética.

A intensidade da banda permitida é diretamente proporcional ao quadrado de $\partial \mu / \partial Q_{i}$, ou seja, quanto mais polarizadas forem as ligações da molécula, maior será a variação no $\mu$, e mais intensas serão suas bandas de absorção no IR.

O momento de dipolo elétrico de transição, responsável pela intensidade das transições espectroscópicas, é dado por: 


$$
\mu_{f i}=\int_{-\infty}^{+\infty} \Psi_{v f} * \hat{\mu} \Psi_{v i} d \tau
$$

Onde $\Psi_{v f}$ e $\Psi_{v i}$ representam as funções de onda vibracionais que correspondem aos estados inicial e final das respectivas transições, e $\hat{\mu}$ representa o operador de momento de dipolo elétrico. O quadrado do momento de transição, $\left|\mu_{f i}\right|^{2}$, está diretamente relacionado com a chamada absortividade molar, que pode ser obtida experimentalmente.

O tratamento quântico dessa aproximação harmônica, analisando a expressão do momento de dipolo de transição, dá origem a uma regra específica de seleção. Esta regra determina que as transições vibracionais são permitidas quando envolvem níveis de energia separados por $\Delta v= \pm 1$, onde $\Delta v=+1$ corresponde a uma absorção e $\Delta v=-1$ corresponde a uma emissão. Isso surge porque se $\Delta v \neq \pm 1$, o momento de dipolo de transição é zero.

O equipamento disponível no LNLS é um espectrômetro FTIR (Infravermelho por Transformada de Fourier), e o modo utilizado foi de absorção por transmissão. A base de qualquer espectrômetro FTIR é o interferômetro de Michelson com um espelho móvel (esquema na Figura 14). A radiação de uma fonte é dividida em dois feixes, sendo cada um idealmente 50\% do original, no "beamsplitter" (divisor de feixe). Um dos feixes, A, segue em direção ao espelho de posição fixa no qual reflete de volta para o "beamsplitter", onde parte deste feixe reflete de volta para a fonte e parte vai para o detector. O outro feixe, B, vai em direção ao espelho móvel, no qual também reflete, parte de volta para a fonte e parte para o detector. Se a posição do espelho móvel é tal que o feixe B percorre a mesma distância que o feixe A antes de chegar ao detector $(\delta=n \lambda$, onde $n=0,1,2, \ldots)$, então os dois feixes estão em fase, ocorrendo interferência construtiva e, neste caso, a energia que chega ao detector será maximizada. Por outro lado, se a posição do espelho móvel for tal que o caminho do feixe B seja diferente daquele do feixe A por $(n+1) \lambda / 2$, então os dois feixes estarão $90^{\circ}$ fora de fase, ocorrendo interferência destrutiva e a energia que chega no detector, nesse caso, será minimizada. Portanto, à medida que o espelho móvel percorre determinada distância, um interferograma é formado.

A intensidade da radiação que chega no detector, $I(\delta, \tilde{v})$, varia como uma função cosseno da diferença de caminho percorrido, ou retardação óptica, $\delta$, e do número de onda da radiação, $\tilde{v}=1 / \lambda$ :

$$
I(\delta, \tilde{v})=I(\tilde{v})[1+\cos (2 \pi \tilde{v} \delta)]
$$


Onde $I(\tilde{v})$ é o espectro a ser determinado. Assim, o interferômetro detecta a presença no sinal de uma componente em número de onda e a converte para uma variação em intensidade da radiação chegando ao detector.

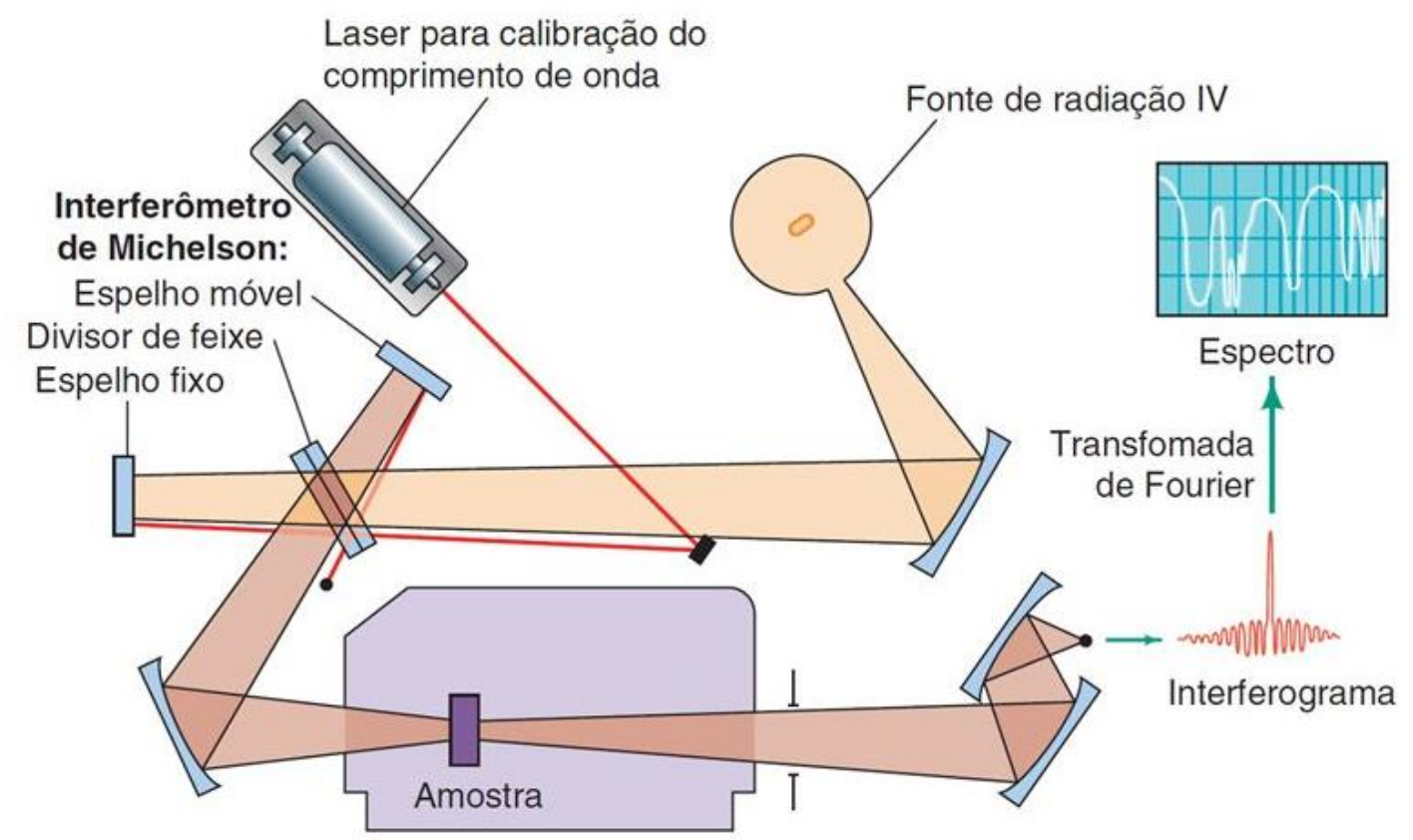

Figura 14 - Esquema de funcionamento de um equipamento FTIR.

Fonte: FLORENZANO (78)

Quando uma fonte de radiação policromática é usada, o interferograma pode ser interpretado como a soma das contribuições de todas as componentes do sinal e, então, para uma fonte contínua de infravermelho, a intensidade total chegando no detector, $I(\delta)$, é dada por:

$$
I(\delta)=\int_{0}^{\infty} I(\delta, \tilde{v}) d \tilde{v}=\int_{0}^{\infty} I(\tilde{v})[1+\cos (2 \pi \tilde{v} \delta)] d \tilde{v}
$$

A transformada de Fourier dessa equação nos fornece o resultado desejado, $I(\tilde{v})$, em termos da quantidade medida, $I(\delta)$ :

$$
I(\tilde{v})=4 \int_{0}^{\infty}\left[I(\delta)-\frac{1}{2} I(\delta=0)\right] \cos (2 \pi \tilde{v} \delta) d \delta
$$

Um interferograma típico de uma fonte policromática no infravermelho é mostrado na Figura 15. Nota-se que quando $\delta=0$, as ondas estão em fase e à medida que o espelho se move, a partir de $\delta$, em ambas as direções, $\mathrm{I}(\delta)$ varia de acordo com as contribuições das várias frequências que podem estar em fase ou fora de fase. E o sinal no espectro final de IR é mostrado na Figura 15, direita, onde a ordenada representa a quantidade de luz absorvida, geralmente expressa em unidades de absorbância. 

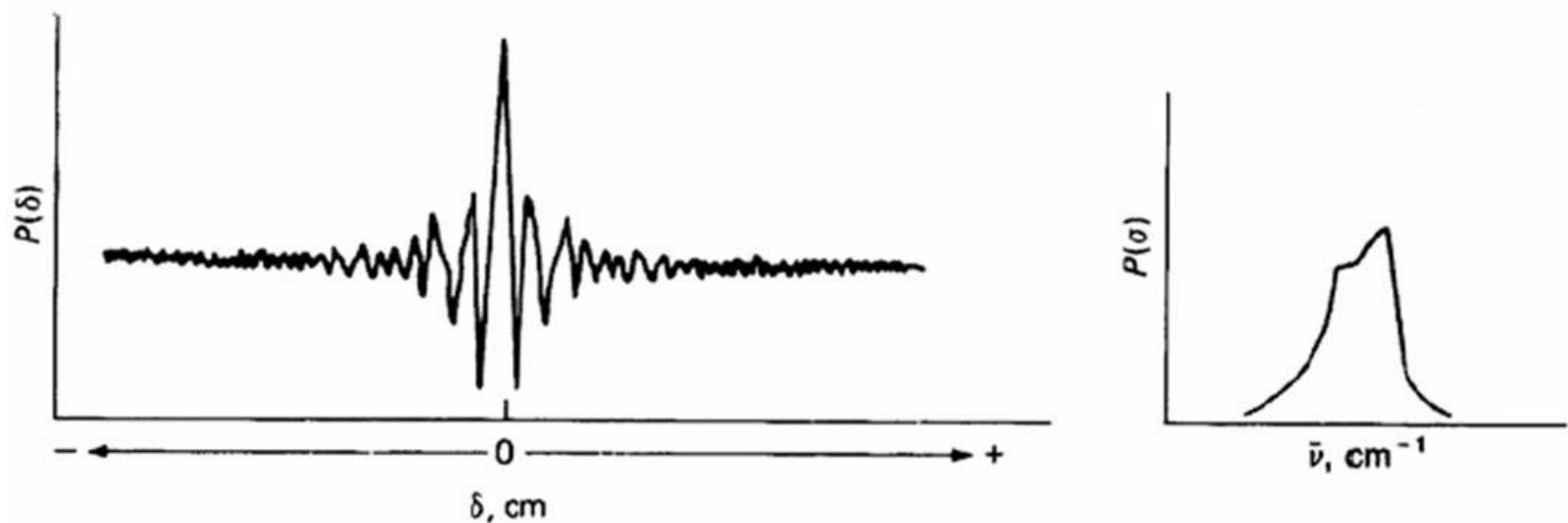

Figura 15 - Esquerda: Interferograma típico obtido em equipamento FTIR. Direita: espectro IR obtido após transformada de Fourier.

Fonte: Adaptada de TRANSFORMADA... (79)

\subsubsection{Espalhamento Raman}

O segundo caso, espalhamento inelástico dos fótons, ocorre quando as moléculas são irradiadas com luz monocromática, colimada e coerente. A grande maioria dos fótons incidentes na amostra sofre espalhamento elástico, ou seja, são espalhados sem variação na frequência inicial $\left(v_{0}\right)$ - o chamado espalhamento Rayleigh. Uma pequena parcela dos fótons $\left(\sim 1 \mathrm{em} 10^{6}\right)$ interage com a amostra e sofre um espalhamento inelástico, com aumento ou diminuição na frequência $\left(v_{R}=v_{0} \pm \mathrm{d} v\right)$. Pela lei de conservação de energia, essa diferença corresponde à mudança de energia dos estados vibracionais da molécula (final - inicial), de acordo com a equação 25. Este espalhamento inelástico foi descoberto pelo cientista indiano C. V. Raman em 1928 e, por isso, é denotado como "efeito Raman”. (77)

$$
h v_{0}-\left|h v_{R}\right|=h v_{f}-h v_{i}
$$

O ganho ou perda em energia está relacionado a uma variação na polarizabilidade da molécula induzida pelo campo elétrico da radiação eletromagnética, e corresponde à frequência de uma excitação vibracional da molécula, que está relacionada à sua estrutura molecular, incluindo tipos de ligações e grupos funcionais. Este fenômeno, chamado espalhamento Raman, envolve uma transição entre um estado eletrônico e um estado virtual de maior energia, mas com energia abaixo do estado eletrônico excitado subsequente, e rápido retorno para o estado eletrônico original, mas diferente estado roto-vibracional. Na Figura 16, um diagrama de níveis de energia mostra os estados envolvidos no espalhamento Raman, em contraste com a absorção no UV-Vis, que envolve diferentes estados eletrônicos, e no infravermelho, que envolve somente estados roto-vibracionais do mesmo estado eletrônico. (80) 
A espectroscopia por espalhamento Raman é, então, baseada na detecção dos fótons espalhados inelasticamente após interação com a densidade eletrônica polarizável das moléculas da amostra, e medida dos deslocamentos em energia com relação aos fótons incidentes, $\mathrm{v}$, medidos em número de onda, $\mathrm{cm}^{-1}$. Se o fóton cede energia aos elétrons da molécula para excitá-los do estado roto-vibrônico fundamental (nível de menor energia rotacional e vibracional do estado eletrônico fundamental) a um estado roto-vibracional superior, o fóton espalhado e detectado pelo equipamento tem energia menor que a inicial $\left(v_{0}-\right.$ $v$ ) - chamado espalhamento Raman Stokes. Se o fóton ganhou energia dos elétrons da molécula fazendo-os retornar de um estado roto-vibracional excitado ao estado fundamental, o fóton espalhado tem energia maior que a inicial $\left(v_{0}+v\right)$. Este processo, chamado de espalhamento Raman Anti-Stokes, é muito menos intenso que o Stokes, dado que, à temperatura ambiente, a energia termal é menor do que as energias da maioria dos modos normais, então a população de moléculas em $v=0$ é muito maior do que a em $v=1(\sim 1 \%)$ sob condições normais. $\mathrm{Na}$ Figura 17 diagramas de energia mostram os processos de espalhamento.

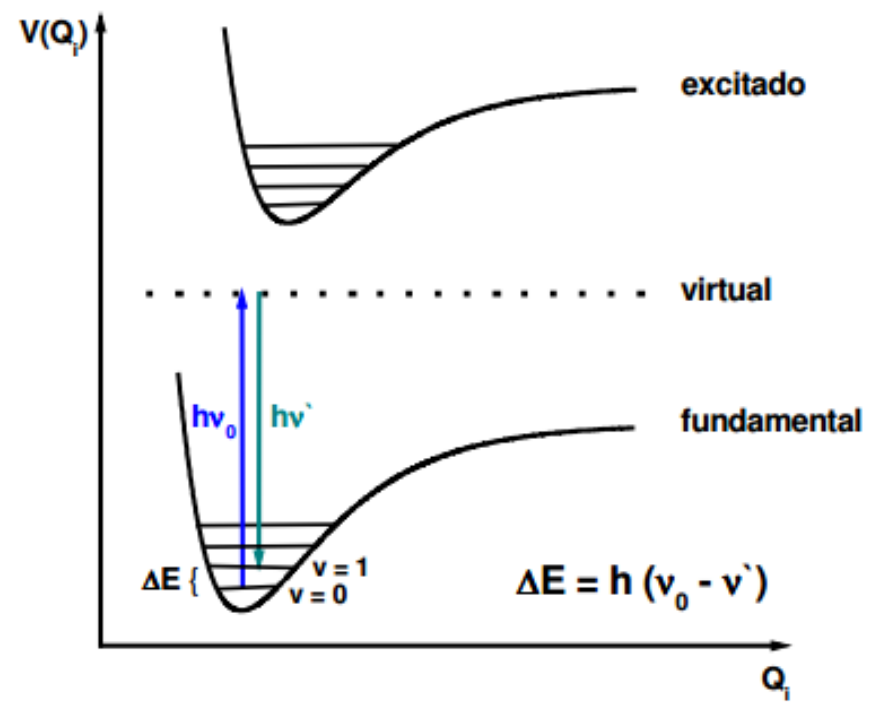

Figura 16 - Diagrama de energia mostrando a transição vibracional envolvida na espectroscopia Raman. Fonte: SIEBERT; HILDEBRANDT (77) 


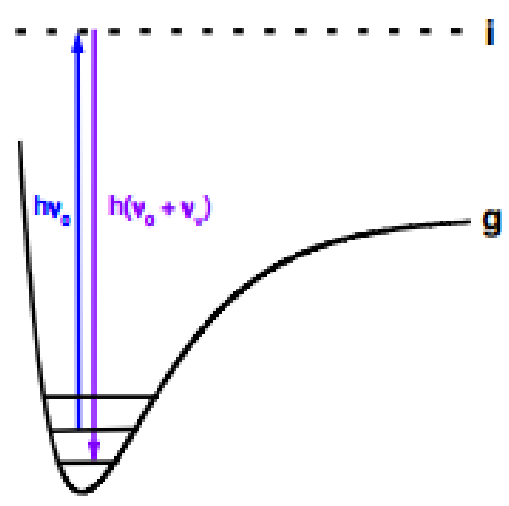

anti-Stokes

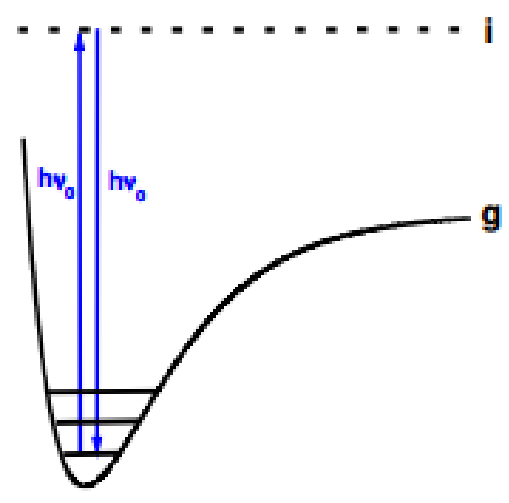

Rayleigh

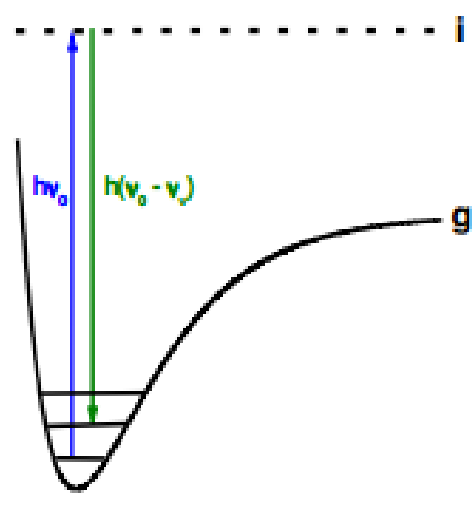

Stokes

Figura 17 - Diagramas de energia dos estados envolvidos nos espalhamentos elástico (Rayleigh) e inelásticos (Stokes e anti-Stokes).

Fonte: SIEBERT; HILDEBRANDT (77)

Além da regra de seleção vibracional, pela qual as transições são permitidas quando envolvem níveis de energia separados por $\Delta v= \pm 1$, válida para a aproximação harmônica, há uma outra regra de seleção específica para o fenômeno Raman, equação 26, que exige uma variação na polarizabilidade eletrônica da molécula com o pequeno deslocamento da coordenada q em torno da posição de equilíbrio.

$$
\left(\frac{\partial \alpha}{\partial Q_{i}}\right)_{0} \neq 0
$$

Onde $\alpha$ é a polarizabilidade eletrônica da molécula e $Q_{i}$ é a coordenada normal associada ao i-ésimo modo normal da molécula.

A polarizabilidade pode ser considerada como uma medida da facilidade de deformação da nuvem eletrônica da molécula na presença de um campo elétrico. Portanto, moléculas contendo átomos com $\mathrm{Z}$ elevado (grande quantidade de elétrons e baixo potencial de ionização) envolvendo ligações químicas covalentes pouco polarizadas, devem possuir valores elevados para $\alpha$.

O momento de dipolo $\left(\vec{\mu}_{\text {ind }}\right)$ induzido na molécula pelo campo elétrico da luz $(\vec{E})$ oscilando a uma frequência $v_{0}$, depende da amplitude do campo elétrico e da polarizabilidade da molécula, de acordo com:

$$
\vec{\mu}_{\text {ind }}=\vec{\alpha}(v) \vec{E}=\vec{\alpha}(v) \cdot \vec{E}_{0} \cos \left(2 \pi v_{0} t\right)
$$

E a polarizabilidade varia com o tempo, descrevendo a resposta da distribuição eletrônica aos movimentos do núcleo que oscila com a frequência do modo normal $\left(v_{k}\right)$, de acordo com:

$$
\vec{\alpha}(v)=\vec{\alpha}_{0}\left(v_{0}\right)+\left(\frac{\partial \vec{\alpha}}{\partial Q_{k}}\right)_{0}\left(2 \pi v_{k} t\right)
$$


Combinando as equações 27 e 28, e rearranjando os termos, obtemos a equação 15.

$\vec{\mu}_{\text {ind }}=\vec{E}_{0}\left[\vec{\alpha}_{0} \cos \left(2 \pi v_{0} t\right)+\left(\frac{\partial \vec{\alpha}}{\partial Q_{k}}\right)_{0} Q_{k} \cos \left[2 \pi\left(v_{0}+v_{k}\right) t\right]+\left(\frac{\partial \vec{\alpha}}{\partial Q_{k}}\right)_{0} Q_{k} \cos \left[2 \pi\left(v_{0}-v_{k}\right) t\right]\right]$

A somatória do lado direito da equação 29 inclui três termos correspondentes às polarizabilidades que dependem de diferentes frequências, a da radiação incidente $v_{0}$ (correspondente ao espalhamento Rayleigh) e as frequências $\left(v_{0}-v_{k}\right)$ e $\left(v_{0}+v_{k}\right)$, correspondentes aos espalhamentos Raman Stokes e Anti-Stokes, respectivamente. (77)

Um exemplo de espectro Raman é mostrado na Figura 18.

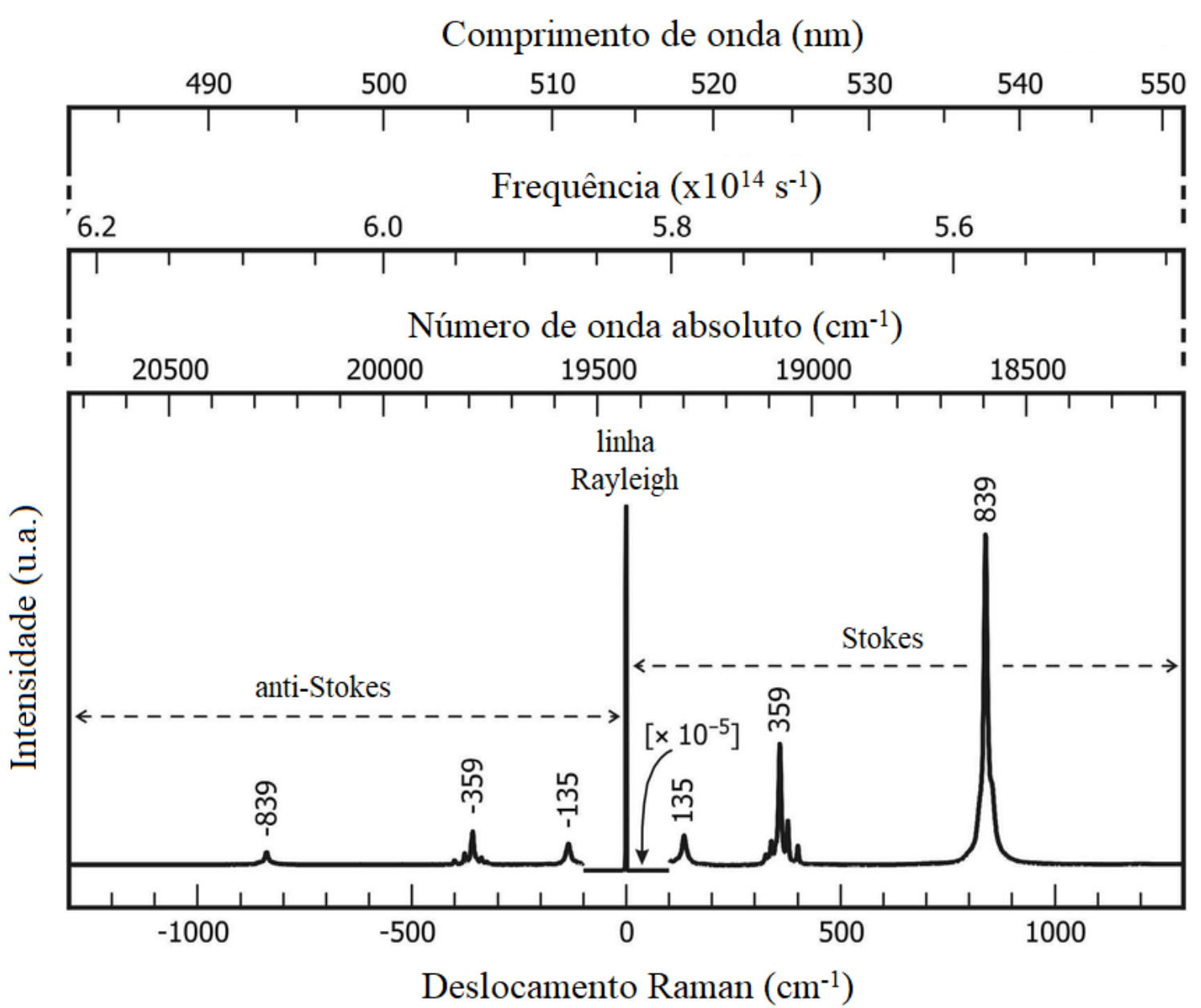

Figura 18 - Espectro Raman do cromato de chumbo (PbCrO4) obtido com laser de 514,5 nm. Comparação entre as linhas Stokes e Anti-Stokes, com intensidades diferentes e o mesmo valor de deslocamento Raman em módulo. Três escalas adicionais acima para elucidar a relação entre número de onda absoluto e relativo, frequências e comprimento de onda.

Fonte: NASDALA et al. (81)

O eixo y representa a contagem de fótons, ou intensidade, em unidades arbitrárias, que depende do momento de dipolo induzido na molécula e é inversamente proporcional ao comprimento de onda do fóton incidente, de acordo com a equação 30. E o eixo x representa a 
diferença de energia dos fótons espalhados e medidos pelo detector com relação aos fótons do laser incidente, chamada de deslocamento Raman, ou Raman shift, dado em $\mathrm{cm}^{-1}$, e calculado pela equação 31 , onde $\lambda_{0}$ é o comprimento de onda do laser incidente e $\lambda_{1}$ é o comprimento de onda do fóton espalhado.

$$
\begin{gathered}
I_{\text {Raman }}=\left(\vec{\mu}_{\text {ind }}\right)^{2} \rightarrow I_{\text {Raman }} \propto 1 / \lambda^{4} \\
\Delta \omega=\left(\frac{1}{\lambda_{0}}-\frac{1}{\lambda_{1}}\right) \rightarrow \Delta \omega\left(\mathrm{cm}^{-1}\right)=\left(\frac{1}{\lambda_{0}(\mathrm{~nm})}-\frac{1}{\lambda_{1}(\mathrm{~nm})}\right) \cdot \frac{10^{7} \mathrm{~nm}}{\mathrm{~cm}}
\end{gathered}
$$

Um grande problema na prática é que Raman produz sinais tipicamente várias ordens de grandeza menos intensos que a fluorescência, a qual gera um intenso e largo background no espectro, podendo mascarar os picos Raman da mesma amostra. Uma solução tem sido utilizar lasers de comprimentos de onda menores, de modo a obter sinais Raman mais intensos.

\subsubsection{Espectroscopia eletrônica no ultravioleta-visível}

Quando a luz incidente em uma amostra tem comprimentos de onda na faixa do ultravioleta e do visível (UV-Vis), os fótons absorvidos pelas moléculas da amostra possuem energia suficiente para causar nas moléculas transições eletrônicas (mais precisamente vibrônicas, pois são acompanhadas por transições vibracionais e rotacionais, de menor energia) (Figura 19), diferentemente das transições por absorção no infravermelho, que são somente vibracionais. Portanto, a espectroscopia no UV-Vis fornece informações sobre a estrutura eletrônica das moléculas constituintes da amostra de interesse.

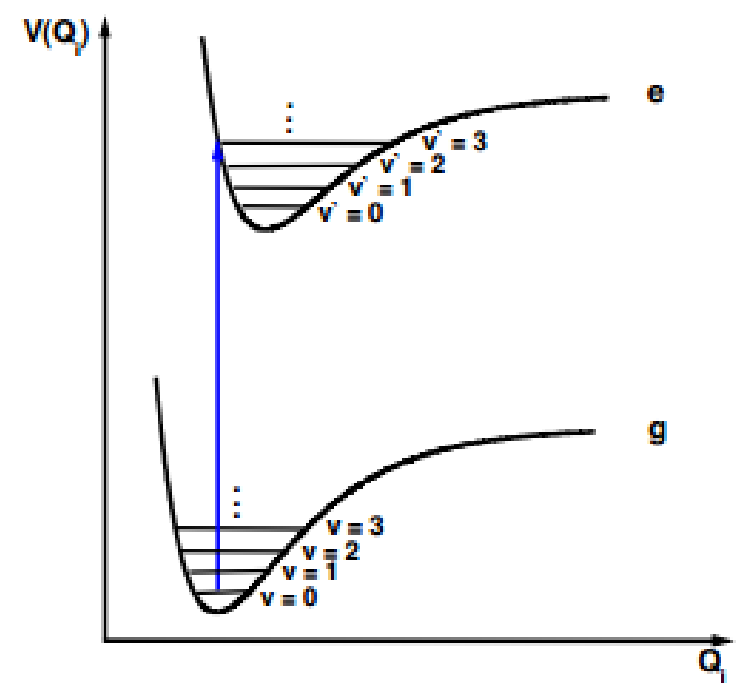

Figura 19 - Diagrama de energia mostrando a transição vibrônica pela absorção de luz policromática no UV-vis. Fonte: SIEBERT; HILDEBRANDT. (77) 
A intensidade da luz transmitida pela amostra é atenuada exponencialmente em função da distância percorrida pelos fótons, expressa pela Lei da Absorção de Lambert (equação 32), que se aplica somente a meios transparentes sólidos ou líquidos.

$$
I_{t}(\lambda)=I_{i}(\lambda) \exp (-\alpha(\lambda) b)
$$

Onde $I_{t}$ é a intensidade da luz transmitida pela amostra, $I_{i}$ é a intensidade da luz incidente, $\alpha(\lambda)$ é o coeficiente de absorção e b é o caminho ótico percorrido pela luz.

Para amostras absorventes em solventes ou substratos transparentes, o coeficiente de absorção é proporcional à concentração do soluto, o que fornece a generalização da Lei de BeerLambert (equação 33), consistente para a maioria dos materiais sólidos e líquidos onde os efeitos de reflexão na superfície são mínimos.

$$
A=\log \left(I_{i} / I_{t}\right)=\alpha(\lambda) b=b C \varepsilon
$$

Onde $A$ é a absorbância do material, $\varepsilon$ é o coeficiente de absortividade molar da amostra $\left[\mathrm{L} \cdot \mathrm{mol}^{-1} \cdot \mathrm{cm}^{-1}\right.$ ] e C é a concentração da amostra [mol.L $\left.\mathrm{L}^{-1}\right]$.

Porém, para materiais cujas partículas são pequenas em comparação com a seção de choque do feixe, mas grandes em comparação com o comprimento de onda, o fenômeno de difração também ocorre. A luz incidente pode sofrer reflexão especular, na qual o ângulo do feixe refletido é igual ao do incidente (Figura 20, esquerda), como ocorre com espelhos, por exemplo. Ou ela pode sofrer reflexão difusa, fenômeno resultante da reflexão, refração, difração e absorção por partículas orientadas em todas as direções e, portanto, os feixes refletidos têm ângulos diferentes do feixe incidente (Figura 20, direita). Em amostras em pó, com partículas randomicamente orientadas e com dimensões como descritas, parte da luz incidente - que penetrou no material e interagiu com suas moléculas - é refletida em várias direções levando informações sobre as propriedades da amostra.

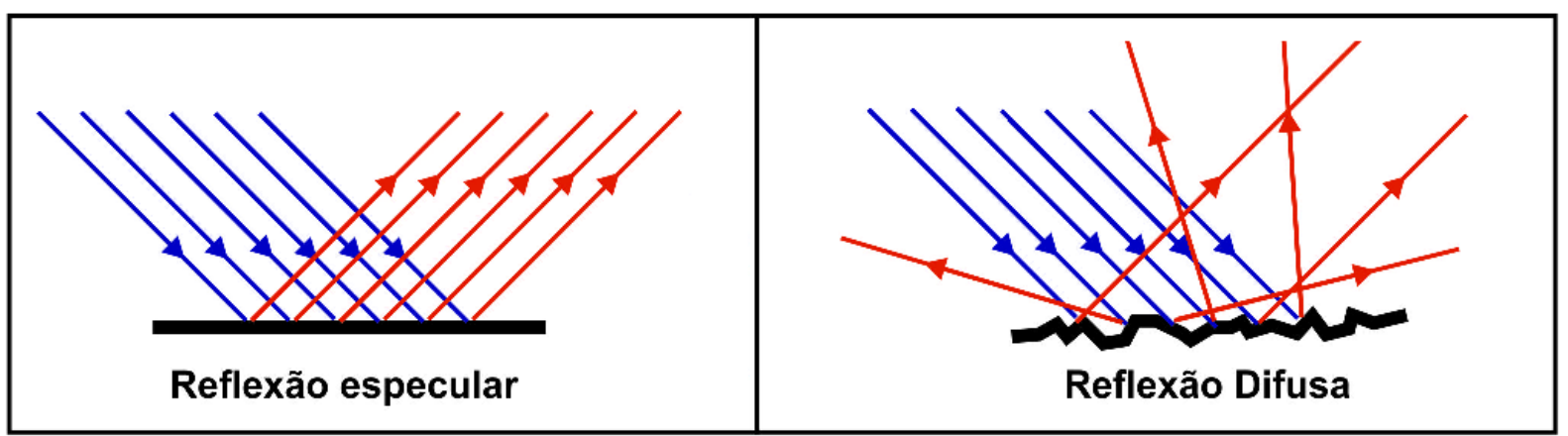

Figura 20 - Reflexões especular (esquerda) e difusa (direita). Fonte: SPECULAR... (82) 
$\mathrm{Na}$ espectroscopia por reflectância difusa, essa luz difusamente espalhada é coletada, geralmente com o auxílio de uma esfera integradora que combina todos os feixes em diferentes direções, e é direcionada à ótica do detector (fotomultiplicadora ou espectrógrafo). O sinal coletado é então processado para recuperar a reflectância $(\mathrm{R})$ da amostra, que é definida como a razão entre o fluxo de radiação refletida e o fluxo de radiação incidente. Pode-se então construir uma curva de reflectância espectral ao comparar tal medida com uma amostra padrão que reflete totalmente a luz incidente.

A teoria de Kubelka-Munk prevê que, para uma camada de material de espessura $d$ sendo irradiada com um fluxo de radiação difusa monocromática na direção $-x$, representado por $I$, a relação entre este fluxo e aquele que está sendo espalhado de volta pelo material (na direção $+x)$, representado por $J$, em uma fina camada de espessura $d x$ é dada pelo sistema de equações diferenciais:

$$
-\frac{d I}{d x}=-(K+S) I+S J \quad e \quad \frac{d J}{d x}=-(K+S) J+S I
$$

Onde $K$ e $S$ representam, respectivamente, os coeficientes de absorção e de espalhamento da luz por unidade de comprimento. Resolvendo o sistema, pode-se chegar à "Função de KubelkaMunk", expressa por:

$$
\frac{K}{S}=\frac{\left(1-R_{\infty}\right)^{2}}{2 R_{\infty}} \equiv F\left(R_{\infty}\right)
$$

Onde $R_{\infty}$ representa a reflectância de uma camada de material totalmente opaca (ou seja, com uma espessura tal que a luz não a atravesse). (83)

\subsubsection{Aplicações em missões espaciais}

A espectroscopia Raman tem ganhado destaque na área de astrobiologia por ser uma técnica de não-contato e minimamente destrutiva, que não necessita de preparo (químico ou mecânico) das amostras, e oferece resolução espacial e alta sensitividade para a detecção e caracterização in situ tanto de compostos orgânicos quanto inorgânicos. Tais características a tornam uma técnica ideal para a detecção de bioassinaturas e análise dos minerais associados, na Terra e em outras superfícies planetárias no nosso sistema solar.

É uma potencial alternativa a métodos destrutivos utilizados em missões espaciais, como a Pirólise acoplada à Cromatografia Gasosa/Espectrometria de Massas (Py-GC/MS), utilizada pelo instrumento SAM (na Curiosity) para detectar compostos orgânicos em Marte. E é por estas e outras vantagens que a espectroscopia Raman foi selecionada por 
ambas as missões ExoMars e Mars 2020 das agências espaciais europeia (ESA) e estadunidense (NASA), respectivamente. (84)-(86)

Uma desvantagem da utilização desta técnica em experimentos de astrobiologia é a maior dificuldade para realizar medidas in situ tanto em laboratório, quanto nas missões em balões estratosféricos e em CubeSats. Por isso, nesse trabalho, foram realizadas duas medidas, uma antes e uma após a irradiação das amostras, o que fornece informações incompletas no caso de estudos fotoquímicos de biomoléculas.

Por outro lado, espectroscopia no UV-Vis-NIR por reflectância pôde ser utilizada em laboratório para medidas in situ e em tempo real nos experimentos de irradiação (descritos nas próximas seções). E espectroscopia no UV-Vis-NIR por absorção já foi e será novamente utilizada em missões espaciais em CubeSat, como apresentado anteriormente, com a utilização de mini espectrômetros portáteis e de baixo consumo de energia. Tais medidas espectroscópicas, in situ e em tempo real, forneceram importantes informações para estudos detalhados da fotoestabilidade de biomoléculas em ambientes extremos.

Entretanto, espectroscopia na faixa do infravermelho médio (Mid-IR, 4000-1000 cm-1) teria a vantagem, em relação à no UV-Vis, de fornecer padrões específicos característicos das principais funções orgânicas, sendo, portanto, mais informativo para compostos orgânicos. Espectroscopia nesta faixa ainda não foi utilizada em missões espaciais, porém, o CubeSat OREOcube, em fase de construção, enviará um espectrômetro no IR.

Além disso, em missões planetárias em busca de informações em superfícies extraterrestres a espectroscopia por reflectância (assim como a espectroscopia Raman) tem vantagem sobre a espectroscopia por absorção, devido à não necessidade de preparos complexos das amostras. 


\section{OBJETIVOS}

\subsection{GERAL}

Investigar a detectabilidade de biomoléculas e a fotoestabilidade de suas assinaturas espectroscópicas em ambientes extraterrestres simulados, utilizando câmaras de simulação e métodos espectroscópicos, incluindo técnicas in situ. Os resultados fornecem informações sobre a resposta dessas biomoléculas a diversas condições ambientais, permitindo testar seu potencial como bioassinatura, bem como otimizar as técnicas e procedimentos para sua detecção em ambiente espacial real.

De forma mais imediata, os resultados estão sendo utilizados para embasar experimentos de astrobiologia, em pequena escala e baixo custo, que foram e/ou ainda serão enviados em missões para o espaço em balões estratosféricos e em CubeSat, ambos em andamento ou preparação pelo grupo de pesquisas no qual o projeto está inserido. As simulações auxiliam na escolha das biomoléculas a serem enviadas e na definição dos parâmetros de medida, otimizando a qualidade dos dados, e produzindo dados de controle para a missão.

E um objetivo secundário desse projeto é a contribuição para o desenvolvimento da tecnologia espacial brasileira de pequenos satélites, que é uma área relativamente nova e ainda não foi realizada em parceria com pesquisadores da área de astrobiologia.

\subsection{ESPECÍFICOS}

- Delinear as condições a serem simuladas, baseadas nos ambientes de interesse (espacial, de baixa órbita, e de superfície planetária marciana);

- Escolher as diferentes biomoléculas-modelo a serem testadas como bioassinaturas, baseado na literatura;

- Verificar em laboratório a resposta espectroscópica das biomoléculas escolhidas (utilizando espectroscopia no UV-Vis, FTIR, Raman);

- Comparar diferentes técnicas de simulação (uniparamétrica, multiparamétrica e utilizando luz síncrotron);

- Realizar experimentos de simulação em laboratório e analisar resultados com medidas in situ (reflectância no UV-Vis), e ex situ de bancada (espalhamento Raman, transmitância no UV-Vis e IR); 
- Participar na elaboração e análise de experimentos baseados em balões estratosféricos;

- Participar na elaboração de experimentos baseados em CubeSats. 


\section{MATERIAIS E MÉTODOS}

\subsection{BIOMOLÉCULAS E SUBSTRATOS}

A resposta espectroscópica de diversas amostras de biomoléculas pertencentes a diferentes classes, além de alguns substratos inorgânicos, foi pesquisada na literatura e testada antes dos experimentos de simulação, utilizando equipamentos de bancada. As biomoléculas e substratos testados foram escolhidos de acordo com a disponibilidade e importância astrobiológica (considerando os constituintes da vida terrestre e os constituintes de superfícies extraterrestres). E, então, um maior foco foi dado aos pigmentos biológicos clorofila a e $\beta$-caroteno, pela sua detectabilidade com os métodos espectroscópicos disponíveis (discutidas na seção 4), tanto puros quanto misturados com os substratos de interesse.

Foram utilizadas amostras-padrão disponíveis no LNLS pertencentes ao grupo de pesquisa no qual o projeto está inserido, e também amostras fornecidas pelo pesquisador colaborador Prof. Dr. Fabio Rodrigues do Instituto de Química da USP-SP. As amostras utilizadas nos experimentos e seu fornecimento estão detalhadas na Tabela 3.

Tabela 3 - Amostras utilizadas em todos experimentos, suas classes e fornecimento.

\begin{tabular}{|c|c|c|}
\hline Amostra & Classe / Descrição & Fornecedor \\
\hline \multirow[t]{2}{*}{$\beta$-caroteno } & Pigmento biológico puro & Sigma Aldrich (C9750) \\
\hline & Pigmento biológico natural da cenoura & $\begin{array}{c}\text { Allied Biotech } \\
\text { (Lote: } 801 \mathrm{E} 22055)\end{array}$ \\
\hline Clorofila a & $\begin{array}{c}\text { Pigmento biológico natural, da cianobactéria } \\
\text { Spirulina (Arthospira platenis) }\end{array}$ & Florien (Lote: 059199) \\
\hline DL-cisteína & Amino ácido & Sigma Aldrich (861677) \\
\hline L-cistina & Dímero de amino ácido & Sigma Aldrich (C8755) \\
\hline Fulereno $\mathrm{C}_{60}$ & Fulereno & Sigma Aldrich (483036) \\
\hline Guanina & Base nucleotídica & Sigma Aldrich (G11950) \\
\hline $\begin{array}{l}\text { Deinococcus } \\
\text { Radiodurans }\end{array}$ & $\begin{array}{l}\text { Células da bactéria liofilizadas } \\
(0,045 \mathrm{~mm})\end{array}$ & $\begin{array}{l}\text { Laboratório Quimiosfera } \\
\text { (IQ-USP) }\end{array}$ \\
\hline Hemina & Porfirina (de bovinos) & Sigma Aldrich (H9039) \\
\hline ATP & 5 'trifosfato de adenosina & Sigma Aldrich (A2383) \\
\hline Ácido fumárico & Ácido carboxílico & Sigma Aldrich (47910) \\
\hline Caulinita $\left(\mathrm{KG}_{\mathrm{a}-2}\right)$ & \multirow[t]{2}{*}{ Argilas (filossilicato de alumínio) } & \multirow{2}{*}{$\begin{array}{l}\text { The Clay Minerals } \\
\text { Society }\end{array}$} \\
\hline $\begin{array}{l}\text { Montmorilonita } \\
\left(\mathrm{SY}_{\mathrm{n}-1}\right)\end{array}$ & & \\
\hline JSC-Mars 1A & Simulante do Regolito Marciano & \multirow{2}{*}{$\begin{array}{l}\text { Orbital Technologies } \\
\text { Corporation (Orbitec) }\end{array}$} \\
\hline JSC-1A Lunar & Simulante do Regolito Lunar & \\
\hline Goetita & Mineral de ferro $(\mathrm{FeO}(\mathrm{OH}))$ & Sigma Aldrich (71063) \\
\hline Sulfato de Magnésio & Sal identificado na superfície de Marte & Sigma Aldrich (M7506) \\
\hline Sulfato de Bário & Padrão branco - reflectância difusa & Sigma Aldrich (243353) \\
\hline
\end{tabular}




\subsection{PREPARO DE AMOSTRAS}

\subsubsection{Deposição por evaporação de solvente}

Foram preparadas soluções supersaturadas das amostras de pigmentos biológicos em etanol P.A.. Foram selecionados quadrados de $\sim 1 \mathrm{~cm}^{2}$ de área por $\sim 1 \mathrm{~mm}$ de espessura tanto de porcelana, os quais foram cobertos com papel alumínio, quanto de silício. As soluções foram depositadas nas superfícies de $\mathrm{Al}$ e $\mathrm{Si}$ com o auxílio de micropipetas e em etapas, utilizando cerca de $3 \mu \mathrm{L}$ por etapa, até que se formasse um filme visível dos pigmentos. O substrato foi deixado sobre bancada após cada etapa de adição de solução para a secagem do solvente.

\subsubsection{Pastilhas}

Para as medidas de reflectância, as amostras não precisam ser finas, pois a luz não as atravessa. Portanto, foram produzidas pastilhas das amostras sólidas (em pó) tanto puras quanto misturadas com substratos inorgânicos.

Todas as amostras em pó foram filtradas em membranas de $40 \mu \mathrm{m}$ e as misturas foram homogeneizadas com auxílio de almofariz e pistilo. As pastilhas (de 4 ou $13 \mathrm{~mm}$ de diâmetro) foram, então, produzidas com auxílio de pastilhadores e prensa manual. Exemplos dos equipamentos utilizados são mostrados nas fotos da Figura 21.
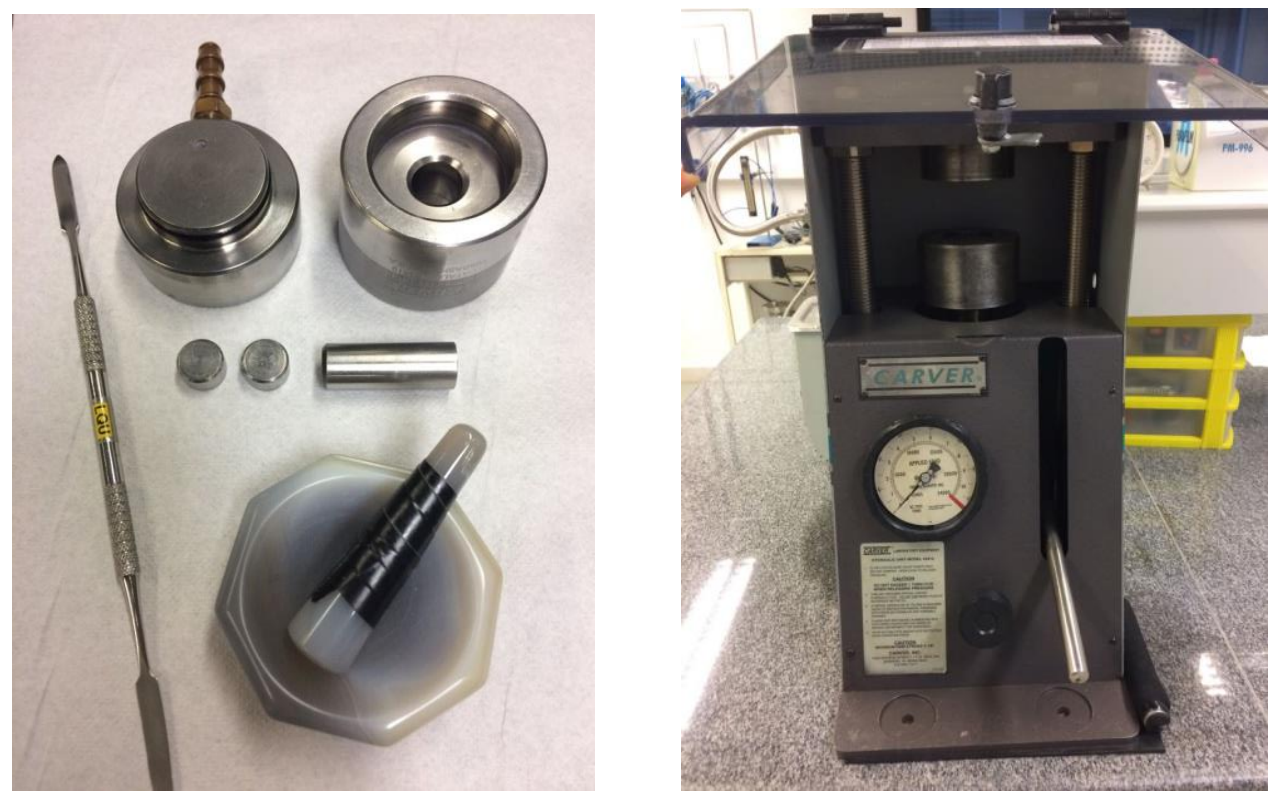

Figura 21 - Esquerda: foto do pastilhador de $13 \mathrm{~mm}$ (cima) e almofariz + pistilo de porcelana (baixo). Direita: foto da prensa manual utilizada para produzir as pastilhas. 


\subsubsection{Filmes (aerógrafo)}

Para as medidas de transmitância, as amostras devem ser finas, pois a luz deve atravessá-las. Portanto, foram produzidos filmes das amostras sólidas (em pó) puras com o auxílio de um "Kit Aerógrafo" da Western ${ }^{\circledR}$ : dispositivo utilizado para pintura em artes comerciais e ilustração, no qual a tinta é ejetada na forma de spray.

No caso, é feita uma solução da amostra no solvente orgânico mais apropriado (clorofórmio para o $\beta$-caroteno e etanol para a clorofila a) e adicionada ao aerógrafo no lugar da tinta. $\mathrm{O}$ aerógrafo é posicionado e fixado verticalmente em suporte universal, conectado à linha de nitrogênio da capela. O suporte onde o filme será produzido (lamínula de vidro) é posicionado abaixo do aerógrafo sobre uma chapa de aquecimento, para auxiliar na evaporação do solvente. A alavanca de operação é acionada e presa com fita para que o fluxo de nitrogênio arraste a solução de forma constante até que a solução se esgote. O esquema de produção e detalhe do aerógrafo são mostrados na Figura 22. A lamínula é deixada sobre a chapa de aquecimento por cerca de 10 minutos para a evaporação completa do solvente.

As lamínulas foram previamente limpas de modo sistemático: molho de água com detergente em ultrassom por 25 minutos, banho básico (10\% de KOH em isopropanol) por 20 minutos, banho ácido $\left(10 \%\right.$ de $\left.\mathrm{HNO}_{3}\right)$ por 20 minutos, limpeza com isopropanol e secagem com fluxo de nitrogênio.
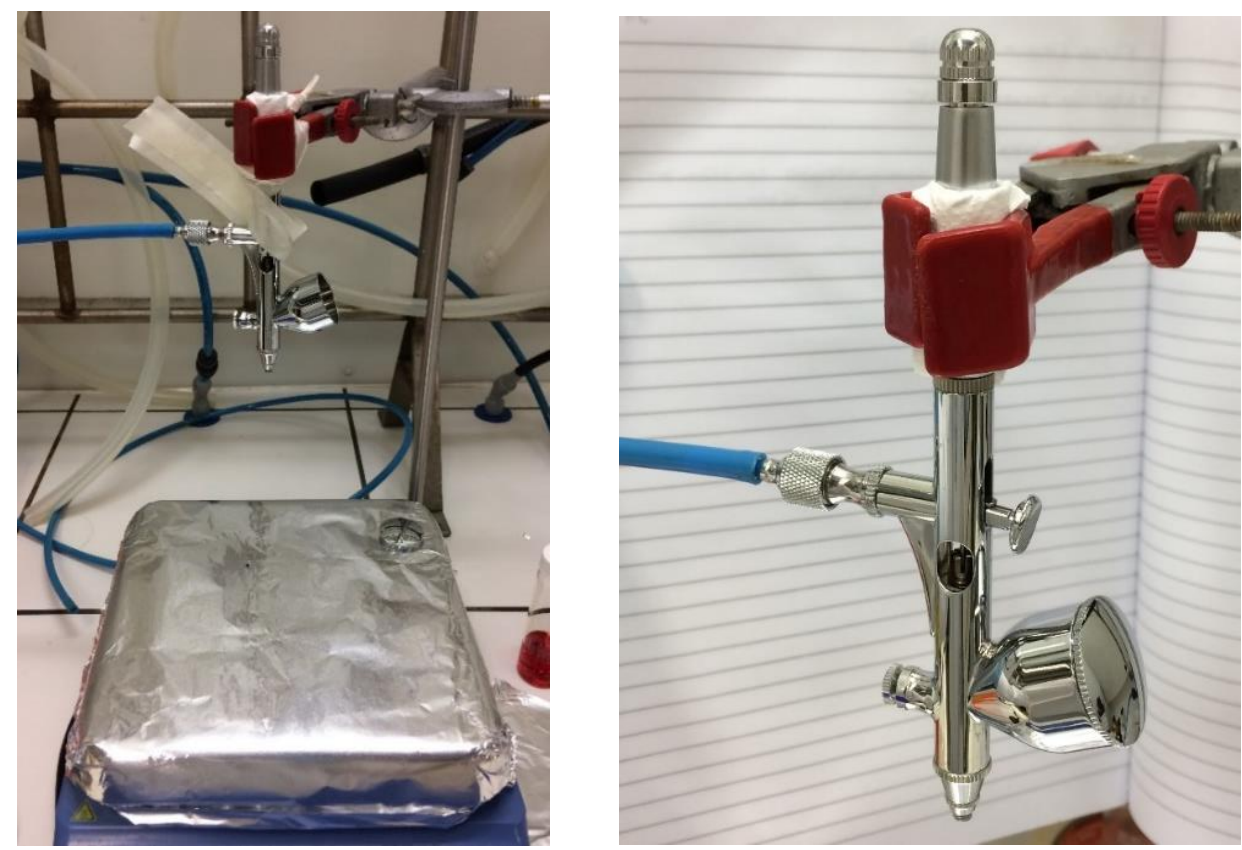

Figura 22 - Esquerda: esquema de produção dos filmes. Direita: aerógrafo em detalhe. Fonte: Obtida pela autora 
Diversos filmes foram produzidos variando as condições e parâmetros do experimento: distância do aerógrafo até a lamínula, pressão da válvula de nitrogênio, volume de solução utilizado, temperatura da chapa de aquecimento e ajuste de fluxo do aerógrafo. Os tempos de produção de cada filme variavam entre 2 e 20 minutos. A área dos filmes foi fixada em um quadrado de 1,5 x 1,5 cm com o auxílio de fitas, e foram medidas as massas da lamínula limpa e da lamínula com o filme, para que fosse possível o cálculo da espessura do filme.

\subsection{EXPERIMENTOS EM LABORATÓRIO}

\subsubsection{Irradiação UVC}

Como detalhado na introdução, a faixa do UVC pode induzir fotodissociação de moléculas orgânicas e induzir variações espectrais que podem dificultar e até impossibilitar sua detecção. Neste primeiro experimento, foi feita uma comparação entre os pigmentos biológicos selecionados (clorofila a e $\beta$-caroteno) sem a adição de substratos inorgânicos. Foram utilizados o $\beta$-caroteno puro e a clorofila a extraída da Spirulina (em etanol).

Irradiações de filmes finos dos pigmentos (preparo descrito na seção 3.2.3) foram feitas utilizando uma "caixa de irradiação" feita de acrílico e contendo duas lâmpadas germicidas que emitem luz na faixa do ultravioleta C (UVC) (F8T5/-GL da Orion, potência 8 W).

As amostras foram analisadas, utilizando equipamentos de bancada, por espectroscopia de transmissão no infravermelho (FTIR, modelo Spectrum Two da marca PerkinElmer), e transmissão no UV-Vis (da marca Agilent), ambos disponíveis em laboratório químico do LNLS, mostrados na Figura 23.

Os espectros FTIR foram coletados de 500 a $4000 \mathrm{~cm}^{-1}$, com média de 16 varreduras, e os espectros UV-Vis foram coletados de 200 a $900 \mathrm{~nm}$. Para ambas as técnicas foi utilizado como espectro de referência (branco) o próprio substrato limpo (lamínula de vidro).

As amostras foram, então, posicionadas abaixo das lâmpadas (entre as duas), a uma distância de $\sim 13.6 \mathrm{~cm}$ (Figura 24), e irradiadas durante intervalos de tempo determinados até completar 4 horas de irradiação. Após cada intervalo de tempo, a lâmpada foi desligada e as amostras retiradas para nova análise espectroscópica. 

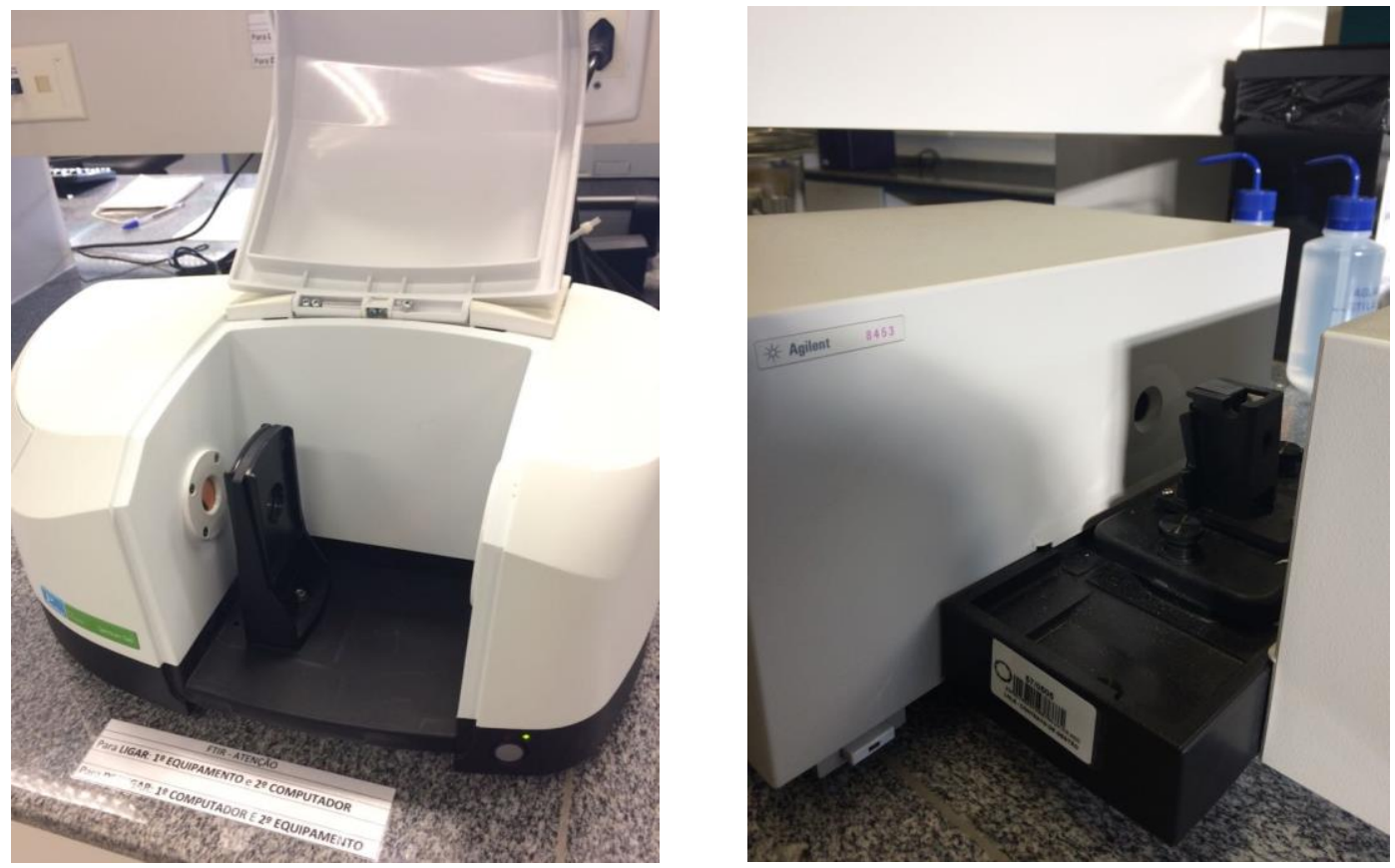

Figura 23 - Equipamentos de bancada no modo de transmissão utilizados na caracterização dos filmes finos irradiados. Esquerda: FTIR. Direita: UV-Vis.

Fonte: Obtida pela autora
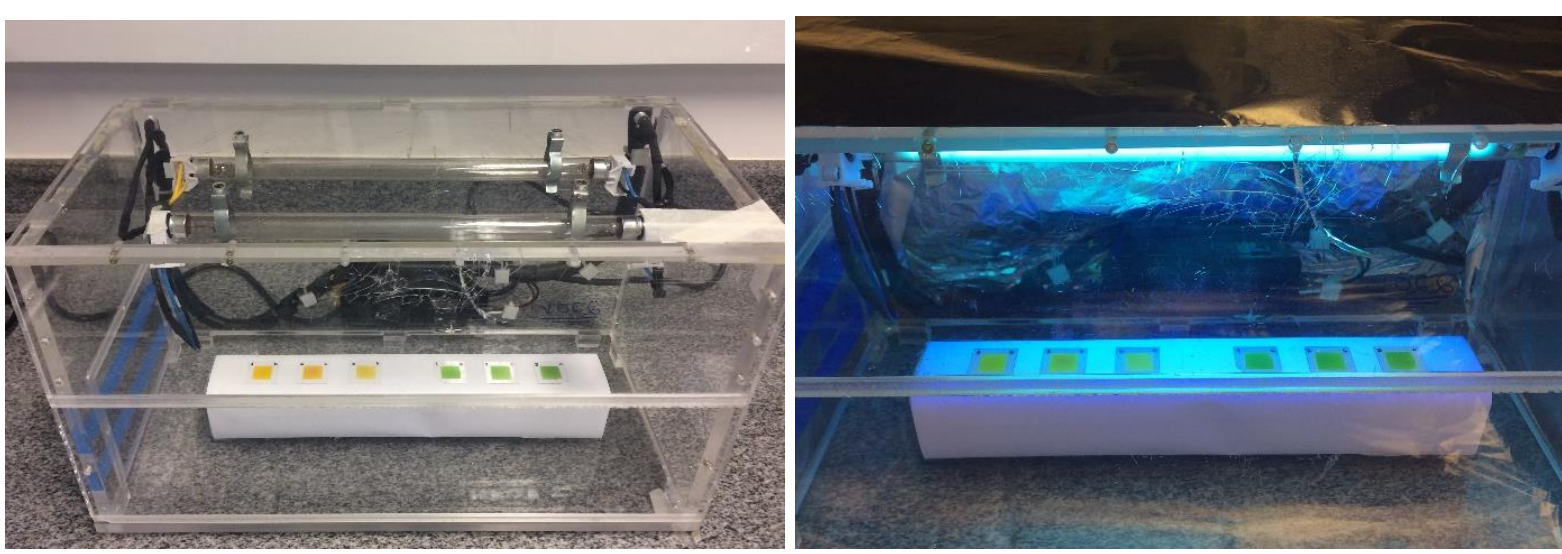

Figura 24 - Filmes das amostras dentro da caixa de irradiação contendo duas lâmpadas germicidas (UVC), apagadas (esquerda) e acesas (direita).

Fonte: Obtida pela autora

\subsubsection{AstroCam}

A Câmara de Simulação de Ambientes Espaciais e Planetários (AstroCam) é uma câmara de simulação multiparamétrica, mostrada na Figura 25, construída em 2011 pelo Dr. Douglas Galante (orientador do presente projeto) em seu Pós-Doutoramento, como um dos instrumentos centrais de pesquisa do NAP/Astrobio do Instituto de Astronomia Geofísica e Ciências Atmosféricas da USP. Nesta câmara é possível trabalhar com vácuo, diferentes fontes e fluxos de radiação (UV, partículas e outras), variando temperatura, pressão e composição gasosa, o 
que permite simular ambientes extraterrestres, como outros planetas, satélites, cometas, asteroides e o meio interestelar, além da Terra primitiva (prebiótica).

Experimentos de simulação Marciana foram conduzidos utilizando a AstroCam. O pigmento $\beta$-caroteno (da cenoura) foi irradiado em forma de pastilha em condições ambientais que se assemelham às condições da superfície de Marte, detalhadas na Tabela 4. Um criostato da marca ARS foi utilizado para abaixar a temperatura dentro da câmara até $210 \mathrm{~K}$. Uma bomba mecânica seca da marca Adixen foi utilizada para abaixar a pressão até em torno de 8 mbar. $\mathrm{E}$ tubos contendo sílica gel foram utilizados nos momentos de purga da câmara para assegurar uma baixa umidade relativa.

Tabela 4 - Comparação entre as condições ambientais da superfície de Marte e das atingidas em simulação na AstroCam.

\begin{tabular}{c|c|c}
\hline Parâmetro & $\begin{array}{c}\text { Superfície de Marte } \\
\text { (Medidos pela Curiosity) }\end{array}$ & AstroCam $^{\mathbf{b}}$ \\
\hline Pressão (mbar) & $7,3-9,2$ & $\sim 8$ \\
\hline Temperatura (K) & 240 (superfície) $/ 233(\mathrm{ar})$ & 210 \\
\hline Umidade relativa (\%) & $\sim 0$ & $\sim 0$ \\
\hline Radiação & Calculados $^{\mathbf{c}}$ & Medidos $^{\mathbf{b}}$ \\
\hline UVA $\left(\mathrm{W} / \mathrm{m}^{2}\right)$ & $38,39(315-400 \mathrm{~nm})$ & $27,6(365 \mathrm{~nm})$ \\
\hline UVB $\left(\mathrm{W} / \mathrm{m}^{2}\right)$ & $8,38(280-315 \mathrm{~nm})$ & $43,0(312 \mathrm{~nm})$ \\
\hline UVC $\left(\mathrm{W} / \mathrm{m}^{2}\right)$ & $3,18(200-280 \mathrm{~nm})$ & $5,34(254 \mathrm{~nm})$ \\
\hline UV total $\left(\mathrm{W} / \mathrm{m}^{2}\right)$ & 50,6 & 86,6 \\
\hline
\end{tabular}

a Valores medidos pelo instrumento "Rover Environmental Monitoring Station" do "Mars Science Laboratory" a bordo do rover Curiosity (NASA). (41)

${ }^{\mathrm{b}}$ Medidos pelos próprios equipamentos utilizados na AstroCam.

${ }^{c}$ Valores calculados de modelo teórico (estimado como $43 \%$ da constante solar na Terra). (87) Fonte: Adaptada pela autora

A foto da direita da Figura 25 mostra a fonte de radiação UV desacoplada da AstroCam. Trata-se de uma lâmpada de alta-pressão de Xenônio, Oriel Full Spectrum 1000W da marca Newport. Um espectro similar ao espectro solar recebido pela Terra, sem a absorção da atmosfera, pode ser produzido quando a luz emitida por essa fonte de UV passa por um filtro de $6 \mathrm{~cm}$ de água - para remover a intensa irradiância acima de $1100 \mathrm{~nm}$ (NIR) -, e por um filtro AM0 (Air Mass null) - para reduzir a intensa irradiância da lâmpada na região de 800 a 1100 $\mathrm{nm}$ e modelar o espectro. Um radiômetro foi utilizado para medir a irradiância da fonte nas faixas do UVA, UVB e UVC. 

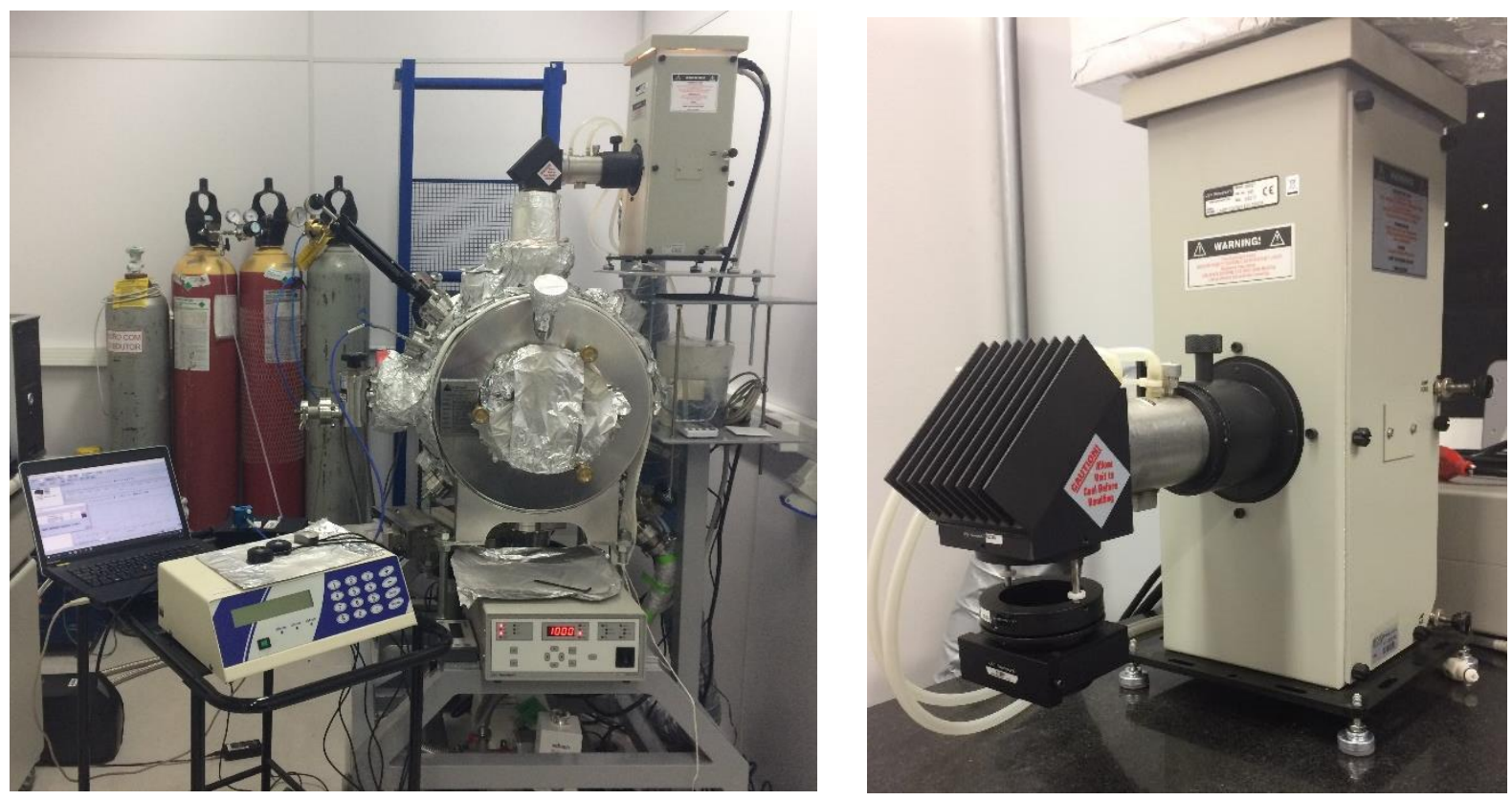

Figura 25 - Foto da Câmara de Simulação de Ambientes Espaciais e Planetários (AstroCam) em funcionamento (esquerda) e do Simulador Solar desacoplado dela (direita).

Fonte: Obtida pela autora

As mudanças nas biomoléculas expostas ao ambiente simulado foram analisadas in situ e em tempo real através de espectroscopia no UV-Vis por reflectância. Foi utilizada uma sonda de reflectância: fibra bifurcada da marca Ocean Optics, modelo QR600-7-SR125BX, tipo UV-SR, com diâmetro interno de $600 \mu \mathrm{m}$ e feita de alumínio, apropriada para ser utilizada em câmaras a vácuo (Figura 26, esquerda). A sonda foi acoplada a um manipulador de modo a fazer um ângulo de 45 graus com a pastilha da amostra, colada no porta-amostras com fita carbono (Figura 26, direita). A fonte utilizada para a espectroscopia foi a própria lâmpada de irradiação da AstroCam, o espectrômetro utilizado foi do modelo QE65000 da marca Ocean Optics, que trabalha na faixa de 200 a $1000 \mathrm{~nm}$, e a fibra ótica conectando a sonda ao espectrômetro foi do modelo QP300-1-SR, do tipo SR (Solar Resistant), e diâmetro de 300 m, também da Ocean Optics. Os espectros foram coletados durante a irradiação e salvos a cada 30 segundos, com tempo de aquisição de 500 ms e média de 10 varreduras. 

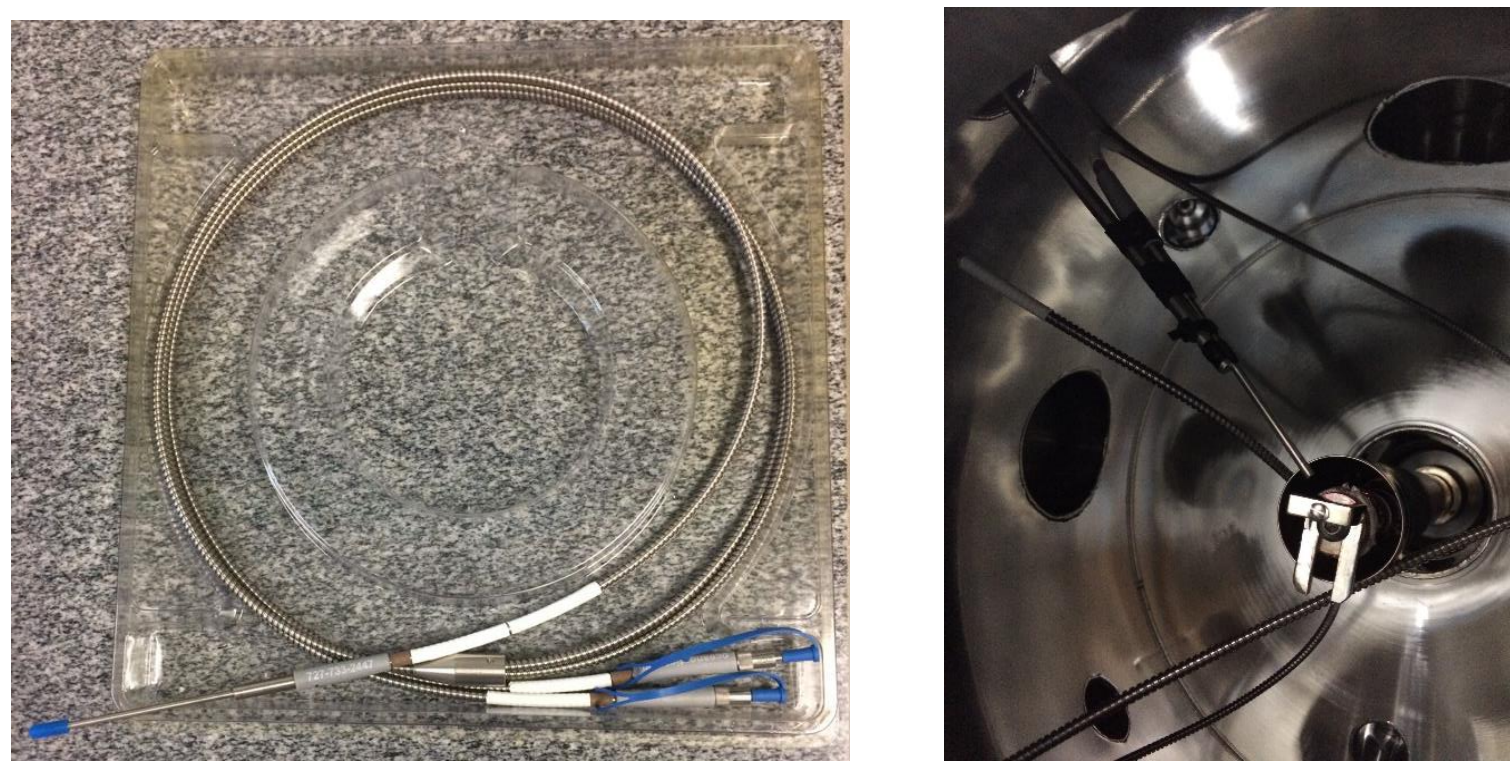

Figura 26 - Foto da parte de dentro da câmara da AstroCam mostrando o setup montado para as medidas de reflectância in situ utilizando uma sonda de reflectância.

Fonte: Obtida pela autora

\subsubsection{Radiação síncrotron - Linha de luz TGM (LNLS)}

As biomoléculas utilizadas neste experimento foram os pigmentos clorofila a (Spirulina) e $\beta$-caroteno (da cenoura). Foram preparadas pastilhas de $4 \mathrm{~mm}$ de diâmetro das misturas físicas, como descrito na seção 3.2.2. A Tabela 5 mostra em detalhes as concentrações utilizadas no preparo das pastilhas, cada uma com cerca de $20 \mathrm{mg}$. Além disso, foram preparadas pastilhas dos substratos puros, para irradiá-los e para utilizar seus espectros como branco (espectro de referência) para os espectros de reflectância das misturas. Pó de diamante foi utilizado porque apresenta um pico Raman fino e invariável em aproximadamente $1333 \mathrm{~cm}^{-1}$, devido às ligações C-C em sítios tetragonais. Além disso, é quimicamente inerte e mecanicamente robusto, o que o torna um ótimo padrão interno para quantificação em espectros Raman, ainda mais para experimentos envolvendo irradiação das amostras. (88) Apenas às misturas de substratos com $\beta$-caroteno foi adicionado o pó de diamante com este fim, pois este pigmento apresenta espectro característico por espectroscopia Raman, diferentemente da clorofila a que apresenta somente uma alta fluorescência sem picos característicos por esta técnica. Além disso, pelos mesmos motivos supracitados, o pó de diamante foi selecionado para "diluir opticamente" as amostras, ou seja, evitar a saturação dos espectros de absorção, para ser possível a visualização dos efeitos da irradiação somente nos pigmentos puros. 
Tabela 5 - Concentrações utilizadas no preparo das pastilhas para irradiação na linha TGM.

\begin{tabular}{c|c|c|c}
\hline Substrato & $\begin{array}{c}{[\boldsymbol{\beta} \text {-caroteno] }} \\
(\% \text { em massa) }\end{array}$ & $\begin{array}{c}\text { [Pó de diamante] } \\
\text { (\% em massa) }\end{array}$ & $\begin{array}{c}{[\text { Clorofila a] }} \\
(\% \text { em massa) }\end{array}$ \\
\hline Caulinita $\left(\mathrm{KG}_{\mathrm{a}-2)}\right)$ & 25 & 25 & 30 \\
\hline Montmorilonita $\left(\mathrm{SY}_{\mathrm{n}-1}\right)$ & 30 & 30 & 25 \\
\hline JSC-Mars 1A & 20 & 20 & 30 \\
\hline JSC-1A Lunar & 20 & 20 & 25 \\
\hline "Amostra pura" & 30 & 70 & 30 \\
\hline
\end{tabular}

Fonte: Elaborada pela autora

As pastilhas produzidas foram coladas no porta-amostras de alumínio com fita de carbono (Figura 27, esquerda e centro). Os porta-amostras foram colocados na câmara experimental da linha TGM e as pastilhas foram irradiadas, uma por vez, utilizando o feixe branco (policromático) da radiação síncrotron (Figura 27, direita). A câmara experimental foi mantida a uma pressão da ordem de $10^{-7}$ mbar e a temperatura ambiente durante as irradiações.

As análises de degradação das amostras foram feitas por reflectância difusa in situ, de acordo com o esquema da Figura 28. Foi utilizando como espectro de referência (branco) o próprio substrato puro no caso de irradiação das misturas, e sulfato de bário no caso de irradiação dos substratos puros. O espectrômetro utilizado é o QE65000 da marca Ocean Optics, e a fibra ótica CPATCH-2752615, do tipo UV-VIS, diâmetro de 600 m, também da Ocean Optics. Os espectros foram coletados durante a irradiação e salvos a cada 10 segundos, com tempo de aquisição e número de varreduras variando para cada amostra.
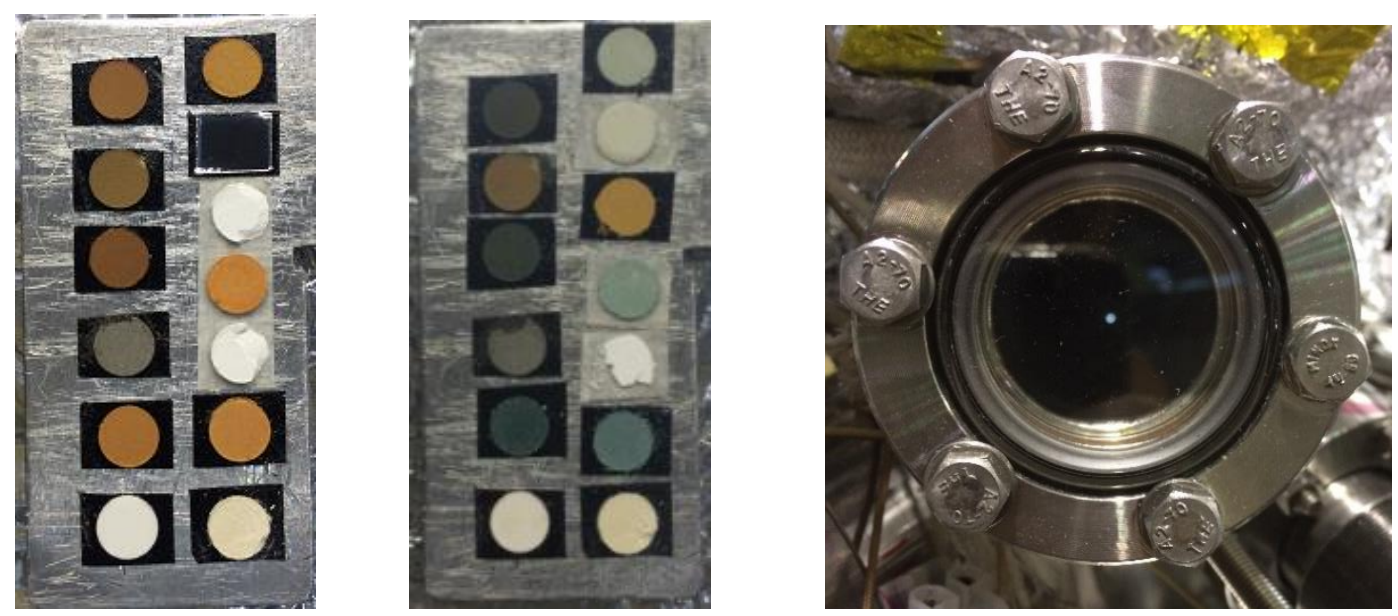

Figura 27 - Esquerda: porta-amostras de alumínio com pastilhas das amostras de $\beta$-caroteno. Centro: portaamostras de alumínio com pastilhas das amostras de Clorofila a. Direita: feixe de luz síncrotron irradiando uma das amostras dentro da câmara experimental da TGM.

Fonte: Obtida pela autora 


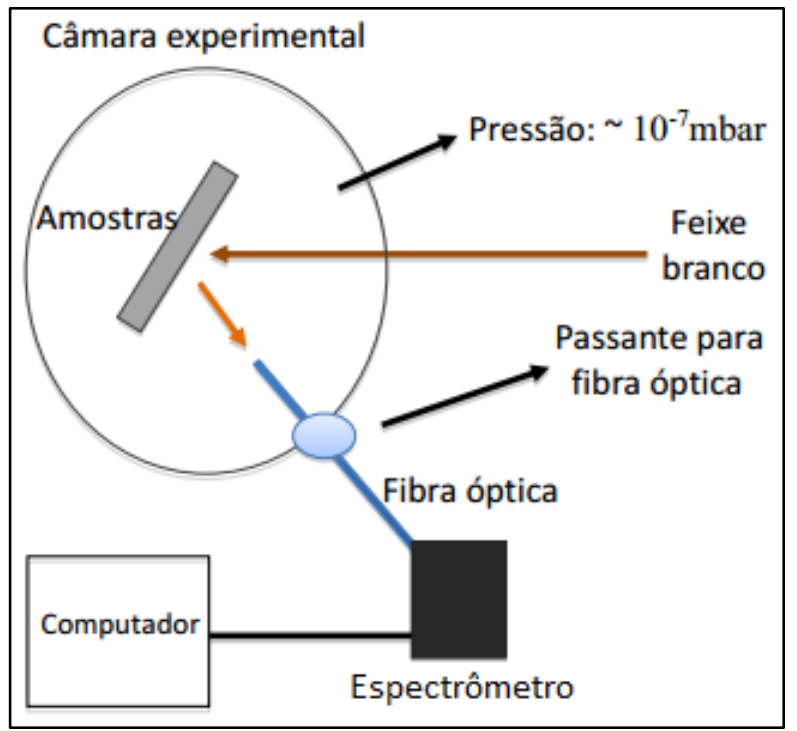

Figura 28 - Esquema da análise in situ por reflectância no UV-vis da degradação por irradiação com radiação síncrotron, feita na estação experimental da linha de luz TGM.

Fonte: Adaptada de GALLO (89)

E as amostras de $\beta$-caroteno também foram analisadas ex situ por espectroscopia Raman, antes e após a irradiação total. O equipamento disponível no LNLS é um espectrômetro microRaman da Reninshaw inVia (Figura 29). O laser de excitação utilizado foi o de $785 \mathrm{~nm} 300 \mathrm{~mW}$, focalizado nas amostras por uma lente de $5 \mathrm{x}$ de aumento.
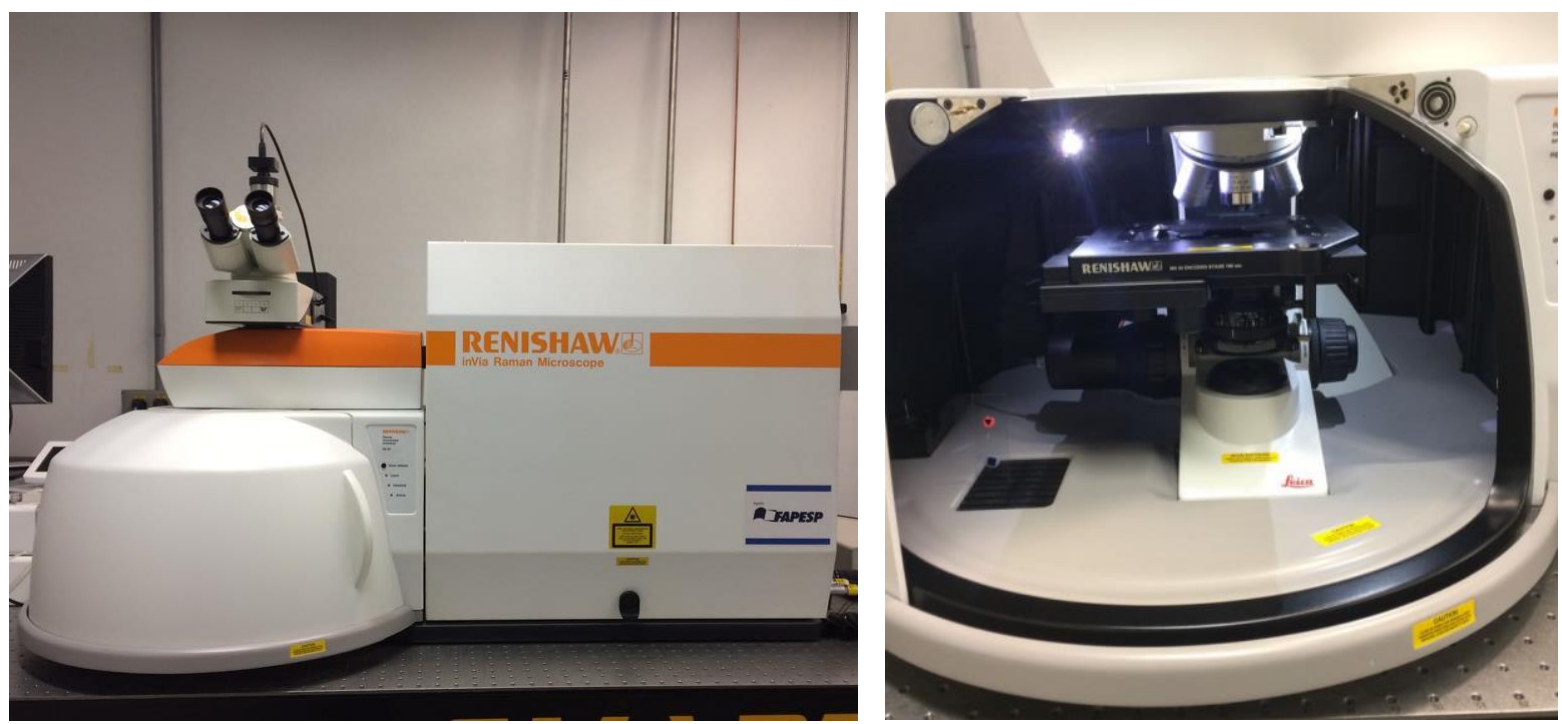

Figura 29 - Esquerda: espectrômetro micro-Raman disponível no LNLS. Direita: detalhe do interior do equipamento.

Fonte: Obtida pela autora 
Além disso, para ser possível o cálculo dos fluxos de radiação UV que chegam nas amostras, leituras de fluxo na linha de luz antes e após as irradiações foram feitas utilizando um fotodiodo do modelo SXUV100 do fabricante Opto Diode (calibrado pelo NIST).

\subsection{EXPERIMENTOS NA ESTRATOSFERA: balões de alta-altitude}

O projeto mais recente desse grupo é o desenvolvimento das Sondas Garatéa, que significa "Busca-vidas" em tupi-guarani, com o objetivo de carregar experimentos de astrobiologia até as condições extremas da estratosfera terrestre.

\subsubsection{Garatéa I}

A primeira missão Garatéa voou em um balão estratosférico com objetivo de participar do Global Space Balloon Challenge (GSBC) de 2016. O GSBC é um projeto internacional que encoraja pessoas do mundo inteiro a construir e lançar seus próprios balões de alta-altitude, incentivando, assim, o desenvolvimento do conhecimento em ciência e tecnologia, além da organização e trabalho em grupo. (90)

O balão foi lançado no dia 14 de maio de 2016 da cidade de São Carlos (SP). A sonda expôs nossas amostras às condições da estratosfera por cerca de 2 horas, coletando informações ambientais durante o voo. Depois a sonda foi recuperada e as amostras foram analisadas em laboratório. A Figura 30.a mostra o time preparando o balão para o voo, e a Figura 30.b mostra a sonda Garatéa I carregada pelo balão, a $32 \mathrm{~km}$ de altitude acima do nível do mar.

A sonda expôs às condições da estratosfera microrganismos extremofílicos e biomoléculas. O Laboratório Quimiosfera do Instituto de Química da USP de São Paulo, liderado pelo Prof. Dr. Fabio Rodrigues, também integrante do NAP/Astrobio, foi responsável pelo experimento com os organismos extremofílicos. E o experimento com biomoléculas foi desenvolvido dentro dos objetivos do presente trabalho de mestrado.

Amostras de pigmentos biológicos, clorofila a (puro), $\beta$-caroteno (puro) e pigmentos extraídos do microrganismo Deinococcus radiodurans, foram depositados em triplicata por evaporação do solvente em substratos de silício e alumínio (descrito na seção 3.2.1), e são mostradas na Figura 31. Duas das replicatas foram enviadas no balão para serem irradiadas e uma ficou em laboratório no escuro para servir como controle. Análises das amostras foram feitas por espectroscopia Raman. 

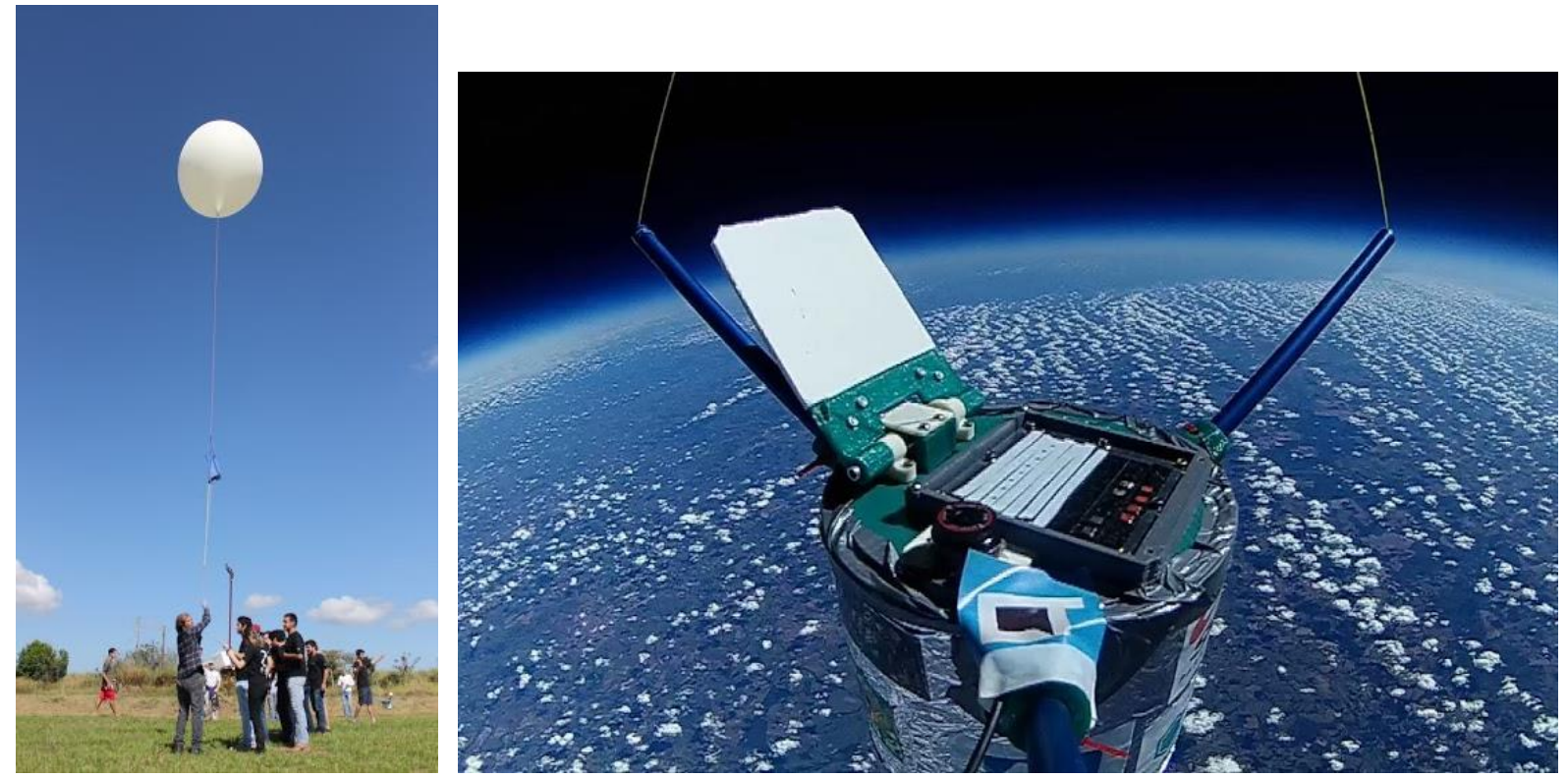

Figura 30 - a- Preparo do balão estratosférico para voo carregando a sonda Garatéa I (São Carlos-SP). b- Sonda Garatéa, a $32 \mathrm{~km}$ de altitude, expondo as amostras às condições estratosféricas. Fonte: Cedida pelo grupo Zenith

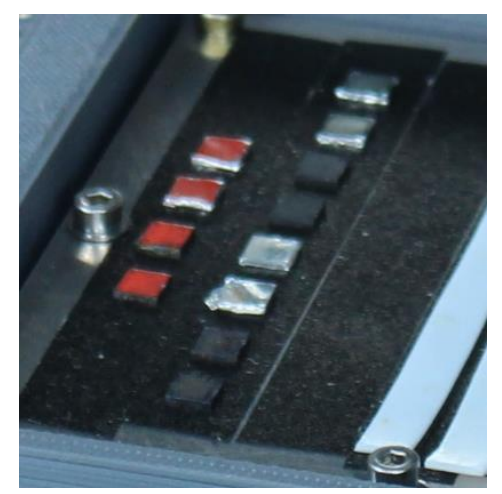

Figura 31 - Porta amostras utilizado na Garatéa-I aberto com as amostras depositadas em alumínio (quadrados mais claros), e silício (quadrados mais escuros).

Fonte: Obtida pela autora

\subsubsection{Garatéa II}

Após o sucesso da primeira missão Garatéa, uma segunda sonda foi projetada e construída pelo grupo Zenith, nomeada Garatéa II. O lançamento da sonda, a bordo de um balão estratosférico, ocorreu no dia 19 de dezembro de 2016 da cidade de São Carlos (SP). Ela viajou através da estratosfera terrestre durante aproximadamente uma hora, atingindo uma altitude máxima de 25,5 km acima do nível do mar, e foi recuperada após o voo para análise dos experimentos. A Figura 32 mostra a sonda Garatéa II em sua máxima altitude, expondo as amostras às condições estratosféricas. 


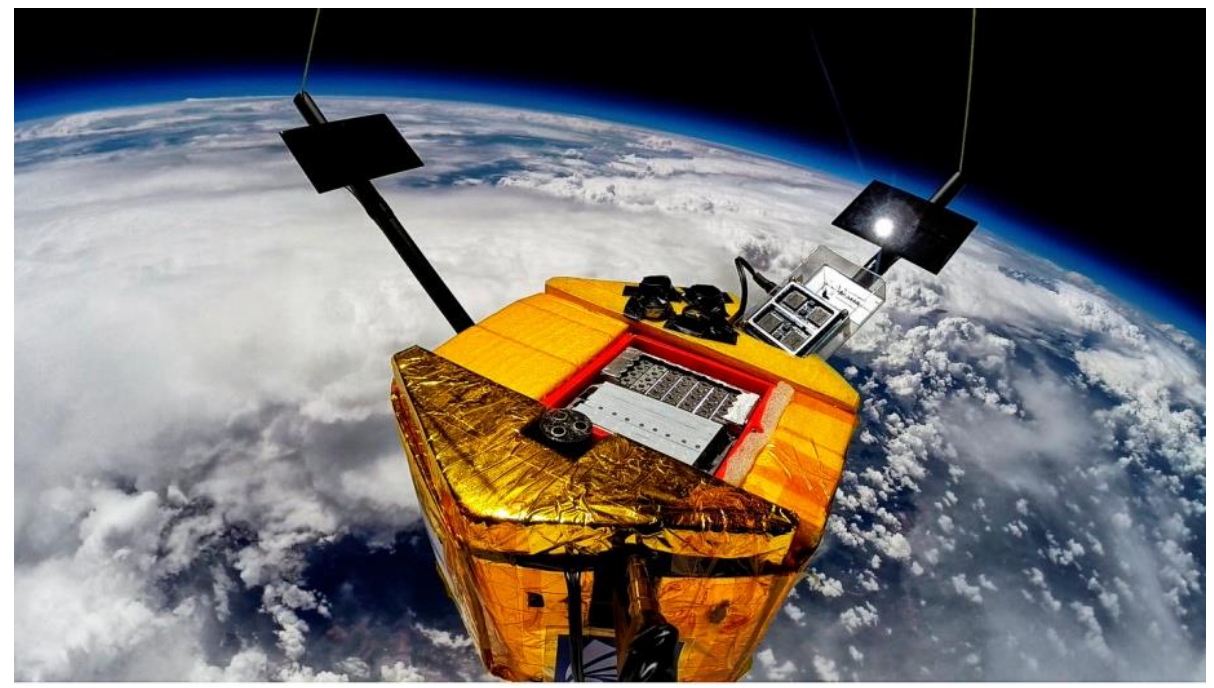

Figura 32 - Sonda da missão Garatéa-II em sua máxima altitude, expondo as amostras às condições estratosféricas.

Fonte: Cedida pelo grupo Zenith

Dados ambientais foram coletados durante o voo com o objetivo de confirmar a similaridade entre as condições ambientais da estratosfera terrestre e da superfície de Marte. Um problema instrumental impediu a aquisição das medidas de fluxo UV durante o voo do balão. Para comparação, a Tabela 6 mostra os dados coletados neste experimento, além de dados coletados em outros voos, e também dados calculados de modelos teóricos, encontrados na literatura.

A sonda expôs às condições da estratosfera microrganismos extremofílicos e diversas biomoléculas de diferentes classes, detalhadas na Tabela 7. Novamente, o experimento com biomoléculas foi desenvolvido dentro dos objetivos do presente trabalho de mestrado, e o Laboratório Quimiosfera foi responsável pelo experimento com os organismos extremofílicos. Porém, devido à chuva no momento da recuperação da sonda, e a falta de tampa protetora, o experimento com microrganismos foi perdido.

Amostras do aminoácido DL-cisteína foram expostas tanto na forma pura quanto misturadas com cinco diferentes substratos inorgânicos, relevantes à superfície marciana. E à todas as amostras foi misturado pó de diamante para ser possível uma análise quantitativa utilizando espectroscopia Raman. 
Tabela 6 - Comparação entre as condições ambientais da estratosfera terrestre, entre 12 e 25 km acima do nível do mar, e da superfície de Marte.

\begin{tabular}{|c|c|c|c|}
\hline \multirow[b]{2}{*}{ Parâmetro } & \multirow{2}{*}{$\begin{array}{c}\text { Superfície de Marte } \\
\text { Medidos (Curiosity) a }^{a}\end{array}$} & \multicolumn{2}{|c|}{ Estratosfera da Terra $(12-25 \mathrm{~km})$} \\
\hline & & $\begin{array}{c}\text { Medidos } \\
\text { (Garatéa II) }^{\text {b }}\end{array}$ & $\begin{array}{c}\text { Medidos } \\
\text { (outros voos) }\end{array}$ \\
\hline Pressão (mbar) & $7,3-9,2$ & $193-11$ & $50^{\mathrm{c}}$ \\
\hline Temperatura $(\mathrm{K})$ & 240 (superfície) / 233 (ar) & $253-279$ & $203-233^{d}$ \\
\hline Umidade relativa $(\%)$ & $\sim 0$ & $1-2.6$ & $\sim 1^{\mathrm{d}}$ \\
\hline Radiação & Calculados $^{\mathrm{e}}$ & \multicolumn{2}{|c|}{ Calculados ${ }^{f}$} \\
\hline $\operatorname{UVA}\left(\mathrm{W} / \mathrm{m}^{2}\right) 315-400 \mathrm{~nm}$ & 38,39 & \multicolumn{2}{|c|}{82,35} \\
\hline $\mathrm{UVB}\left(\mathrm{W} / \mathrm{m}^{2}\right) 280-315 \mathrm{~nm}$ & 8,38 & \multicolumn{2}{|c|}{4,16} \\
\hline $\mathrm{UVC}\left(\mathrm{W} / \mathrm{m}^{2}\right) 200-280 \mathrm{~nm}$ & 3,18 & \multicolumn{2}{|c|}{0,0055} \\
\hline UV total $\left(\mathrm{W} / \mathrm{m}^{2}\right)$ & 50,6 & \multicolumn{2}{|c|}{86,6} \\
\hline
\end{tabular}

a Valores medidos pelo instrumento "Rover Environmental Monitoring Station" do "Mars Science Laboratory" a bordo do rover Curiosity (NASA). (41)

b Valores mínimo e máximo medidos durante voo da Garatéa II, entre 12 e 25 km de altitude.

${ }^{c}$ Valor medido durante voo a $20 \mathrm{~km}$ de altitude. (91)

d Valores mínimo e máximo medidos durante voo do experimento E-MIST entre 12 e $25 \mathrm{~km}$ de altitude. (42)

e Valores calculados de modelo teórico (estimado como $43 \%$ da constante solar na Terra). (87)

${ }^{\mathrm{f}}$ Valores calculados de modelo teórico a $20 \mathrm{~km}$ de altitude. (92)

Fonte: Adaptada pela autora

Tabela 7 - Misturas de amostras utilizadas no experimento de simulação em ambiente estratosférico.

\begin{tabular}{c|c|c}
\hline Amostra & $\begin{array}{c}\text { Concentração de Substrato } \\
(\% \text { em massa) }\end{array}$ & $\begin{array}{c}\text { Concentração de Pó de } \\
\text { Diamante (\% em massa) }\end{array}$ \\
\hline DL-cisteína & - & $3 \%$ \\
\hline DL-cisteína & $70 \%$ Caulinita $\left(\mathrm{KG}_{\mathrm{a}-2}\right)$ & $3 \%$ \\
\hline DL-cisteína & $70 \%$ Montmorilonita $\left(\mathrm{SY}_{\mathrm{n}-1}\right)$ & $3 \%$ \\
\hline DL-cisteína & $70 \%$ JSC-Mars $1 \mathrm{~A}$ & $3 \%$ \\
\hline DL-cisteína & $70 \%$ Goetita & $3 \%$ \\
\hline DL-cisteína & $70 \%$ Sulfato de Magnésio \\
hexahidratado & $3 \%$ \\
\hline L-cistina & - & $50 \%$ \\
\hline Fulereno C60 & - & $50 \%$ \\
\hline$\beta$-caroteno (puro) & - & $3 \%$ \\
\hline Guanina & - & $10 \%$ \\
\hline Deinococcus radiodurans & - & $3 \%$ \\
\hline Hemina & - & $5 \%$ \\
\hline ATP & - & $3 \%$ \\
\hline Ácido fumárico & - & 30 \\
\hline
\end{tabular}

Fonte: Elaborada pela autora 
Para o experimento das biomoléculas, um novo porta-amostras foi construído por um aluno de iniciação científica integrante do grupo de pesquisa, Rodrigo Abans, para que as amostras fossem expostas hidratadas. A Figura 33 mostra o porta-amostras de alumínio, com poços onde as amostras foram adicionadas em pó. Então, foram adicionados a cada poço $3 \mu \mathrm{L}$ de água deionizada (18.2 M $\Omega . \mathrm{cm})$, uma camada de filme polimérico Ultralene ${ }^{\circledR}$, e o-rings de teflon, tampas de alumínio e parafusos para a vedação completa.

Foram preparados três destes porta-amostras com 14 amostras cada, em duplicata. Um deles voou com o balão e foi ‘exposto à radiação' (E). Outro também voou com o balão, mas foi mantido coberto e 'não foi exposto à radiação' $(\mathrm{N})$, para comparar os efeitos da radiação e das outras condições da estratosfera (temperatura, pressão e umidade) separadamente. E outro porta-amostras foi mantido no escuro no laboratório, para servir de 'controle em Terra' (C).

Todas as amostras foram analisadas por espectroscopia Raman e, por isso, foram misturadas com 3 a 50\% de pó de diamante, para ser possível a quantificação.
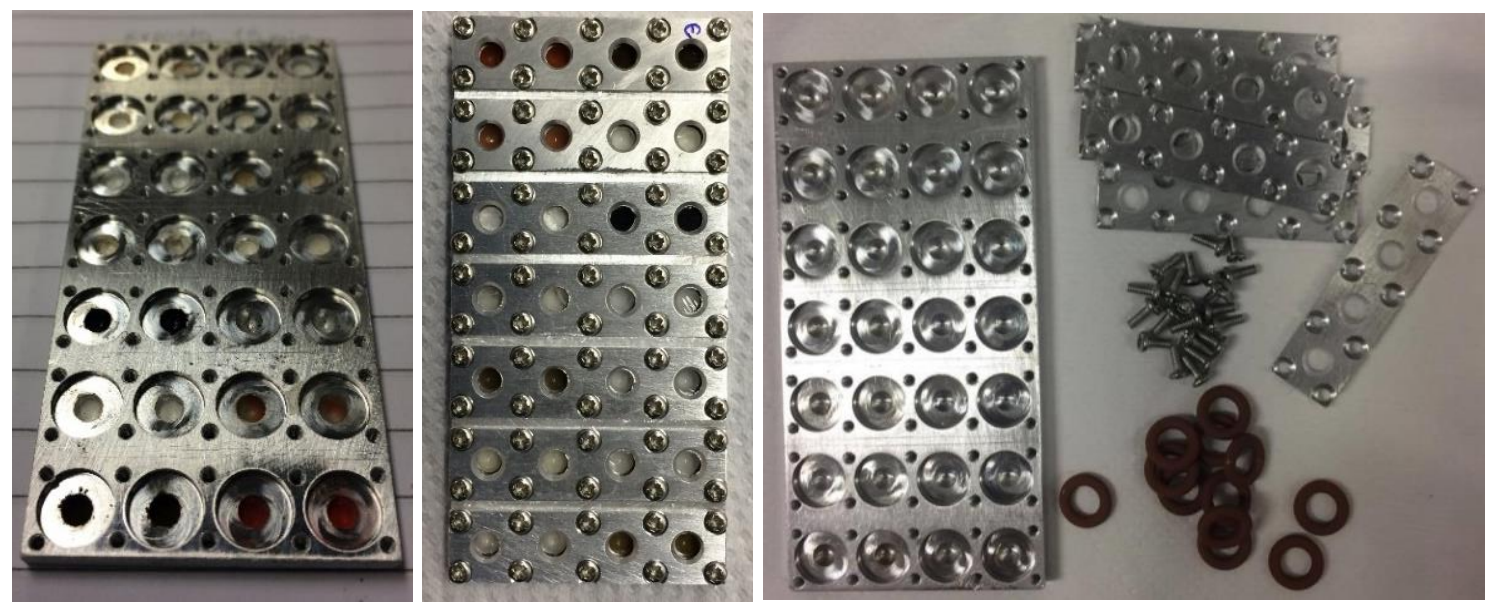

Figura 33 - Porta amostras utilizado na Garatéa-II aberto com as amostras em pó (esquerda), fechado e vedado (meio), e detalhe das peças separadas (direita).

Fonte: Obtida pela autora 


\section{RESULTADOS E DISCUSSÃO}

\subsection{Detectabilidade espectroscópica das amostras de interesse}

A detectabilidade de todas as amostras utilizadas foi estudada e testada com os métodos espectroscópicos disponíveis e detalhados na seção 1.7. Como foi dado um maior foco para os pigmentos biológicos, seus espectros obtidos com cada uma das técnicas foram mais profundamente analisados.

\subsubsection{Espectros no infravermelho (FTIR)}

A Figura 34 mostra os espectros obtidos no infravermelho (equipamento FTIR disponível no LNLS) das amostras de $\beta$-caroteno puro e natural (da cenoura) em pó. Há alguns picos com diferentes intensidades e pequenos deslocamentos entre si, mas ambos espectros mostram boa concordância com espectros encontrados na literatura. (16)

A Figura 35 mostra os espectros obtidos no infravermelho das amostras de Spirulina (Arthospira platenis) em pó, e da clorofila a extraída da Spirulina. Para a extração, foi feita uma solução supersaturada de Spirulina em etanol P.A., a qual foi deixada em ultrassom por 20 minutos e depois centrifugada por 10 minutos para eliminar o precipitado, deixando uma solução com uma concentração maior de clorofila a. A amostra em pó de clorofila foi obtida após a evaporação completa do solvente. Também há alguns picos com diferentes intensidades e pequenos deslocamentos entre si, mas ambos espectros mostram boa concordância com espectros encontrados na literatura. (17)

As Tabelas 8 e 9 mostram as ligações que deram origem a cada pico nos espectros FTIR do $\beta$-caroteno e clorofila, respectivamente, inferidas a partir de tabelas de referência disponibilizadas por Scheinmann (93). Quase todos os picos são encontrados em ambas as amostras (pura e natural), com pequenos deslocamentos. 


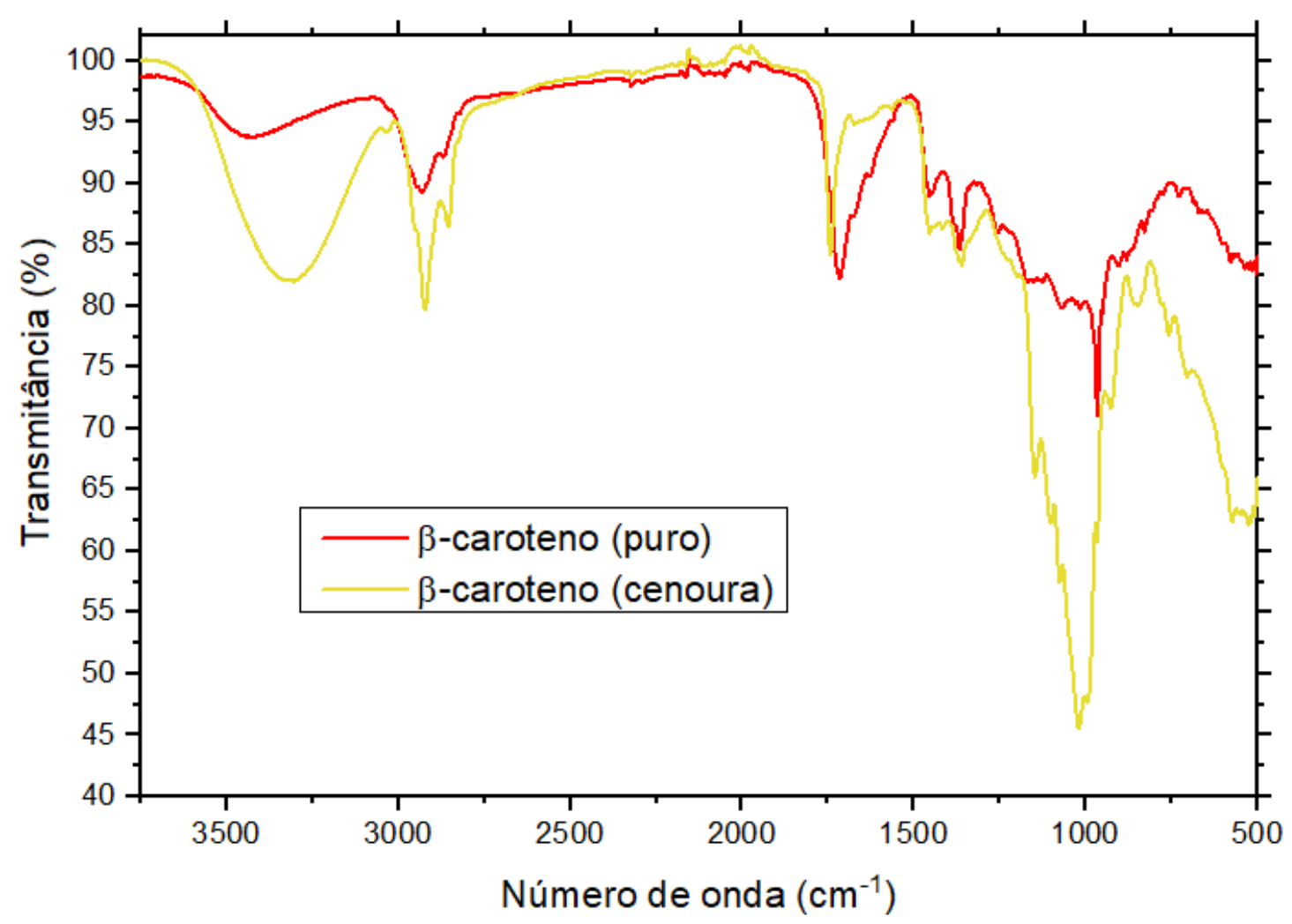

Figura 34 - Espectros FTIR (modo ATR) obtidos das amostras de $\beta$-caroteno puro e natural (da cenoura) em pó. Fonte: Elaborada pela autora

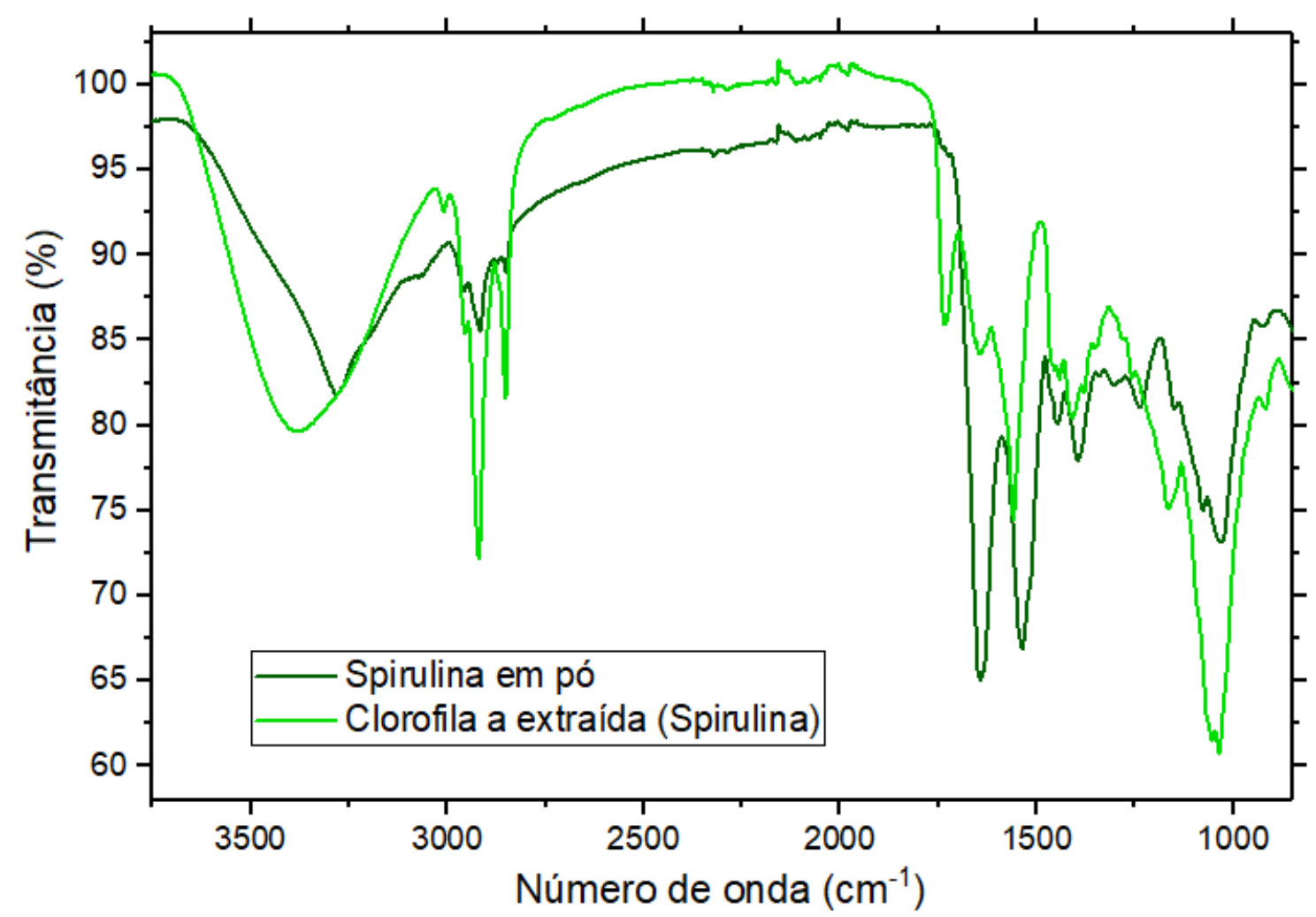

Figura 35 - Espectros FTIR (modo ATR) obtidos da amostra de clorofila a natural (Spirulina) e seu extrato em etanol.

Fonte: Elaborada pela autora 
Tabela 8 - Identificação dos picos do espectro de infravermelho do $\beta$-caroteno.

\begin{tabular}{c|c|c|c}
\hline \multicolumn{2}{c|}{ Número de onda $\left(\mathbf{c m}^{-1}\right)$} & \multirow{2}{*}{ Intensidade } & \multirow{2}{*}{ Identificação } \\
\cline { 1 - 2 } pura & natural & fraco & $\delta(\mathrm{C}=\mathrm{C})$ monossubstituído \\
\hline 905 & 925 & forte & $\delta(\mathrm{C}=\mathrm{C})$ dissubstituído \\
\hline 965 & 965 & forte & $\delta(\mathrm{C}=\mathrm{C})$ monossubstituído \\
\hline- & 992 & fraco / forte & $\delta(\mathrm{C}-\mathrm{O})$ \\
\hline 1015 & 1020 & fraco / forte & $\delta(\mathrm{C}-\mathrm{O})$ \\
\hline 1070 & 1075 & médio & $v(\mathrm{C}-\mathrm{O})$ \\
\hline- & 1100 & médio & $v(\mathrm{C}-\mathrm{O})$ \\
\hline- & 1147 & fraco & $\delta_{\text {sim }}(\mathrm{C}-\mathrm{H})$ de metila $\left(-\mathrm{CH}_{3}\right)$ \\
\hline 1258 & - & fraco & $\delta_{\text {assim }}(\mathrm{C}-\mathrm{H})$ de metila $\left(-\mathrm{CH}_{3}\right)$ \\
\hline 1367 & 1367 & médio & $v(\mathrm{C}=\mathrm{C})$ conjugadas em polienos \\
\hline 1455 & 1455 & fraco & $v(\mathrm{C}=\mathrm{C})$ conjugadas em polienos \\
\hline 1562 & 1562 & médio & $v(\mathrm{C}=\mathrm{C})$ dissubstituído \\
\hline 1629 & - & médio & $v(\mathrm{C}=\mathrm{O})$ aldeídos? \\
\hline 1673 & 1673 & médio & $v_{\text {sim }}(\mathrm{C}-\mathrm{H})$ de metileno $\left(-\mathrm{CH}_{2}-\right)$ \\
\hline 1715,1722 & 1742 & médio & $v_{\text {sim }}(\mathrm{C}-\mathrm{H})$ de metila $\left(-\mathrm{CH}_{3}\right)$ \\
\hline 2852 & 2851 & muito fraco & $v_{\text {assim }}(\mathrm{C}-\mathrm{H})$ de metileno $\left(-\mathrm{CH}_{2}-\right)$ \\
\hline 2872 & 2872 & forte / médio & $v_{\text {assim }}(\mathrm{C}-\mathrm{H})$ de metila $\left(-\mathrm{CH}_{3}\right)$ \\
\hline 2921 & 2917 & fraco & $v(=\mathrm{C}-\mathrm{H})$ ou $v(\mathrm{C}-\mathrm{H})$ alifáticos \\
\hline 2955 & 2957 & fraco & $v(\mathrm{O}-\mathrm{H})-$ associada por lig. $\mathrm{H}$ \\
\hline 3010 & - & médio largo &
\end{tabular}

Tabela 9 - Identificação dos picos do espectro de infravermelho da clorofila a.

\begin{tabular}{c|c|c|c}
\multicolumn{2}{c|}{ Número de onda $\left(\mathbf{c m}^{-1}\right)$} & \multirow{2}{*}{ Intensidade } & \multirow{2}{*}{ Identificação } \\
\cline { 1 - 2 } pura & natural & fraco & $\delta(\mathrm{C}=\mathrm{C})$ monossubstituído \\
\hline 918 & 918 & forte & $\delta(\mathrm{C}-\mathrm{O})$ éster \\
\hline 1036 & 1030 & forte $($ ombro $) /$ médio & $v(\mathrm{C}-\mathrm{O})$ éster \\
\hline 1055 & 1078 & médio / fraco & $v(\mathrm{C}-\mathrm{O})$ éster \\
\hline 1167 & 1151 & muito fraco / fraco & $\delta_{\text {sim }}(\mathrm{C}-\mathrm{H})$ de metila $\left(-\mathrm{CH}_{3}\right)$ \\
\hline 1258 & 1236 & médio & $\delta_{\text {assim }}(\mathrm{C}-\mathrm{H})$ de metila $\left(-\mathrm{CH}_{3}\right)$ \\
\hline 1410 & 1395 & médio & $v(\mathrm{C}=\mathrm{C})$ aromáticos \\
\hline 1450 & 1450 & médio & $v(\mathrm{C}=\mathrm{N})$ ou $v(\mathrm{C}=\mathrm{C})$ vinil terminal \\
\hline 1560 & 1538 & fraco / forte & $v(\mathrm{C}=\mathrm{O})$ éster \\
\hline 1645 & 1645 & médio & $v_{\text {sim }}(\mathrm{C}-\mathrm{H})$ de metileno $\left(-\mathrm{CH}_{2}-\right)$ \\
\hline 1734 & - & médio & $v_{\text {sim }}(\mathrm{C}-\mathrm{H})$ de metila $\left(-\mathrm{CH}_{3}\right)$ \\
\hline 2852 & 2851 & muito fraco & $v_{\text {assim }}(\mathrm{C}-\mathrm{H})$ de metileno $\left(-\mathrm{CH}_{2}-\right)$ \\
\hline 2872 & 2872 & forte / médio & $v_{\text {assim }}(\mathrm{C}-\mathrm{H})$ de metila $\left(-\mathrm{CH}_{3}\right)$ \\
\hline 2921 & 2917 & fraco & $v(\mathrm{C}=\mathrm{C}-\mathrm{H})$ ou $v(\mathrm{C}-\mathrm{H})$ alifáticos \\
\hline 2955 & 2957 & fraco & $v(\mathrm{O}-\mathrm{H})-$ associada por lig. $\mathrm{H}$ \\
\hline 3010 & - & médio largo &
\end{tabular}


Há regiões distintas identificáveis nos espectros infravermelho. Entre 3.600 e $2.700 \mathrm{~cm}^{-1}$ as absorções são associadas às vibrações de deformação axial (ou stretching), denotadas por "v", nos átomos de hidrogênio ligados a carbono, oxigênio e nitrogênio ( $\mathrm{C}-\mathrm{H}, \mathrm{O}-\mathrm{H}$ e N-H). No caso, as amostras apresentam somente ligações $\mathrm{C}-\mathrm{H}$, e as vibrações associadas às ligações $\mathrm{O}-\mathrm{H}$ devem ser devido a umidade presente na amostra. Entre 1900 e $1500 \mathrm{~cm}^{-1}$ as absorções são associadas às vibrações de deformação axial de duplas ligações $(\mathrm{C}=\mathrm{C})$, de grupos carbonila $(\mathrm{C}=\mathrm{O})$ e de $\mathrm{C}=\mathrm{N}$, as últimas estando presente somente na clorofila. E entre 1.500 e $600 \mathrm{~cm}^{-1}$ as absorções são associadas a diversos tipos de vibração: deformações angulares (ou bending), denotado por " $\delta$ ", de ligações $\mathrm{C}-\mathrm{H}$ e $\mathrm{C}=\mathrm{C}$; e deformações axiais e angulares de ligações $\mathrm{C}-\mathrm{C}$, $\mathrm{C}-\mathrm{N}, \mathrm{C}-\mathrm{O}$, sendo as duas últimas somente para a clorofila.

A presença do grupo carbonila na região de aldeídos nos espectros do $\beta$-caroteno podem estar associadas a uma oxidação e quebra das moléculas formando o aldeído da vitamina A (retinal), assim como as ligações C-O de álcoois podem estar associadas à oxidação até a própria vitamina A (retinol). (13) As estruturas do retinol e retinal são mostradas na Figura 36.

E podemos observar que o grupo carbonila de éster está presente somente na amostra extraída da Spirulina, podendo ser explicado por uma possível complexação da clorofila a com alguma proteína da cianobactéria que impede a detecção do éster.
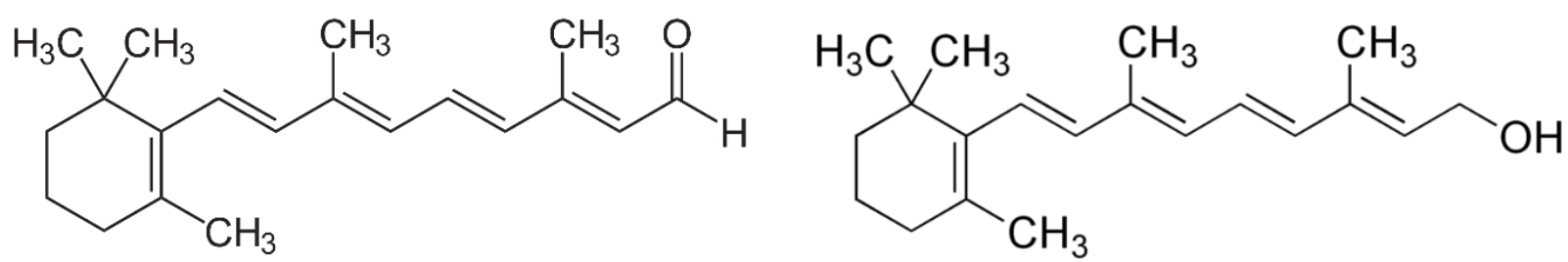

Figura 36 - Estruturas químicas dos derivados do $\beta$-caroteno, retinal (esquerda) e retinol (direita). Fonte: ALL-TRANS-RETINAL. (94); RETINOL. (95)

\subsubsection{Espectros Raman}

A Figura 37 mostra os espectros obtidos por espalhamento Raman (equipamento microRaman disponível no LNLS) das amostras de $\beta$-caroteno puro e natural (da cenoura) em pó. Ambas apresentam os mesmos 3 picos característicos de carotenoides, em concordância com espectros da literatura, sem variações nos picos da amostra pura para a natural. (18) A Tabela 10 mostra as ligações cujas vibrações dão origem aos picos Raman.

A amostra de clorofila a apresenta somente uma alta fluorescência ao ser analisada por espectroscopia Raman com laser de $785 \mathrm{~nm}$, sem ser possível a identificação de nenhum pico e, portanto, não foi analisada por esta técnica durante os experimentos. 


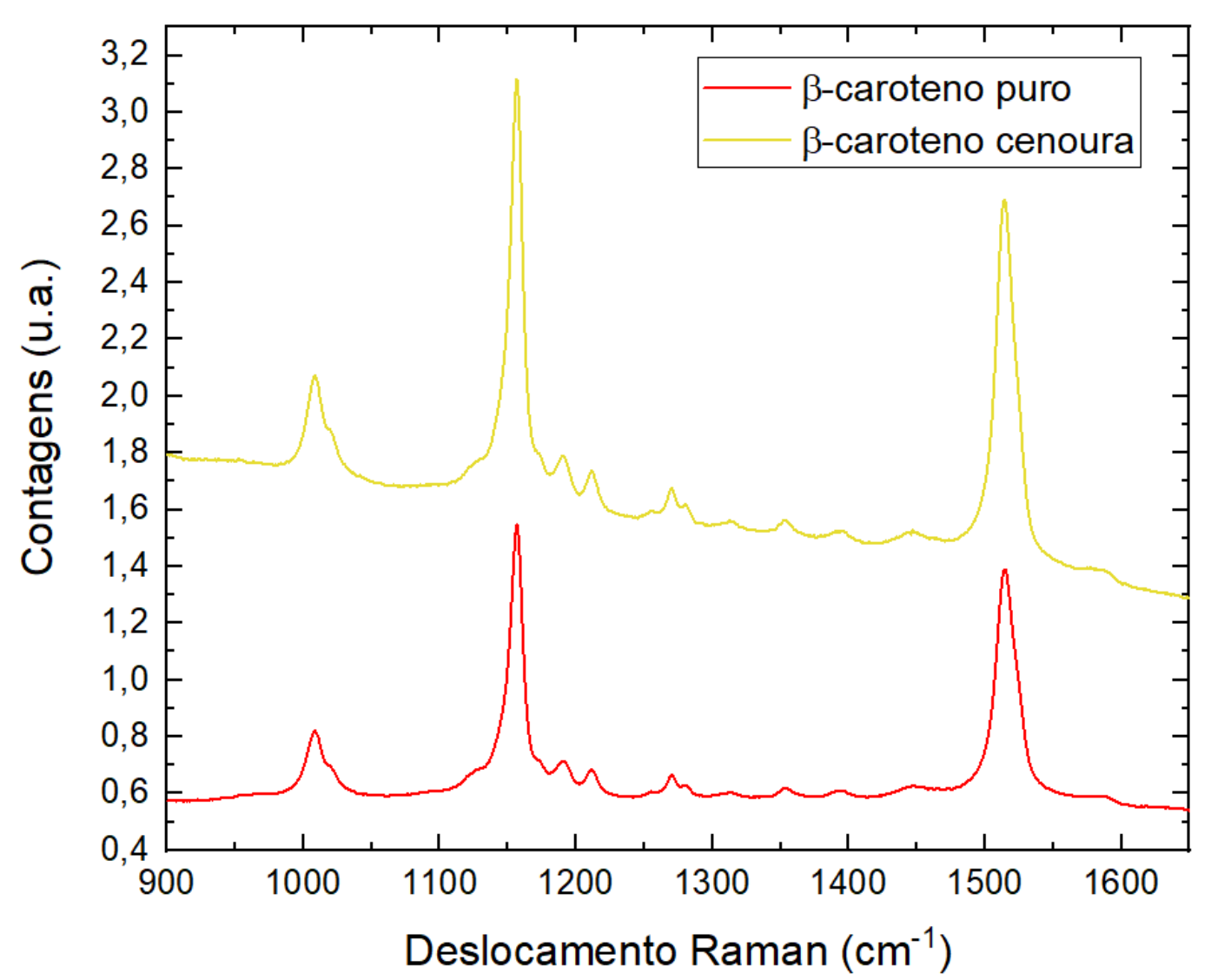

Figura 37 - Espectro Raman obtidos das amostras de $\beta$-caroteno puro e natural (da cenoura) em pó, com laser de $785 \mathrm{~nm}$.

Fonte: Elaborada pela autora

Tabela 10 - Identificação dos picos do espectro Raman do $\beta$-caroteno.

\begin{tabular}{c|c}
\hline Raman shift $\left(\mathbf{c m}^{-1}\right)$ & Identificação \\
\hline 1008 & $\delta(\mathrm{C}=\mathrm{CH})+\delta(\mathrm{C}-\mathrm{H})$ \\
\hline 1157 & $v(\mathrm{C}-\mathrm{C})$ \\
\hline 1515 & $v(\mathrm{C}=\mathrm{C})$ \\
\hline
\end{tabular}

Fonte: Adaptada de MARSHALL; OLCOTT-MARSHALL (96)

\subsubsection{Espectros no UV-Vis}

As Figura 38 mostra os espectros obtidos no UV-Vis das amostras de $\beta$-caroteno puro e natural (da cenoura) em pó. Foram utilizados dois equipamentos de bancada: um com setup para transmissão, disponível no LNLS, e outro com setup de reflectância, disponível no Laboratório de Espectroscopia Molecular do IQ da USP de São Paulo.

Os dados de reflectância são transformados em absorbância utilizando a equação de Kubelka-Munk (equação 35), e os dados de transmitância são transformados em absorbância utilizando a equação 36 , onde a transmitância é $T=\left(I_{t} / I_{i}\right) \times 100$. 


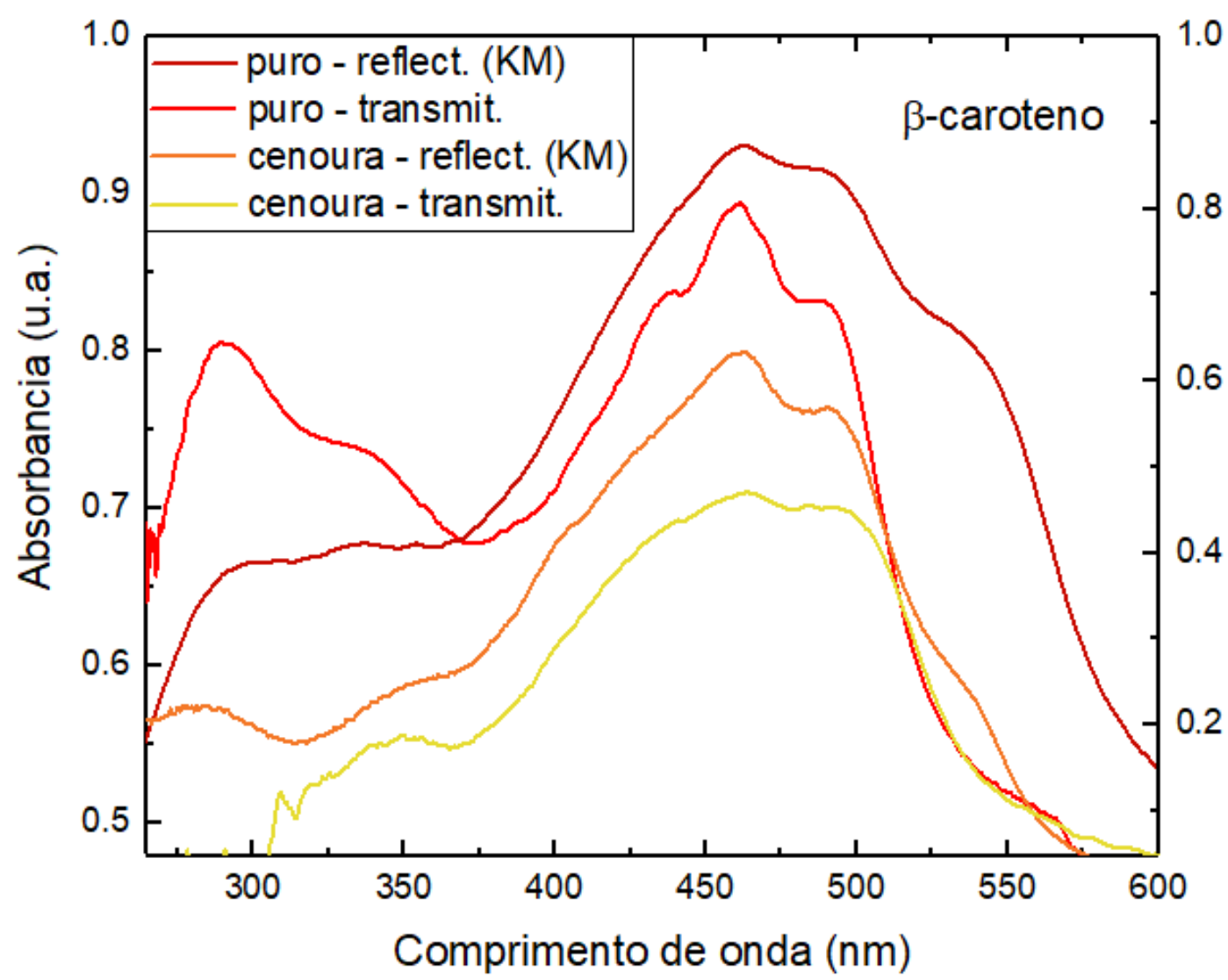

Figura 38 - Espectros de absorção no UV-Vis obtidos das amostras de $\beta$-caroteno puro e natural (da cenoura), por transmitância e por reflectância. Eixos y normalizados (unidades arbitrárias).

Fonte: Elaborada pela autora

Pode-se observar que o perfil dos espectros do $\beta$-caroteno apresenta pequenas variações de acordo com a técnica sendo utilizada, o preparo e o tipo de amostra. A Tabela 11 mostra as posições das bandas no $\beta$-caroteno puro e no natural. Algumas bandas que aparecem na amostra pura não aparecem na amostra natural. Entretanto, as principais bandas características desse carotenoide, em $\sim 460$ e em $\sim 90$ nm, são visíveis e consistentes com os espectros da literatura e, portanto, foram utilizadas nas análises dos experimentos. (13)

Tabela 11 - Posições dos picos dos espectros de absorbância no UV-Vis das amostras de $\beta$-caroteno.

\begin{tabular}{c|c}
\hline \multicolumn{2}{c}{ Comprimento de onda (nm) } \\
\hline $\boldsymbol{\beta}$-caroteno puro & $\boldsymbol{\beta}$-caroteno (cenoura) \\
\hline 290 & 284 \\
\hline 437 & 437 \\
\hline 461 & 462 \\
\hline 489 & 492 \\
\hline 536 & 537 \\
\hline
\end{tabular}

Fonte: Elaborada pela autora 
A Figura 39 mostra os espectros obtidos no UV-Vis das amostras de clorofila a natural (Spirulina) e extraída da Spirulina em etanol, ambos por transmissão.

Os espectros apresentam uma maior variação no perfil e nas posições dos picos, mostrados na Tabela 12. Isso pode ser explicado pelo estado da clorofila a na amostra natural, possivelmente complexada em proteínas da cianobactéria Spirulina. Tais variações são consistentes com os espectros da literatura. (19) E as bandas em 491 nm são provavelmente devido à presença de carotenoides na amostra de Spirulina, sendo confirmada com a sua diminuição na amostra extraída em etanol.

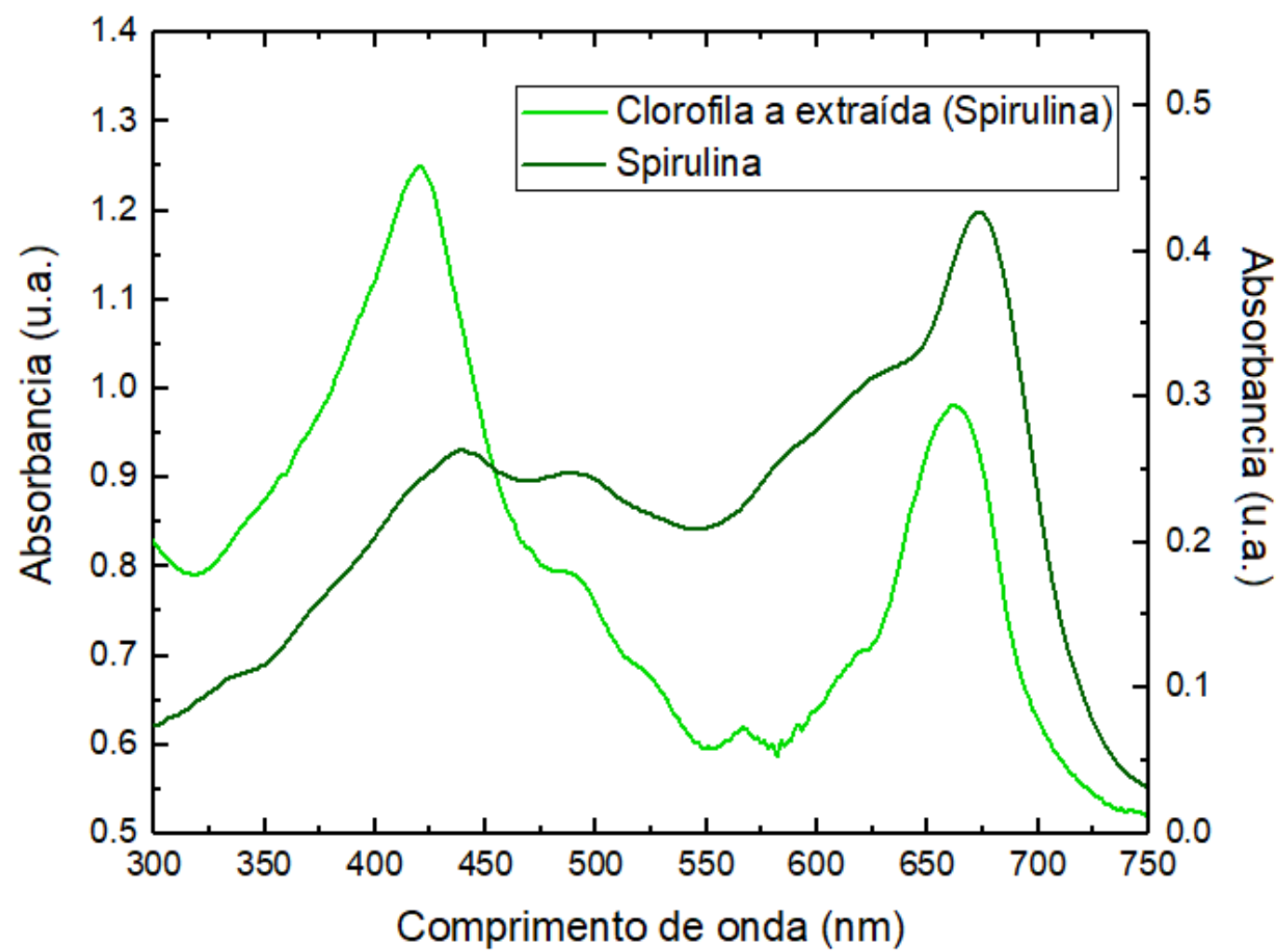

Figura 39 - Espectros de absorção no UV-Vis obtidos por transmitância das amostras de clorofila a natural (Spirulina) e seu extrato em etanol.

Fonte: Elaborada pela autora

Tabela 12 - Posições dos picos dos espectros de absorbância no UV-Vis das amostras de Spirulina pura e seu extrato em etanol.

\begin{tabular}{c|c}
\hline \multicolumn{2}{c}{ Comprimento de onda (nm) } \\
\hline Spirulina pura & Clorofila a extraída \\
\hline 439 & 419 \\
\hline 672 & 661 \\
\hline
\end{tabular}

Fonte: Elaborada pela autora 
A base da coloração dos pigmentos são seus sistemas conjugados de duplas ligações, com elétrons- $\pi$ deslocalizados altamente energéticos (ver estruturas na Figura 1). Os carotenoides absorvem luz na região azul do espectro e consequentemente emitem na região do laranja/vermelho. E as clorofilas absorvem nas regiões do azul e do vermelho, emitindo na região do verde. As absorções das ligações duplas $\mathrm{C}=\mathrm{C}$ resultam na excitação de um elétron $\pi$ para um orbital antiligante $\pi^{*}$. A atividade cromófora dessa ligação é derivada dessas transições eletrônicas $\pi \rightarrow \pi^{*}$ (onde lê-se " $\pi$ a $\pi$-estrela") entre orbitais HOMOs (orbital molecular ocupado mais energético) e LUMOs (orbital molecular desocupado menos energético), cujas separações em energia correspondem aos comprimentos de onda absorvidos. Essa energia é por volta de 7 eV para uma ligação dupla não conjugada, o que corresponde a um comprimento de onda de $180 \mathrm{~nm}$. Quando a ligação faz parte de uma cadeia de duplas conjugadas, a diferença de energia entre os orbitais moleculares diminui e a transição muda para comprimentos de onda maiores, podendo chegar à faixa do visível, se a cadeia for longa o suficiente.

No caso especifico da clorofila a, o espectro eletrônico com duas bandas vem da absorção típica de porfirinas: uma transição do estado fundamental ao segundo estado excitado $\left(\mathrm{S}_{0} \rightarrow\right.$ $\mathrm{S}_{2}$ ) na região de 380 a $500 \mathrm{~nm}$ (chamada de banda "Soret" ou "B"), e outra ao primeiro estado excitado $\left(\mathrm{S}_{0} \rightarrow \mathrm{S}_{1}\right)$ na região de 500 a $750 \mathrm{~nm}$ (banda “Q”). (97)

\subsection{EXPERIMENTOS EM LABORATÓRIO}

\subsubsection{Irradiação UVC}

Os filmes dos pigmentos biológicos foram irradiados com luz UVC durante um total de 4 horas, retirando as amostras após 15, 30, 45, 60, 90, 120, 180 e 240 minutos, para sua caracterização espectroscópica. A Figura 40 mostra fotos dos filmes em cada intervalo durante as irradiações, onde os filmes de coloração laranja são de $\beta$-caroteno, e os de coloração verde são de Clorofila a. 


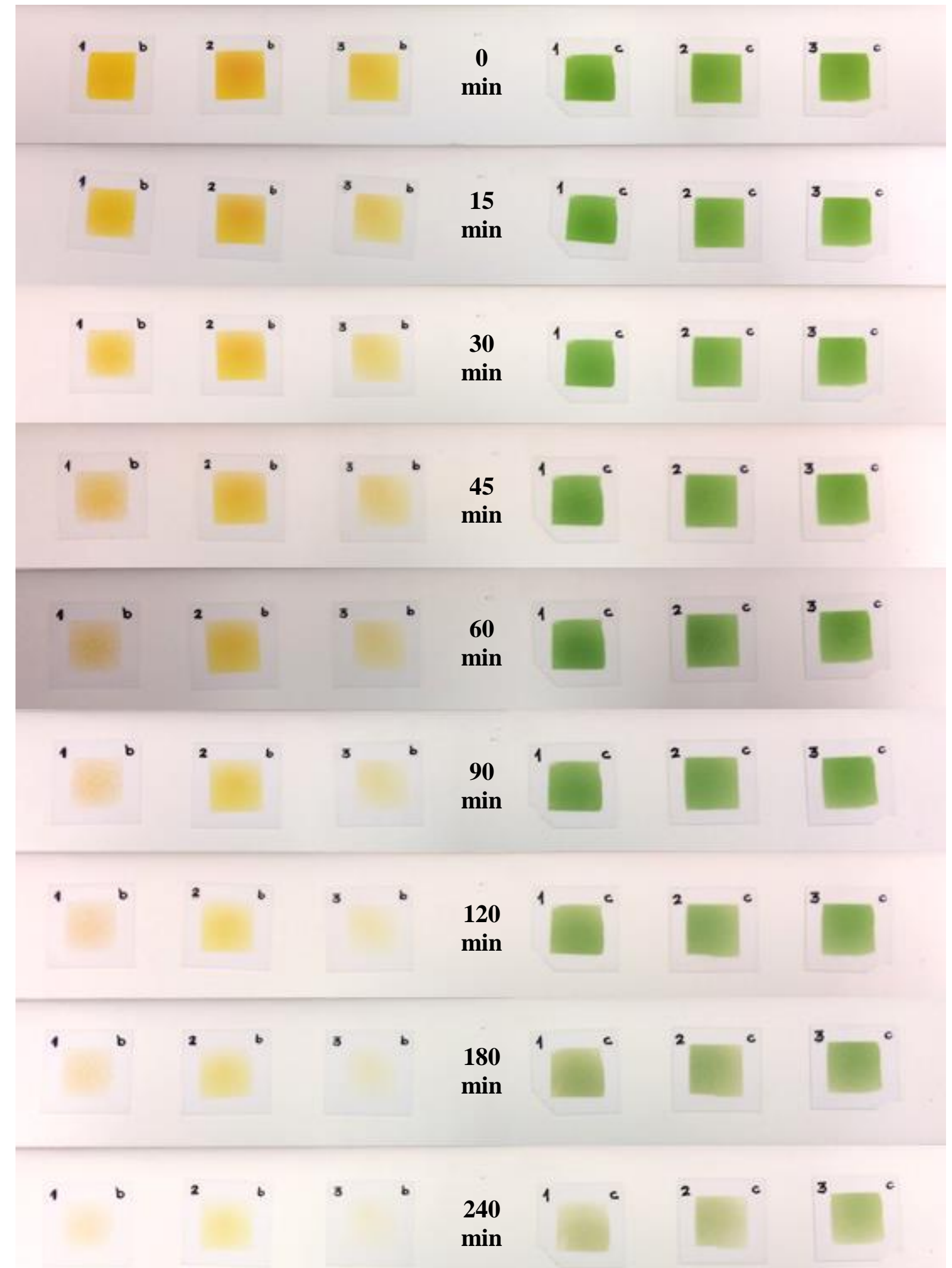

Figura 40 - Fotos dos filmes de pigmentos biológicos (laranja: $\beta$-caroteno e verde: Clorofila a) obtidas em cada intervalo de tempo durante as irradiações com luz UVC.

Fonte: Obtida pela autora 
4.2.1.1 Cálculo das espessuras dos filmes

As espessuras, $e(\mathrm{em} \mu \mathrm{m})$, dos filmes podem ser calculadas a partir da equação:

$$
e=\frac{m}{d . A} \times 10^{4}
$$

Onde $m$ é a massa do filme $(\mathrm{g}), d$ é a densidade da molécula $\left(\mathrm{g} \cdot \mathrm{cm}^{-3}\right)$, e $A$ é a área do filme $\left(\mathrm{cm}^{2}\right)$. As espessuras calculadas para os 3 filmes de cada amostra estão na Tabela 13.

Tabela 13 - Espessuras dos filmes de $\beta$-caroteno e clorofila a (Spirulina).

\begin{tabular}{c|c|c}
\hline Amostra & Filme & Espessura $(\boldsymbol{\mu m})$ \\
\hline \multirow{3}{*}{$\beta$-caroteno } & $1 \mathrm{~b}$ & 7,439 \\
\cline { 2 - 3 } & $2 \mathrm{~b}$ & 8,502 \\
\cline { 2 - 3 } & $3 \mathrm{~b}$ & 5,313 \\
\hline \multirow{3}{*}{ clorofila a } & $1 \mathrm{c}$ & 3,707 \\
\cline { 2 - 3 } & $2 \mathrm{c}$ & 4,634 \\
\cline { 2 - 3 } & $3 \mathrm{c}$ & 4,634 \\
\hline \multicolumn{2}{|c}{ Fonte: Elaborada pela autora }
\end{tabular}

\subsubsection{Medida dos efeitos da irradiação por absorção no IR}

Os espectros de absorbância no IR obtidos de uma das replicatas durante as irradiações com luz UVC dos pigmentos Clorofila a e $\beta$-caroteno são mostrados, respectivamente, nas Figuras 41 e 42. Os resultados das outras amostras testadas se mostraram qualitativamente semelhantes.

Os espectros IR são cortados em $\sim 1300 \mathrm{~cm}^{-1}$ devido à absorção do substrato (lamínula de vidro) nesta região. Comparando ambos os espectros com os da literatura e os das mesmas amostras em pó analisadas anteriormente, pode-se observar que os espectros dos filmes são mais parecidos com os das amostras puras ( $\beta$-caroteno puro e clorofila a extraída da Spirulina), e não há grandes diferenças entre elas exceto pequenas variações nas posições dos picos.

Pode-se observar que não há um padrão claro de diminuição das intensidades dos picos IR em função do tempo de irradiação. Isso pode ser explicado pela inomogeneidade dos filmes das amostras, somado com a variação experimental entre as medidas ex situ nos equipamentos de bancada. Entretanto, durante a irradiação há um pico do $\beta$-caroteno e dois picos da clorofila que, descontada uma linha de base, variam de intensidade, o que pode estar associado à quebra ou formação de ligação.

$\mathrm{O}$ pico mencionado do $\beta$-caroteno está centrado em $\sim 1675 \mathrm{~cm}^{-1}$, frequência associada à deformação axial da ligação $C=C$. É possível observar que ele diminui em função da irradiação 
até sumir completamente já a partir de 3 horas de irradiação, o que pode indicar a quebra das duplas ligações.

Um dos picos mencionados da clorofila a diminuiu de intensidade até sumir nos últimos espectros, e está centrado em $\sim 1658 \mathrm{~cm}^{-1}$, que pode estar associado às deformações axiais das ligações $\mathrm{C}=\mathrm{C}$ ou $\mathrm{C}=\mathrm{N}$. E o outro pico aumentou em intensidade em função da irradiação, e está centrado em $1596 \mathrm{~cm}^{-1}$, que pode estar associado à deformação angular da ligação N-H em aminas secundárias. Isso confirmaria uma quebra do sistema conjugado do anel tetrapirrólico, eliminando os metais coordenados no centro pelos átomos de nitrogênio e dando lugar às ligações N-H.

Ambas as variações nos espectros eram esperadas pela análise visual da coloração das amostras, que diminuíram de intensidade em função da irradiação com luz UVC, confirmando, assim, a relação entre a coloração dos pigmentos com seus sistemas conjugados de duplas ligações.

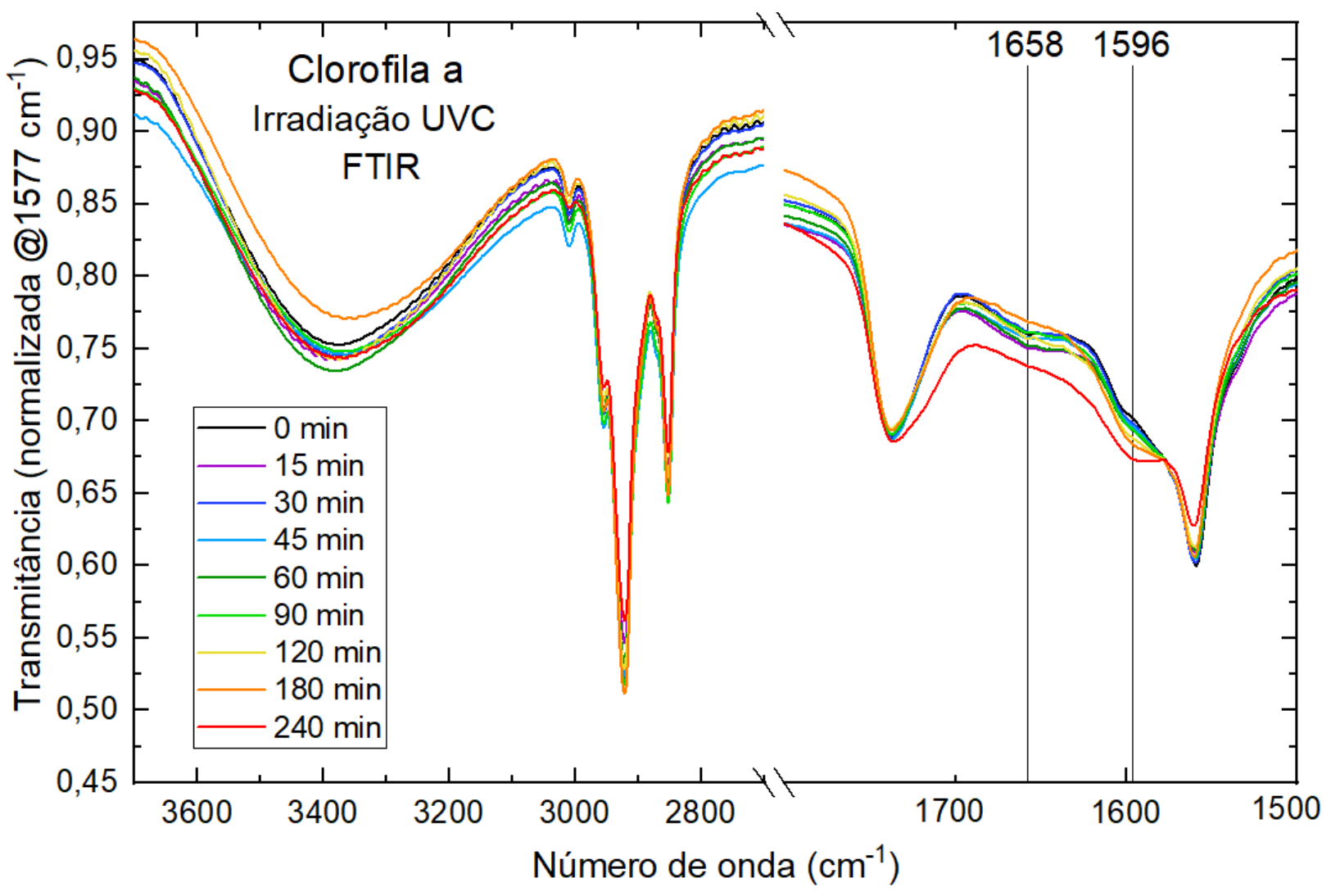

Figura 41 - Espectros de absorbância no IR obtidos durante as irradiações com luz UVC de filmes de clorofila a. Fonte: Elaborada pela autora 


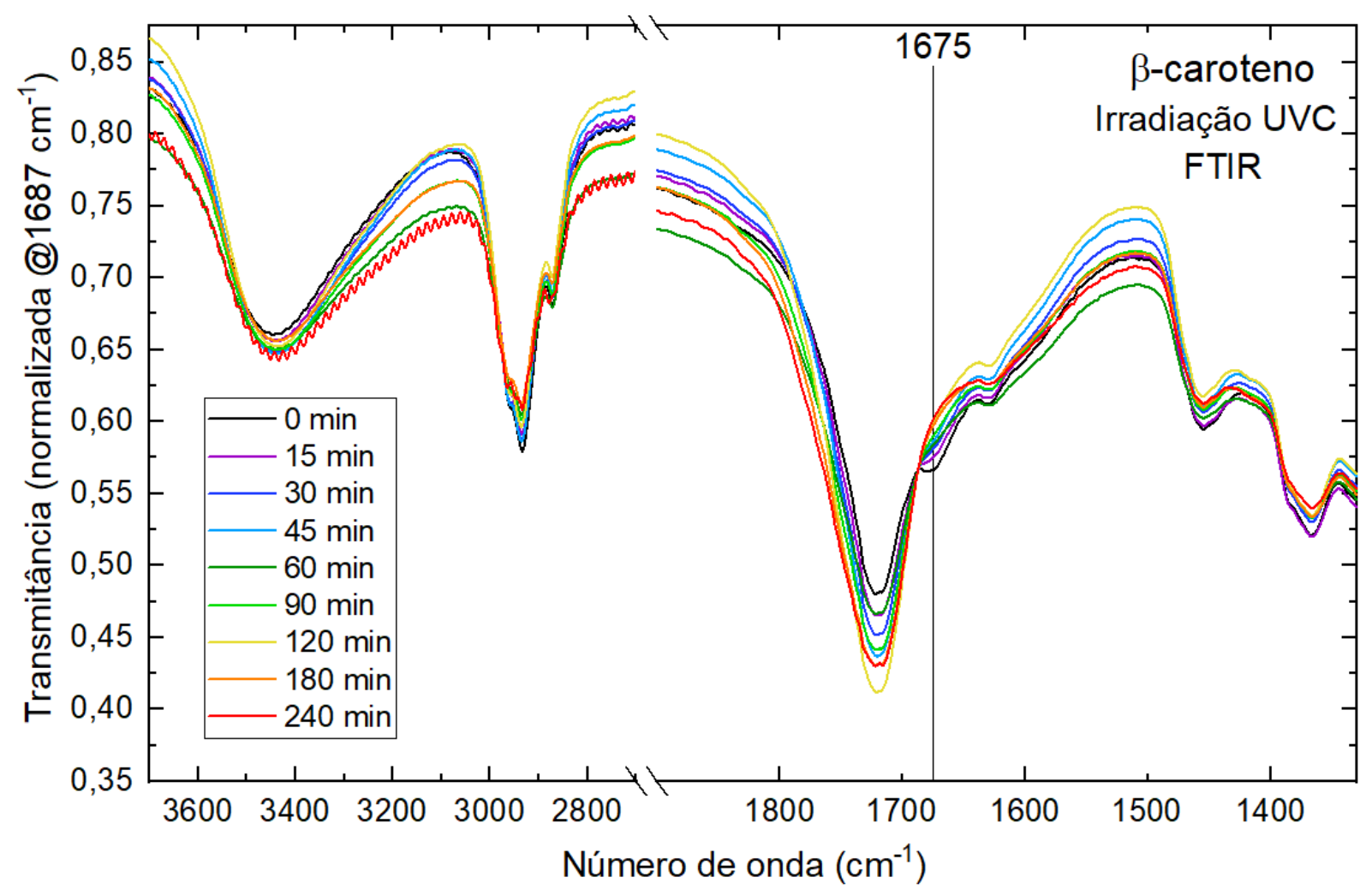

Figura 42 - Espectros de absorbância no IR obtidos durante as irradiações com luz UVC de um filme de $\beta$ caroteno.

Fonte: Elaborada pela autora

\subsubsection{Medida dos efeitos da irradiação por absorção no UV-Vis}

Os espectros de absorbância no UV-vis obtidos de uma das replicatas durante as irradiações com luz UVC dos pigmentos Clorofila a e $\beta$-caroteno são mostrados, respectivamente, nas

\section{Figuras 43 e 44.}

As bandas esperadas para a clorofila a estão presentes em todos os espectros, com as posições em $\sim 420$ e $\sim 660 \mathrm{~nm}$ próximas às esperadas para a clorofila a pura segundo os espectros da literatura, devido à purificação prévia da amostra em etanol. E os picos esperados para o $\beta$ caroteno estão presentes em $\sim 457$ e $\sim 490 \mathrm{~nm}$, mas dificilmente resolvidos entre si em todos os espectros.

Nos dois casos é possível observar mudanças na absorbância da amostra em função do tempo de irradiação. Porém, os valores das absorbâncias acima de 1 já indicam que os filmes produzidos não são opticamente finos. 


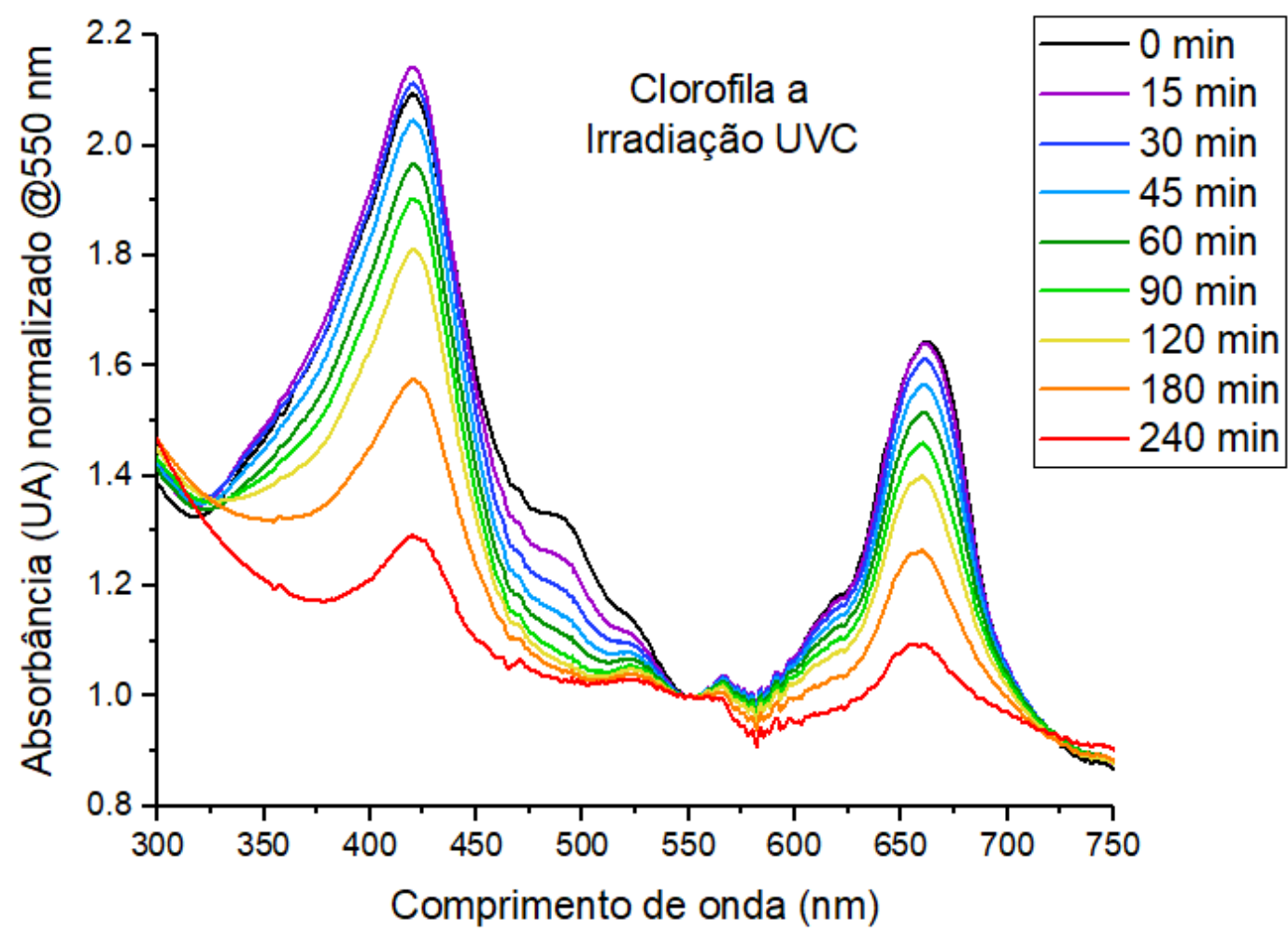

Figura 43 - Espectros de absorbância no UV-vis obtidos durante as irradiações com luz UVC de um filme de Clorofila a.

Fonte: Elaborada pela autora

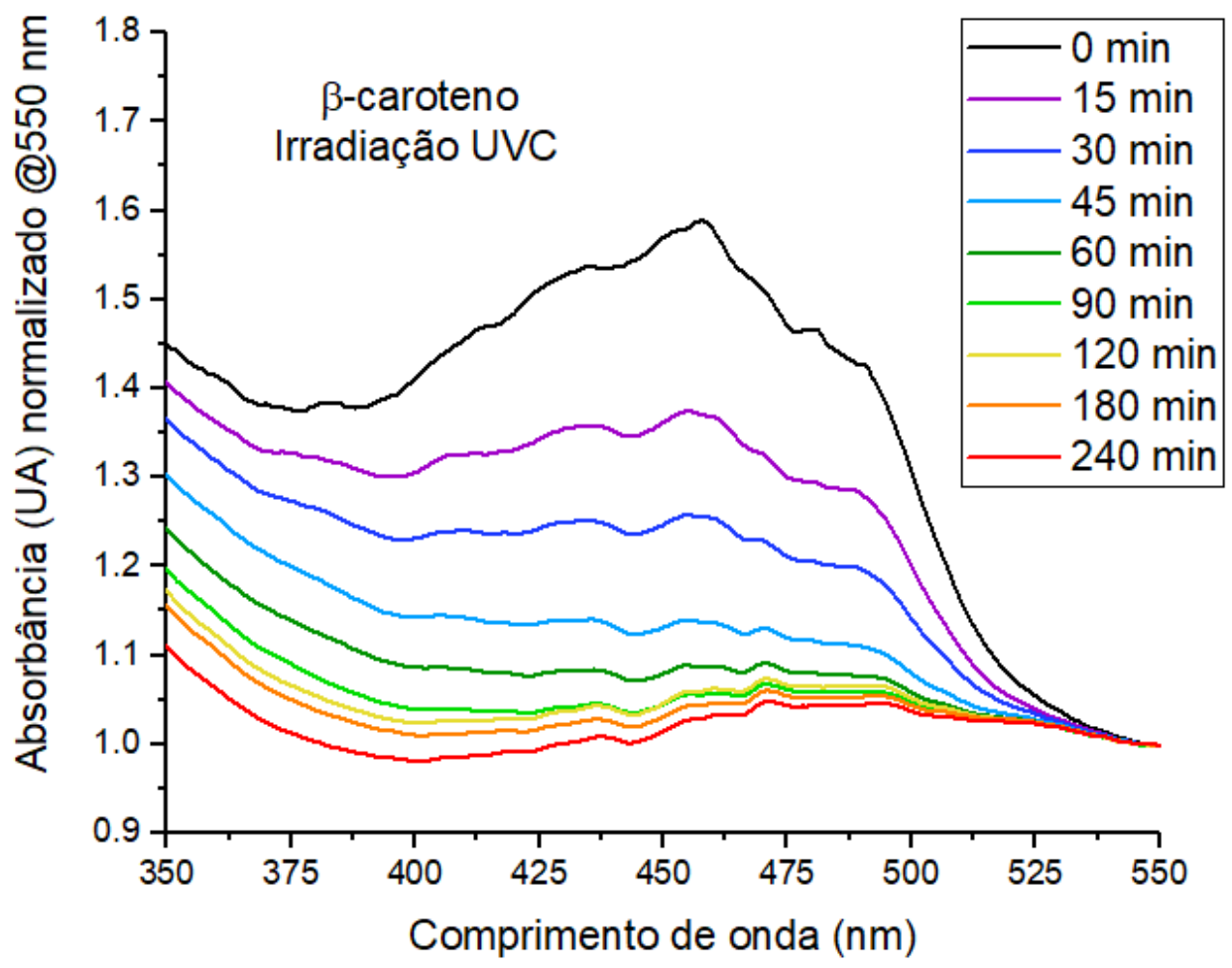

Figura 44 - Espectros de absorbância no UV-vis obtidos durante as irradiações com luz UVC de filmes de $\beta$ caroteno. 
4.2.1.4 Análise dos limites de detecção - espectros de absorbância no UV-Vis

Os limites de detecção das bandas de absorção no UV-vis das amostras foram baseados na diminuição de suas intensidades em função do tempo de radiação.

Como os espectros de absorbância não possuem uma linha de base constante - devido à variação experimental na obtenção de cada espectro - uma reta foi traçada utilizando dois pontos (pontos 0 e 2) nas extremidades da banda de interesse (centrada no ponto 1), como no exemplo mostrado na Figura 45. Com os coeficientes da reta, é encontrado o valor de y no ponto 3 , onde $\mathrm{x}_{3}=\mathrm{x}_{1}$, e o delta em absorbância $(\Delta \mathrm{A})$, ou seja, a intensidade da banda, é encontrado pela subtração: $\mathrm{y}_{3}-\mathrm{y}_{1}$.

Os valores de $\Delta \mathrm{A}$ são, então, normalizados pelo valor máximo, de modo a obter a intensidade da banda em relação à intensidade máxima (no início), em função do tempo de irradiação. Os gráficos nas Figuras 46, 47 e 48 mostram os resultados desses cálculos para as amostras de clorofila a e $\beta$-caroteno.

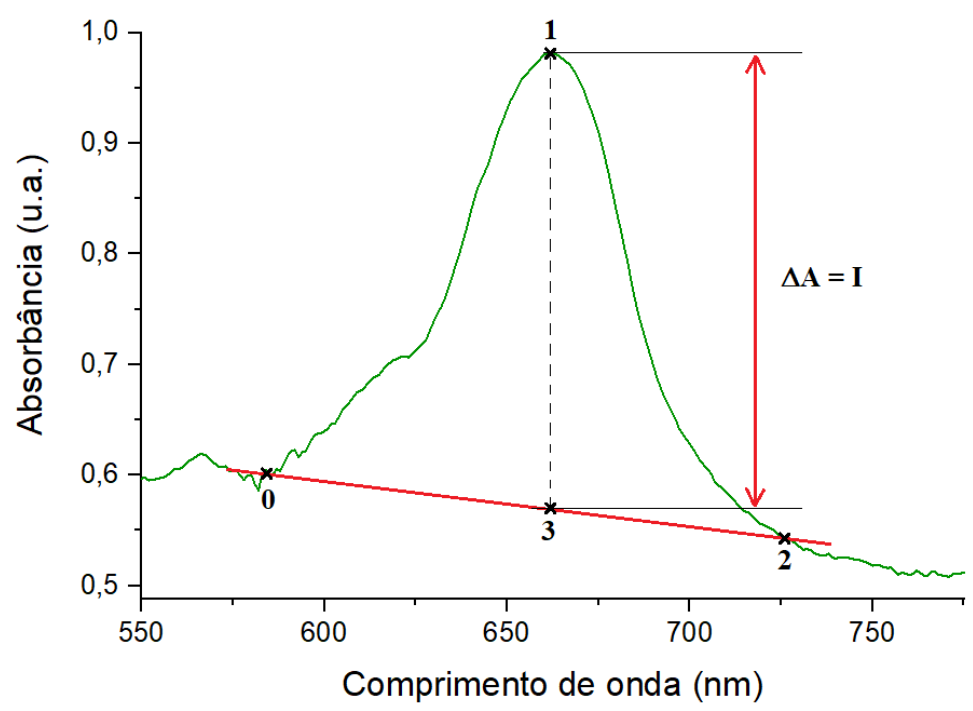

Figura 45 - Esquema de cálculo da intensidade das bandas, utilizando como exemplo uma das bandas da clorofila a (centrada em $\sim 660 \mathrm{~nm}$ ).

Fonte: Elaborada pela autora

Como já esperado, os gráficos de diminuição da intensidade da banda dos pigmentos não puderam ser ajustados por uma função exponencial simples (equação 3), como seria esperado para um filme opticamente fino de uma amostra pura.

Os gráficos das bandas da clorofila a apresentaram uma diminuição com perfil bastante diferente de uma exponencial, confirmando que, além do filme não ser fino, a amostra não estava pura mesmo depois da extração em etanol. Tais curvas só puderam ser ajustada por um 
polinômio de primeiro ou segundo grau, conferindo aos limites de detecção um decaimento quase linear.

Foi possível, então, extrapolar os valores de tempo (x) a partir da equação dada pelo ajuste, até o ponto em que a intensidade da banda (y) chega em $1 \%$, ou seja, quando ela é quase completamente extinta. Para a banda em $420 \mathrm{~nm}$, a média entre os valores encontrados para x foi de $\sim 260,7 \pm 19,0 \mathrm{~min}$, e para a banda em $660 \mathrm{~nm} \sim 289,1 \pm 31,2 \mathrm{~min}$. Ou seja, ambas as bandas seriam extintas em pouco tempo após o término dessas irradiações.

As curvas de extinção da banda do $\beta$-caroteno puderam ser ajustadas por uma exponencial de decaimento, mas com um termo independente, dada por:

$$
y=y_{0}+A_{1} e^{-x / t_{1}}
$$

Onde $1 / t_{1}$ é a taxa de extinção da banda.

As taxas de extinção das bandas do $\beta$-caroteno foram calculadas e a média dos valores encontrados foi de $0,0537 \pm 0,0126 \mathrm{~min}^{-1}$.

Pode-se observar que as intensidades das bandas do $\beta$-caroteno diminuíram rapidamente, chegando em $\sim 20 \%$ da intensidade em $\sim 45$ minutos, indicando uma rápida cinética de degradação por luz UVC. E um platô foi atingido pouco tempo depois, quando o decaimento se tornou mais lento. Uma possível explicação para este comportamento seria que as moléculas que estão sendo degradadas estão formando uma camada de produtos na superfície da amostra, absorvendo mais a luz UV incidente e blindando a amostra, o que diminui a velocidade da degradação. Este efeito já foi reportado anteriormente, chamado de "shielding effect". (98), (99)

Adotando a tendência da região onde o decaimento é mais lento e assumindo que ela é constante, um outro ajuste foi feito utilizando uma equação exponencial simples, dada por $y=$ $a e^{b x}$. A curva foi extrapolada e foi possível encontrar o valor de $\mathrm{x}$ para $\mathrm{y}=1 \%$. O tempo calculado necessário para extinguir completamente a banda do $\beta$-caroteno em uma irradiação com luz UVC foi de 1085,5 $\pm 594,9$ min. 


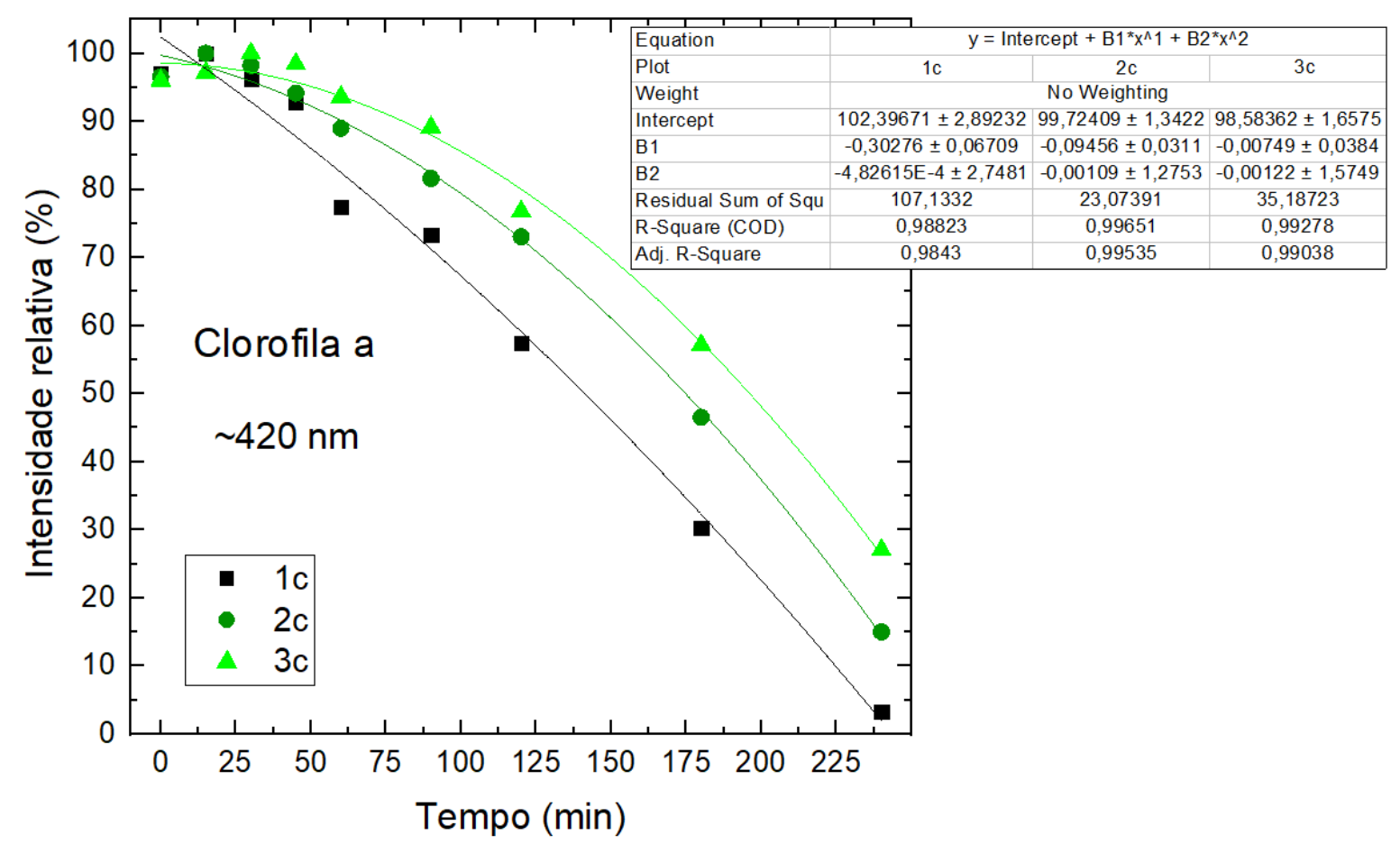

Figura 46 - Intensidade da banda em 420 nm das 3 replicatas (1c, 2c e 3c) da clorofila a em relação à intensidade máxima em função do tempo de irradiação com luz UVC, e ajustes polinomiais das curvas.

Fonte: Elaborada pela autora

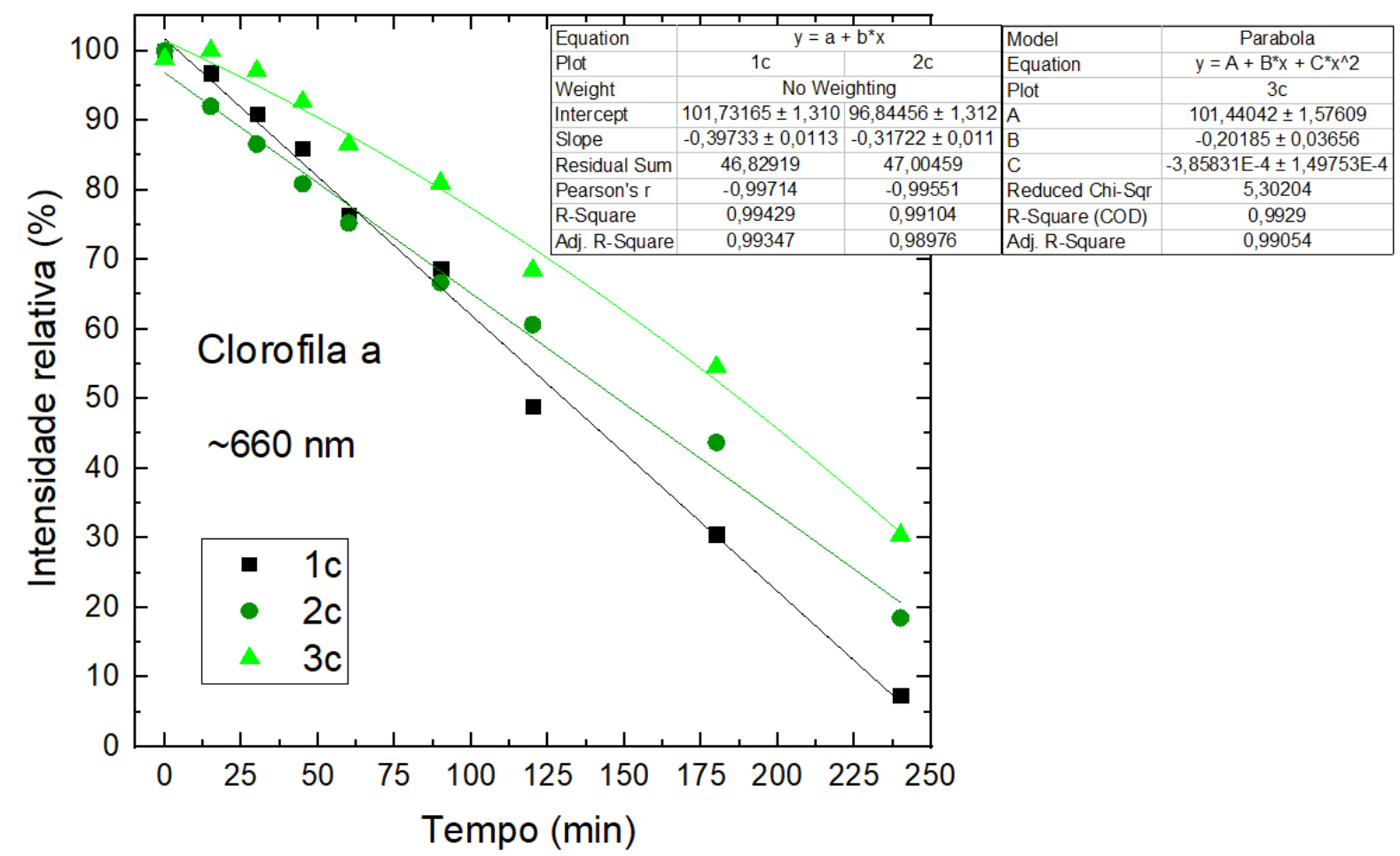

Figura 47 - Intensidade da banda em 660 nm das 3 replicatas (1c, 2c e 3c) da clorofila a em relação à intensidade máxima em função do tempo de irradiação com luz UVC, e ajustes polinomiais das curvas.

Fonte: Elaborada pela autora 


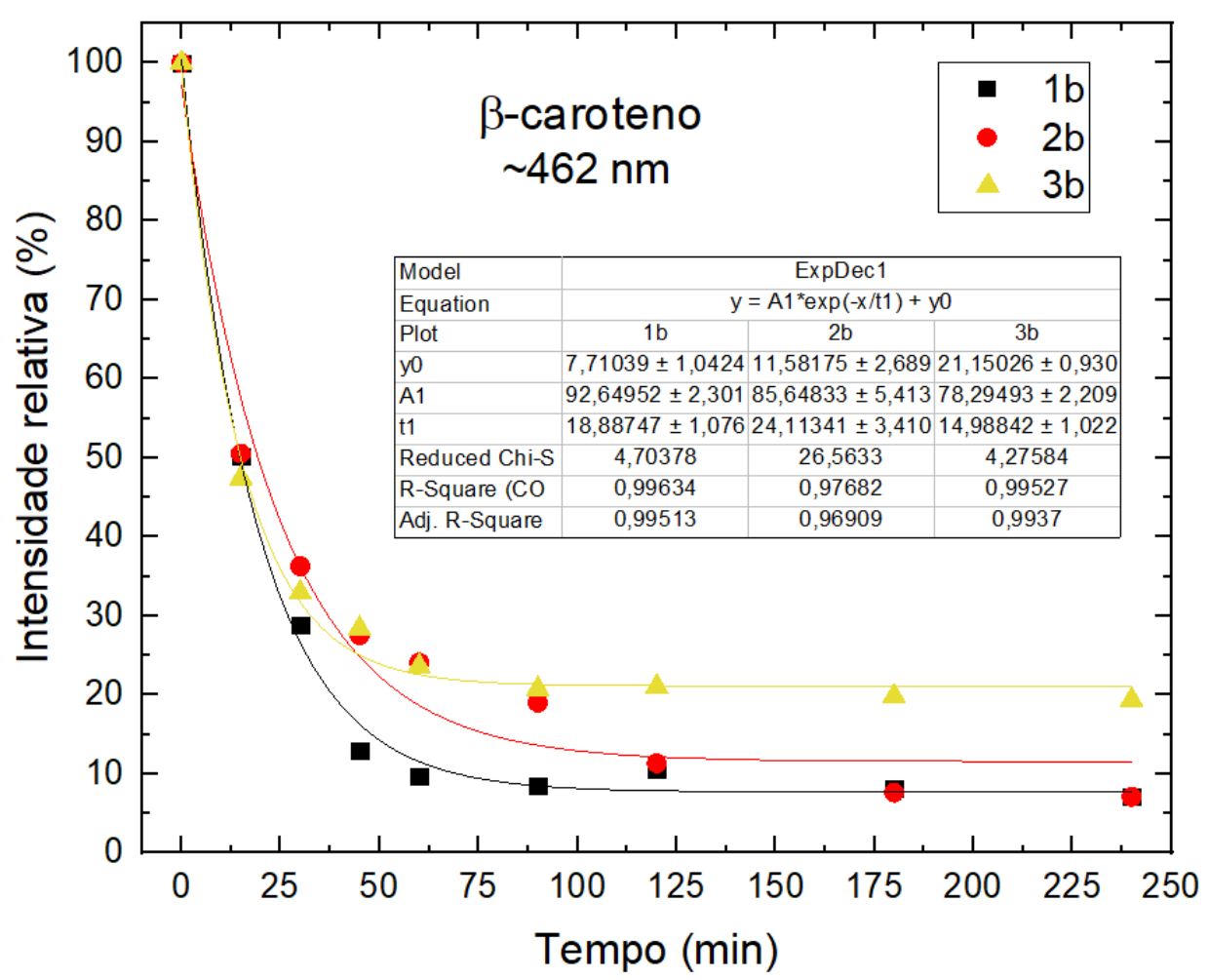

Figura 48 - Intensidade da banda em 462 nm em 3 replicatas (1b, 2b e 3b) do $\beta$-caroteno em relação à intensidade máxima, em função do tempo de irradiação com luz UVC, e ajustes exponenciais das curvas.

Fonte: Elaborada pela autora

\subsubsection{AstroCam}

\subsubsection{Medida dos efeitos da irradiação por reflectância no UV-Vis}

Primeiramente, o comportamento da lâmpada foi monitorado utilizando apenas um quadrado de Alumínio + Prata (super-refletivo) no lugar da amostra, para garantir que seu espectro não variaria significativamente com o tempo e, assim, poder ser utilizada como fonte para a espectroscopia in situ. Foi, então, confirmado que o perfil de seu espectro não apresentou grandes variações, além de uma pequena oscilação nas contagens do detector dos espectros como um todo (espectros no Apêndice).

Além disso, algumas amostras foram selecionadas como candidatas a "branco", para serem usadas tanto para a obtenção de espectros de referência, quanto para diluir opticamente as amostras de pigmentos e evitar a saturação do detector. Tais amostras foram irradiadas no simulador solar para garantir que não houvesse degradação delas durante os experimentos, evitando uma interferência na degradação das amostras. A amostra selecionada como branco 
foi o sulfato de bário $\left(\mathrm{BaSO}_{4}\right)$, cujo espectro não apresentou variações em seu perfil além da oscilação já confirmada da lâmpada (espectros no Apêndice). Os outros brancos testados apresentavam, após certo tempo de irradiação, bandas de absorção que não haviam no início, o que foi atribuído a uma degradação das amostras.

Finalmente, a amostra do pigmento $\beta$-caroteno (da cenoura), diluído opticamente em sulfato de bário, foi irradiada durante quase duas horas. Os espectros a cada 15 minutos são mostrados na Figura 49.

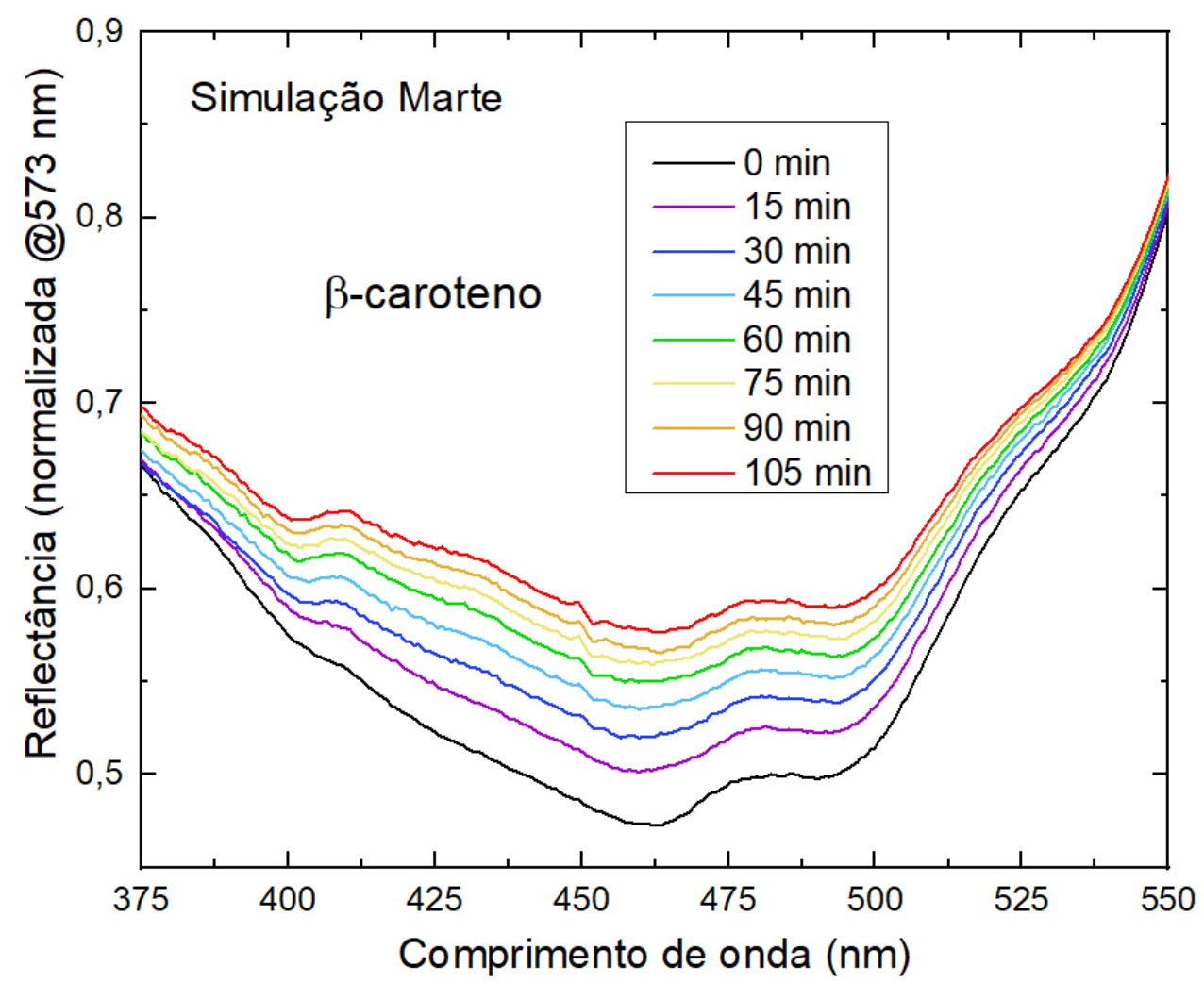

Figura 49 - Espectros obtidos no UV-vis do $\beta$-caroteno irradiado na AstroCam em simulação da superfície marciana.

Fonte: Elaborada pela autora

\subsubsection{Análise dos limites de detecção - espectros de reflectância no UV-Vis}

Os limites de detecção das bandas de absorção no UV-vis das amostras também foram baseados na diminuição de suas intensidades em função da fluência de radiação UVC.

Os espectros de reflectância obtidos neste experimento também não possuem uma linha de base constante - devido à oscilação da lâmpada - e, portanto, as análises foram feitas da mesma maneira que para as amostras irradiadas com lâmpadas UVC (seção 4.2.1.4). 
Os valores de delta em reflectância $(\Delta \mathrm{R})$ foram, então, normalizados pelo valor máximo, de modo a obter a intensidade da banda em relação à intensidade máxima (no início), em função do tempo de irradiação (convertido posteriormente para fluência de radiação UVC). A Figura 50 mostra os resultados desses cálculos para a amostra de $\beta$-caroteno diluída opticamente em sulfato de bário.

Para a conversão do tempo em fluência foi utilizado o valor medido de irradiância na faixa de radiação UVC. A fluência, $F$, em J.m ${ }^{-2}$, pode ser calculada a partir da equação:

$$
F=I t
$$

Onde $I$ é a irradiância da fonte, em W.m², e t é o tempo de irradiação, em segundos.

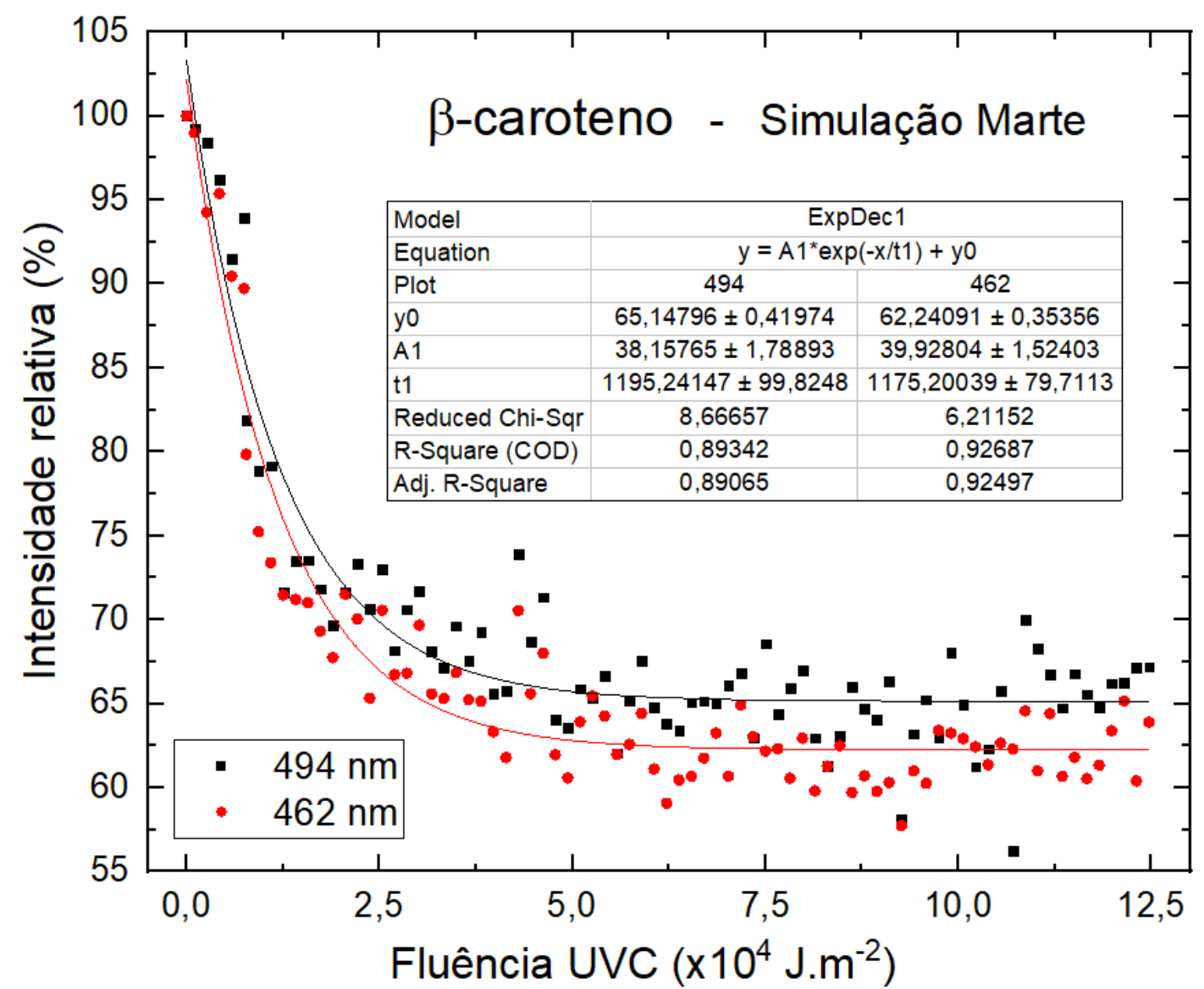

Figura 50 - Intensidade das bandas do $\beta$-caroteno, em 462 e 494 nm, em relação à intensidade máxima, em função do tempo de irradiação na AstroCam, e ajustes exponenciais das curvas.

Fonte: Elaborada pela autora

Novamente, os gráficos de diminuição da intensidade da banda dos pigmentos não puderam ser ajustados por uma função exponencial simples, como seria esperado para um filme opticamente fino de uma amostra pura. As curvas de extinção foram, então, ajustadas pela exponencial de decaimento com termo independente (equação 37). 
As duas bandas apresentaram o mesmo comportamento, ambas com taxas de extinção $\left(1 / \mathrm{t}_{1}\right)$ de $\sim 8,8 \times 10^{-4}\left(\mathrm{~J}^{-\mathrm{m}^{-2}}\right)^{-1}$. E pode-se observar, novamente, que um platô foi atingido a partir de certa fluência $\left(\sim 7 \times 10^{4} \mathrm{~J}^{-\mathrm{m}^{-2}}\right)$, quando o decaimento se tornou consideravelmente mais lento. Tal comportamento parece ser o mesmo observado no experimento anterior (irradiação com UVC), reforçando a hipótese de que as moléculas de $\beta$-caroteno tem uma cinética rápida quando irradiadas, e tendem a formar uma camada protetora que diminui ou até impede a degradação das moléculas inferiores.

Da mesma forma que no experimento anterior, foi adotada a tendência da região onde o decaimento é mais lento e, assumindo que ela é constante, outro ajuste foi feito com os últimos pontos (a partir da fluência $\sim 7 \times 10^{4} \mathrm{~J} \mathrm{~m}^{-2}$ ), utilizando a equação exponencial simples. A fluência calculada necessária para extinguir completamente a banda do $\beta$-caroteno ( $1 \%$ da intensidade inicial) em uma irradiação com luz UVC na superfície de Marte foi de $\sim 1,82 \times 10^{6} \mathrm{~J}^{-\mathrm{m}^{-2}}$ para a banda em $462 \mathrm{~nm}$, e de $~ 5,31 \times 10^{6} \mathrm{~J}^{-\mathrm{m}^{-2}}$ para a banda em $494 \mathrm{~nm}$.

\subsubsection{Comparando com a radiação em ambientes reais}

A fluência da radiação UVC obtida na AstroCam pode, então, ser comparada com a fluência de radiação UVC no ambiente real da superfície de Marte. Com isso, pode-se calcular quanto tempo demoraria para as bandas das amostras estudadas receberem a fluência de luz UVC que as extinguiria se as amostras estivessem presentes na superfície de Marte.

Para isso, foi utilizado o modelo SOLAR2000 da irradiância da radiação solar que chega na superfície terrestre, em função do comprimento de onda, mostrado na Figura 51. (100)

É possível calcular a irradiância que chega em qualquer superfície do Sistema Solar, $H_{0}$, a partir da relação:

$$
H_{0}=H_{\text {sol }} \frac{R_{\text {sol }}^{2}}{D^{2}}
$$

Onde $H_{\text {sol }}$ é a irradiância solar na superfície do Sol em W.m ${ }^{-2}, R_{\text {sol }}$ é o raio do Sol em metros, e $D$ é a distância entre o sol e a superfície de interesse, em metros. 


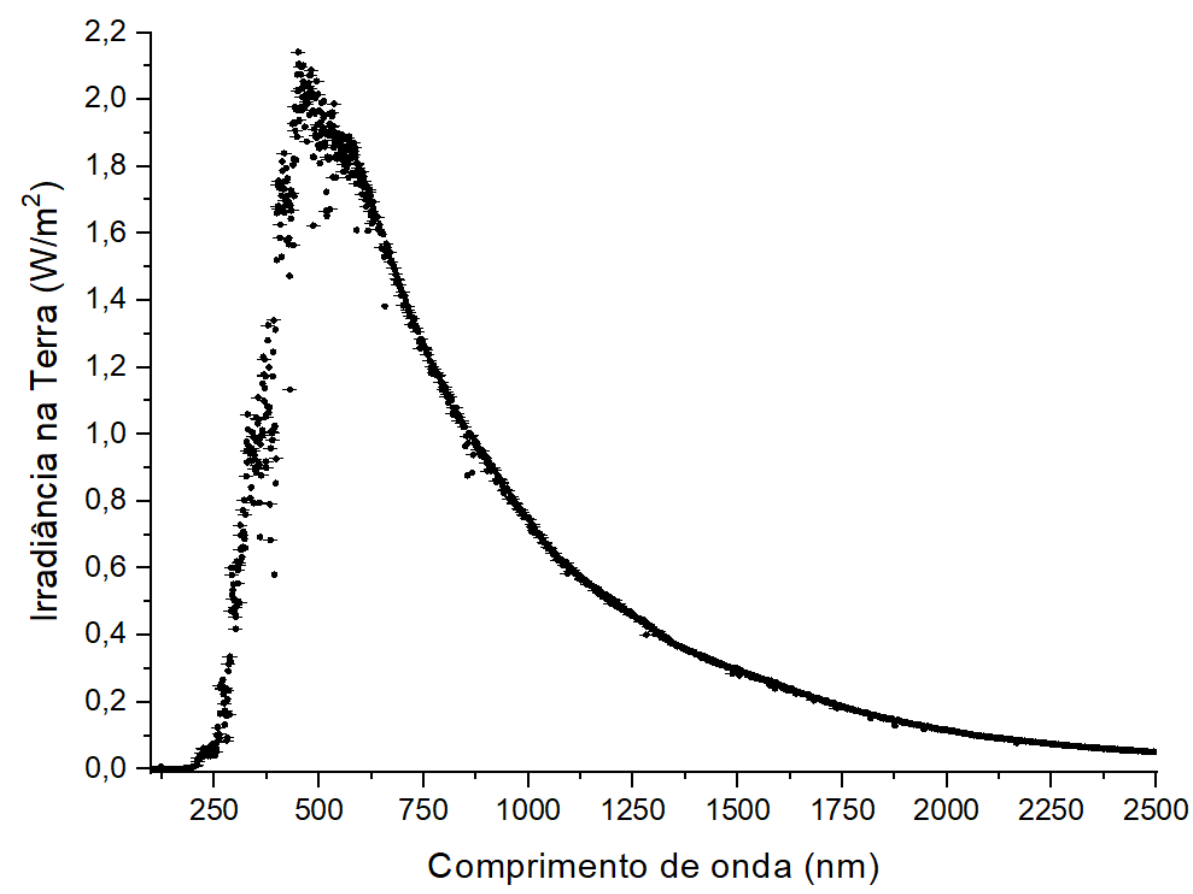

Figura 51 - Irradiância da radiação solar que chega na superfície terrestre, em função do comprimento de onda, de acordo com o modelo SOLAR2000.

Fonte: TOBISKA et al. (100)

Considerando a distância de Marte até o Sol como 2,279x $10^{11} \mathrm{~m}$, foi calculada a irradiância em função do comprimento de onda que chega nessa superfície. E, então, considerando que a região de maior importância da radiação no experimento na AstroCam é do UVC (entre 200 e $280 \mathrm{~nm}$ ), as irradiâncias foram integradas nesta região, resultando no valor de irradiância:

- Irradiância UVC na Superfície de Marte = 2,889 W.m²

Portanto, o tempo que levaria para atingir a fluência necessária para extinguir completamente as bandas do $\beta$-caroteno presente e sendo irradiado por luz UVC na superfície de Marte, seria $\sim$ 175,0 horas para a banda em $462 \mathrm{~nm}$, e de 510,5 horas para a banda em $494 \mathrm{~nm}$.

\subsubsection{Radiação síncrotron - Linha de luz TGM (LNLS)}

\subsubsection{Cálculo da fluência da radiação sincrotron}

Os cálculos de fluência para os experimentos de irradiação na linha de luz TGM não são triviais por conta da utilização do feixe branco (policromático), do desalinhamento da ótica da linha com o tempo e da variação temporal da corrente do feixe de radiação síncrotron do UVX.

A grade toroidal utilizada nesse experimento foi a grade 1 da TGM, recoberta de platina, posicionada a um ângulo de aproximadamente $9^{\circ}$ com relação ao feixe incidente, otimizando a ótica da linha para a região de 3 a $13 \mathrm{eV}$ (apesar de passarem fótons com todas as energias 
quando se utiliza o feixe branco). O gráfico de refletividade de um espelho de Pt em função da energia do fóton incidente, a este ângulo, foi obtido usando as equações de Fresnel para um meio semi-infinito (Figura 52). (101) A partir desse gráfico é possível obter o valor de cut off para a refletividade da grade, que se dá no ponto de máxima inclinação, correspondente aos fótons com aproximadamente $152 \mathrm{eV}$ de energia. Assume-se, portanto, que os fótons que chegaram na amostra possuíam no máximo esta energia, ou seja, a região efetiva para os cálculos de fluxo é de 3 a $152 \mathrm{eV}(\sim 413$ a 8 nm).

O gráfico da Figura 53 mostra medidas de corrente do feixe síncrotron (monocromático) pelo fotodiodo utilizado, em função da energia dos fótons incidentes, utilizando a grade 1 na linha TGM. A variação acima de $11 \mathrm{eV}$ é devido ao feixe estar incidindo na borda da grade. De modo a obter a corrente na região de interesse ( 3 a $152 \mathrm{eV})$ um ajuste linear foi feito na região de 5 a $11 \mathrm{eV}$, obtendo uma equação de reta da corrente, $I(E)$, em função da energia do fóton, $E$. O gráfico foi extrapolado para a região de 3 a $152 \mathrm{eV}$, a qual foi, então, integrada de modo a obter uma corrente do feixe monocromático, $I_{\text {mono }}$ (equação 40 ).

$$
I_{\text {mono }}=\int_{3}^{152} I(E) d E=\int_{3}^{152} 1,48914 \cdot 10^{-8} \cdot E-7,60307 d E
$$

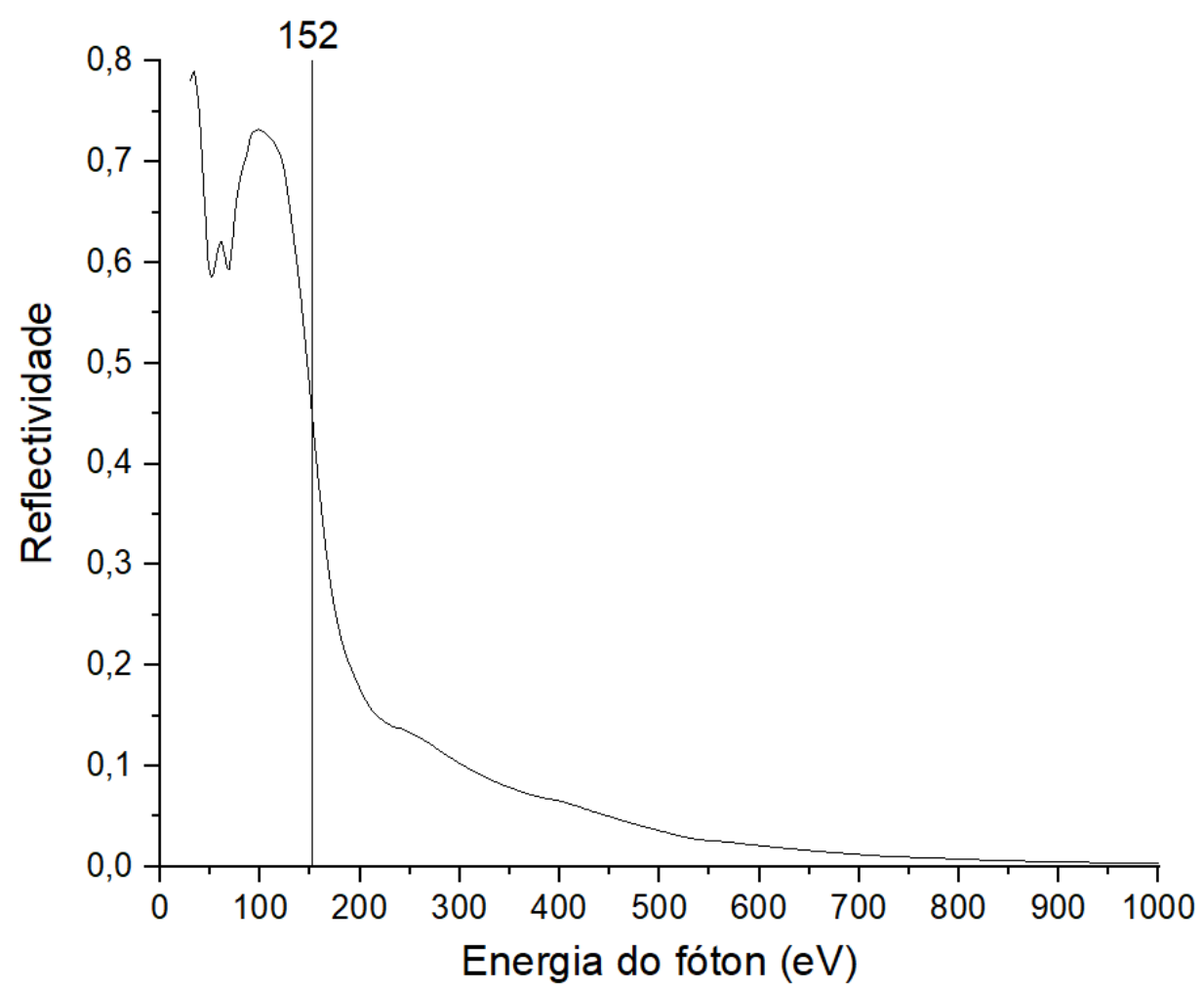

Figura 52- Gráficos da refletividade de um espelho de Pt em função da energia do fóton incidente. Fonte: Elaborada pela autora 


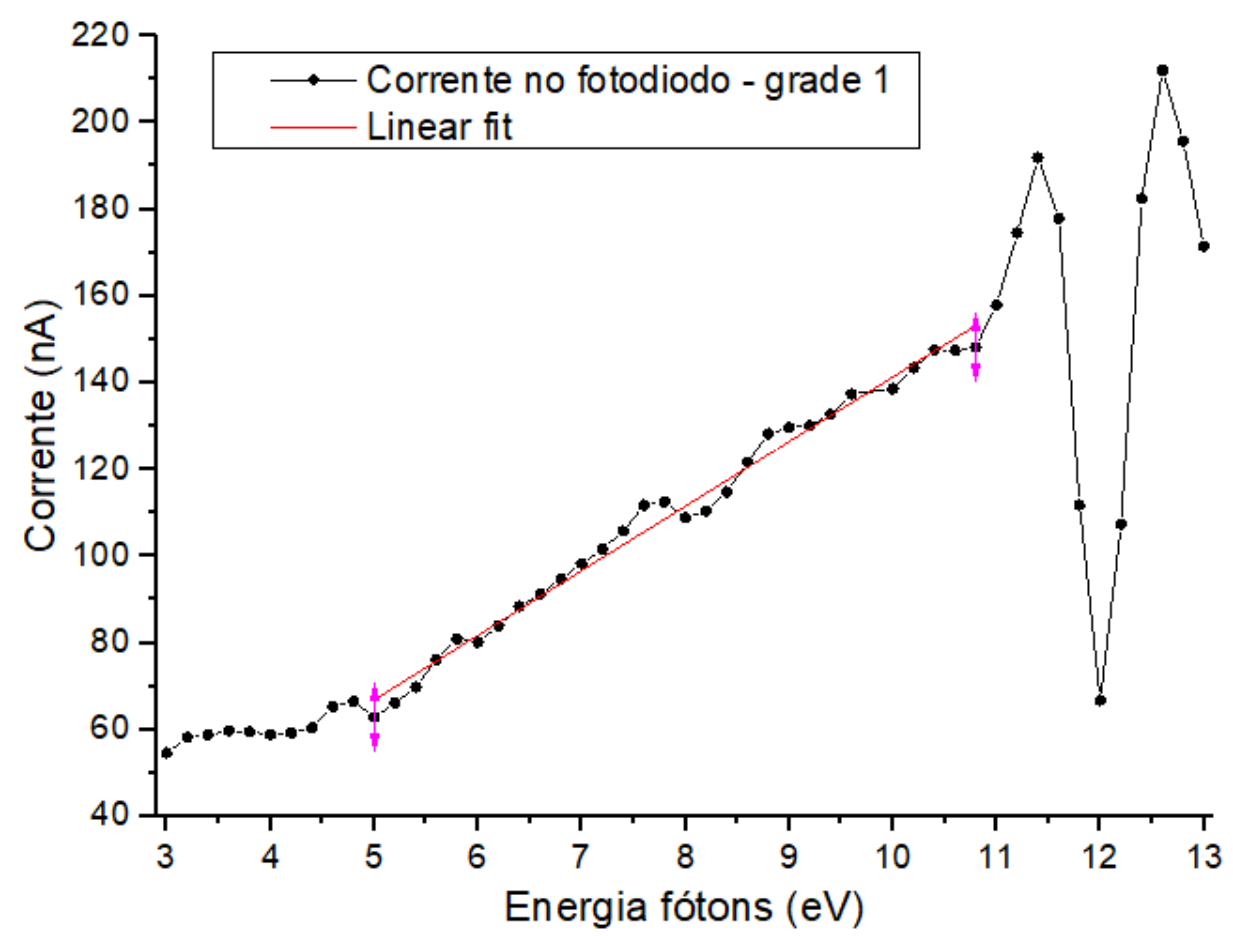

Figura 53 - Medidas de corrente do feixe síncrotron pelo fotodiodo utilizado. Fonte: Elaborada pela autora

No momento de cada irradiação, a corrente total (equação 41) pode ser dada pela corrente dependente da energia dos fótons, $I(E)$, dada pela equação obtida anteriormente, dividida pela eficiência quântica (ou responsividade) do fotodiodo em função da energia do fóton, $Q E(E)$, em A.W ${ }^{-1}$, fornecida pela fabricante (mostrado na Figura 54). Além disso, deve ser multiplicada por um fator de correção, dado pela média da corrente do feixe policromático medida pelo fotodiodo antes e após o experimento de irradiação, $I_{\text {poli }}$, dividida pela corrente do feixe monocromático integrada na região de interesse, $I_{m o n o}$.

$$
I_{\text {total }}=\frac{I(E)}{Q E(E)} \frac{I_{\text {poli }}}{I_{\text {mono }}}
$$

Assim, o fluxo de radiação sincrotron em função da energia dos fótons, $R(E)$, incidente em uma área, $A$, da amostra, pode ser calculado pela equação 42 . E o fluxo total, dado em $\mathrm{W} / \mathrm{m}^{2}$, na região de interesse é calculado pela integral da equação 42 na região de 3 a 152 eV (equação 43).

$$
\begin{gathered}
R(E)=\frac{I(E)}{Q E(E)} \frac{I_{\text {poli }}}{I_{\text {mono }}} \frac{1}{A} \\
R=\frac{I_{\text {poli }}}{I_{\text {mono }}} \frac{1}{A} \int_{3}^{152} \frac{I(E)}{Q E(E)} d E
\end{gathered}
$$




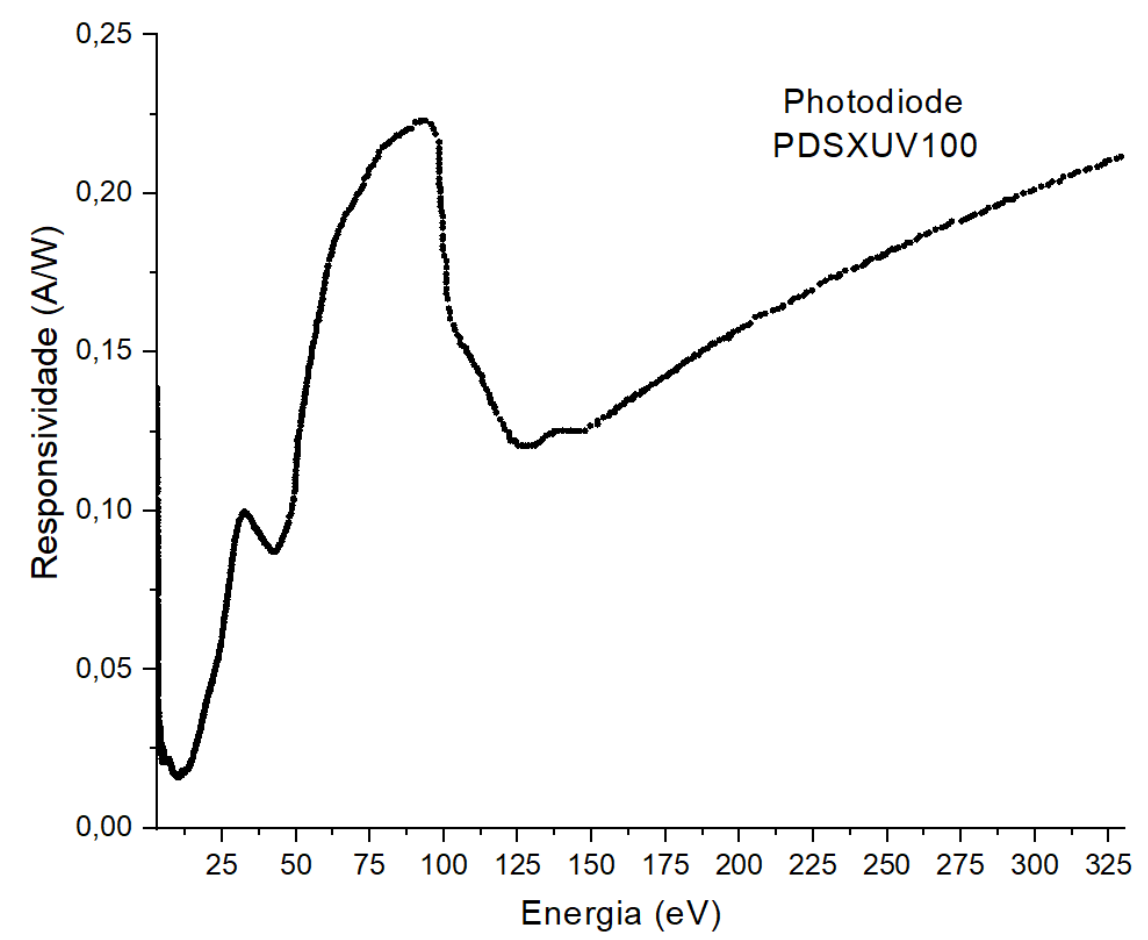

Figura 54 - Eficiência quântica (ou responsividade) do fotodiodo em função da energia do fóton.

Fonte: Elaborada pela autora

Finalmente, para obter a fluência, dada em J.m ${ }^{-2}$, os valores de fluxo são multiplicados pelo tempo, $t$,em segundos:

$$
F=\frac{I_{\text {poli }}}{I_{\text {mono }}} \frac{1}{A} t \int_{3}^{152} \frac{I(E)}{Q E(E)} d E
$$

\subsubsection{Comparando com a radiação em ambientes reais}

A fluência da radiação sincrotron obtida na linha de luz TGM pode, então, ser comparada com a fluência de radiação UV em ambientes reais. Com isso, pode-se calcular quanto tempo demoraria para determinada amostra receber uma certa fluência de luz UV se ela estivesse, por exemplo, na superfície de Marte.

Para isso, foram feitos os mesmos cálculos feitos na seção 4.2.2.3 utilizando o modelo SOLAR2000. (100)

Considerando a distância de Marte até o Sol como $2,279 \times 10^{11}$, foram calculadas as irradiâncias em função do comprimento de onda que chega em cada uma dessas superfícies. E, então, considerando que a maior parte da radiação obtida na linha TGM estava entre 3 e 152 eV (413,3 a 8,2 nm), as irradiâncias foram integradas nesta região, resultando nos valores abaixo:

- Irradiância na Superfície de Marte $=56.03 \mathrm{~W} \cdot \mathrm{m}^{-2}$ 


\subsubsection{Medida dos efeitos da irradiação por reflectância no UV-Vis}

A Figura 55 mostra as pastilhas de amostras dos pigmentos biológicos e substratos após a irradiação com luz sincrotron. Pode-se observar nas pastilhas áreas de cerca de $1 \mathrm{~mm}^{2}$ (onde o feixe foi apontado) com uma mudança na coloração, o que já indica mudanças estruturais nas amostras.

Os espectros de reflectância no UV-vis obtidos durante as irradiações com luz síncrotron dos pigmentos clorofila a e $\beta$-caroteno - tanto "puras" (misturadas somente com o padrão interno pó de diamante) quanto misturadas com diferentes substratos inorgânicos - são mostrados, respectivamente, nas Figuras 56 e 57. Os espectros foram normalizados pela divisão de cada espectro pelo seu valor específico de reflectância correspondente aos fótons de $750 \mathrm{~nm}$ para os espectros de clorofila a e de $600 \mathrm{~nm}$ para os espectros de $\beta$-caroteno.
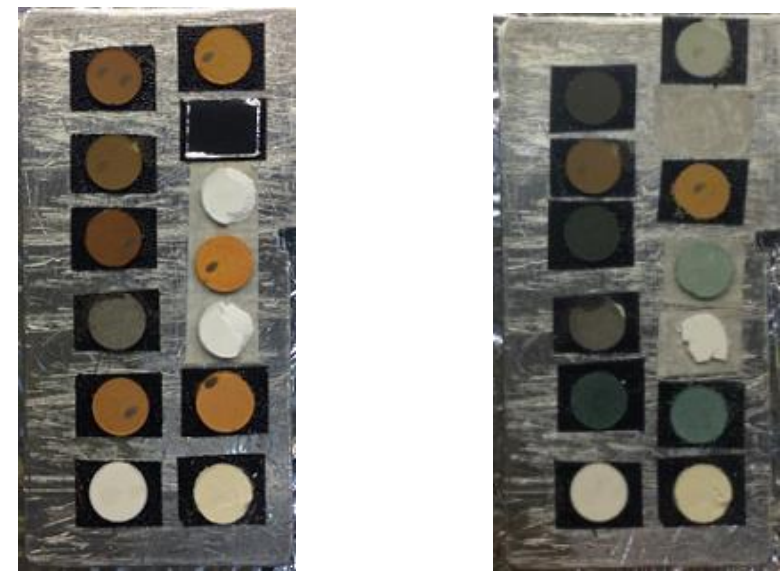

Figura 55 - Esquerda: porta-amostras com pastilhas das amostras de $\beta$-caroteno após a irradiação total. Direita: porta-amostras com pastilhas das amostras de Clorofila a após a irradiação total.

Fonte: Obtida pela autora

O pico esperado para a clorofila a em $\sim 670 \mathrm{~nm}$ está presente em todos os espectros, mas o pico em $\sim 430 \mathrm{~nm}$ não é bem resolvido para algumas amostras. E os picos esperados para o $\beta$ caroteno em 455 e 485 são muito próximos e dificilmente resolvidos entre si. Ambos são visíveis em alguns espectros, enquanto que em outros somente um ou outro pode ser medido. Porém, ambos os picos mostraram um mesmo padrão de degradação e, portanto, somente um deles foi utilizado nas análises posteriores. 

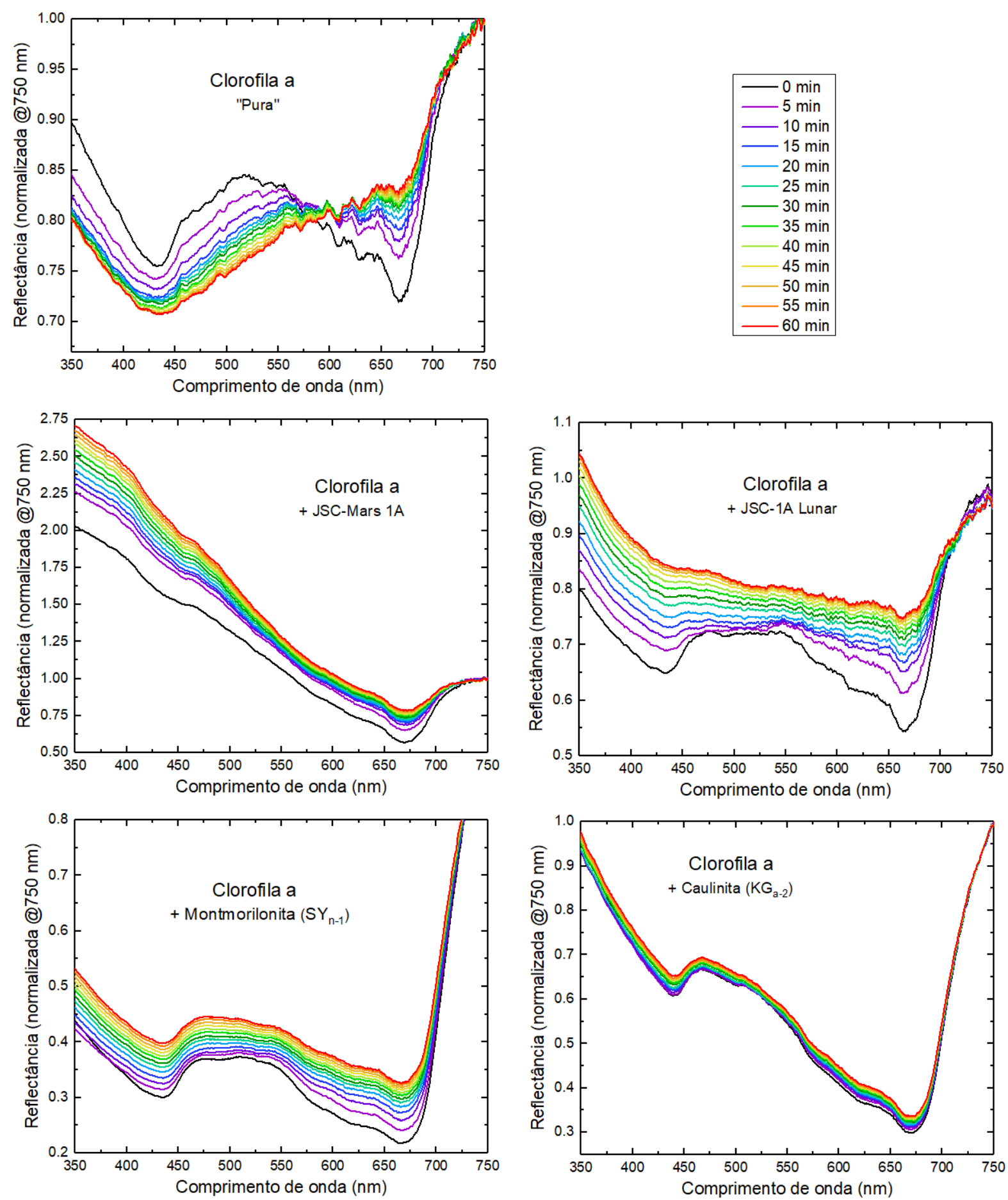

Figura 56 - Espectros de reflectância no UV-vis obtidos durante as irradiações com luz síncrotron de filmes de clorofila a.

Fonte: Elaborada pela autora 

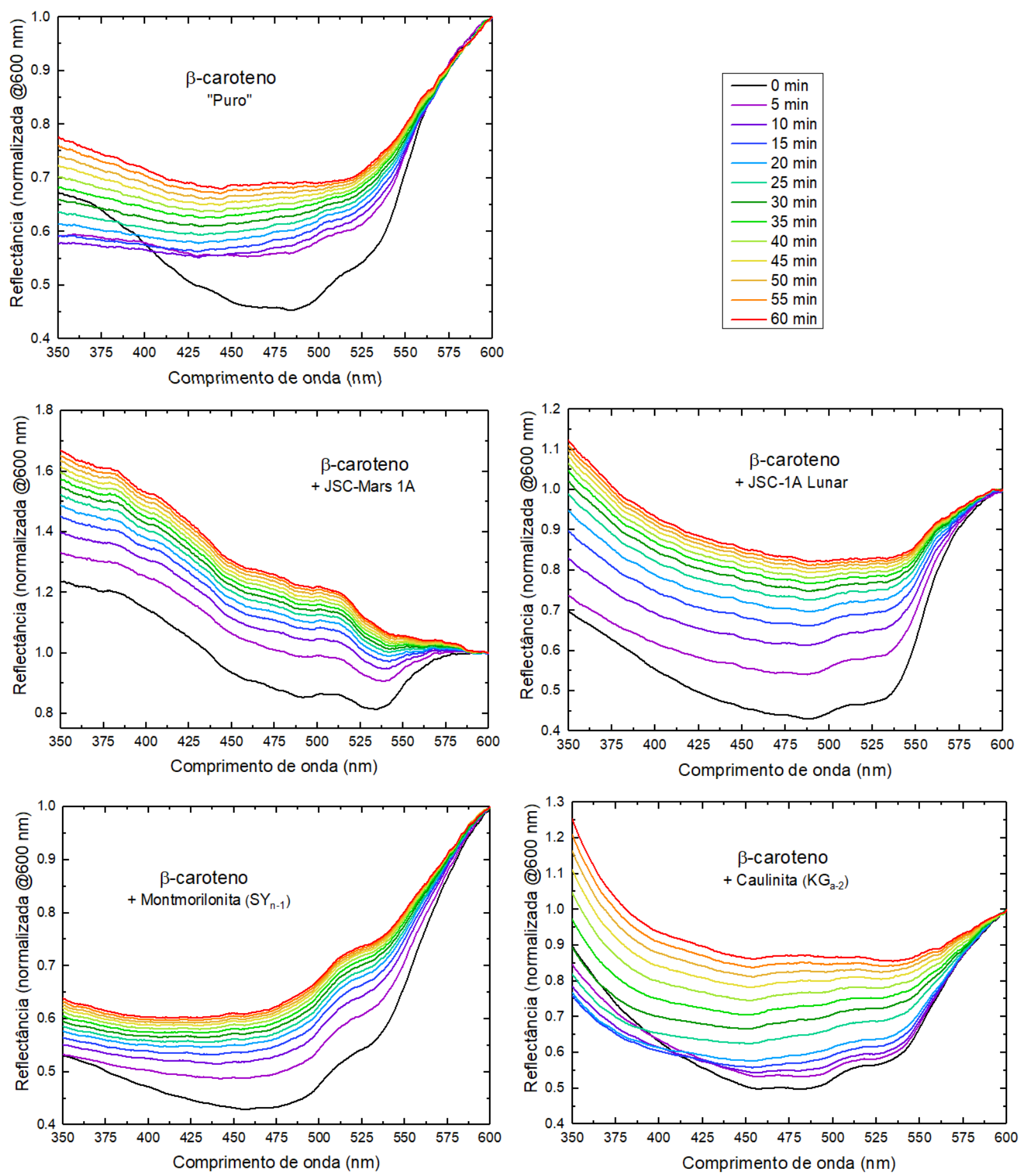

Figura 57 - Espectros de reflectância no UV-vis obtidos durante as irradiações com luz síncrotron de filmes de $\beta$-caroteno.

Fonte: Elaborada pela autora

Em todos os casos é possível observar mudanças na reflectância da amostra em função do tempo de irradiação. Podemos inferir que a diminuição da intensidade dessas bandas indica uma diminuição na quantidade da ligação à qual ela está associada, ou seja, uma quebra dessas ligações. Para analisar estas mudanças, e poder inferir um limite de detecção para as amostras 
em função da fluência recebida, foi feito um cálculo de intensidade de cada uma das bandas (descrito na próxima seção).

Para garantir que qualquer mudança observada nas misturas foi somente devido a mudanças estruturais nos pigmentos biológicos, os substratos inorgânicos também foram irradiados com radiação síncrotron e seus espectros de reflectância no UV-vis monitorados (mostrados no Apêndice).

Pôde-se observar que, na região das bandas dos pigmentos, o perfil dos espectros dos substratos não varia em função do tempo de irradiação, o que confirma que os substratos não apresentaram mudanças em suas absorções após irradiação com luz síncrotron. As únicas variações visíveis são devido à diminuição da intensidade do feixe de luz síncrotron no LNLS em função do tempo, que resulta em uma variação na linha de base dos espectros.

\subsubsection{Análise dos limites de detecção - espectros de reflectância no UV-Vis}

Os limites de detecção das bandas de absorção no UV-vis das amostras também foram baseados na diminuição de suas intensidades em função da fluência de radiação síncrotron.

Como mencionado, os espectros de reflectância difusa obtidos in situ durante os experimentos na TGM também não possuem uma linha de base constante - devido à variação na intensidade do feixe de luz síncrotron no LNLS. Com o objetivo de descontar este efeito, as análises foram feitas da mesma maneira que para as amostras irradiadas com lâmpadas UVC (seção 4.2.1.4).

Os valores de delta em reflectância $(\Delta \mathrm{R})$ foram, então, normalizados pelo valor máximo, de modo a obter a intensidade da banda em relação à intensidade máxima (no início), em função do tempo de irradiação (convertido posteriormente para fluência de radiação UV). Os gráficos nas Figuras 58, 59 e 60 mostram os resultados desses cálculos para as amostras de clorofila a e $\beta$-caroteno.

Há uma clara diminuição na intensidade dos picos dos pigmentos em função da fluência da radiação síncrotron, e essa "taxa de degradação" dos picos varia com a adição de substratos inorgânicos na amostra. Comparando entre as amostras, é possível perceber que as intensidades do $\beta$-caroteno mostraram uma diminuição maior e mais rápida do que as intensidades das bandas da clorofila a, exceto para o solo simulado Lunar, confirmando a cinética de degradação mais rápida do carotenoide já observada anteriormente. 

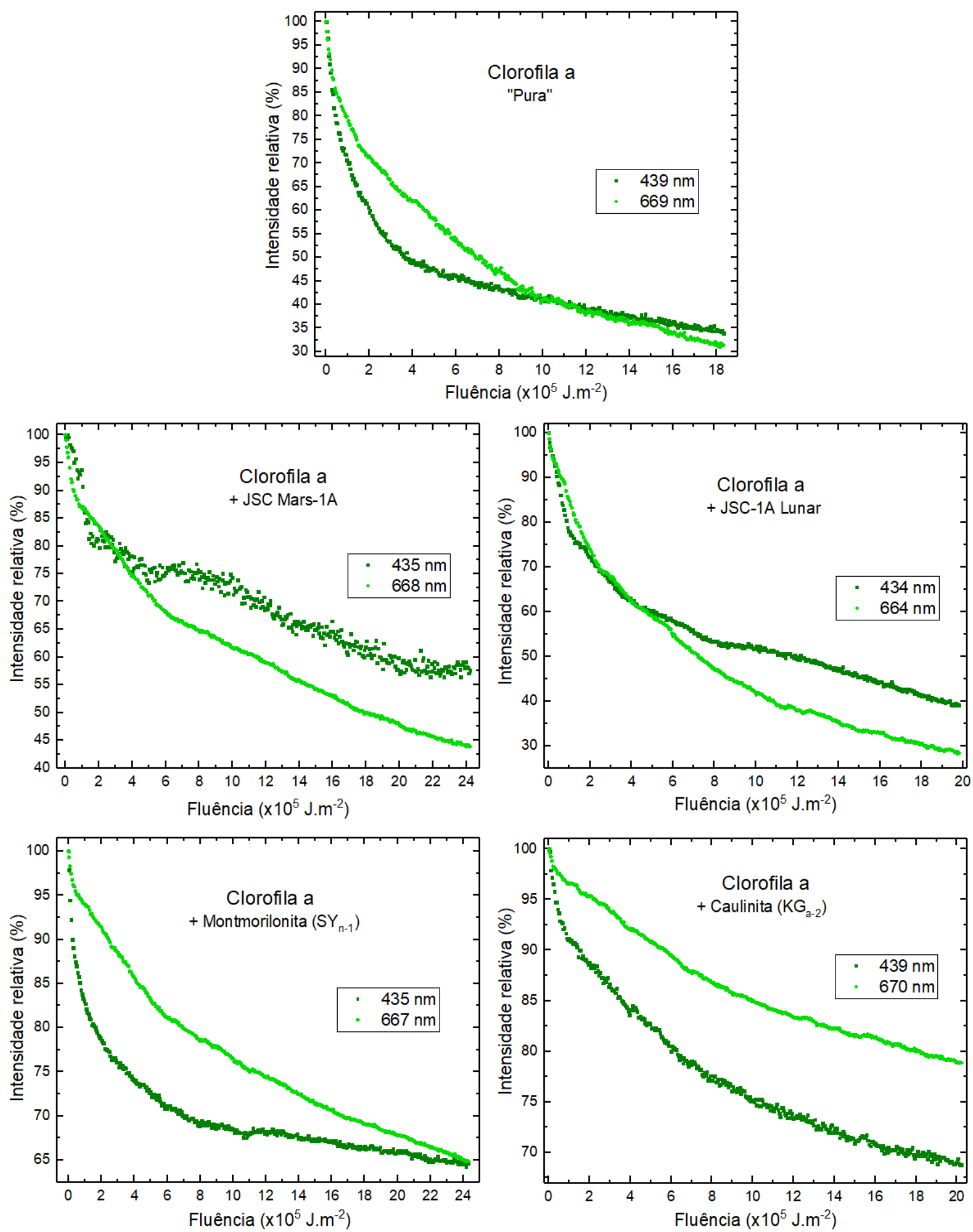

Figura 58 - Intensidade das bandas em $~ 435$ e $\sim 667 \mathrm{~nm}$ da clorofila a em relação à intensidade máxima, em função da fluência de radiação síncrotron.

Fonte: Elaborada pela autora 

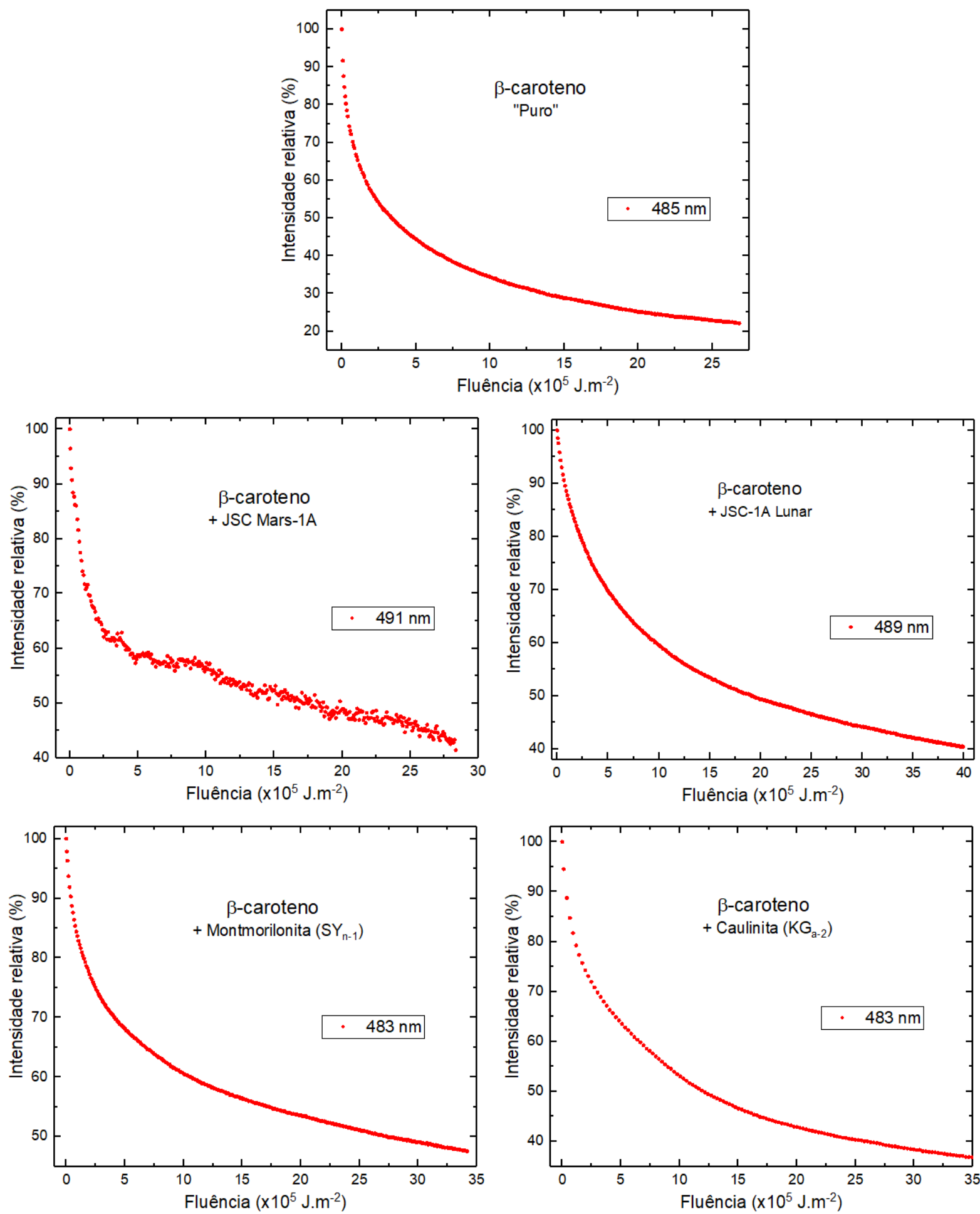

Figura 59 - Intensidade das bandas em $483 \mathrm{~nm}$ do $\beta$-caroteno em relação à intensidade máxima, em função da fluência de radiação síncrotron.

Fonte: Elaborada pela autora 

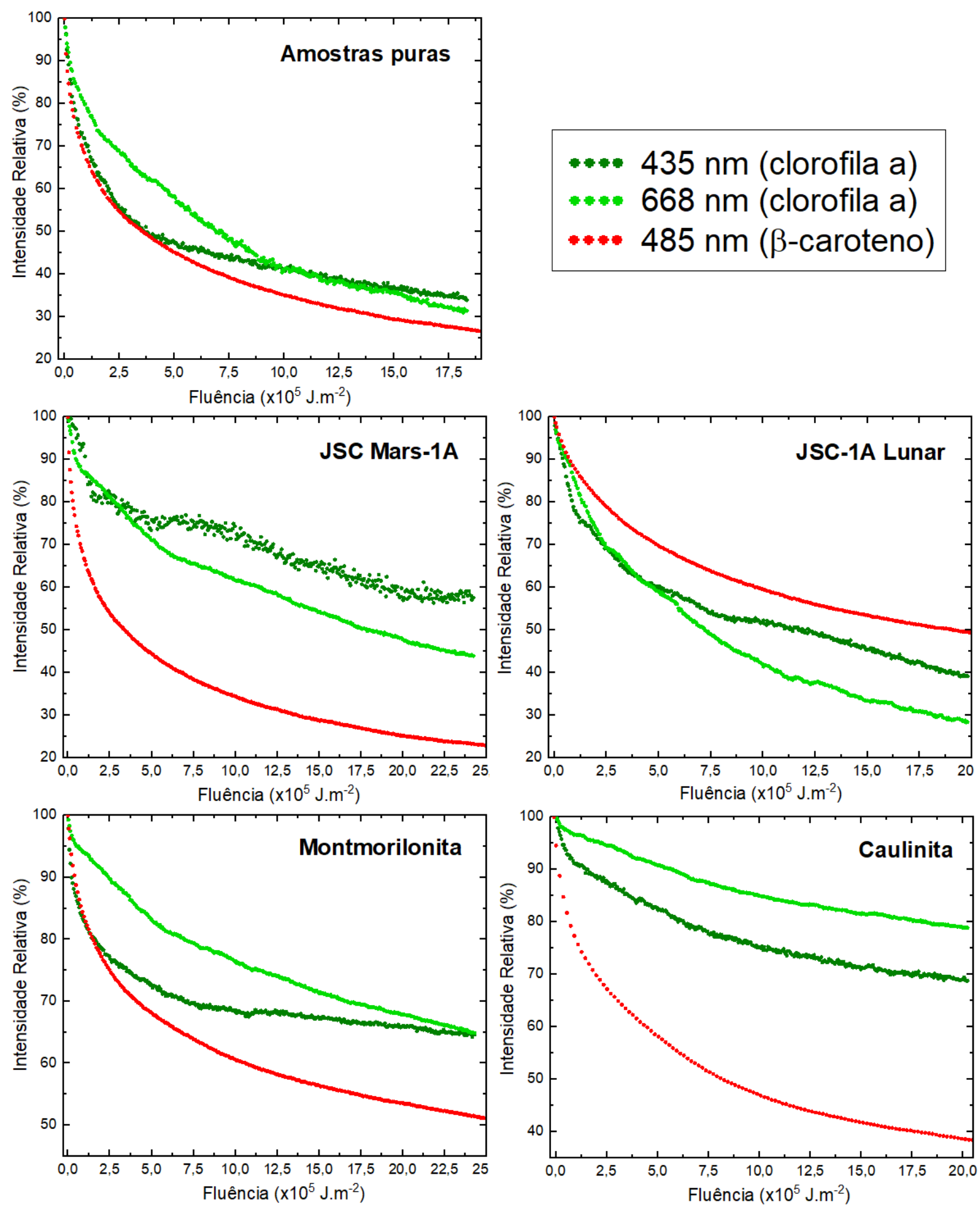

Figura 60 - Intensidade das bandas em $\sim 435$ e $\sim 667 \mathrm{~nm}$ da clorofila a e em $\sim 483 \mathrm{~nm}$ do $\beta$-caroteno em relação à intensidade máxima, em função da fluência de radiação síncrotron, com cada substrato. 
Uma forma de analisar e comparar as degradações das bandas seria fazendo um ajuste dos gráficos de intensidade em função da fluência e obtendo uma equação para a curva ajustada da qual poderíamos obter uma taxa de degradação, como feito nos experimentos anteriores. Porém, não foi possível ajustar uma curva exponencial para os gráficos completos, como pode-se observar no exemplo da Figura 61. Os dados são consistentes com uma exponencial de decaimento no início, mas logo divergem da curva exponencial, degradando mais lentamente do que o esperado.

Tal comportamento parece com o observado nos experimentos anteriores: o shielding effect causado pela camada de produtos depositada na superfície que provoca uma diminuição da taxa degradação das moléculas inferiores. E agora as amostras, além de não serem puras, estão misturadas com substratos inorgânicos, que também podem já estar causando um efeito protetor nas amostras desde o início das irradiações.

Os dados foram, então, divididos em 3 curvas para cada uma das quais foi possível ajustar uma curva exponencial, o que resulta em 3 regiões com taxas de degradação diferentes, como no exemplo da Figura 62. Ou seja, temos 3 "fases" diferentes de degradação das amostras.

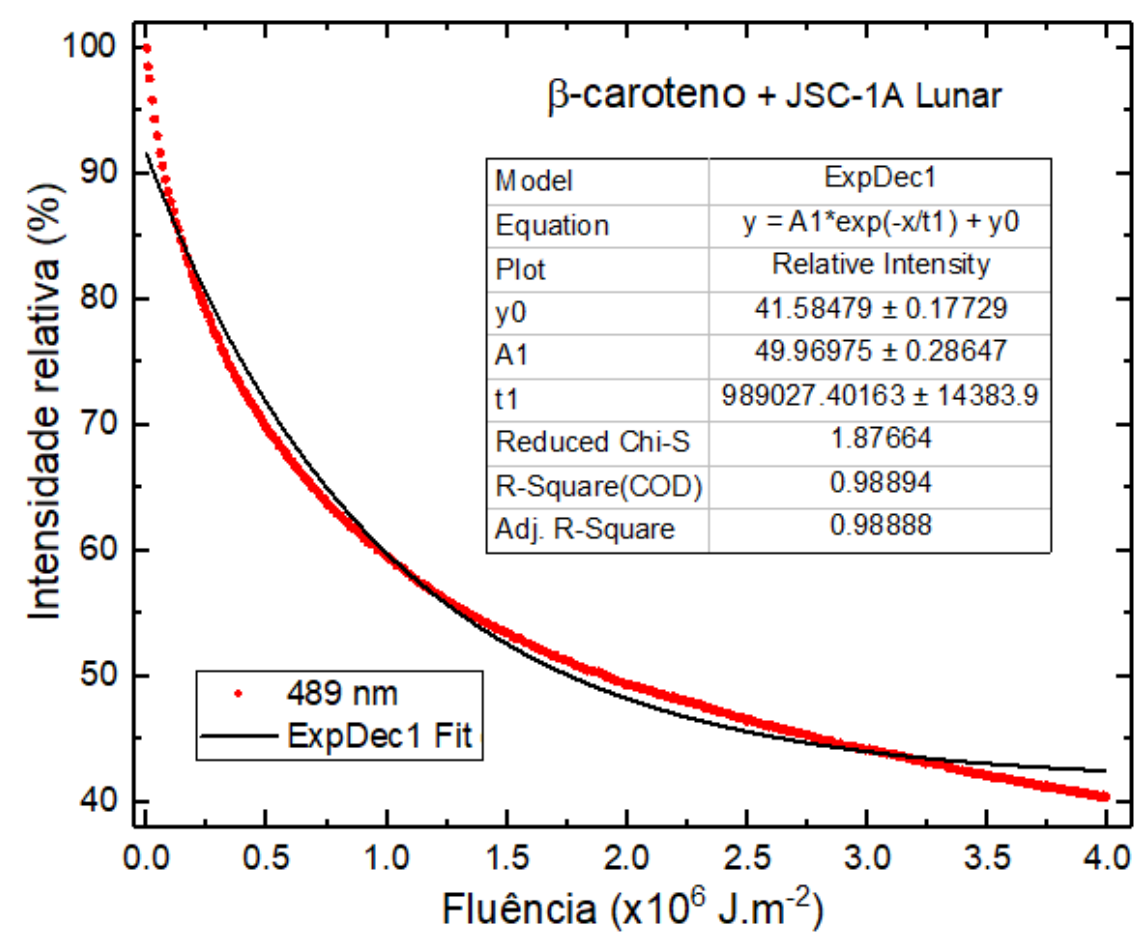

Figura 61 - Ajuste exponencial da curva de decaimento completa da amostra de $\beta$-caroteno com o solo lunar. Fonte: Elaborada pela autora 


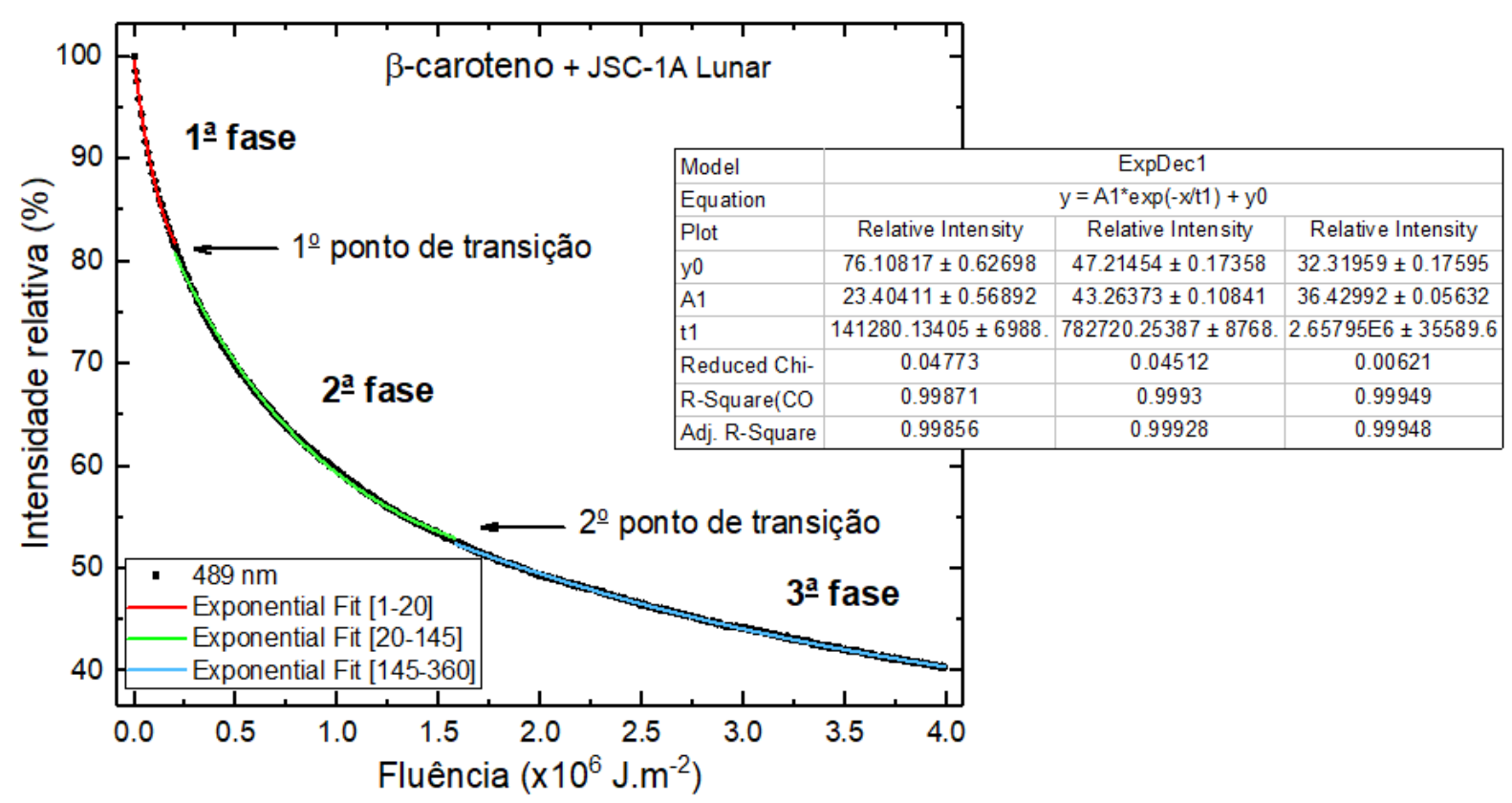

Figura 62 - Ajustes exponenciais das curvas de decaimento de 3 fases de degradação da amostra de $\beta$-caroteno com o solo lunar.

Fonte: Elaborada pela autora

Novamente, foi adotada a tendência da região onde o decaimento é mais lento ( $3^{\mathrm{a}}$ fase) e, assumindo que ela é constante, outro ajuste foi feito utilizando a equação exponencial simples. Foram calculadas as fluências necessárias para extinguir completamente as bandas dos pigmentos (1\% da intensidade inicial) em uma irradiação com luz UV.

Estes valores de fluência foram então cruzados com a irradiância na superfície de Marte, calculado na seção 4.2.3.2, de modo a calcular o tempo necessário para extinguir as bandas das amostras se elas estivessem presentes e expostas à radiação UV nessa superfície. Os resultados são mostrados na Figura 63.

Pode-se observar que as amostras puras são, em geral, mais degradadas do que as misturadas com substratos, exceto a banda em $437 \mathrm{~nm}$ da clorofila misturada com o solo lunar.

Em geral, as argilas caulinita e montmorilonita estão exercendo um papel protetor maior do que os solos simulados marciano e lunar. Como os solos são compostos basicamente de uma mistura de óxidos, eles podem estar auxiliando a degradação das amostras. 


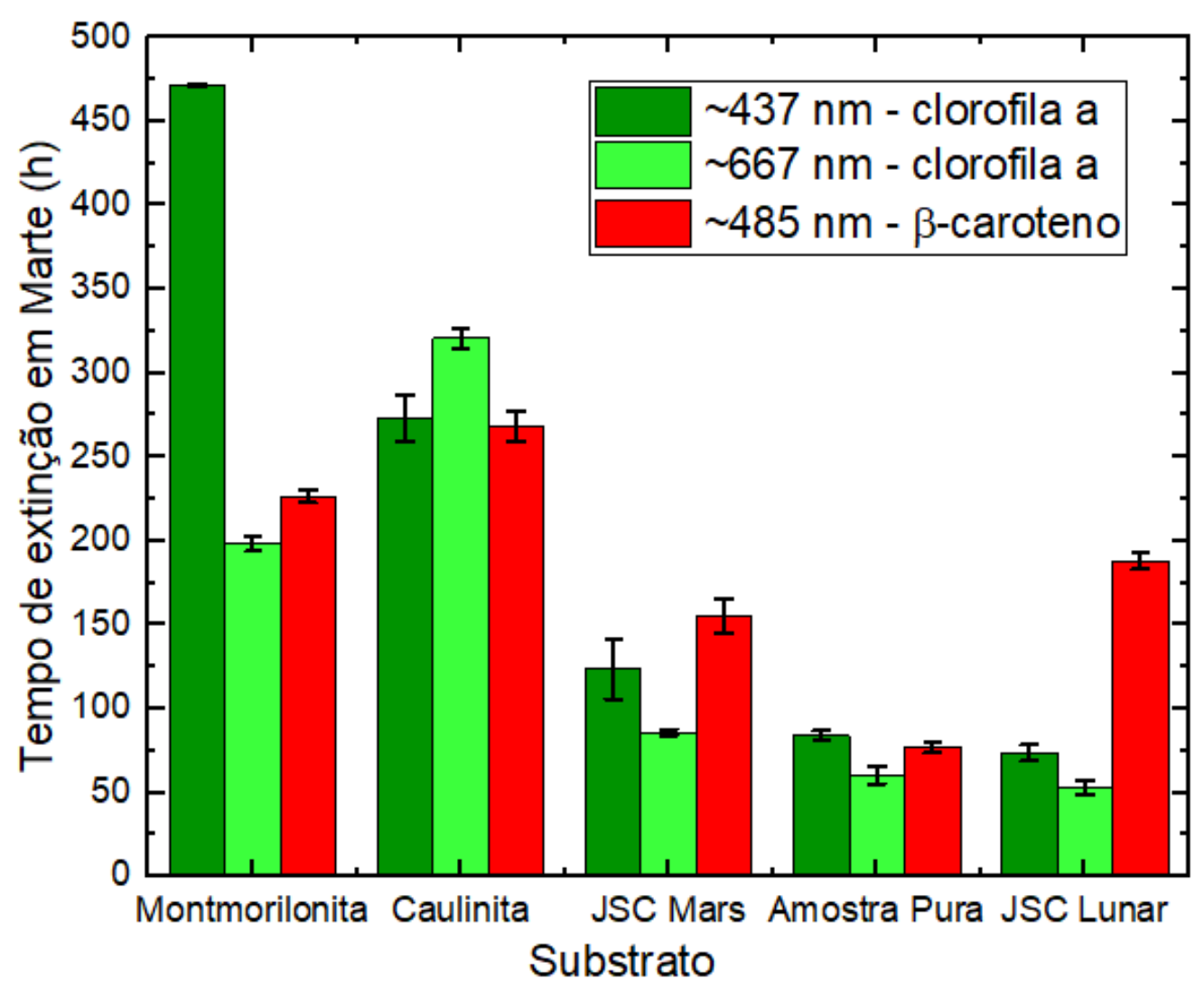

Figura 63 - Comparação entre os tempos necessários para extinguir as bandas em $\sim 430$ e $\sim 667$ nm da clorofila a e em $\sim 485 \mathrm{~nm}$ do $\beta$-caroteno, puras e com cada um dos substratos, expostas na superfície de Marte. Fonte: Elaborada pela autora

\subsubsection{Medida dos efeitos da irradiação por espalhamento Raman}

Um exemplo dos espectros Raman obtidos antes e após a irradiação é mostrado na Figura 64. Utilizando o próprio software do equipamento, WiRE 4.1 da Renishaw, foi obtida a média dos 30 espectros de cada amostra, foram subtraídas as linhas de base e os espectros resultantes foram normalizados pela intensidade do pico do pó de diamante em $\sim 1333 \mathrm{~cm}^{-1}$. 


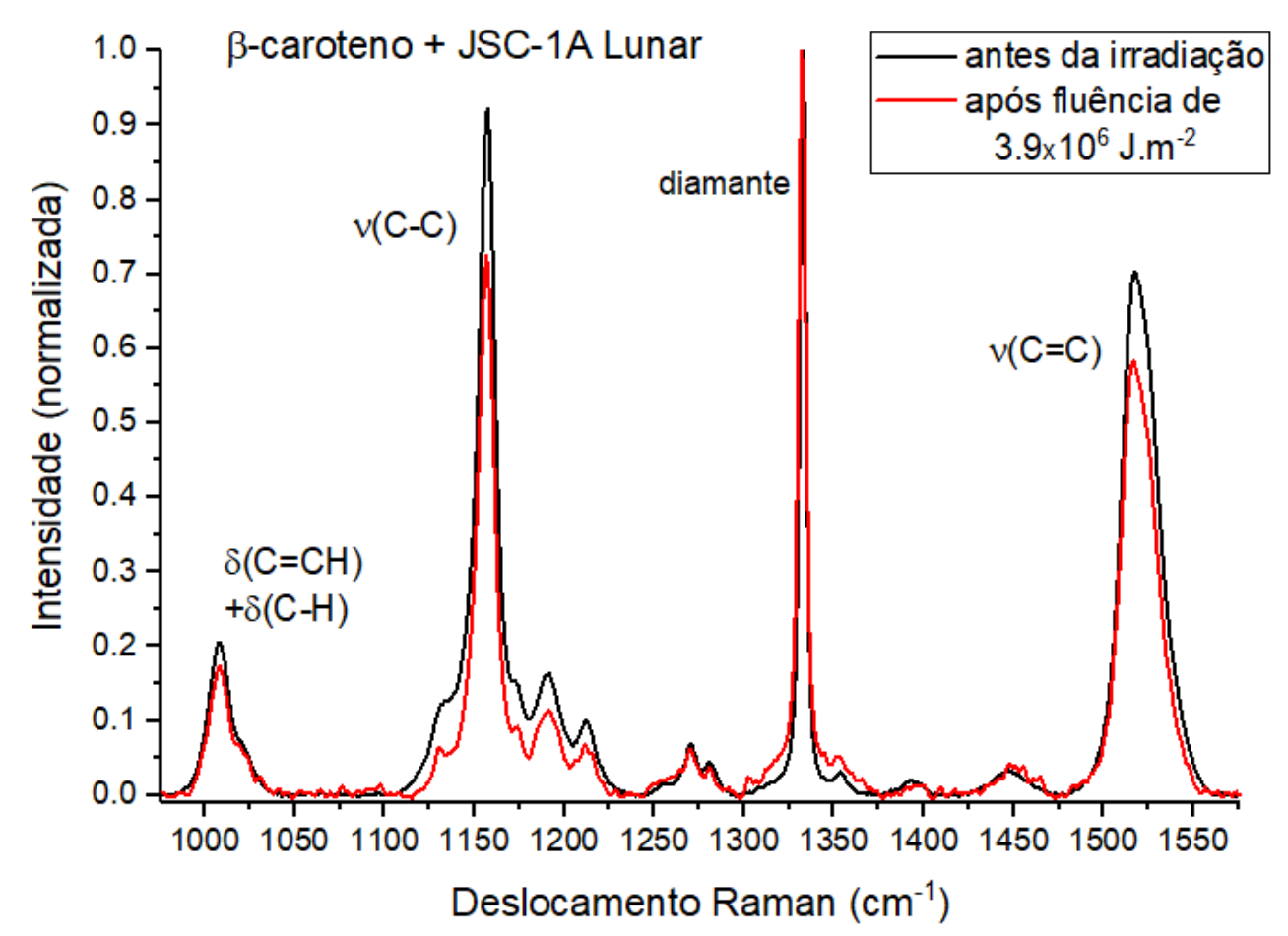

Figura 64 - Espectros Raman obtidos antes e após a irradiação de 1 hora da amostra de $\beta$-caroteno com o solo lunar.

Fonte: Elaborada pela autora

\subsubsection{Análise dos limites de detecção - espectros Raman}

Os limites de detecção das amostras de $\beta$-caroteno por espectroscopia Raman também foram baseados na diminuição da intensidade dos picos em função da fluência de radiação.

De modo a comparar os picos estatisticamente, foram feitos ajustes das curvas de interesse para todas as replicatas e calculadas as intensidades dos picos, utilizando a ferramenta Mapping review no software WiRE 4.1. Utilizando, então, o software Origin 9.1, foram obtidas as médias das intensidades e os desvios padrão para cada pico. A Figura 65 mostra as intensidades dos picos do $\beta$-caroteno em função da fluência de radiação síncrotron recebida, para cada mistura.

Assim como observado para os espectros UV-Vis, pode-se observar também uma diminuição na intensidade dos picos Raman do $\beta$-caroteno em função da fluência da radiação síncrotron, o que pode confirmar que o clareamento no ponto de irradiação na pastilha está relacionado a uma quebra do sistema conjugado das moléculas de $\beta$-caroteno. Porém, a degradação dos picos Raman é muito menor que a degradação das bandas no UV-Vis, para a mesma amostra.

No geral, a amostra com as três ligações mais bem preservadas foi a de $\beta$-caroteno misturada com o solo Lunar. Porém, cada um dos picos teve um comportamento de degradação distinto entre as amostras. 
A quebra do sistema conjugado das moléculas de $\beta$-caroteno é melhor evidenciada pela diminuição no pico em $1520 \mathrm{~cm}^{-1}$, correspondente ao estiramento das ligações $\mathrm{C}=\mathrm{C}$. Pode-se observar que a amostra misturada com caulinita teve a menor degradação das ligações $\mathrm{C}=\mathrm{C}$, seguida das amostras com o solo lunar, o solo marciano, a montmorilonita e, por fim, a amostra pura teve a maior degradação das ligações $\mathrm{C}=\mathrm{C}$ na média - sendo que as 3 ultimas não podem ser totalmente distintas, devido às suas barras de erros.

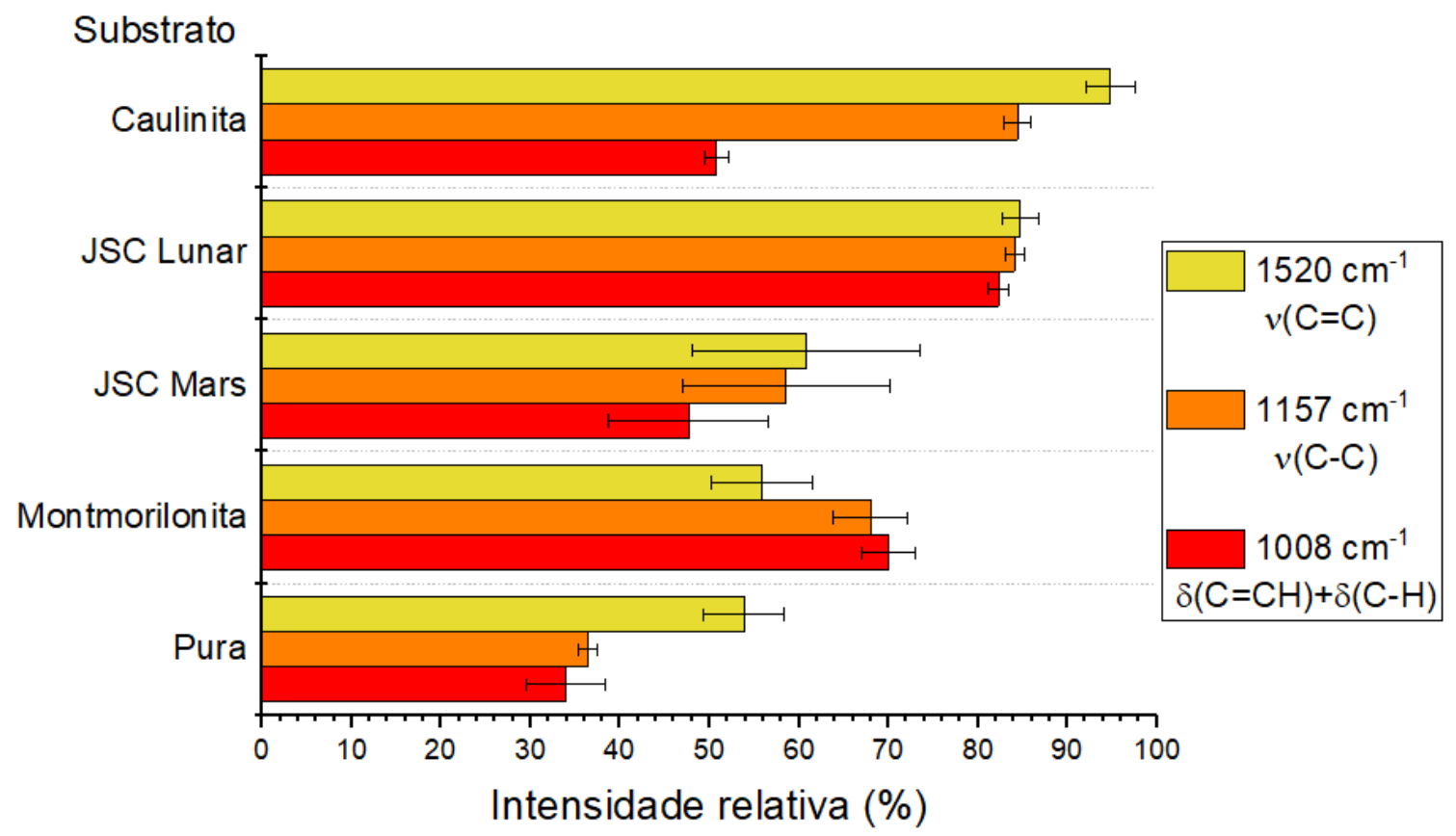

Figura 65 - Intensidades dos picos do $\beta$-caroteno em função da fluência de radiação síncrotron. Fonte: Elaborada pela autora

\subsection{EXPERIMENTOS NA ESTRATOSFERA: balões de alta-altitude}

\subsubsection{Garatéa I}

A resiliência dos microrganismos foi analisada pelo grupo de pesquisa do Laboratório Quimiosfera, e as análises das biomoléculas foram conduzidas utilizando espectroscopia Raman, com laser de excitação de $785 \mathrm{~nm}$. Os resultados dos pigmentos extraídos da $D$. radiodurans e do $\beta$-caroteno, ambos depositados em alumínio, são mostrados nas Figura 66 e Figura 67. Cada figura apresenta a comparação entre os espectros das amostras nas 3 condições experimentais: a que voou no balão e foi exposta à radiação (Exposto), a que voou no balão e não foi exposta à radiação (Não Exposto), e o controle mantido no escuro em terra (Controle). 


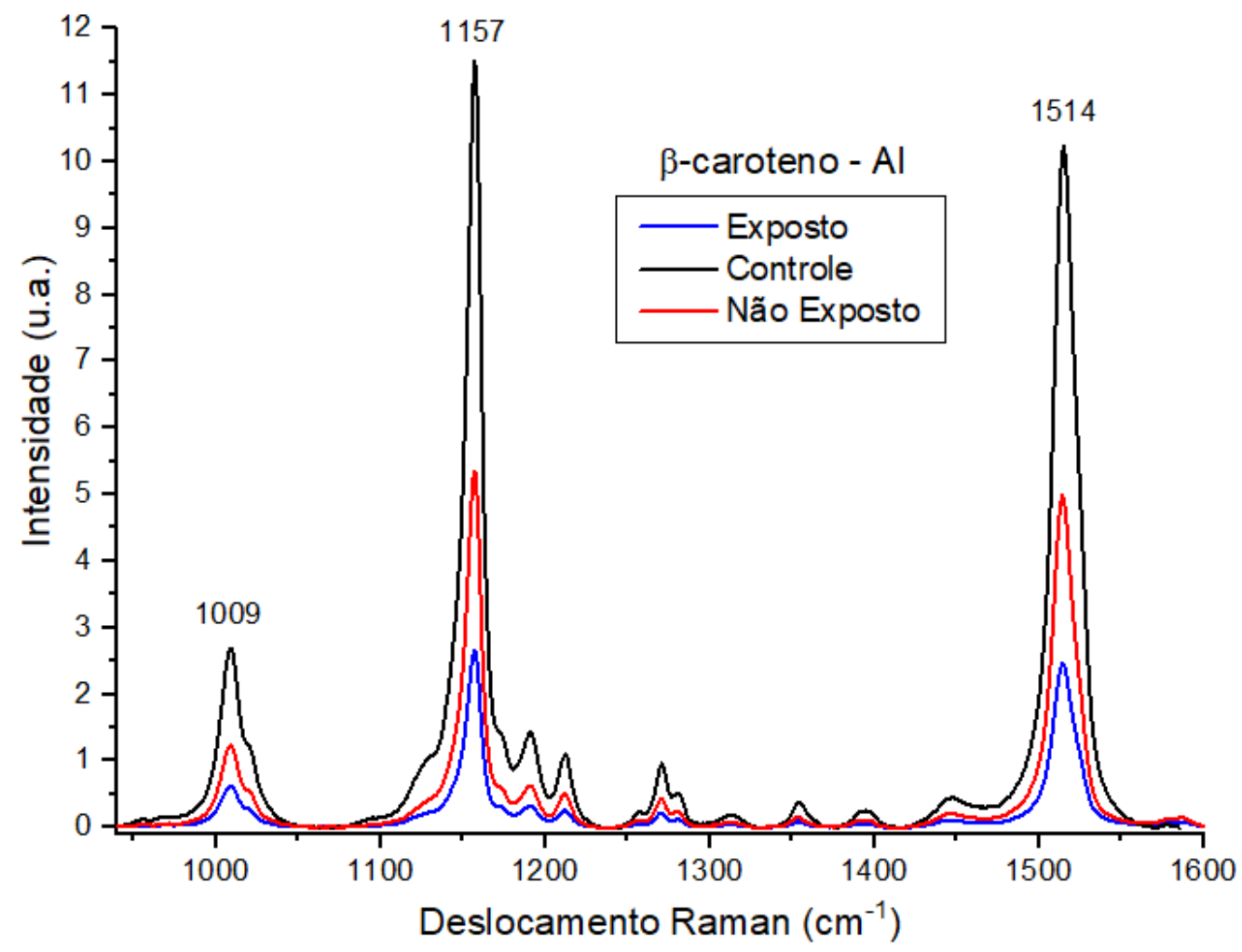

Figura 66 - Espectro Raman de $\beta$-caroteno nas 3 condições experimentais: exposta à radiação, não exposta à radiação e controle em Terra. As curvas não estão normalizadas.

Fonte: Elaborada pela autora

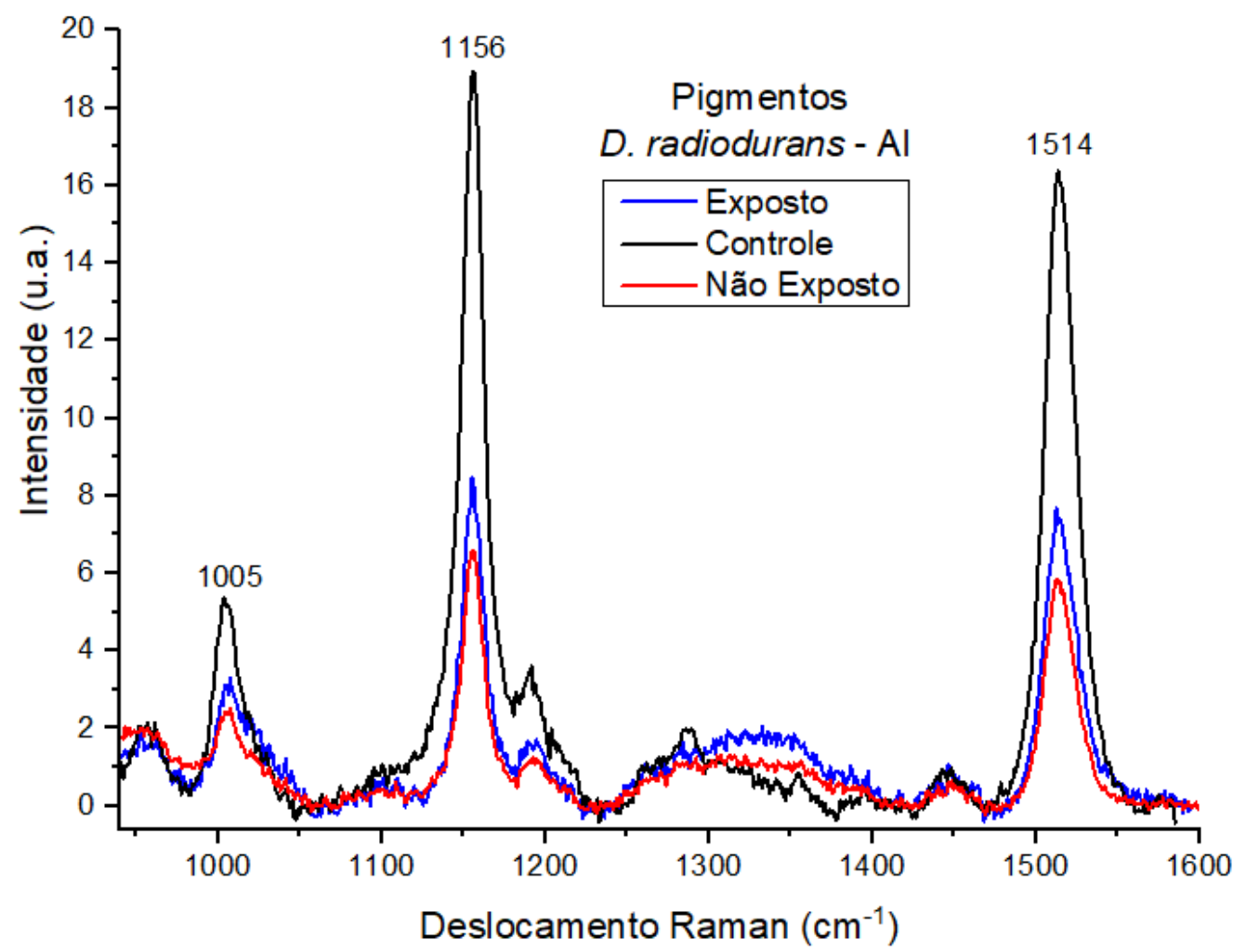

Figura 67 - Espectro Raman dos pigmentos extraídos da D. radiodurans nas 3 condições experimentais: exposta à radiação, não exposta à radiação e controle em Terra. As curvas não estão normalizadas.

Fonte: Elaborada pela autora 
Os espectros mostrados são uma média de replicatas e de 9 micro-regiões de medidas realizadas por amostra, utilizando o software Origin 9.1. Pode-se observar que em ambas as amostras há 3 picos característicos praticamente nas mesmas posições, porque ambas as amostras são carotenoides. Como já mencionado, o pigmento mais abundante da $D$. radiodurans é a deinoxantina.

Os espectros das amostras expostas, não-expostas e controle são qualitativamente iguais, com os picos na mesma posição, sem surgimento ou desaparecimento de picos. Isso indica que não houve grandes mudanças estruturais na molécula. A diferença de intensidade entre os espectros não deve ser interpretada como um sinal da degradação das moléculas, visto que a intensidade Raman é fortemente dependente das condições da amostra, espessura, espalhamento, etc.

Neste primeiro lançamento a sonda Garatéa provou ser uma plataforma confiável de pesquisa do ambiente estratosférico, e este primeiro experimento em balão foi importante para o aperfeiçoamento dos próximos experimentos.

Um relatório descrevendo todo o experimento e os resultados foi elaborado e enviado à comissão julgadora, e nos rendeu $2^{\circ}$ lugar na categoria de Melhor Experimento do GSBC 2016. O prêmio foi um novo balão e um paraquedas que foram utilizados no próximo lançamento elaborado pelo grupo Zenith.

\subsubsection{Garatéa II}

\subsubsection{Medida dos efeitos da irradiação por espalhamento Raman}

A resiliência dos microrganismos novamente foi analisada pelo grupo de pesquisa do Laboratório Quimiosfera, e as análises das biomoléculas foram conduzidas utilizando espectroscopia Raman, com laser de excitação de 785 nm. Foram obtidos 10 espectros por replicata em micro-regiões diferentes de cada amostra, utilizando uma lente "macro $30 \mathrm{~mm}$ ".

Utilizando o software WiRE 4.1 da Renishaw, foi obtida a média de todos os espectros, subtraídas as linhas de base e os espectros resultantes foram normalizados pela intensidade do pico do pó de diamante em $\sim 1333 \mathrm{~cm}^{-1}$, para cada amostra em cada uma das 3 condições experimentais (E, $\mathrm{N}$ e $\mathrm{C}$ ). Alguns dos espectros mais interessantes são mostrados nas figuras abaixo. O restante dos espectros é mostrado no Apêndice.

Algumas das amostras, como a guanina, fulereno, hemina, ATP e ácido fumárico (espectros no Apêndice), não apresentaram nenhuma variação significante nas posições dos picos ou em 
suas intensidades. Isso pode ser explicado pela curta duração do voo do balão na estratosfera, não sendo suficiente para causar alterações nas moléculas. Ou elas podem ser exemplos de biomoléculas resistentes às condições da estratosfera e, consequentemente, na superfície de Marte. Voos de mais longa duração seriam necessários para confirmar.

Já os espectros da Figura 68, mostram que algumas mudanças ocorreram com o aminoácido DL-cisteína ao sofrer as condições da estratosfera. Enquanto o pico do diamante permanece inalterado, a intensidade da maioria dos picos da amostra variou. No detalhe do gráfico, o pico em $499 \mathrm{~cm}^{-1}$ correspondente à ponte dissulfeto tem maior intensidade na amostra que voou e foi exposta à radiação, e menor intensidade na amostra que voou e não foi exposta à radiação, ambas em comparação ao controle. A presença desse pico na amostra controle já é uma indicação de que somente a adição de água já fez com que dímeros do aminoácido (cistina) fossem formados, já que a cisteína não possui tal ligação. Então, seguindo o mesmo raciocínio utilizado para os experimentos em laboratório, este aumento na intensidade do pico pode indicar que, em comparação com o controle, houve a formação de um maior número de ligações dissulfídicas com a exposição à radiação, e uma formação de um menor número de ligações com as condições estratosféricas e sem exposição solar.

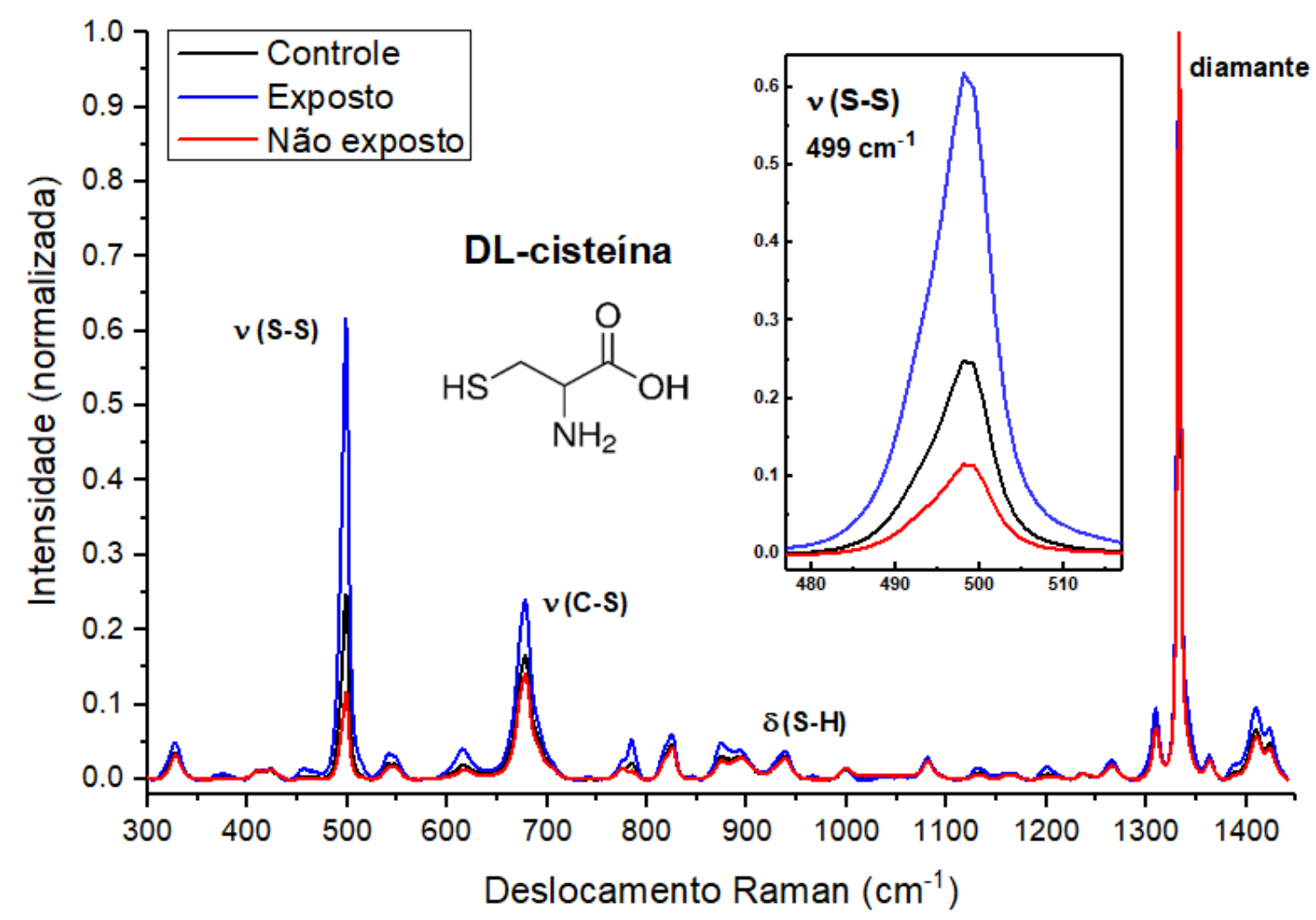

Figura 68 - Espectros Raman da DL-cisteína nas 3 condições experimentais: exposta à radiação, não exposta à radiação e controle em Terra.

Fonte: Elaborada pela autora 
Para outras amostras, foram observadas diminuições nas intensidades dos picos, como por exemplo os mesmos carotenoides enviados na Garatéa I: os espectros das amostras de $\beta$ caroteno e da bactéria Deinoccocus radiodurans são mostrados na Figura 69.
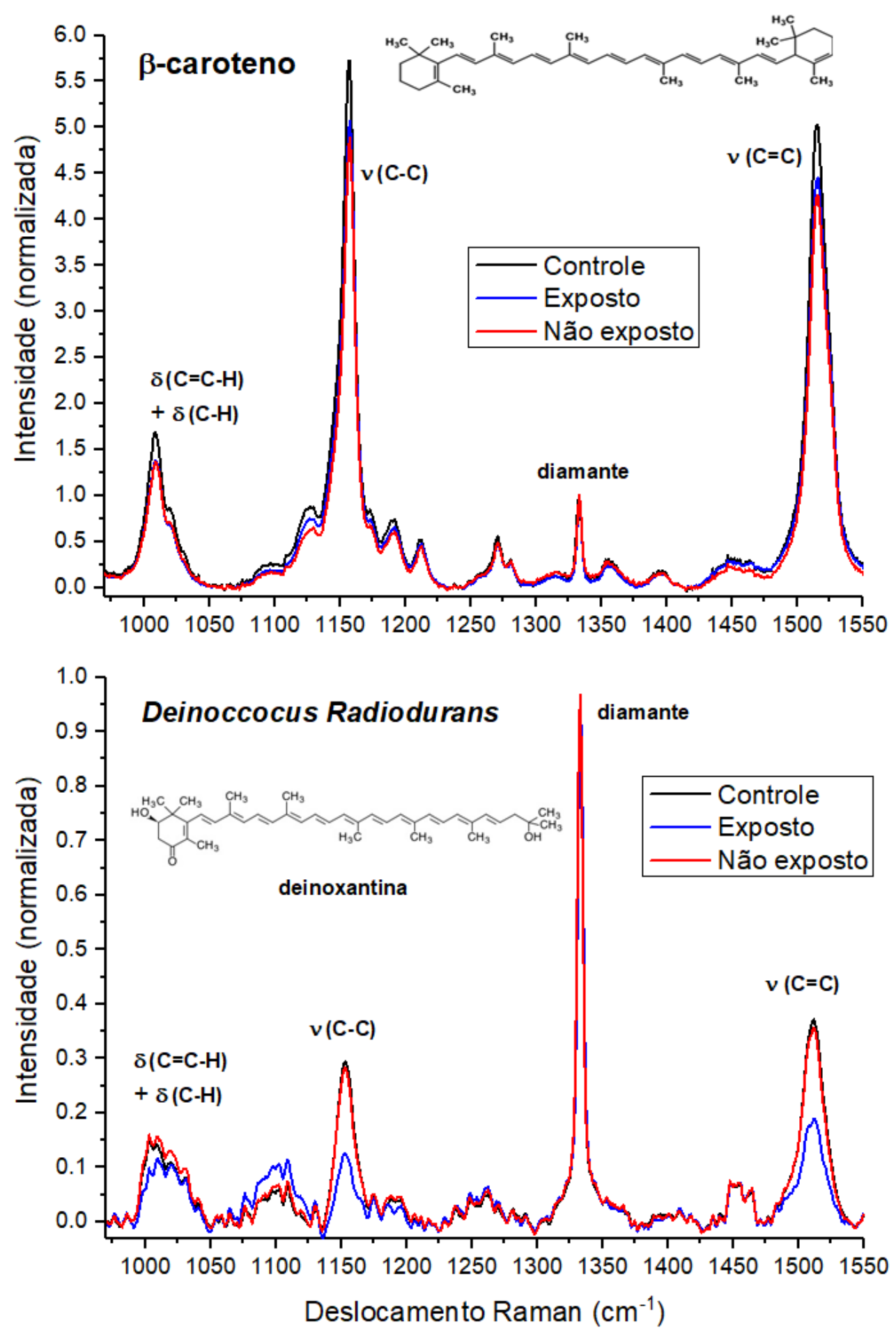

Figura 69 - Espectros Raman do $\beta$-caroteno e da bactéria Deinoccocus radiodurans nas 3 condições experimentais: exposta à radiação $(\mathrm{E})$, não exposta à radiação $(\mathrm{N})$ e controle em Terra $(\mathrm{C})$.

Fonte: Elaborada pela autora 
Podemos observar novamente que em ambos os espectros os picos relacionados aos carotenoides permanecem qualitativamente inalterados com o voo, mas sofreram uma diminuição de intensidade, as quais podem ser agora calculadas a partir da normalização com o pico do diamante (padrão interno).

\subsubsection{Análise dos limites de detecção das amostras pelos espectros Raman}

Como não foi possível medir as fluências de radiação UV durante o voo do balão, as comparações foram feitas utilizando as intensidades e as áreas dos picos de interesse das amostras. Os cálculos foram feitos da mesma maneira anteriormente descrita na seção 4.2.3.6 para o $\beta$-caroteno.

A Figura 70 mostra uma comparação entre algumas das amostras que apresentaram a ligação dissulfídica (o aminoácido cisteína puro e com substratos, e o dímero cistina puro). E as Figuras 71 e 72 mostram comparações entre os três picos dos carotenoides ( $\beta$-caroteno e deinoxantina da bactéria).

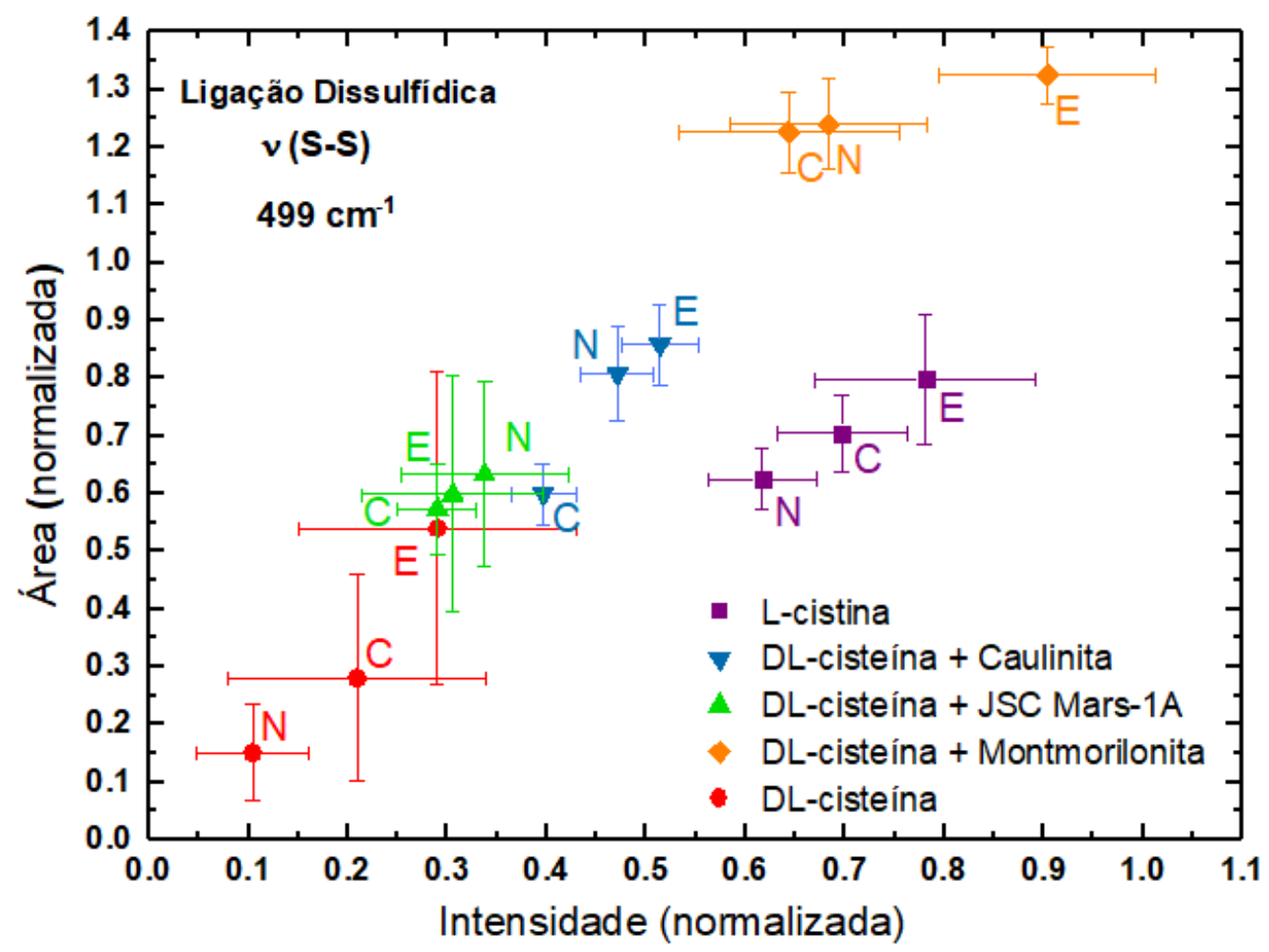

Figura 70 - Área por intensidade dos picos da ponte dissulfeto em diferentes amostras. Fonte: Elaborada pela autora 


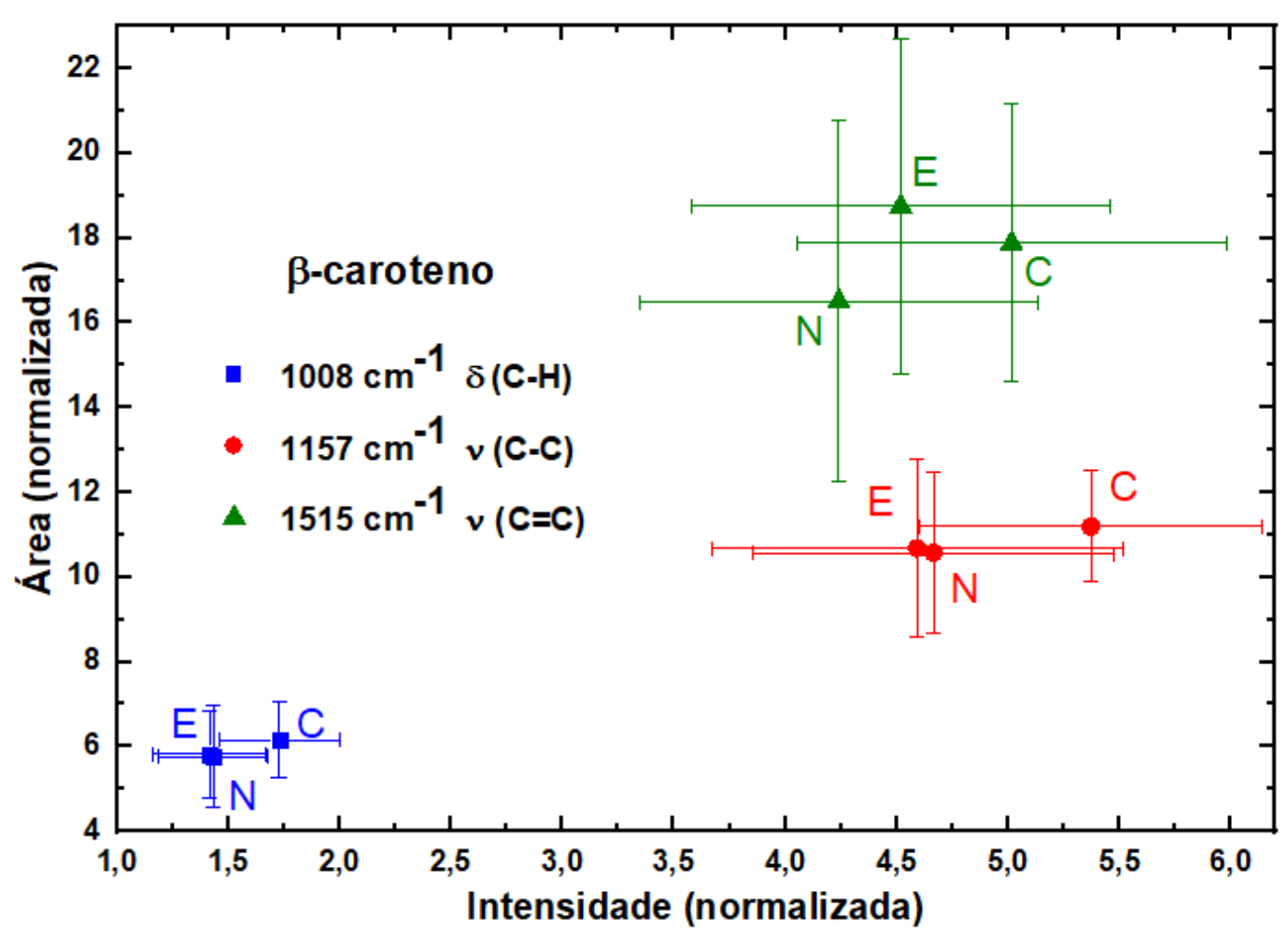

Figura 71 - Área por intensidade dos picos do $\beta$-caroteno.

Fonte: Elaborada pela autora

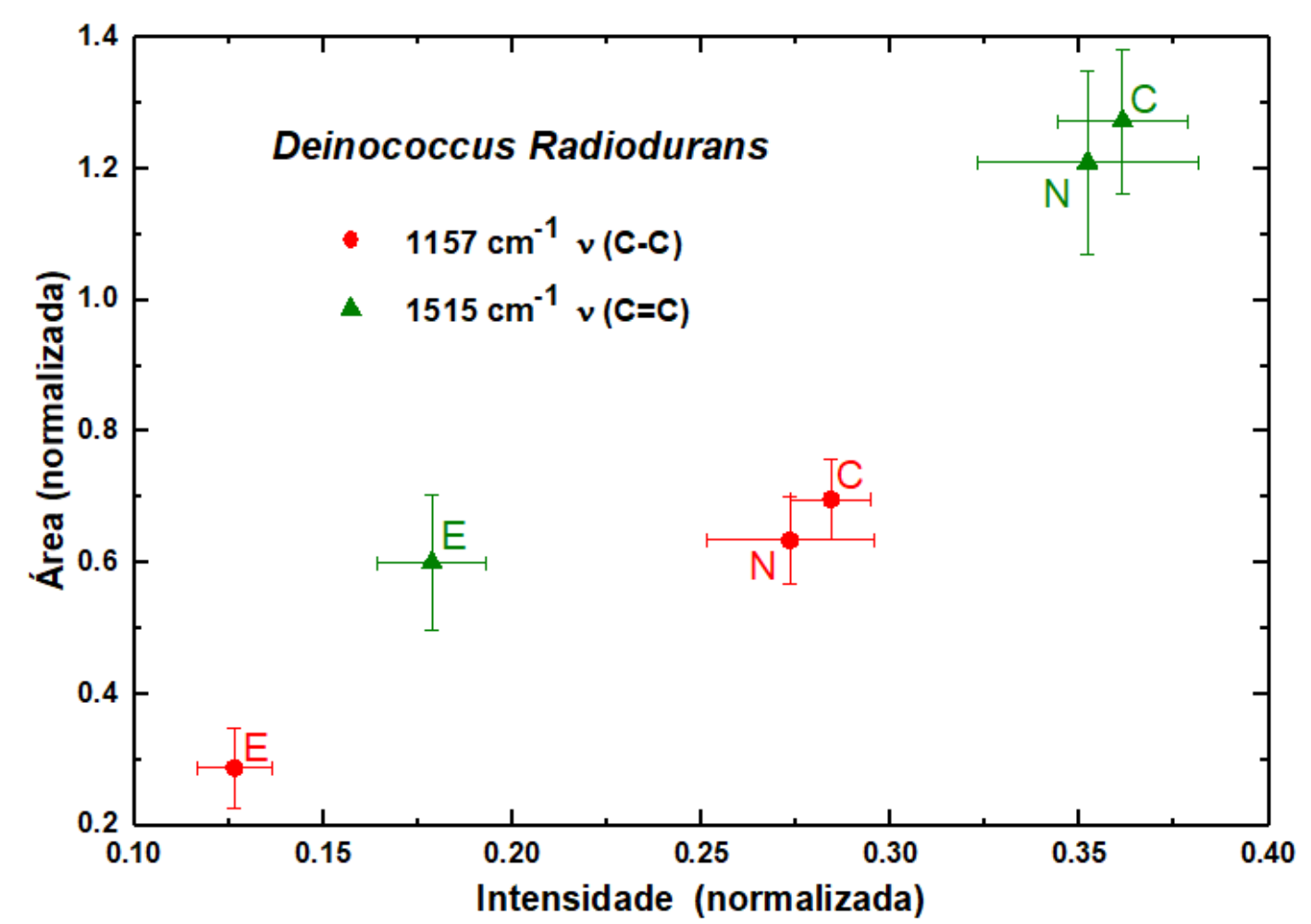

Figura 72 - Área por intensidade dos picos do carotenoide presente na bactéria Deinoccocus Radiodurans. Fonte: Elaborada pela autora 
As grandes barras de erro podem indicar que o número de espectros obtidos ainda foi insuficiente para uma boa análise estatística, ou simplesmente que as amostras apresentavam uma variabilidade intrínseca.

Apesar disso, foi possível observar com estes resultados comportamentos distintos do mesmo pico para cada amostra.

Os substratos inorgânicos alteram de maneiras diferentes a facilidade da formação da ponte dissulfeto. No geral, a amostra exposta apresenta uma maior intensidade e área do que as amostras controle e não exposta, indicando que a radiação solar provocou a formação de um maior número de ligações dissulfídicas. Porém, as barras de erro não permitem uma conclusão concreta desses resultados.

Os picos nas amostras de $\beta$-caroteno que voaram no balão (exposta e não exposta) apresentaram, no geral, uma menor intensidade que na amostra controle, mas também não são completamente conclusivos devido às barras de erro. Já os picos do carotenoide da bactéria que foi exposta à radiação solar apresentaram intensidades e áreas claramente separadas das amostras que não foram expostas.

O ambiente celular da bactéria pode ter facilitado a quebra do carotenoide, em comparação com o carotenoide puro. Mas o próprio carotenoide deinoxantina é mais susceptível à quebra radiolítica do que o $\beta$-caroteno. Tal conclusão já foi reportada em experimentos que compararam a diminuição das intensidades dos picos Raman dos dois carotenoides após irradiação ionizante (102). Essa maior susceptibilidade à quebra foi atribuída à cadeia carbônica mais longa, à presença de apenas um anel terminal e à presença de grupos oxigenados (carbonila e hidroxila) terminais. E isso está intimamente relacionado ao fato de que a deinoxantina é um melhor antioxidante, pois tem maior capacidade sequestrante de ROS (Espécies Reativas de Oxigênio), que são formadas pela irradiação da água. Acredita-se que essa proteção "sacrificante" está intimamente ligada à grande resiliência da bactéria $D$. radiodurans contra irradiação ionizante. (10)

Portanto, as assinaturas espectroscópicas Raman do $\beta$-caroteno se mostraram mais fotoestáveis do que as da deinoxantina em um ambiente de "Marte úmido". 


\section{CONCLUSÕES}

A detectabilidade de potenciais bioassinaturas moleculares e a fotoestabilidade de suas assinaturas espectroscópicas foram estudadas em ambientes extraterrestres simulados utilizando câmaras de simulação e irradiações com luz ultravioleta. As biomoléculas-modelo selecionadas apresentaram respostas que permitiram sua detecção e caracterização pelos métodos espectroscópicos utilizados, tanto com medidas in situ (reflectância no UV-Vis) quanto com medidas ex situ de bancada (Raman, transmissão no IR e no UV-Vis).

Deve-se lembrar que, como os experimentos foram elaborados com a intenção de representar amostras de biomoléculas reais em ambientes astrofísicos reais, as amostras não foram irradiadas na sua forma pura e em filmes opticamente finos e, portanto, não foram feitas análises de fotoestabilidade comuns, referentes à fotodegradação das amostras em si. Os estudos foram realizados, na verdade, com a intenção de avaliar a fotoestabilidade das assinaturas espectroscópicas das amostras obtidas por cada técnica. Tal estudo foi feito de acordo com as variações nas intensidades de bandas/picos presentes nos espectros das amostras em função da fluência da radiação, que foram atribuídas a quebras ou formações de ligações. Tal método possibilitou um estudo sobre o limite de detecção de potenciais bioassinaturas em ambientes extraterrestres, como a superfície de Marte e da Lua, utilizando diferentes técnicas espectroscópicas.

A espectroscopia por absorção no UV-Vis (por transmissão ou reflectância) se mostrou uma técnica eficiente para monitorar quantitativamente as bandas eletrônicas das amostras in situ e em tempo real. A não necessidade de preparo complexo das amostras torna a espectroscopia por reflectância uma técnica adequada para medidas in situ. As rápidas diminuições nas intensidades das bandas UV-Vis, porém, indicam que os pigmentos escolhidos são pouco fotoestáveis para detecção com esta técnica nos ambientes simulados, mesmo com leve proteção de substratos inorgânicos. Essas biomoléculas só seriam detectadas por tal técnica se estiverem presentes em grande abundancia no planeta analisado, podendo ser detectadas até mesmo remotamente (assim como os pigmentos da vegetação Terrestre), ou se estiverem protegidas por uma camada de substrato inorgânico, que tem a capacidade de barrar a radiação UV e proteger as amostras. Entretanto, apesar de não ser a técnica ideal para detecção dessas potenciais bioassinaturas em superfícies planetárias, ela se mostrou eficiente para a realização de experimentos com medidas in situ em laboratório, podendo ser utilizada também para experimentos de exposição em missões espaciais, como em balões estratosféricos e em CubeSats. 
A espectroscopia por espalhamento Raman, apesar de não ter fornecido dados quantitativos estatisticamente confiáveis sobre a degradação das assinaturas das amostras, se mostrou uma técnica ideal para a análise qualitativa da integridade das ligações interatômicas nas moléculas após as irradiações. As amostras mostraram pouca ou quase nenhuma variação no espectro Raman durante as irradiações, confirmando uma grande fotoestabilidade para sua detecção com esta técnica. Portanto, foi confirmado o grande potencial da técnica Raman para a detecção e caracterização in situ de bioassinaturas moleculares em ambientes extraterrestres, mesmo após grandes fluências de radiação solar.

E a espectroscopia no infravermelho (médio) também se mostrou uma técnica eficiente para a análise qualitativa da integridade das ligações nas moléculas durante as irradiações com radiação UVC. Foi confirmada a vantagem desta técnica para estudos fotoquímicos, por fornecer picos característicos das principais funções orgânicas, sendo, portanto, mais informativo para análise de compostos orgânicos. Foi observada pouca variação nos espectros IR durante as irradiações, a partir dos quais ainda era possível identificar as amostras, o que pode ser uma confirmação de uma grande fotoestabilidade para detecção com esta técnica.

Às quebras de ligações foi associada uma "taxa de extinção" das bandas, que variou com a mistura de diferentes substratos inorgânicos na amostra, o que pode indicar um efeito de proteção contra a degradação das biomoléculas por conta dos substratos (diretamente relacionados a materiais encontrados em superfícies planetárias, meteoritos e asteroides).

As amostras de pigmentos biológicos puras foram irradiadas com luz UVC e analisadas por transmissão no UV-Vis. Ajustes exponenciais e polinomiais foram feitos para tentar inferir quanto tempo a mais de irradiação UVC seria necessário para extinguir as bandas das amostras e, assim, fazer uma primeira comparação entre elas. Apesar dos resultados dos cálculos que indicam que a banda do $\beta$-caroteno demoraria mais para ser extinta (chegar a $1 \%$ da intensidade inicial) do que as de clorofila a, é possível perceber nos espectros que a diminuição da intensidade da banda do $\beta$-caroteno foi consideravelmente mais rápida do que a das duas bandas da clorofila a. Em 45 minutos de irradiação a banda do $\beta$-caroteno chega em $\sim 20 \%$ da intensidade inicial, sendo já dificilmente identificadas, enquanto que as da clorofila a ainda estão com 80 a 95\%. Portanto, em concordância também com a descoloração mais rápida dos filmes, a assinatura espectroscópica no UV-Vis do $\beta$-caroteno parece ser menos fotoestável do que as assinaturas da clorofila a, após uma irradiação com luz UVC.

O experimento de simulação ambiental na AstroCam forneceu dados sobre a sobrevivência de uma assinatura da amostra de $\beta$-caroteno na superfície de Marte. Foram simuladas as condições ambientais marcianas e a amostra foi monitorada por reflectância in situ no UV-Vis. 
O perfil da degradação confirmou a hipótese de que as moléculas de $\beta$-caroteno têm uma cinética rápida quando irradiadas, e tendem a formar uma camada protetora que diminui ou até impede a degradação das moléculas inferiores (o shielding effect). Foi calculado que suas bandas espectroscópicas no UV-Vis demorariam de 175 a 510 horas para serem extintas se essa amostra estivesse presente e sendo irradiada na superfície de Marte.

Os experimentos na TGM com radiação síncrotron foram realizados para comparar os efeitos dos diferentes substratos inorgânicos que podem estar presentes nas superfícies extraterrestres associados às bioassinaturas. Foram calculados os tempos necessários para extinguir as bandas de absorção no UV-Vis das amostras de $\beta$-caroteno e clorofila a se elas estivessem presentes e expostas à radiação UV na superfície de Marte. Em geral, as amostras puras foram mais degradadas e as argilas caulinita e montmorilonita exerceram um papel protetor maior do que os solos simulados marciano e lunar. Também foi analisada uma diminuição da detectabilidade dos picos Raman do $\beta$-caroteno após a fluência total do experimento ( $19 \mathrm{~h}$ na superfície de Marte sem nenhuma proteção). Novamente a amostra pura sofreu maior degradação e a argila caulinita ofereceu maior proteção. Portanto, as regiões deposicionais que contém argilas em Marte, por exemplo, como as crateras mencionadas anteriormente, seriam mais promissoras para a aplicação desta técnica espectroscópica, do que as outras regiões com solos compostos basicamente de uma mistura de óxidos, os quais podem talvez auxiliar a degradação das amostras.

Os resultados obtidos nas missões Garatéa I e II provaram que sondas a bordo de balões de alta-altitude são plataformas confiáveis de pesquisa em astrobiologia no ambiente estratosférico, além de serem extremamente úteis para a validação dos instrumentos que serão posteriormente utilizados em missões espaciais. Os resultados dos experimentos em balões forneceram dados sobre a exposição de diversas classes de biomoléculas em um ambiente com condições similares às da superfície de Marte e sua detecção por espectroscopia Raman. No experimento da Garatéa II, algumas amostras não apresentaram nenhuma variação em suas assinaturas espectroscópicas, o que pode ser um indicativo de que elas são resistentes a este ambiente de "Marte úmido" e, portanto, potenciais bioassinaturas moleculares. Porém, novos voos de mais longa duração são necessários para confirmar tal conclusão. Outras amostras apresentaram variações espectroscópicas durante o voo, indicando quebras ou formações de ligações, como por exemplo os pigmentos $\beta$-caroteno e deinoxantina (o pigmento mais abundante na bactéria Deinococcus radiodurans). O grande desvio padrão da diminuição das intensidades dos picos Raman do $\beta$-caroteno não permitem uma conclusão concreta, mas os picos da deinoxantina claramente sofreram uma maior degradação do que os do $\beta$-caroteno, o 
que pode ser atribuído à maior capacidade antioxidante da deinoxantina. Portanto, as assinaturas espectroscópicas Raman do $\beta$-caroteno são mais fotoestáveis do que as da deinoxantina em um ambiente de "Marte úmido".

Em suma, todos os experimentos forneceram, de alguma maneira, informações úteis sobre as respostas espectroscópicas das biomoléculas-modelo selecionadas após serem expostas a diferentes condições ambientais, o que permitiu testar seus potenciais como bioassinaturas. Assim, é possível otimizar as técnicas e procedimentos tanto para o desenvolvimento de experimentos semelhantes com potenciais bioassinaturas em missões espaciais, quanto para sua eventual detecção em um ambiente espacial real.

\subsection{PERSPECTIVAS}

\subsubsection{No espaço: Garatéa $L$}

Brasil está atualmente desenvolvendo um nanosatélite para realizar experimentos de astrobiologia em ambiente espacial, semelhantes aos citados. O projeto brasileiro Garatéa L foi proposto, em 2016, para ser um CubeSat 6U que levará diferentes experimentos científicos à órbita da Lua, em uma oportunidade de voo de duas empresas britânicas em parceria com a ESA. Um dos experimentos deve expor biomoléculas às condições severas do ambiente espacial, com e sem proteção da magnetosfera, para estudar sua cinética de degradação, preservação e detectabilidade por espectroscopia no UV-Vis. A contribuição da candidata tem sido nas primeiras etapas do desenvolvimento deste experimento: revisão bibliográfica, escolha de amostras, testes de preparo das amostras para exposição, primeiros testes de irradiação em laboratório usando câmara de simulação de Marte e radiação síncrotron, e também usando balões estratosféricos, e testes com diferentes medições espectroscópicas.

Em setembro de 2016 as empresas britânicas Surrey Satellite Technology Limited (SSTL) e Goonhilly Earth Station (GES), em parceria com a Agência Espacial Européia (ESA) e a Agência Espacial do Reino Unido (UK Agency), anunciaram uma oportunidade de voo para pequenos payloads em uma missão lunar. Demonstramos interesse com a proposta de enviar um CubeSat 6U (de 6 unidades) carregando diferentes experimentos científicos à orbita da Lua (Figura 73, esquerda), entre eles um experimento de astrobiologia, e conseguimos um lugar nesta missão com um time inteiramente brasileiro. (103)

A missão, The Lunar Communications Pathfinder Mission, será enviada pelo lançador indiano PSLV-C11, e servirá de nave mãe para outras cinco missões internacionais que se 
utilizam de plataformas CubeSats e possuem objetivos distintos com a visitação da órbita ao redor da Lua. Além do transporte, a missão proposta pelos britânicos irá fornecer uma plataforma de telecomunicação entre a Terra e os CubeSats na Lua.

O projeto e construção do CubeSat, batizado de Garatéa-L (Garatéa = "busca-vidas", e L = Lunar), conta com times de diversas organizações além do nosso grupo no LNLS, como a Airvantis Aerospace R\&D Company, Instituto Mauá de Tecnologia (IMT), Universidade de São Paulo (USP), Instituto Nacional de Pesquisas Espaciais (INPE), Instituto Tecnológico de Aeronáutica (ITA), Universidade Federal de Santa Catarina (UFSC) e Pontifícia Universidade Católica (PUC-RS). Terá um custo total estimado de R \$ 35 milhões (menor que a mais barata das missões de espaço profundo já realizadas até hoje, no mundo todo), com financiamento em modelo PPP (parceria público-privada), e contribuirá para o desenvolvimento da pesquisa e exploração espacial no Brasil. O lançamento está proposto para 2020 em comemoração do aniversário de 50 anos do primeiro pouso tripulado na superfície lunar.

O experimento de astrobiologia, liderado pelo grupo brasileiro NAP/Astrobio, tem como objetivo principal aumentar nossa compreensão sobre os efeitos do ambiente espacial sobre a vida como a conhecemos. A órbita proposta para a sonda Garatéa-L a coloca além da proteção do campo geomagnético terrestre, portanto, diretamente exposta às partículas carregadas dos raios cósmicos, principalmente aquelas provenientes do vento solar. O experimento foi separado em duas etapas, visando a compreensão dos efeitos em nível molecular (experimento denominado "Secos") e de comunidade microbiana (experimento denominado "Molhados").

O experimento Secos é o foco de colaboração do presente projeto e, possivelmente, de projetos futuros. Com base nos experimentos anteriores em balões estratosféricos e simulações em laboratório, biomoléculas selecionadas serão expostas às condições extremas do espaço profundo, com e sem a proteção da magnetosfera terrestre. Com isso, será possível investigar os efeitos dessas condições sobre as moléculas importantes para a vida como a conhecemos, monitorando alterações moleculares que geram degradação, formação de novas espécies químicas, ou até complexificação molecular; além de estudar a detectabilidade de potenciais bioassinaturas moleculares em um ambiente espacial real, com todas as condições que não podem ser simuladas precisamente em laboratórios ou ambientes análogos.

A resposta molecular das amostras será analisada in situ e em tempo real por reflectância difusa ou absorção, utilizando um espectrômetro UV-Vis em miniatura, em fase de seleção pelo grupo. A Figura 73 (direita) mostra um possível esquema do experimento, baseado em reflectância difusa. Em contraste com os outros experimentos, como O/OREOS e OREOcube, que utilizaram o Sol como fonte de luz para o espectrofotômetro, nosso grupo pretende utilizar 
um arranjo de LED de baixo consumo de energia. Assim, não é necessária quase nenhuma correção para flutuações da intensidade da luz solar (devido à rotação ou oscilações do cubo, ao período orbital ou à baixa capacidade de "apontamento" ao Sol), o que simplifica a análise dos dados, mas custa mais energia (já considerada no design do módulo de energia).
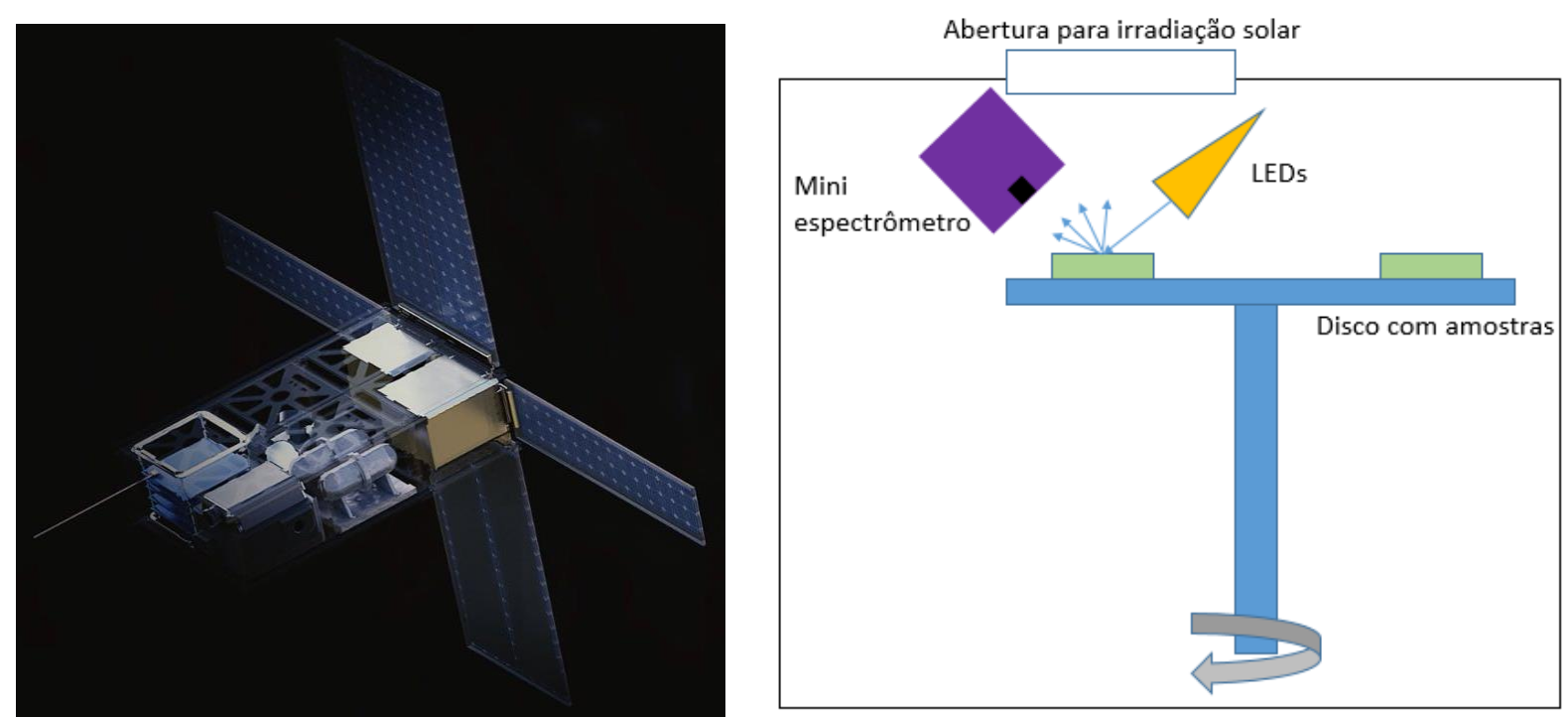

Figura 73 - Esquerda: Design proposto para a Garatéa-L. Direita: Possível esquema para análise das amostras no CubeSat, baseado em reflectância difusa.

Fonte: Elaborada pela autora

\subsubsection{Experimentos na estratosfera: Garatéa III}

Após o sucesso das missões Garatéa I e II, outro voo utilizando balão de alta-altitude já está sendo planejado para um futuro próximo - a missão Garatéa III. A gôndola utilizada na missão anterior já está sendo reformada e otimizada pelos alunos do grupo Zenith, e os experimentos de astrobiologia já estão sendo planejados pelo grupo responsável. O plano é enviar um mini espectrômetro UV-vis a bordo da gôndola para começar os testes de experimentos com análises in situ e em tempo real, visando, assim, uma validação dos experimentos que serão enviados no CubeSat futuramente. 


\section{REFERÊNCIAS}

1 RODRIGUES, F. et al. Astrobiology in Brazil: early history and perspectives. International Journal of Astrobiology, v. 11, n. 4, p. 189-202, 2012.

2 PACE, N. R. The universal nature of biochemistry. Proceedings of the National Academy of Sciences of the United States of America, v. 98, n. 3, p. 805-808, 2001.

3 BROCKS, J. J. Archean molecular fossils and the early rise of eukaryotes. Science, v. 285, n. 5430, p. 1033-1036, 1999.

4 EDWARDS, H. G. M. et al. Biomarkers and their Raman spectroscopic signatures: a spectral challenge for analytical astrobiology. Philosophical transactions A: mathematical, physical, and engineering sciences, v. 372, n. 2030, p. 20140193, 2014.

5 FOX, S.; STRASDEIT, H. Inhabited or uninhabited? Pitfalls in the interpretation of possible chemical signatures of extraterrestrial life. Frontiers in Microbiology, v. 8, 2017. doi: 10.3389/fmicb.2017.01622.

6 LEE, C.; BROCKS, J. J. Identification of carotane breakdown products in the 1.64 billion year old Barney Creek formation, McArthur Basin, northern Australia. Organic Geochemistry, v. 42, n. 4, p. 425-430, 2011.

7 SEREBRENNIKOVA, O. V.; MOZZHELINA, T. K. Features of porphyrin compounds in Cambrian oil shales from Yakutiya, Siberia. Organic Geochemistry, v. 21, n. 8-9, p. 891-895, 1994.

8 LEMEE, L. et al. Deinoxanthin: a new carotenoid isolated from Deinococcus radiodurans. Tetrahedron, v. 53, n. 3, p. 919-926, 1997.

9 COX, M. M.; BATTISTA, J. R. Deinococcus radiodurans - the consummate survivor. Nature Reviews Microbiology, v. 3, n. 11, p. 882-892, 2005.

10 PAULINO-LIMA, I. G. et al. Laboratory simulation of interplanetary ultraviolet radiation (broad spectrum) and its effects on Deinococcus radiodurans. Planetary and Space Science, v. 58, n. 10, p. 1180-1187, 2010.

11 BETA-CAROTENE. Disponível em: <https://commons.wikimedia.org/wiki/File:Betacarotene.svg>. Acesso em: 19 fev 2018.

12 CHLOROPHYLL A. Disponível em: <http://www.chemicalbook.com/ChemicalProductProperty_EN_CB5471362.htm>. Acesso em: 19 fev 2018.

13 ISLER, O.; GUTMANN, H.; SOLMS, U. Carotenoids. Basel: Birkhäuser Basel, 1971.

14 SMITH, R. A. The colours of life: an introduction to the chemistry of porphyrins and related compounds (Milgrom, Lionel R.). Journal of Chemical Education, v. 75, n. 4, p. 420, 1998.

15 CAMPBELL, M. K.; FARRELL, S. O. Biochemistry. Belmont, CA : Brooks/Cole, 2009.

16 NATIONAL INSTITUTE OF ADVANCED INDUSTRIAL SCIENCE AND TECHNOLOGY. Spectral database for organic compounds (SDBS). Disponível em: <http://sdbs.db.aist.go.jp>. Acesso em: 01 jan. 2017.

17 CHANG, H. et al. Characterization of natural dye extracted from wormwood and purple 
cabbage for dye-sensitized solar cells. International Journal of Photoenergy, v. 2013, 2013. doi: $10.1155 / 2013 / 159502$.

18 VÍTEK, P.: OSTERROTHOVÁ, K.; JEHLIČKA, J. Beta-carotene-A possible biomarker in the Martian evaporitic environment: Raman micro-spectroscopic study. Planetary and Space Science, v. 57, n. 4, p. 454-459, 2009.

19 EVANS, J. R.; ANDERSON, J. M. Absolute absorption and relative fluorescence excitation spectra of the five major chlorophyll-protein complexes from spinach thylakoid membranes. Biochimica et Biophysica Acta - bioenergetics, v. 892, n. 1, p. 75-82, 1987.

20 ALSHIBLI, K. A.; HASAN, A. Strength properties of JSC-1A lunar regolith simulant. Journal of Geotechnical and Geoenvironmental Engineering, v. 135, n. 5, p. 673-679, 2009.

21 ALEXIADIS, A.; ALBERINI, F.; MEYER, M. E. Geopolymers from lunar and Martian soil simulants. Advances in Space Research. v. 59, n. 1. p. 490-495, 2017.

22 ZHOU, C. H. Clay mineral-based catalysts and catalysis. Applied Clay Science, v. 53, n. 2. p. 85-86, 2011.

23 PEARSON, V. K. et al. Clay mineral-organic matter relationships in the early solar system. Meteoritics \& Planetary Science, v. 37, n. 12. p. 1829-1833, 2002.

24 EHLMANN, B. L. et al. Subsurface water and clay mineral formation during the early history of Mars. Nature, v. 479, n. 7371. p. 53-60, 2011.

25 FREISSINET C. et al. Organic molecules in the Sheepbed Mudstone, Gale Crater, Mars. Journal of Geophysical Research: planets, v. 120, n. 3. p. 495-514, 2015.

26 EIGENBRODE J. L. et al. Organic matter preserved in 3-billion-year-old mudstones at Gale crater, Mars. Science, v. 360, n. 6393. p. 1096-1101. 2018.

27 ALLEN C. C. et al. Martian soil simulant available for scientific, educational study. Eos, Transactions American Geophysical Union, v. 79, n. 34. p. 405-405. 1998.

28 RIEDER R. et al. The chemical composition of Martian soil and rocks returned by the mobile alpha proton X-ray spectrometer: preliminary results from the X-ray mode. Science, v. 278, n.5344. p. 1771-1774. 1997.

29 GUSTAFSON, R. JSC-1A lunar regolith simulant. Disponível em:

$<$ https://isru.msfc.nasa.gov/lib/workshops/2009/03_JSC-

1A_Lunar_RegSimulant_Update_BGustafson.pdf>. Acesso em: 11 mar 2018.

30 MATERIAL SAFETY DATA SHEET. JSC Mars-1A . 2005. Disponível em: $<$ https://isru.msfc.nasa.gov/lib/Documents/JSC-

1a_MATERIAL_SAFETY_DATA_SHEET.pdf>. Acesso em: 11 abr 2018.

31 TUCHIN, V. V. Tissue optics and photonics: biological tissue structures. Journal of Biomedical Photonics \& Engineering, v. 1, n. 1. p. 3-21, 2015.

32 ATKINS, P. W.; PAULA, J. Atkins' physical chemistry. Oxford: Oxford University Press, 2010.

33 CRAIEVICH, A. F.; RODRIGUES, R. The Brazilian synchrotron light source. Hyperfine Interactions, v. 113, n. 1/4, p. 465-475, 1998.

34 LARMOR radiation - radiation from an accelerated charge. 2008. Disponível em: 
<https://www.cv.nrao.edu/course/astr534/PDFnewfiles/LarmorRad.pdf >. Acesso em: $23 \mathrm{dez}$ 2017.

35 JACKSON, J. D. Classical electrodynamics. 3rd ed. New York: John Wiley \& Sons, 1999. 36 HOW is synchrotron light created? Disponível em: <http://www.synchrotron.org.au/synchrotron-science/how-is-synchrotron-light-created>. Acesso em: $25 \mathrm{dez} 2018$.

37 TAVARES, P. F.; BRUM, J. A. The Brazilian synchrotron light source. 2005. Disponível em: https://accelconf.web.cern.ch/accelconf/p05/PAPERS/WOAB003.PDF. Acesso em: 30 maio 2017.

38 CAVASSO FILHO, R. L. Advances on the Brazilian toroidal grating monochromator (TGM) beamline. Journal of Electron Spectroscopy and Related Phenomena, v. 144-147, p. 1125-1127, 2005. doi: 10.1016/j.elspec.2005.01.253.

39 LINHA DE LUZ TGM - LNLS. Disponível em: <http://lnls.cnpem.br/linhas-deluz/tgm/overview/>. Acesso em: $25 \mathrm{dez} 2017$.

40 BRASIL. Ministério da Ciência, Tecnologia e Inovação. Instituto Nacional de Pesquisas Espaciais. Setor de lançamento de balões. Disponível em: <http://www.slb.inpe.br/>. Acesso em: 31 maio 2017.

41 PLA-GARCÍA, J. et al. Weather report Mars Year 33, Month 10. 2017. Disponível em: $<$ http://cab.inta-csic.es/rems/wp-content/uploads/2017/03/Gale_weather_report_Mars-Year33_Month_10.pdf>. Acesso em: 23 jan. 2018.

42 KHODADAD, C. L. et al. Stratosphere conditions inactivate bacterial endospores from a Mars spacecraft assembly facility. Astrobiology, v. 17, n. 4, p. 337, 2017.

43 ZENITH. Disponível em: <https://www.facebook.com/zenitheesc/>. Acesso em: 23 maio 2017.

44 COTTIN, H. et al. Photochemical studies in low earth orbit for organic compounds related to small bodies, Titan and Mars. current and future facilities. Bulletin de la Societe Royale des Sciences de Liege, v. 84, p. 60-73, 2015.

45 GUAN, Y. Y. et al. UVolution: compared photochemistry of prebiotic organic compounds in low Earth orbit and in the laboratory. Planetary and Space Science, v. 58, n. 10, p. 13271346, 2010.

46 BARBIER, B. Photochemical processing of amino acids in Earth orbit. Planetary and Space Science, v. 46, n. 4, p. 391-398, 1998.

47 BARBIER, B. et al. Exposure of amino acids and derivatives in the Earth orbit. Planetary and Space Science, v. 50, n. 4, p. 353-359, 2002.

48 BOILLOT, F. et al. The Perseus exobiology mission on MIR: behaviour of amino acids and peptides in earth orbit. Origins of Life and Evolution of the Biosphere, v. 32, n. 4, p. 359-385, 2002.

49 EHRENFREUND, P. et al. The ORGANICS experiment on BIOPAN V: UV and space exposure of aromatic compounds. Planetary and Space Science, v. 55, n. 4, p. 383-400, 2007.

50 STALPORT, F. et al. UVolution, a photochemistry experiment in low earth orbit: investigation of the photostability of carboxylic acids exposed to mars surface UV radiation 
conditions. Astrobiology, v. 10, n. 4, p. 449-461, 2010.

51 STALPORT, F. et al. UVolution, a photochemistry experiment in low earth orbit: Investigation of the photostability of carbonates exposed to martian-like UV radiation conditions. Planetary and Space Science, v. 58, n. 12, p. 1617-1624, 2010.

52 BERTRAND, M. et al. The process experiment: exposure of amino acids in the EXPOSEE experiment on the international space station and in laboratory simulations. Astrobiology, v. 12 , n. 5, p. 426-435, 2012.

53 NOBLET, A. et al. The process experiment: amino and carboxylic acids under mars-like surface UV radiation conditions in low-earth orbit. Astrobiology, v. 12, n. 5, p. 436-444, 2012.

54 COTTIN, $\mathrm{H}$. et al. The process experiment: an astrochemistry laboratory for solid and gaseous organic samples in low-earth orbit. Astrobiology, v. 12, n. 5, p. 412-425, 2012.

55 COTTIN, H. et al. The AMINO experiment: a laboratory for astrochemistry and astrobiology on the EXPOSE-R facility of the International Space Station. International Journal of Astrobiology, v. 14, n. 1, p. 67-77, 2015.

56 BERTRAND, M. et al. The AMINO experiment: exposure of amino acids in the EXPOSE$\mathrm{R}$ experiment on the International Space Station and in laboratory simulations. International Journal of Astrobiology, v. 14, n. 1, p. 89-97, 2015.

57 CARRASCO, N. et al. The AMINO experiment: methane photolysis under Solar VUV irradiation on the EXPOSE-R facility of the International Space Station. International Journal of Astrobiology, v. 14, n. 1, pp. 79-87, 2015.

58 VERGNE, J. et al. The AMINO experiment: RNA stability under solar radiation studied on the EXPOSE-R facility of the International Space Station. International Journal of Astrobiology, v. 14, n. 1, p. 99-103, 2015.

59 DEMETS, R. et al. Window contamination on expose-R. International Journal of Astrobiology, v. 14, n. 1, p. 33-45, 2015.

60 BRAMALL, N. E. et al. The development of the space environment viability of organics (SEVO) experiment aboard the organism/organic exposure to orbital stresses (O/OREOS) satellite. Planetary and Space Science, v. 60, n. 1, p. 121-130, 2012.

61 MATTIODA, A. et al. The O/OREOS mission: first science data from the space environment viability of organics (SEVO) payload. Astrobiology, v. 12, n. 9, p. 841-853, 2012.

$62 \mathrm{COOK}$, A. M. et al. Sevo on the ground: design of a laboratory solar simulation in support of the O/OREOS mission. Astrophysical Journal, Supplement Series, v. 210, n. 2, p. 15, 2014.

63 EHRENFREUND, P. et al. The O/OREOS mission-astrobiology in low earth orbit. Acta Astronautica, v. 93, p. 501-508, 2014.

64 COOK, A. M. et al. The organism/organic exposure to orbital stresses (O/OREOS) satellite: radiation exposure in low-earth orbit and supporting laboratory studies of iron tetraphenylporphyrin chloride. Astrobiology, v. 14, n. 2, p. 1-15, 2014.

65 BRYSON, K. L. et al. The ORGANIC experiment on EXPOSE-R on the ISS: flight sample preparation and ground control spectroscopy. Advances in Space Research, v. 48, n. 12, p. 1980-1996, 2011.

66 BRYSON, K. L. et al. First results of the ORGANIC experiment on EXPOSE-R on the ISS. 
International Journal of Astrobiology, v. 14, n. 1, p. 55-66, Jan. 2015.

67 DEMETS, R. The expose-R2 mission : astrobiology and astrochemistry in low earth orbit. In: COSPAR SCIENTIFIC ASSEMBLY, 40., 2014. Moscow. Abstract... Moscow: ESAESTEC (HSO-USB), 2014.

68 DE VERA, J.-P. et al. Supporting Mars exploration: BIOMEX in low earth orbit and further astrobiological studies on the Moon using Raman and PanCam technology. Planetary and Space Science, v. 74, n. 1, p. 103-110, 2012.

69 ELSAESSER, A. et al. Organics exposure in orbit (OREOcube): a next-generation space exposure platform. Langmuir, v. 30, n. 44, p. 13217-13227, 2014.

70 KAPLAN, L. D.; MUENCH, G.; SPINRAD, H. An analysis of the spectrum of mars. Astrophysical Journal, v. 139, n. 1, 1964. doi: 10.1086/147736.

71 WHITEWAY, J. A. et al. Mars water-ice clouds and precipitation. Science, v325, n. 5936, p. $68,2009$.

72 HECHT, M. H. et al. Detection of perchlorate and the soluble chemistry of martian soil at the Phoenix lander site. Science, v. 325, n. 5936, p. 64-67, 2009.

73 MARTIN-MUR, T. J. et al. Mars science laboratory navigation results. Disponível em: <http://www.issfd.org/ISSFD_2012/ISSFD23_IN1_1.pdf>. Acesso em: 2 jan. 2018.

74 HASSLER, D. M. et al. Mars' surface radiation environment measured with the Mars science laboratory's curiosity rover. Science, v. 343, n. 6169, p. 1244797, 2014.

75 VAGO, J. et al. ESA ExoMars program: the next step in exploring Mars. Solar System Research, v. 49, n. 7, p. 518-528, 2015.

76 OBJECTIVES: here's what the mars 2020 rover would do. Disponível em: <https://mars.nasa.gov/mars2020/mission/science/objectives/>. Acesso em: 19 fev. 2018.

77 SIEBERT, F.; HILDEBRANDT, P. Theory of infrared absorption and Raman spectroscopy. Weinheim: Wiley-VCH Verlag GmbH \& Co. KGaA, 2008.

78 FLORENZANO, F. H. Caracterização de polímeros: infravermelho com transformada de Fourier (FT-IR). Disponível em: <http://slideplayer.com.br/slide/7305176/\#>. Acesso em: 13 mar. 2018.

79 TRANSFORMADA de Fourier. Disponível em: <http://www.angelfire.com/psy/quimica/FTIR.htm>. Acesso em: 13 abr. 2018.

80 RAMAN, C. V. A new radiation. Indian Journal of Physics, v. 2, p. 387-398, 1928.

81 NASDALA, L. et al. Raman spectroscopy: analytical perspectives in mineralogical research. In: BERAN, A.; LIBOWITZKY, E. (Ed.) Spetroscopic methods in mineralogy. Eötvös: Eötvös University Press, 2004. cap. 7. p. 281. (EMU notes mineral, v. 6)

82 THE PHYSICS CLASSROOM. Specular vs. diffuse reflection. Disponível em: <http://www.physicsclassroom.com/class/refln/Lesson-1/Specular-vs-Diffuse-Reflection>. Acesso em: 14 mar. 2018.

83 TORRENT, J. V. BARRÓN, V. Diffuse reflectance spectroscopy. 2008. Disponível em: <https://pdfs.semanticscholar.org/7aef/ca85839ef34e145a7a503b4113b55b00abe2.pdf>.

Acesso em: 23 jan. 2017. 
84 MAURICE, S. et al. Raman laser spectrometer (RLS) for Exomars 2018 Rover Mission. Lunar and Planetary Science Conference, v. 44, p. 2-3, 2013.

85 BEEGLE, L. W. et al. SHERLOC: an investigation for Mars 2020. 2016. Disponível em: <https://www.hou.usra.edu/meetings/biosignature2016/pdf/2022.pdf>. Acesso em: 23 jan. 2017.

86 EDWARDS, H. G. M.; HUTCHINSON, I. INGLEY, R. The ExoMars Raman spectrometer and the identification of biogeological spectroscopic signatures using a flight-like prototype. Analytical and Bioanalytical Chemistry, v. 404, n. 6-7, p. 1723-1731, 2012.

87 SCHUERGER, A. C. et al Survival of endospores of Bacillus subtilis on spacecraft surfaces under simulated martian environments: Implications for the forward contamination of Mars. Icarus, v. 165, n. 2. p. 253-276, 2003.

88 ZHENG, X. et al. Self-referencing Raman probes for quantitative analysis. Applied Spectroscopy, v. 55, n. 4, p. 382-388, 2001.

89 GALLO, T. M. Implicações da resiliência de biomoléculas e efeitos de substrato em ambientes planetários simulados de alta radiação para a detecção de bioassinaturas espectroscópicas. 2016. Dissertação (Mestrado) - Instituto de Geociências e Ciências Exatas, Universidade Estadual Paulista, Rio Claro, 2016.

90 GLOBAL SPACE BALLOON CHALLENGE (GSBC). Disponível em: <https://www.balloonchallenge.org/>. Acesso em: 3 ago. 2016.

91 SMITH, D. J.; GRIFFIN, D. W.; SCHUERGER, A. C. Stratospheric microbiology at $20 \mathrm{~km}$ over the Pacific Ocean. Aerobiologia (Bologna), v. 26, n. 1, p. 35-46, 2010.

92 SMITH, D. J. et al. Microbial survival in the stratosphere and implications for global dispersal. Aerobiologia (Bologna), v. 27, n. 4, p. 319-332, 2011.

93 SCHEINMANN, F. An introduction to spectroscopic methods for the identification of organic compounds. New York: Pergamon Press, 1970.

94 ALL-TRANS-RETINAL. Disponível em: <https://commons.wikimedia.org/wiki/File:Alltrans-Retinal2.svg>. Acesso em: 15 jan. 2018.

95 RETINOL. Disponível em: <https://commons.wikimedia.org/wiki/File:Retinol.png>. Acesso em: 15 jan. 2018.

96 MARSHALL, C. P.; OLCOTT MARSHALL, A. The potential of Raman spectroscopy for the analysis of diagenetically transformed carotenoids. Philosophical Transactions of the Royal Society A: mathematical, physical and engineering sciences, v. 368, n. 1922, p. 3137-3144, 2010.

97 GIOVANNETTI, R. The use of spectrophotometry UV-Vis for the study of porphyrins. 2012. Disponível em: <https://cdn.intechopen.com/pdfs-wm/37656.pdf>. Acesso em: 23 jan. 2016.

98 BERNSTEIN, M. P. The lifetimes of nitriles $\left(-\mathrm{C}^{*} \mathrm{~N}\right)$ and acids $(-\mathrm{COOH})$ during ultraviolet photolysis and their survival in space. Astrophysical Journal, v. 601, n. 1, p. 365-370, 2003.

$99 \mathrm{POCH}, \mathrm{O}$. et al. Laboratory insights into the chemical and kinetic evolution of several organic molecules under simulated Mars surface UV radiation conditions. Icarus, v. 242, n. 1, p. 50-63, 2014.

100 TOBISKA, W. K. et al. The SOLAR2000 empirical solar irradiance model and forecast 
tool. Journal of Atmospheric and Solar-Terrestrial Physics, v. 62, n. 14, p. 1233-1250, 2000.

101 MIRROR REFLECTIVITY. Disponível em: <http://henke.lbl.gov/optical_constants/mirror2.html>. Acesso em: 17 out. 2017.

102 DARTNELL, L. R. et al. Destruction of Raman biosignatures by ionising radiation and the implications for life detection on Mars. Analytical and Bioanalytical Chemistry, v. 403, n. 1, p. 131-144, 2012.

103 FONSECA, L. Garatéa missão lunar. Disponível em: <http://www.garatea.space/>. Acesso em: 11 mar. 2018. 
APÊNDICE A - Espectros complementares dos experimentos na AstroCam

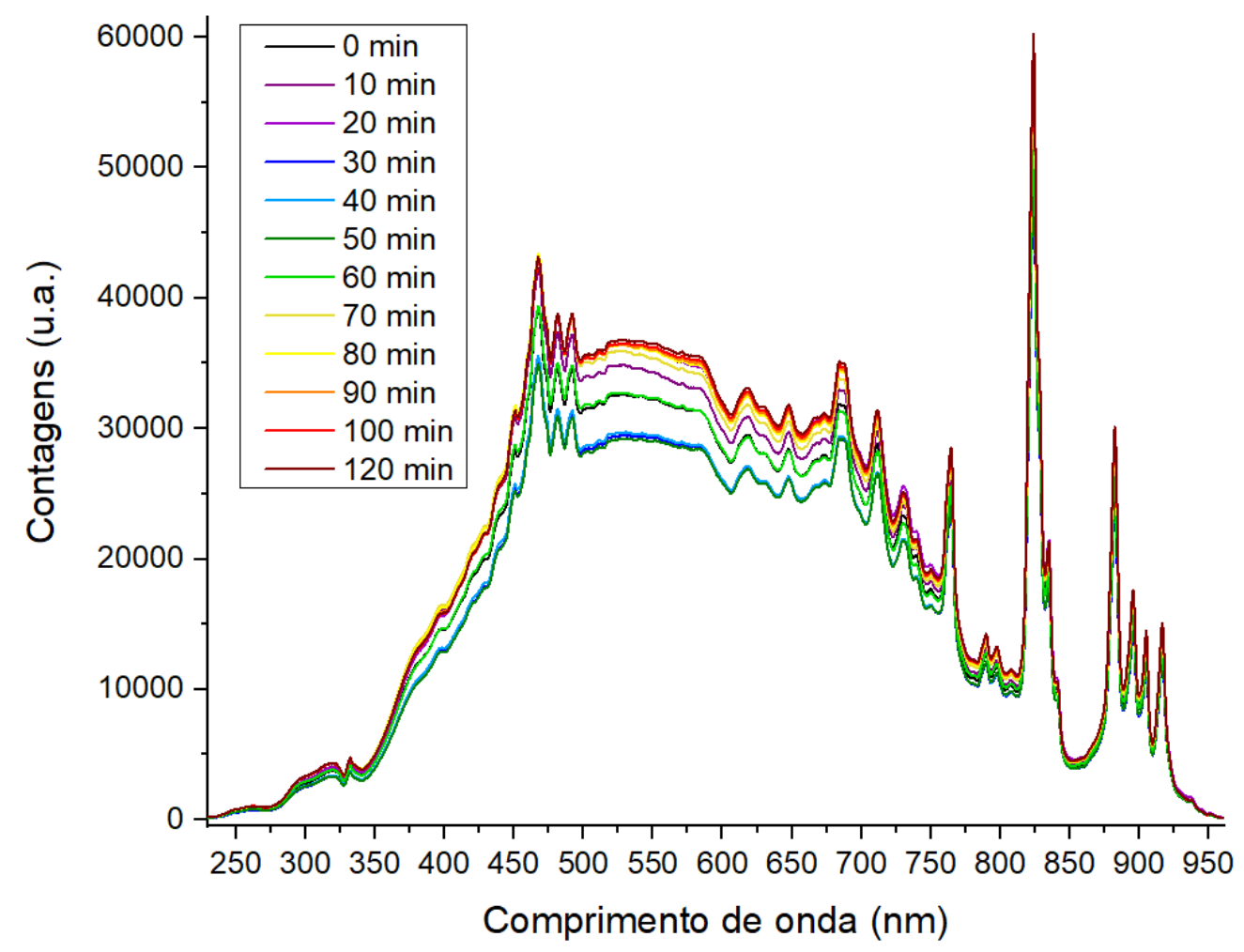

Figura 74 - Monitoramento do comportamento da lâmpada do simulador solar da AstroCam. Fonte: Elaborada pela autora

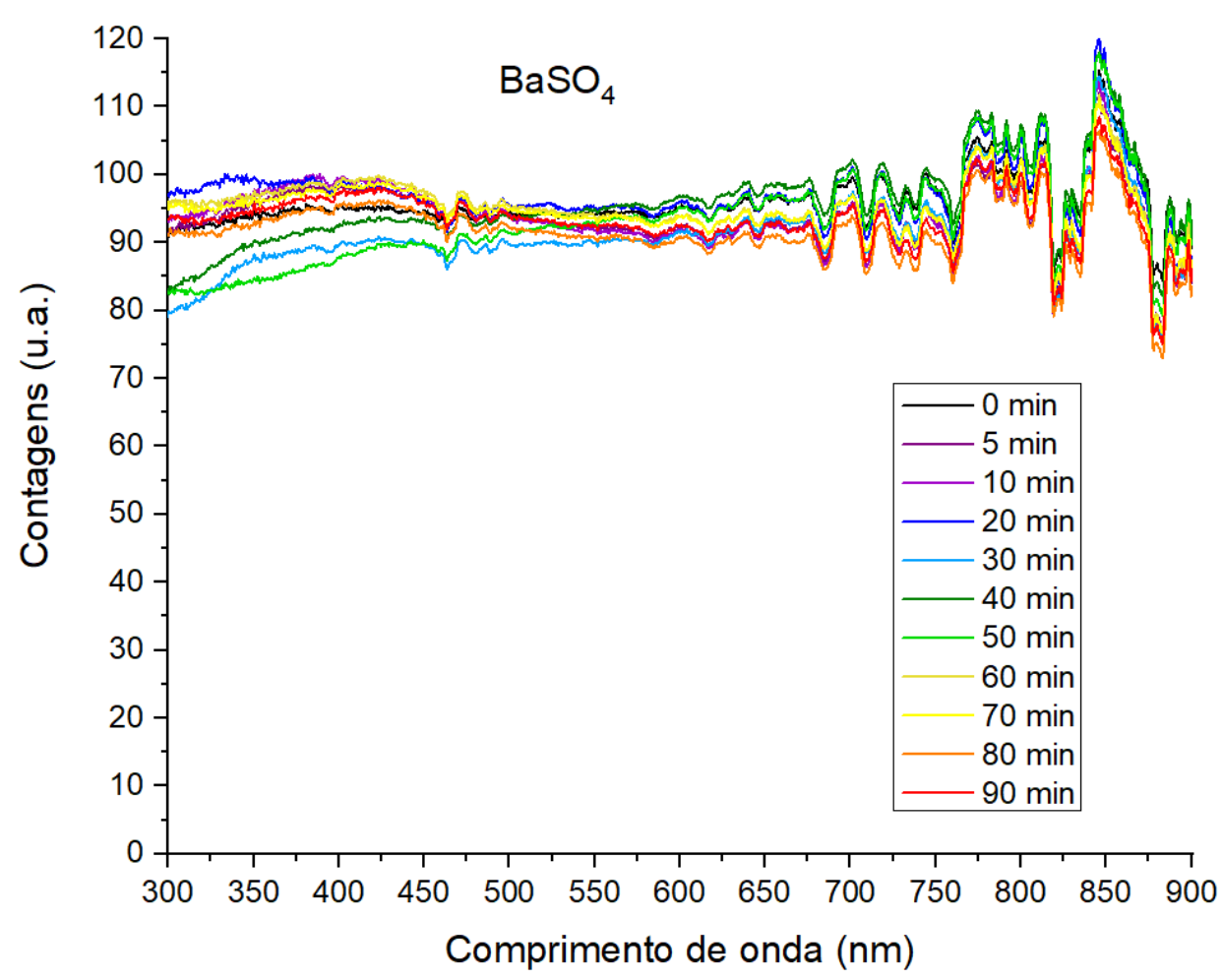

Figura 75 - Irradiação do branco sulfato de bário $\left(\mathrm{BaSO}_{4}\right)$ com o simulador solar da AstroCam. Fonte: Elaborada pela autora 


\section{APÊNDICE B - Espectros complementares dos experimentos na linha TGM}
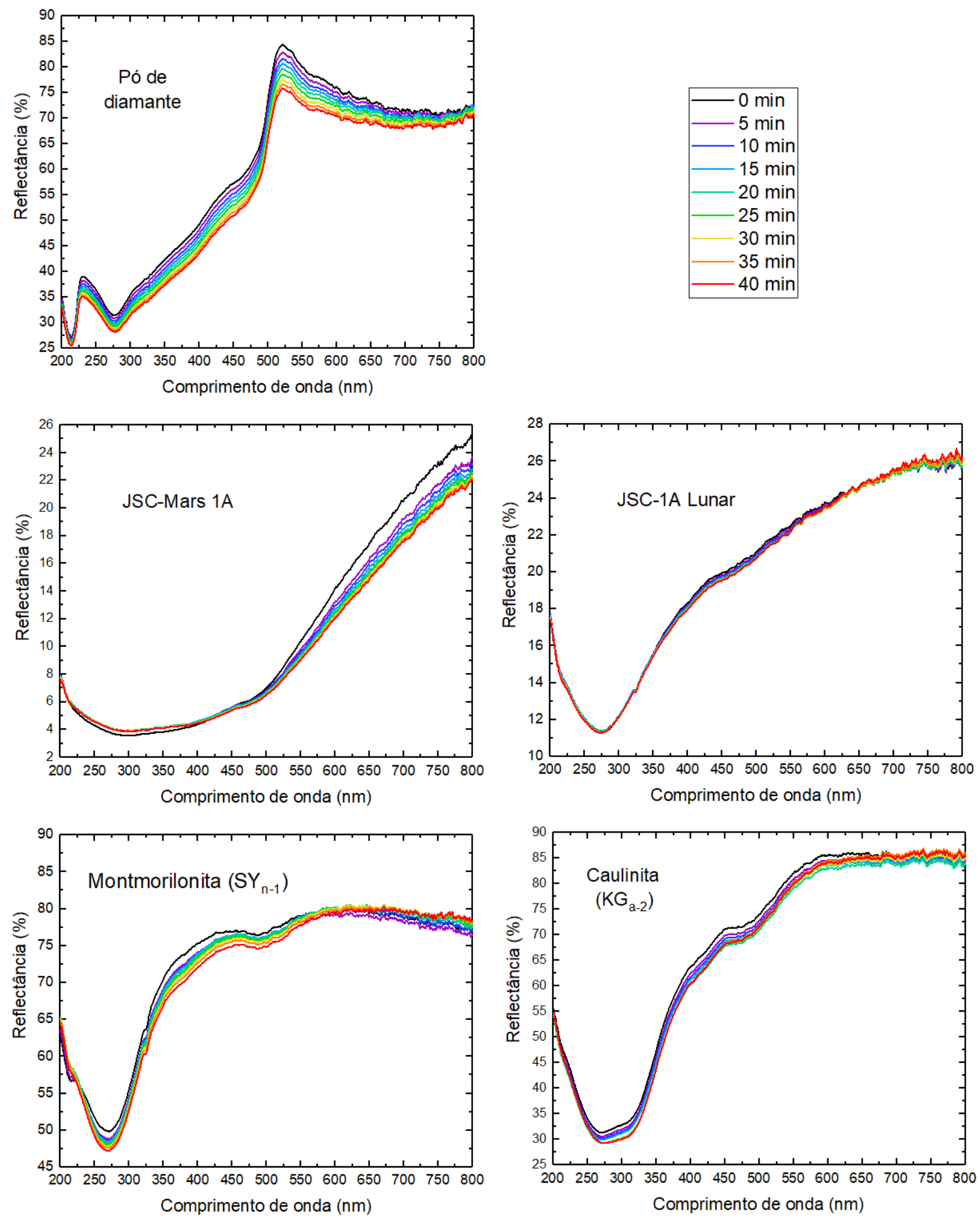

Figura 76 - Espectros de reflectância no UV-Vis obtidos durante as irradiações com luz síncrotron de filmes de $\beta$-caroteno.

Fonte: Elaborada pela autora 


\section{APÊNDICE C - Espectros complementares dos experimentos da Garatéa II}

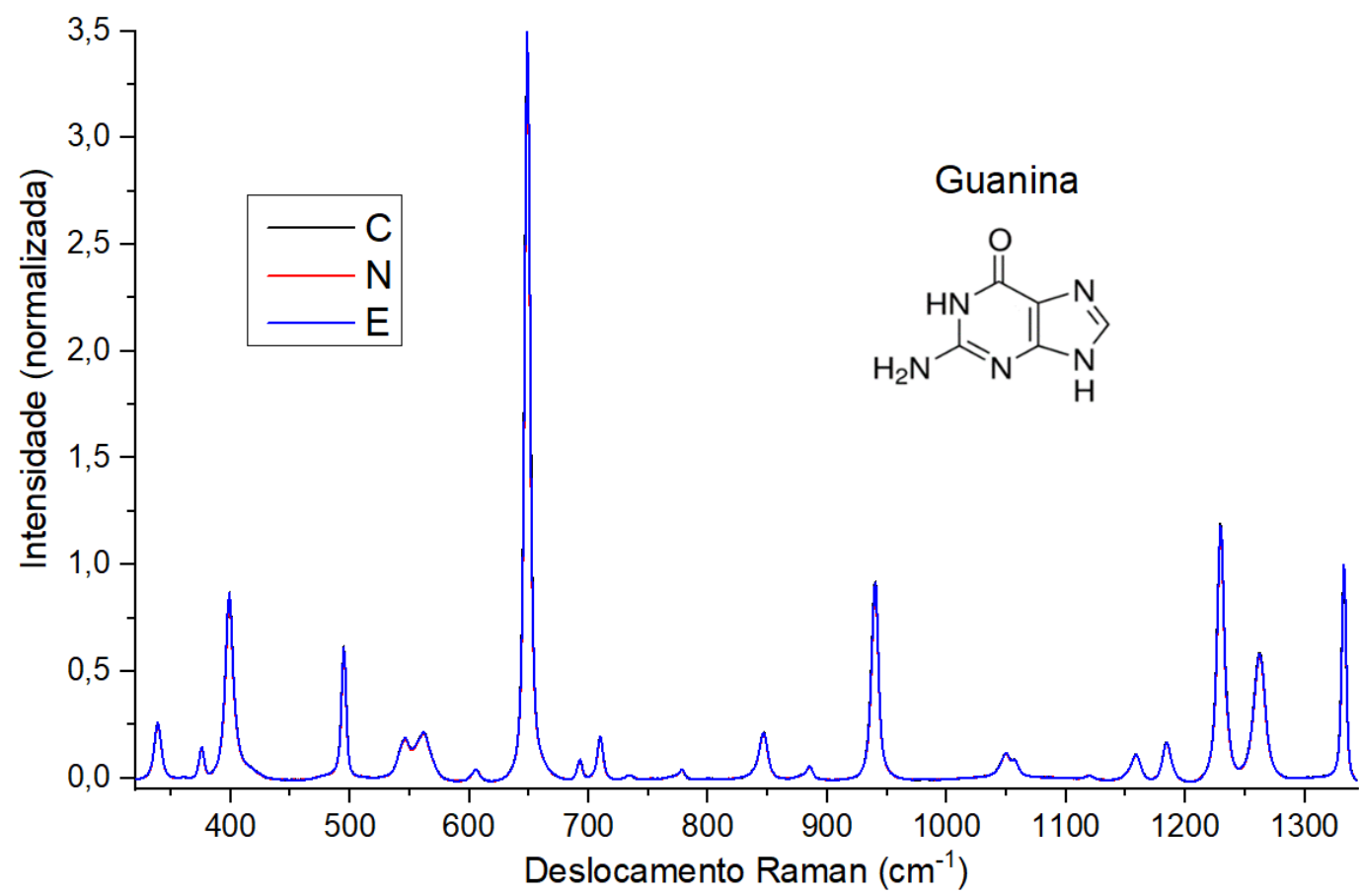

Figura 77 - Espectros Raman da guanina nas 3 condições experimentais: exposta à radiação, não exposta à radiação e controle em Terra.

Fonte: Elaborada pela autora

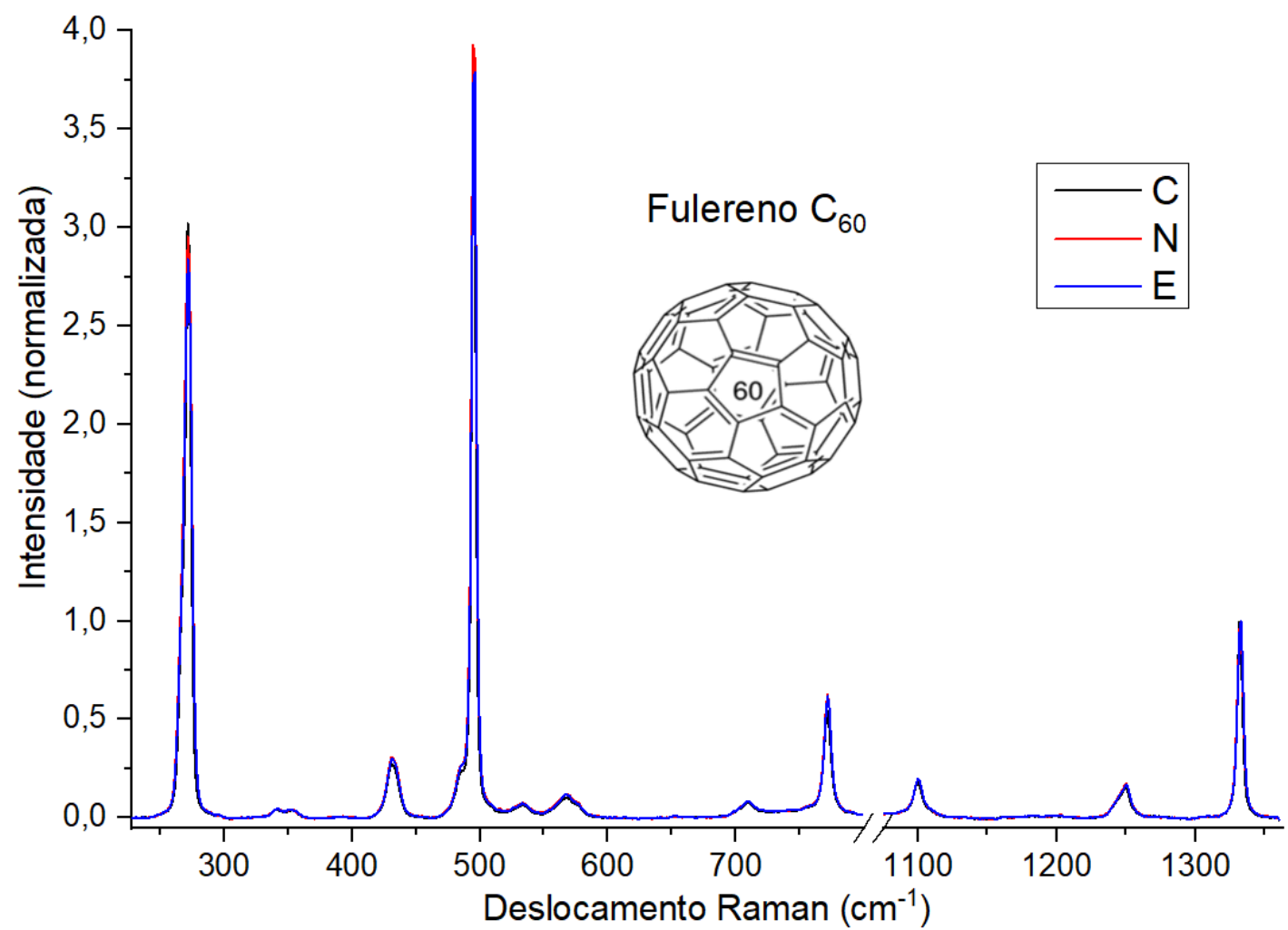

Figura 78 - Espectros Raman da fulereno $\mathrm{C}_{60}$ nas 3 condições experimentais: exposta à radiação, não exposta à radiação e controle em Terra.

Fonte: Elaborada pela autora 


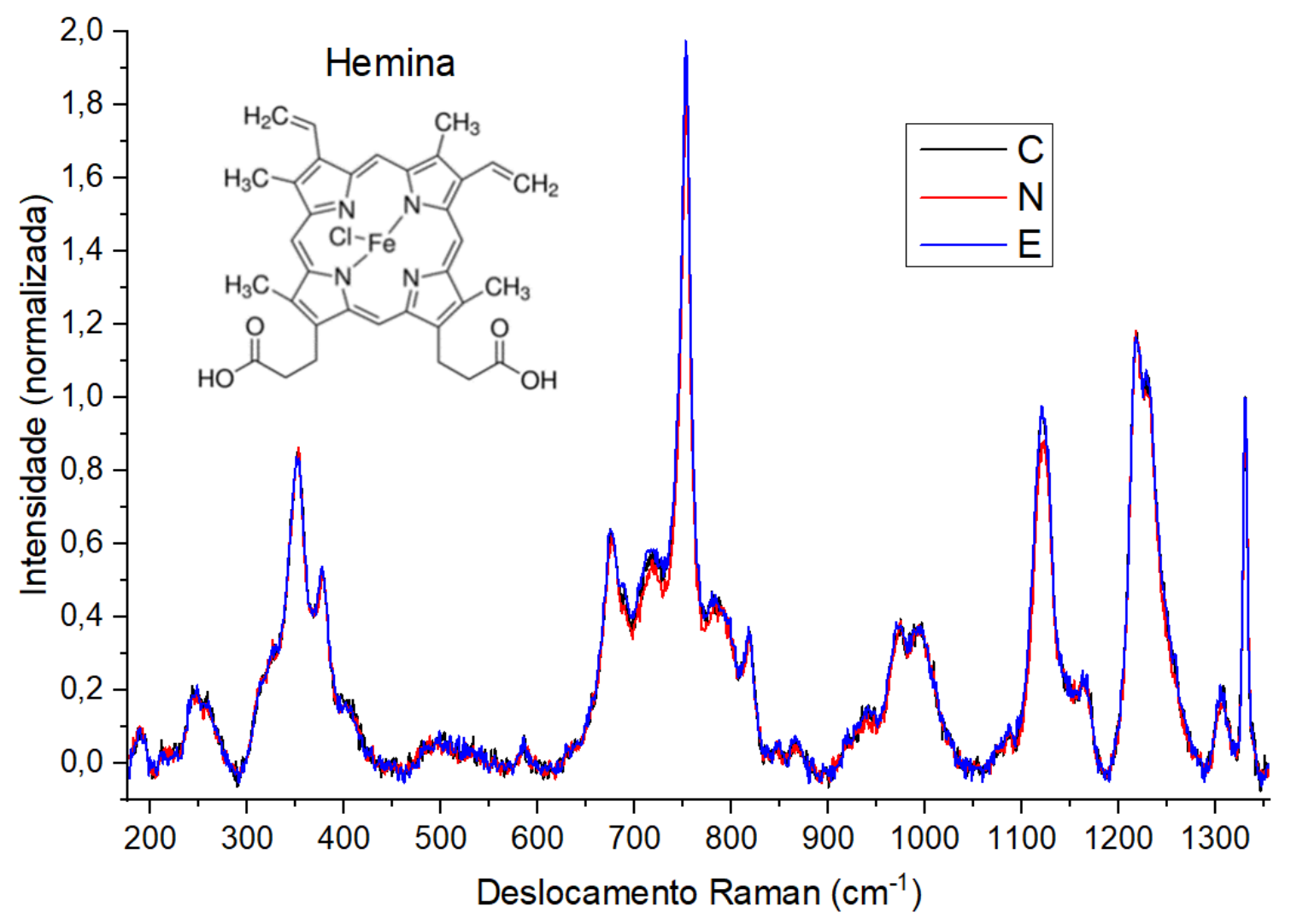

Figura 79 - Espectros Raman da hemina nas 3 condições experimentais: exposta à radiação, não exposta à radiação e controle em Terra.

Fonte: Elaborada pela autora

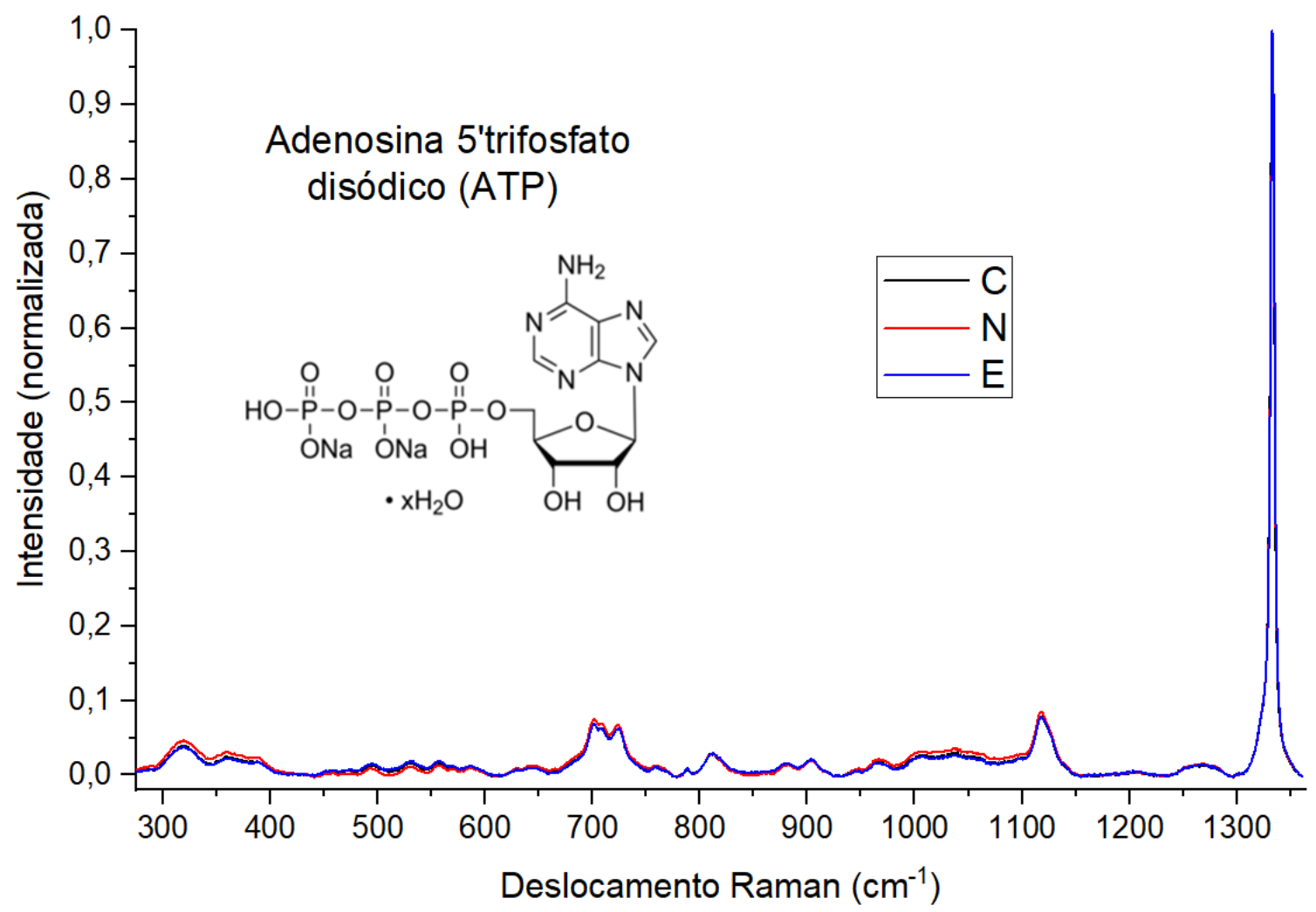

Figura 80 - Espectros Raman do ATP nas 3 condições experimentais: exposta à radiação, não exposta à radiação e controle em Terra.

Fonte: Elaborada pela autora 


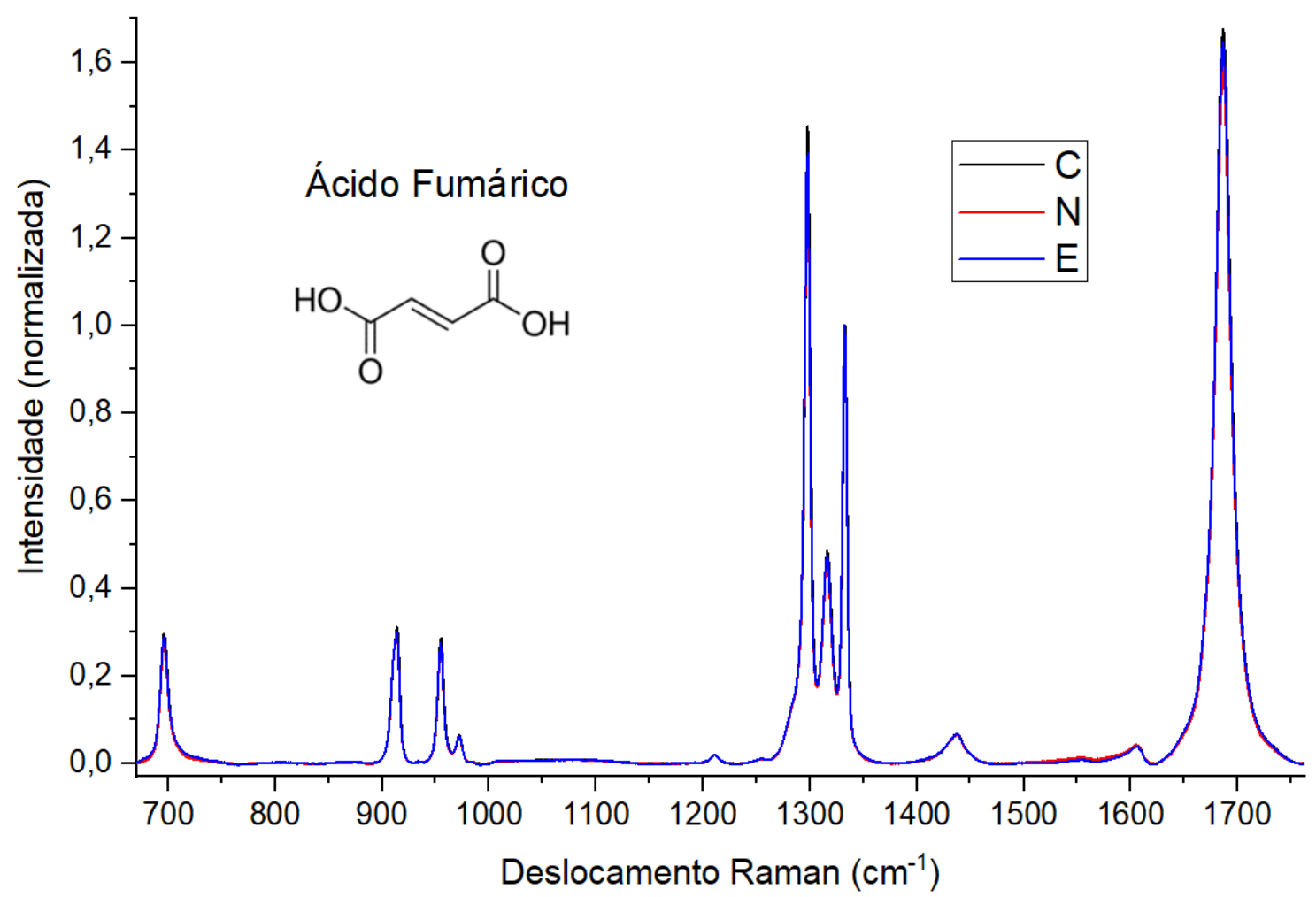

Figura 81 - Espectros Raman do ácido fumárico nas 3 condições experimentais: exposta à radiação, não exposta à radiação e controle em Terra.

Fonte: Elaborada pela autora

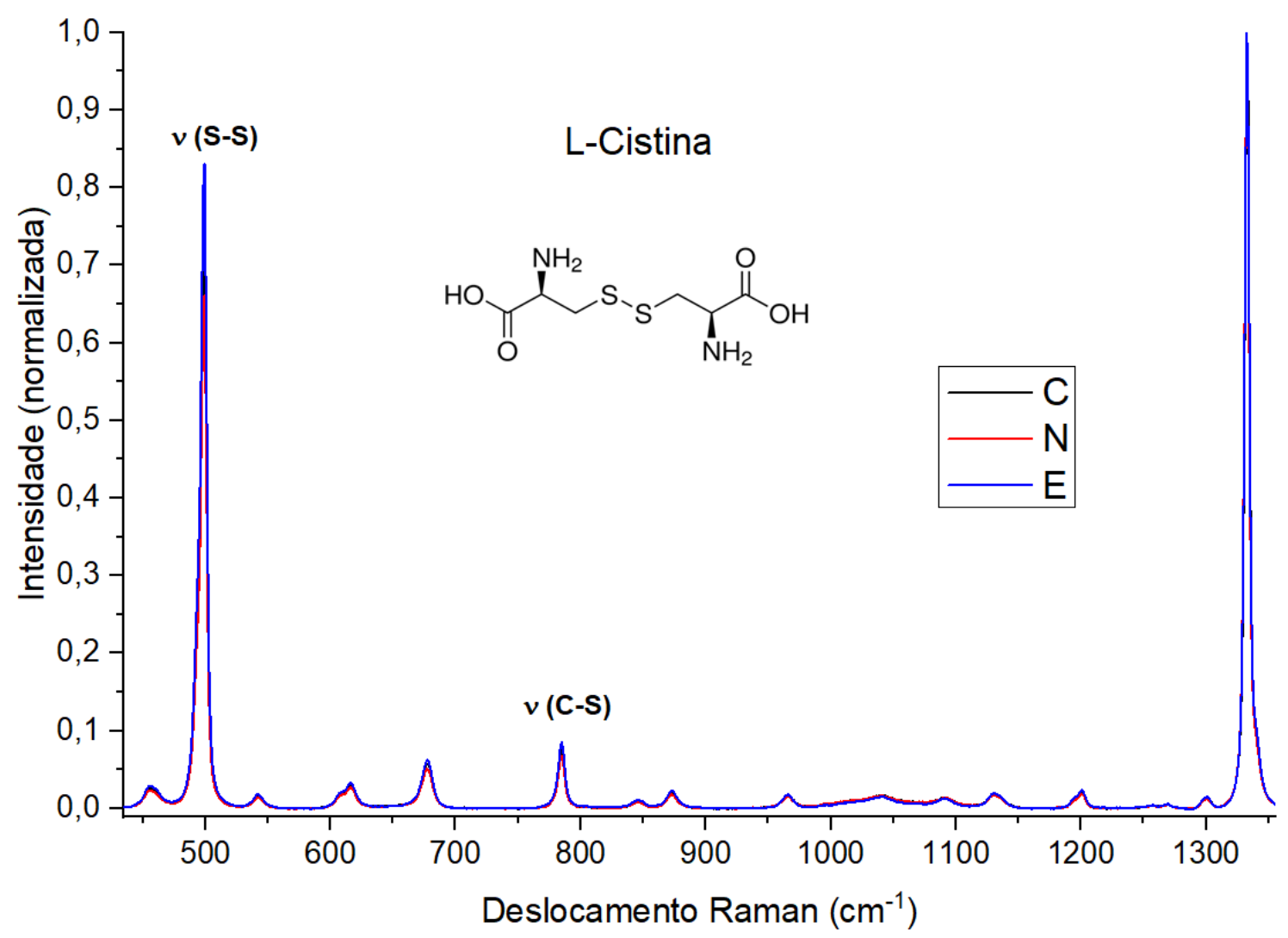

Figura 82 - Espectros Raman da L-cistina nas 3 condições experimentais: exposta à radiação, não exposta à radiação e controle em Terra. 


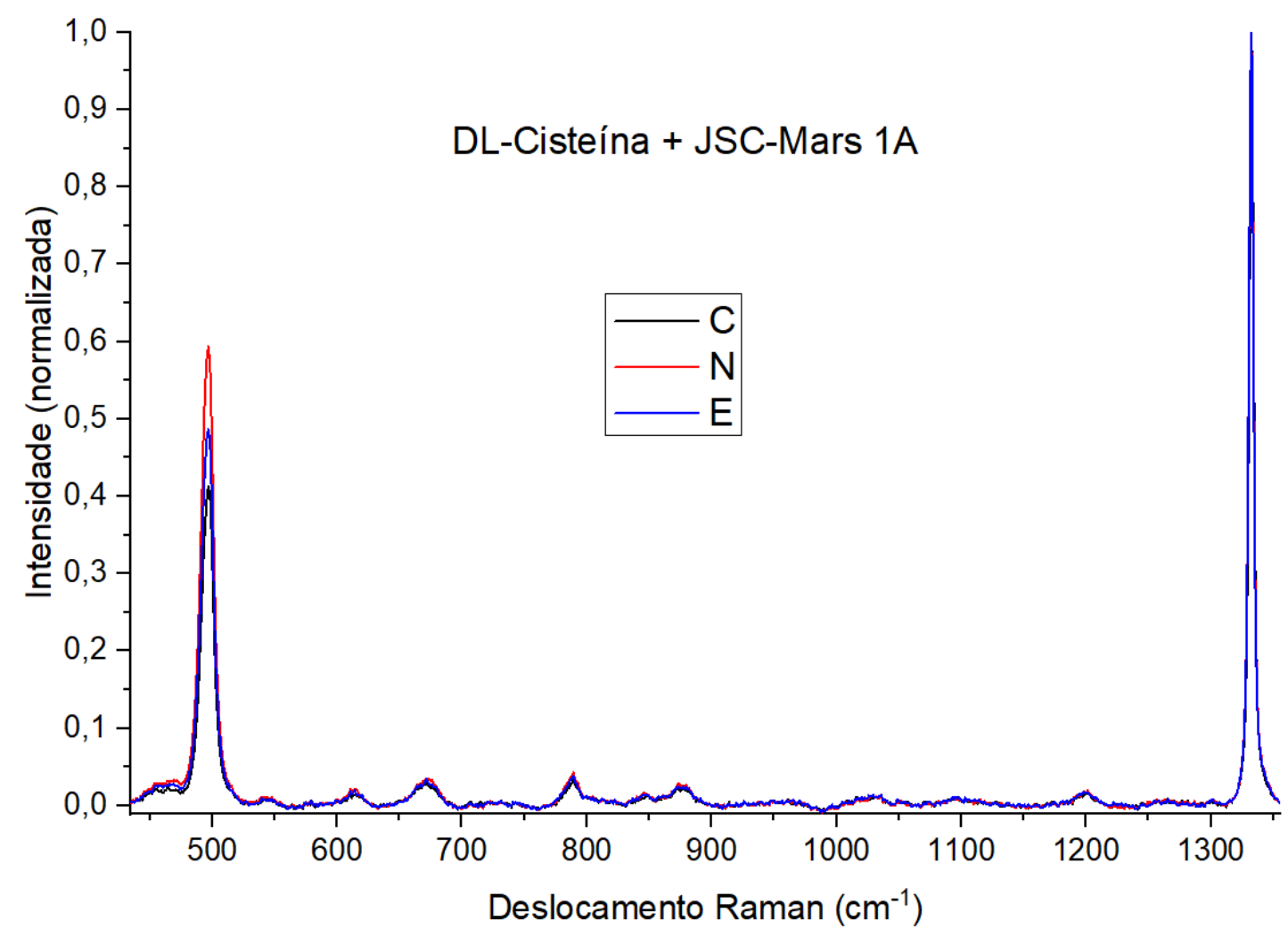

Figura 83 - Espectros Raman da DL-cisteína misturada com o solo simulante do regolito de Marte nas 3 condições experimentais: exposta à radiação, não exposta à radiação e controle em Terra.

Fonte: Elaborada pela autora

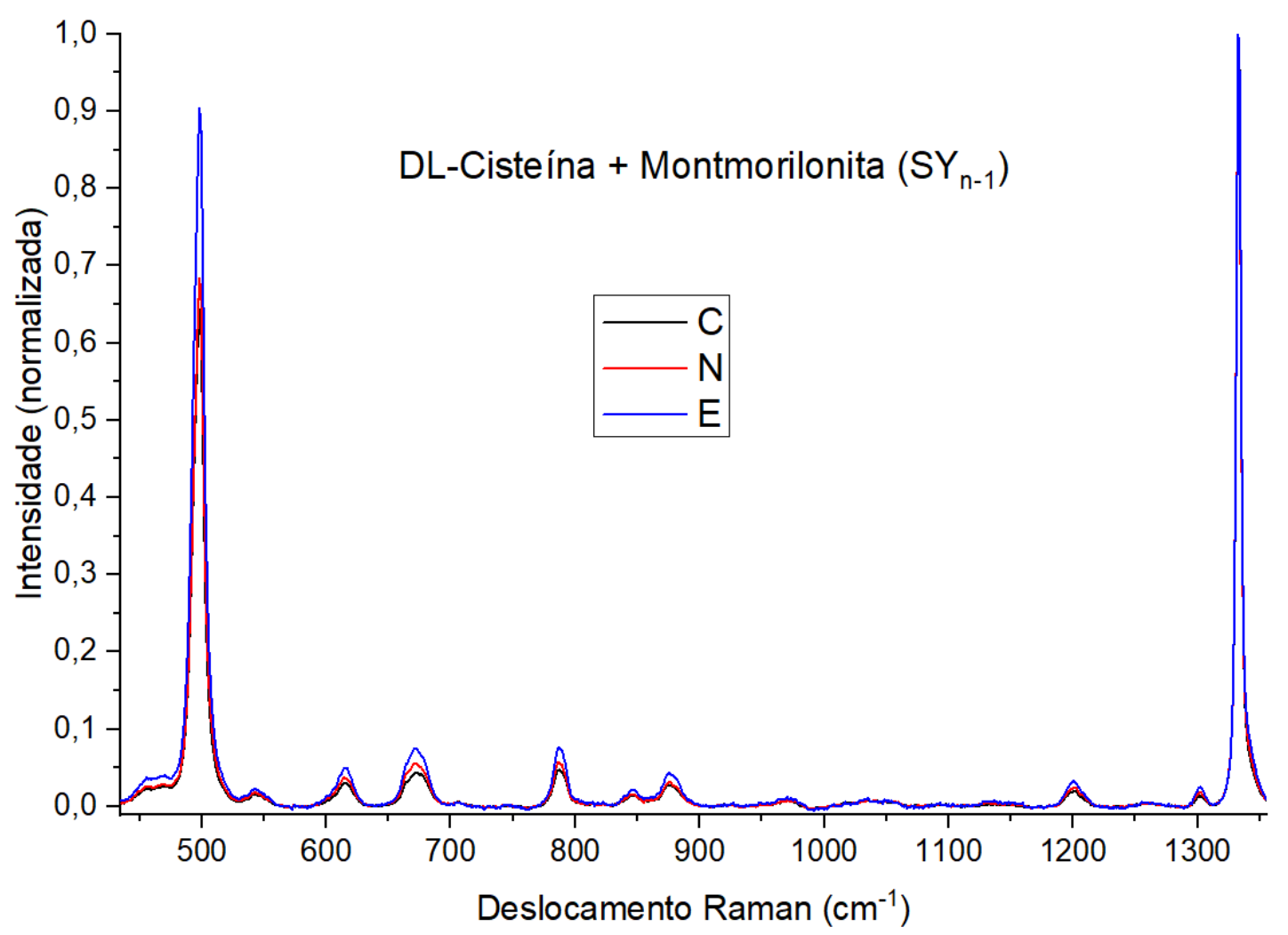

Figura 84 - Espectros Raman da DL-cisteína misturada com a argila montmorilonita nas 3 condições experimentais: exposta à radiação, não exposta à radiação e controle em Terra.

Fonte: Elaborada pela autora 


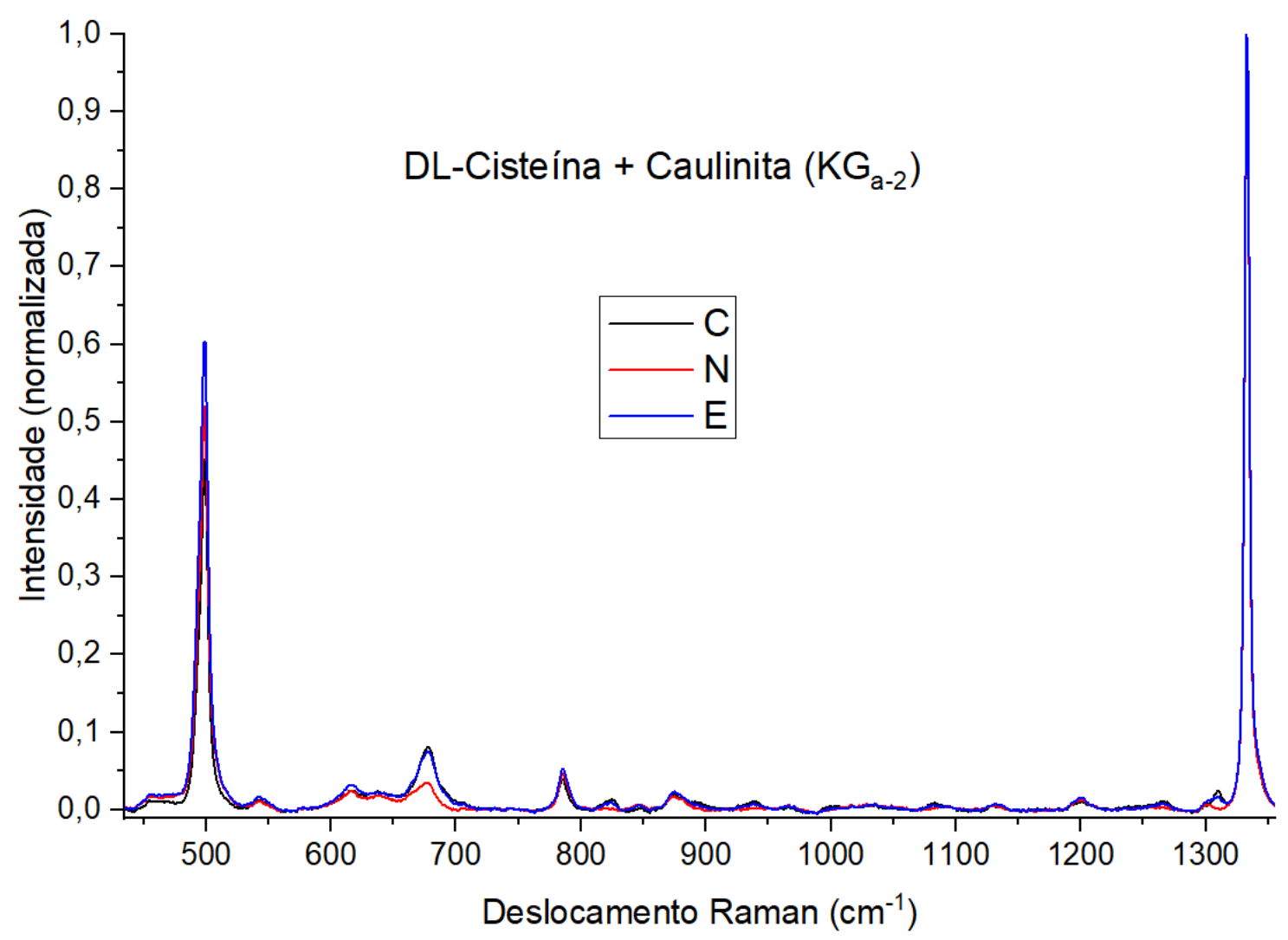

Figura 85 - Espectros Raman da DL-cisteína misturada com a argila caulinita nas 3 condições experimentais: exposta à radiação, não exposta à radiação e controle em Terra.

Fonte: Elaborada pela autora

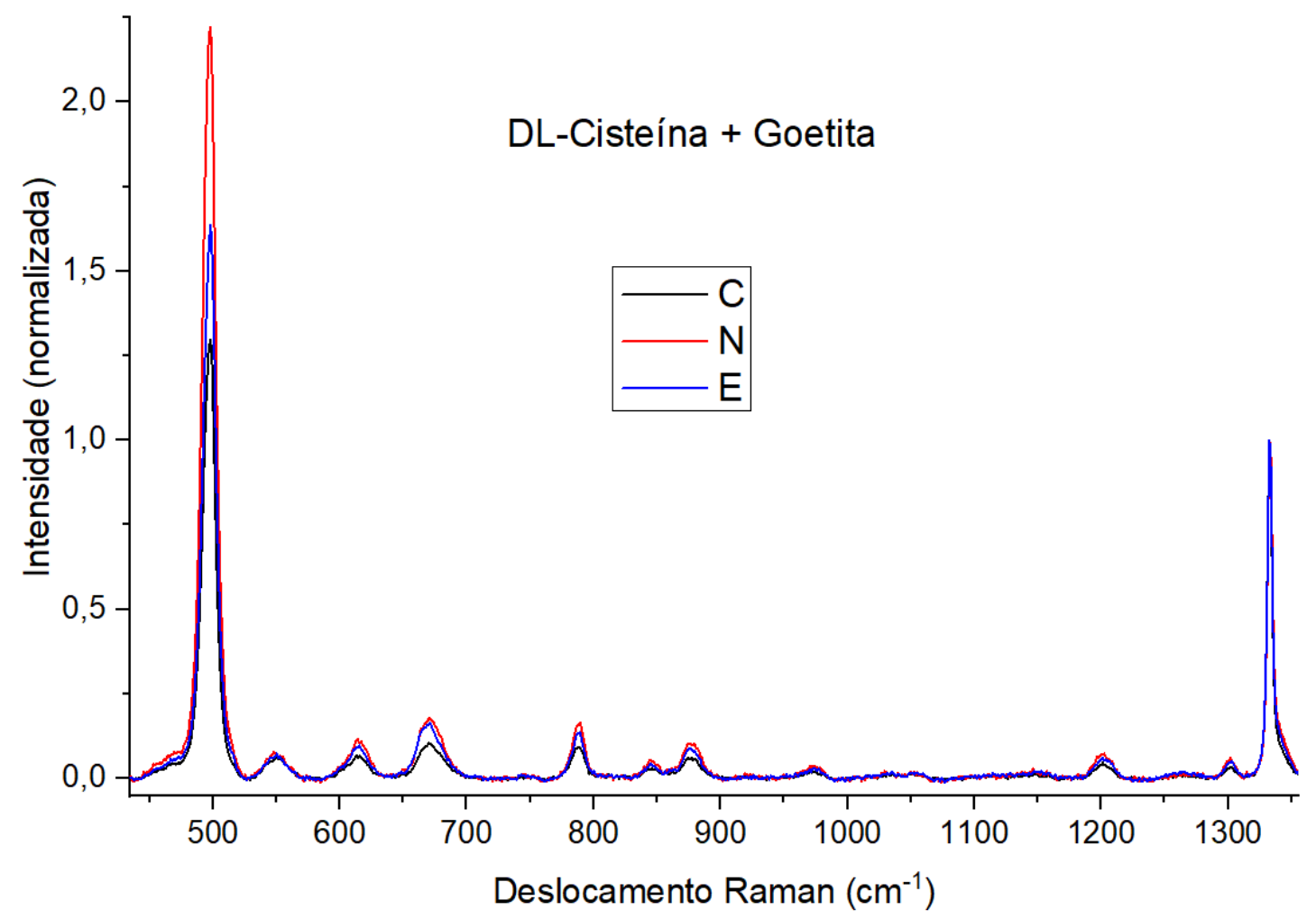

Figura 86 - Espectros Raman da DL-cisteína misturada com o hidroxi-oxido de ferro goetita nas 3 condições experimentais: exposta à radiação, não exposta à radiação e controle em Terra. 


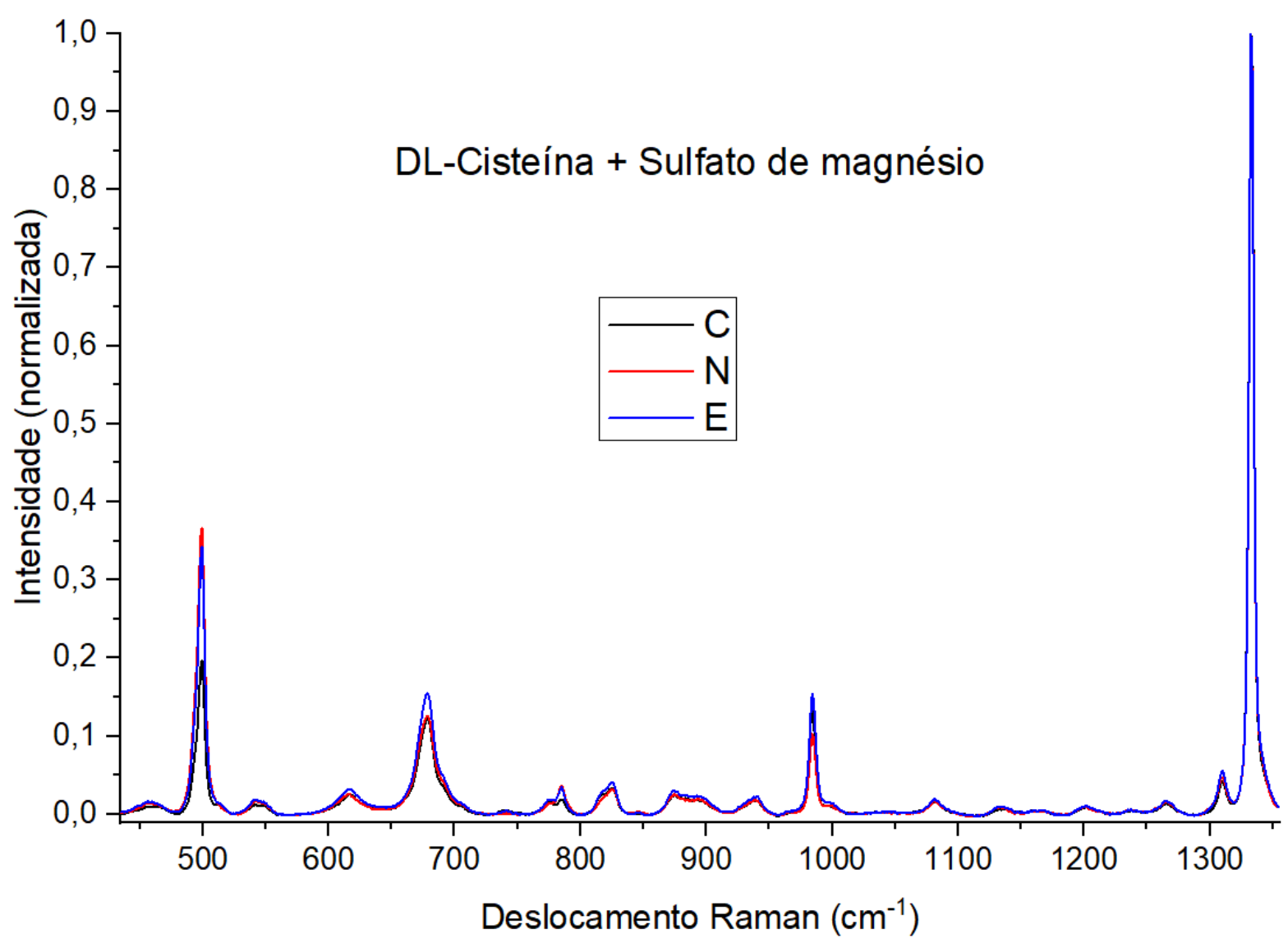

Figura 87 - Espectros Raman da DL-cisteína misturada com nas 3 condições experimentais: exposta à radiação, não exposta à radiação e controle em Terra.

Fonte: Elaborada pela autora 